\title{
Circulating excitation in the heart
}

Citation for published version (APA):

Allessie, M. A. (1977). Circulating excitation in the heart. [Doctoral Thesis, Maastricht University]. Rijksuniversiteit Limburg. https://doi.org/10.26481/dis.19770304ma

Document status and date:

Published: 01/01/1977

DOI:

10.26481/dis.19770304ma

Document Version:

Publisher's PDF, also known as Version of record

\section{Please check the document version of this publication:}

- A submitted manuscript is the version of the article upon submission and before peer-review. There can be important differences between the submitted version and the official published version of record.

People interested in the research are advised to contact the author for the final version of the publication, or visit the DOI to the publisher's website.

- The final author version and the galley proof are versions of the publication after peer review.

- The final published version features the final layout of the paper including the volume, issue and page numbers.

Link to publication

\footnotetext{
General rights rights.

- You may freely distribute the URL identifying the publication in the public portal. please follow below link for the End User Agreement:

www.umlib.nl/taverne-license

Take down policy

If you believe that this document breaches copyright please contact us at:

repository@maastrichtuniversity.nl

providing details and we will investigate your claim.
}

Copyright and moral rights for the publications made accessible in the public portal are retained by the authors and/or other copyright owners and it is a condition of accessing publications that users recognise and abide by the legal requirements associated with these

- Users may download and print one copy of any publication from the public portal for the purpose of private study or research.

- You may not further distribute the material or use it for any profit-making activity or commercial gain

If the publication is distributed under the terms of Article $25 \mathrm{fa}$ of the Dutch Copyright Act, indicated by the "Taverne" license above, 


\section{Circulating Excilation}

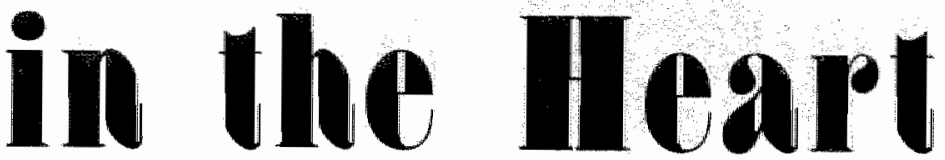

ACADEMISCH PROEFSCHRIFT

ter verkrijging van de graad van Doctor in

de Geneeskunde aan de Rijksuniversiteit Limburg,

op gezal van de Rector Magnificus Dr. H.A. Iiddens, Hoogleraar aan de Faculteit der Geneeskunde, volgens besluit van het college van Dekanen, in het openbaar te verdedigen in de Aula van de universiteit, Tongersestrat 53, Mastricht, op vrijäag 4 maxt 1977, des namiddags om 16.00 uur door

\section{Maurilius Inlonius ALLSSIE}

celjoren te cemert 

Dank-zij PAULA MARTIJN

MICEIEL 


\section{Voorwoord}

Het onderzoek, zoals beschreven in dit proefschrift, is niet het werk van éen man. De tijd dat een onderzoeker geheel zelfstandig vruchtbaar en grensverleggend onderzoek kon verrichten ijjkt, althans voor de biomedische wetenschappen grotendeels voorbij. Verdieping van ons inzicht in de vele facetten van de Geneeskunde kan in de meeste cevallen slechts door langdurige en moeizame arbeid worden bereikt. Vaak is hierbij een multi-disciplinaire benadering verelst. Bovendien worden de voor het onderzoek noodzakelijke technieken stoecs ingewikkelder, terwijl de hoeveelheid verkregen meetgegevens hiemee teminste evenremir toeneemt. Een en ander brengt met zich mee dat biomedisch onderzoek tegenwoordia bijna uitsluitend in groepsverband wordt verricht. De omschrijving van een proefschrift in het Academisch statuut als zijnde een geschrift dat het resultat is van onderzoek uitgevoerd door één persoon, dient daarom als een contradictio in terminis te worden beschouwd.

Gaarne wil ik dan ook van deze gelegenheid gebruik maken al diegenen te noe... men die direct of indirect hebben bijgedragen tot het tot stand komen van dit proefschrift.

Dit onderzoek is samen met dr. F.I.M. Bonke en mevrouw F.J.G. W1 lms-Schopman gedaan. Het is mijn vaste overtuiging dat zondex hun hulp en zonder de hechte teamgeest en onderlinge vriendschap, die sinds vele jaren tussen ons cileen bew staat, dit onderzoek vroegtijdig schipbreuk zou hebben geleden. Niet alleen hebben wij elkaar op een bijna perfecte wijze aangevuld en sterk wederzijds motiverend gewerkt, maar bovendien is deze samenwerking altija een bron wan grote vreugde voor mij geweest.

Dr. Bonke, beste vic, vlak voordat jezelf voor een jaar naor het tiysiologisch Laboratorium in Bern vertrok, wist je mij te interesseren voor jouw onderzoek. Als kundig organisator, haalde je me over het Eenomeen van de herhaalde ontladingen in de hartspier, war je toen juist op gestuit was, tijdens jouw afwezigheid te onderzoken. Dat is het begin geworden van een steeds groeiende samenwerking en een langdurige vriendschap die voor mij van grote betekenis zijn. Het lijkt haast onnodig te zeggen dat ik veel van je heb geleerd. Het vervult me 
met grote veldoening je vandaag als promotor te ontmoeten.

Mevrouw E.J.G. Whims-Schopman, beste Francien. Je hebt dit onderzoek van begin tot; elnde mede gedrager. Het felt dat je co-auteur bent van de drie publicaties, die de kern vormen van dit proefschrift, is hiervoor reeds voldoende bewijs. Ik ben je zeer veel dank verschuldigd voor het vele werk dat je in het kader van dit onderzoek hebt gedaan en met name voor de plezierige sfeer waarin we altija hebben samengewerkt.

Prof. ar. I. N. Bouman, geachte promotor. Jij hebt in het Fysiologisch Laboratorium van de Universiteit van Ansterdam de hartgroep opgericht die de voedingsbodem is geweest warop het onderzoek, dat de basis vormt van dit proefschrist, is gegroeld. Ook persoonlijk ben je van grote invloed geweest op mijn academische vorming. Vaak ben ik ondex de indruk gekomen van je grote draagkracht en briliante geest. Jouw grote interesse en verantwoordelijkheidsbesef voor het onderwijs hebben aanstekelijk op mij gewerkt. Jij was natuurlijk ook degene die voorstelde deze promotie in Maastricht te laten plaatsvinden; dit ondarks het feit dat het proefschrift bijna geheel in Amsterdam is bewerkt. Het is tekenend voor je wens anderen van jouw inspanningen te laten profiteren.

Dr. M.J. Janse en Prof. Dr. H.J.J. Wellens wil ik danken voor hun bereidwilligheid om als referenten op te treden. Eerstgenoemde ben ik bovendien veel dank versohuldiga voor de wijze warrop hilj tezamen met Drs. F.J.L. van Capelle mij heeft ingewija in ce geheimen van de door hen ontwikkelde 10-voudige microelectrode "borstel".

Prot. dr. rin. Boeles. W was, als voorzitter van de vakgroep Fysiologie wark binnen dit proefschrift tot stand is gekomen, de "stille kracht" op de achtergrond, die met volstrekt voorbijgaan aan eigenbelang, voor eenieder altijd het beste heeft nagestreefd. De gunstige omstandigheden waaronder ik dit onderzoek heb kunnen doen, zijn voor een groot deel door u gecreëerd.

Dr. T. Blangê,, beste Tuug. Je gewoonte om langzaam te spreken en lang na te denken is ook voor cit proefschrift van grote waarde gebleken. De grondgedachte van het "leading circle" model is tijdens discussies met jou ontstaan.

Andere leden van de hartgroep. De werkbesprekingen die we gedurende vele jaren wekelijks hebben gehouden, zijn voor mij van groot nut geweest. De gedetailleerde kritiek die ik daar heb mogen ondervinden, en de vaak heftige discussies, die daar werden gevoerd, hebben me steeds gedwongen de verkregen resultaten kritisch te bezien en objectief te beoordelen. 
Mej. C.E. Besselen, beste Eliy. Je hebt de moeilijke opgave om na het vertrek van Francien haar plaats in te nemen, op bewonderenswaralge wijze vervuda. Met name je grote zorg voor een voortarende aanvoer en distributie van het "Vakmanschap is Meesterschap" belovende elixir, heb lk altjja als een grote weldaad ondervonden.

De medewerkers van de electronische werkplaats (hoofd: A.A. Meyer) en de mechanische werkplaats (hoofd: A.W. Schreurs) ben ik veel dark verschuldigd voor de ontwikkeling van de nieuwe apparatuur die dit onderzoek mogelijk heeft gemaakt. ok ben ik dankbar voor hun onuitputtelijke geduld en begrip waamee zij, nadat ik door onoordeelkundig gebruik de veelal delicate apparatur geheel had ontregeld, cle ontstane schade in korte tijd weer wisten te reparexen.

Bebby van der Mars en Els Geurts hebben het meeste type-werk verricht. De ongeweltheid warmee zij tot het laatste moment de noodzakelijke vexanderingen in het manuscript hebben aangebracht was voor mij een grote steun.

Verder wil ik danken: de heer $\mathrm{A}$. Louwes, die zeer nauwgezet het fotografisch werk heeft verricht, de heren B.M. Hilgersom, M. Free en J. Riepen, op wie ik nooit tevergeefs een beroep heb gedaan, de heer J. Alkema en medewerkers voor de verzorging wan de proefdieren, de medewerkers van de bibliotheek van het Jan Swammerdan Instituut en van de Rijksuniversiteit Limburg die mij behulpzaam zijn geweest bij het verzamelen van de soms moeilijk te achterhalen literaturu, de heer $C$. Voskamp voor het ontwerp van de omsig, en de heer I. Meerstad voor de verzorging wan het drukwerk. 


\section{Contents}

KORTE INHOUD

CHAPTER II : THE HISTORY OF CIRCULATING EXCITATION II THE HEART

- early description of flutter and fibrillation

- focal imrulse formation versus circulating excitation wave

- the concept of circulating excitation

- circus movement in the atrium

- circus movement in the ventricles

- circus movement with the involvement of an accessory atrio-ventricular pathway

- circus movement in the atrio-ventricular node

- circus movement in the sino-atrial node MECHANISM OF TACHYCARDIA

- Introduction

- Methods

- preparation

- stimulation

- recording

- data processing

- Results

- induction of tachycardia

- rate and rhythm of the tachycardia

- pathway of the excitation wave during tachycardia

- termination of tachycaraia

- Discussion 
CHAPTER IV : THE ROLE OF NONUNITORM RECONERY OF EXCTTABTLIMY TN THE

OCCURRENCE OF UNIDTRECTIONAL BLOCK, AS STUDIED WITH MULTIPLE MICROELECTRODES

- Introduction

- Methods

- multiple microelectrode recordings

- measurements of spatial dispersion in the refractory period

- artificial introduction of differences in the refractory period

- Results

- multiple microelectrode recordings during the initiation of tachycaraia

- nonuniform recovery of excitability and unidirectional block of a premature impulse

- Discussion

- significance of dispersion of refractory period in the genesis of tachycardia and fibrillation

- Local conduction block as the center of circus movement

- aimensions of the site of local block as the decisive elements in the creation of xeentrant pathways

CHAPTER V : THE "LEADING CTRCLE" CONCEPT: A NEN MODEI OF" CTRCUS MOVEMENT IN CARDTAC PISSUE INTTHOUT THE INVOLVEMENT OF AN ANATOMICAL OBSTACLE

- Introduction 99

- Methods 100

- Results

- intracellular recordings from the center of $10 \%$ circus movement

- extracellular recoraings from the center of 105 circus movement

- the effect of carbanylcholine, tetrodotoxine, and temperature on circus movement tachycardia 
- Discussion

- the leading circle concept 111

- theoretical considerations or the leading 113 circle model

- changes in rate of leading circle tachycardia by alterations in electrophysiologic properties

- changes in aimensions of the leading circle

APPENDIX I: MICROMANIPULATOR WITE AN ELECTRODE DRIVER USED FOR MICROELECTRODE WORK

APPENDIX II: A CONCENTRICALLY AND RADTALLY ADJUSTABLE HOLDER FOR TEN MICROELECTRODES

The figures of Chapter 1 and 2 are reproduced with permission from the following works and journals:

Circulation Reseatch (figs. 1 and 2 of Chapter 1, ard figs. 19, 20, 21, 22, 23 , $27,28,29,30,31,32,33$, and 34 of chapter 2), Zeitschrift für Rationelle Medizin (Fig. 1 of Chapter 2), Transactions Royal Society of Canada (figs. 2 and 7 of Chapter 2), Carnegie Institution of Washington ( Laboratory at Tortugas (figs. 4 and 5), Journal of Physiology (figs. 6 and 8), British Medical Journal (fig. 9 ; the photograph of Mines was kindly provided by Prof. D.A. Rytand), Heart (figs. 10, 11, and 12), The Tohoku Journal of Experimental Medicine (figs. 13 and 16), The Mechanism and Graphic Registration of the Heart Beat, by T. Lewis, Shaw and Sons, London (fig. 14), American Heart Journal (Eig. 15). Amexican Journal of Physiology (figs. 17 and 18), Reentrant Arxhythmias, Mechanisms and Treatment, editor H.E. Kulbertus (figs. 24 and 25), European Journal of Caraiology (fig. 26), De atrium extrasystole, Thesis, by F.I.M. Bonke, Hollandia offset, 1968 (fig. 35). 
Part of the present thesis has already been published:

CHAPTER III: Allessie, M.A., Bonke, F.I.M., Schopman, F.J.G.: Circus movement in rabbit atrial muscle as a mechanism of tachycardia. Circ. Res. 33, 54-62, 1973

CHAPTER IV: Allessie, M.A., Bonke, F.I.M. "Schopman, F.J.G.: Circus movement in rabbit atrial muscle as a mechanism of tachycardia. II. The role of nonuniform recovery of excitability in the occurrence of unidirectional block, as studied with multiple microelectrode. Circ. Res. 39, 168-177, 1976

CHAPTER V : Allessie, M.A., Bonke, F.I.M., Schopman, F.J.G.:

Circus movement in rabbit atrial muscle as a mechanism of tachycardia. III. The "leading circle" concept: a new modej of circus movement in cardiac tissue without the involvement of an anatomical obstacle. Circ. Res. 40, 000-000, 1977

Appendix I': Schreurs, A.W., Meyer, A.A., Bouman, L.N., Bonke, F.I.M.: Micromanipulator with an electrode driver used for microelectrode work. Pfluegers Arch. 346, 163-166, 1974

Appendix II: Schreurs, A.W., Selij, A.P.L., Allessie, M.A., Bonke, F.I.M.: A concentrically and radially adjustable holder for ten milcroelectrodes. Pfluegers Arch. 346, 167-170, 1974 
Dit hele proefschrift draalt om een verschijnsel, cirkelgeleiding of reentry genaama. Hiermee wordt de situatie aangeduid dat de electrische impuls die het startsignaal voor de hartslag is, ergens in het hart in een vicieuze cirkelgang "gevangen" is. Onder normale omstandigheden, waarin het hart met bij voorbeeld 60 slagen per minuut klopt, wordt er elke seconde door een groepje gespecialiseerde hartcellen (de sinusknoop) een zwak electrisch strompje gegenereerd. Dit electrische stroompje breidt zich snel naar alle kanten over het hele hart ult, om tenslotte, zodra de grenzen van het hart bereikt zijn, weer uit te doven. Op deze manier worden alle hartspiercellen kort na elkaar geactiveerd met als gevolg dat het haxt zich samentrekt.

Ex kunnen zich echter ook stoormissen in dit normale ritme voordoen. Het hart kan bij voorbeeld plotseling zonder schijnbare reden, veel te snel gaan kloppen. Men spreekt dan van een tachycardie. ook is het mogelijk dat de hartcellen niet alleen in een hoog tempo geactiveerd worden, maar dat tevens de synchronisatie tussen de cellen verloren is gegaan (fibrilleren). Hoewel hierbij ledere cel afzonderlijk een hoge activiteit vertoont, staat het hart dan als geheel stil en wordt er geen bloed meer uitgepompt. Het is mogelijk dat in beide gevallen cirkelgeleiding een belangrijke rol speelt. In plaats van aan de grenzen van het hart uit te doven, wordt de impuls in een cirkelpad gevangen warin het in principe eindeloos kan blijven rondeirkelen. De hartfrequentie wordt dan niet meer bepald dooi de ontladingsfrequentie van de sinusknoop, max door de tifd die de impuls nodig heeft dit cirkelpad ërn keer te doorlopen. Aangezien in het algemeen deze omlooptija veel korter is dan de normale pauze tussen twee hartslagen, is het hoge ritme van het hart hiermee verklaard.

In hoofdstuk 2 wordt een overzicht gegeven van de onderzoekingen welke door anderen in de loop der tija over het fenomeen wan de cirkelgeleiding zijn gedaan. In hoofastuk 3, 4 en 5 wordt het eigen onderzoek beschreven, waarin is getracht cirkelgeleiding in de hartspier rechtstreeks aan te tonen. Het bleek mogelijk in een geisoleerd stukje van de linker hartboezem van het konijn, door het opwekken van één enkele goed geplaatste extra hartslag (extrasystole), expeximenteel periodes van tachycaraie te veroorzaken. Door op zeer veell plaatsen in dit preparaat de electrische activiteit te meten, kon het electrische activatiepatroon van de hartspier nauweurig in kaart worden gebracht. Hierbij werd gevonden dat tijdens het langzame, normale ritme de impuls zich naar alle kanten uitbreidde; een der- 
gelijk radiair activatiepatroon is te vergelijken met de golffronten die ontstaan als we een steen in het water gooien. Tijdens de aanval van tachycardie daarentegen was van zulk een radiaire vooxtgeleiding geen sprake meer. Duidelijk kon woxden aangetoond dat in plates daarvan de impuls in een klein gedeelte van de hartspier rondcirkelde. De verkregen activatiepatronen tijaens tachycardie vertoonden veel gelijkenis met de bewegingen in een araaikolk (zie bij voorbeeld de kart zoals weergegeven op de omslag).

Deze cirkelgeleiding kont tot stand doordat de extrasystole op een zodaniae plats en op een dusdanig moment ontstaat of wordt opgewekt, dat de imouls van deze extrasystole niet normal over het hart kan worden voortgeleid; de voortgeleiding is in één richting geblokkeerd (uni-directioneel blok). Wanneer de electrische impuls zich vervolgens zodanig in het hart voortplant dat via een onweg dit blokgebied alsnog geactiveerd wordt, dan is het mogelijk dat het qebied waar de impuls is ontstaan voor een tweede keer van de andere kant af tot ontlading wordt gebracht (re-entry). Hiermee heeft de impuls een volledige cirkel afqelead en kan onder bepalde omstandigheden in dit cirkelpad blijven rondaraaier. Uit ons onderzoek is komen vast te staan dat ook in een betrekkelijk klein gebied (+ $30 \mathrm{~mm}^{2}$ ) van de harttspier cirkelgeleiding kan optreden.

Vervolgens is in hoofdstuk 4 nagegaan welke rol de refractaire periode speel.t bij het ontstaan van een dergelijke cirkelgeleiding. Een belangrijke eigenschap van hartcelden is, dat zij, na iedere activatie, enige tija niet opnieuw geprikkeld kumnen worden. De tijd, die de cellen nodig hebben om hun prikkelbaarheid weer te herstellen (refractaire periode), is niet overal in het hart precies ge$1 \mathrm{jjk}$. Om te onderzoken of er een causal verband bestaat tussen deze locale versckillen en het optreden van cirkelgeleiding, werden ook de refractaire periodes fin kaart gebracht. Op deze manier kon de wijze van ontstaan van cirkelqeleiding woxder vergeleken met de verdeling van de refractaire pexiodes over de hartspier. Uit deze experimenten bleek dat uni-directionele geleiding - een eerste voorwarde voor het ontstaan van cirkelbeweging - reeds kon optreden ten gevolge van relatief kleine plaatselijke verschillen in refractaire periode. Indien on de grens van twee gebieden met een verschillende refractaire periode een vroege extrasystole wordt opgewekt, wordt de impuls uitsluitend voortgeleid in de richting waarin de refractaire periode kort is. In andere richtingen, waar de refractaire periode van langere duur is, wordt de geleiding van de impuls geblokkeerd, ondat op het moment dat de extrasystole optreedt, de prikkelbaarheid ter platse nog niet vol- 
doende hersteld 1 .

In hoofdstuk 5 tenslotte wordt beschreven wat er gebeurt in het centrum van de cirkelgeleiding. Met behulp van microelectrodes werd het gedrag van induiduele cellen in het "oog" van de cirkeltachycardie onderzocht. Met name door de resultaten van deze laatste experimenten kon een model worden opgesteld dat cirkelgeleiding in de hartspier beschrijft zonder dat hierbij een depreformeerd (anatomisch bepald) pad is betrokken. Met dit model kan het gedrag van dergelijke cirkeltachycardieën onder een groot aantal omstandigheden worden voorspeld. Dit schept de mogelijkheid tachycardieën, zoals die bij patienten wook komen, te verqelijken met de in dit proefschrift beschreven cirkeltachycardie. 


\section{Chapter 1}

\section{Introduction}

Some years ago, shortly after I entered the Department of Physiology of the University of Amsterdam, for purpose of introduction, I was invited to attend an experiment carried out by Dr. Bonke and Bouman. At that time they were involved in a study on the effect of early premature beats on the normal rhythm of the sino-atrial node. Using the spontaneously beating isolated right atxium of the rabbit, they had sometimes observed that the induction of an early premature stimulus, instead of being followed by a single premature beat, evoked one or more non-stimulated extra beats. In the figure below, which is taken from their publication (BONKE, BOUMAN and SCHOPMAN, 1971), an example of this phenomenon is given.

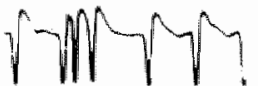

A

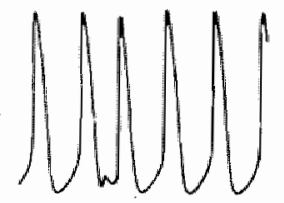

B

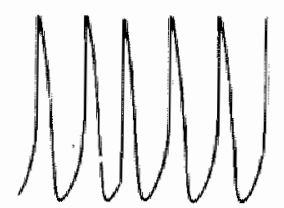

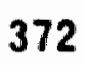

372

372
438 29

367

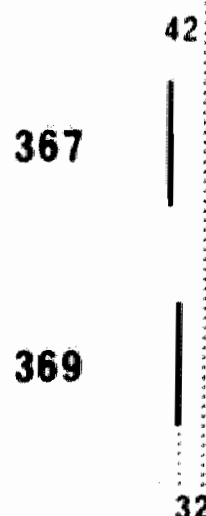

375

373

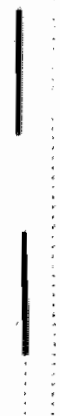

44

38

$\Omega$

FIGURE 1. Recording of a spontaneousty beating right atwith of the rabbit. upper trace: etectrograin. widde and lower tmaces: action potentials of two impaled fibers of the stroatrat nold. in the right part of the figure the intervals between the various beats are giver together with the onduotion

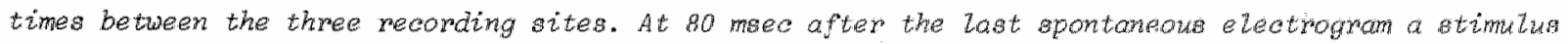

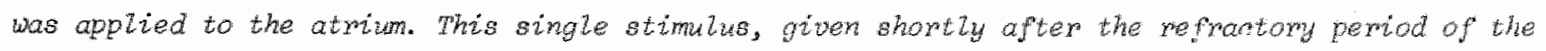
atrium, was followed by two atmial dischanges with an intemal of 98 and 134 mbec reapectively. Exapt for a smald eleatrotonie hump in fiber A, the early premature beat Failed to wathe the impated fiben 
A reentrant mechanism in the sinus node was considered to be the most likeIy mechanism underlying these rapid spontaneous discharges. A little earlier HAN, MALOZZI and MOE (1968) had provided evidence for this hypothesis. However, the possibility that the extra non-stimulated beats dia not originate in the sinus node, but instead were generated in the atrial myocardium, could not be ruled dut completely. The experiment for which I was invited was designed to test this matter. The idea was to repeat the experiment in isolated segments of the left atrium. Such an experiment was expected to yield negative results, since it was considered rather unikely that in the absence of the sinus node, a small piece of ordinary atrial muscie, which normally did not show any tendency of spontaneous activity, would staxt to generate impulses merely because of the induction of a single premature beat.

However, it turned out to be completely different. Even in a very small piece of ordinary atrial muscle the induction of a single stimulus of short duration and physiological strength (1 msec and $4 \mathrm{x}$ threshold, respectively) indeed could be the trigger for rapid repetitive activity. In figure 2 the original tracings as published by BONKE, BOUMAN and SCHOPMAN in their 1971 paper are reproduced.
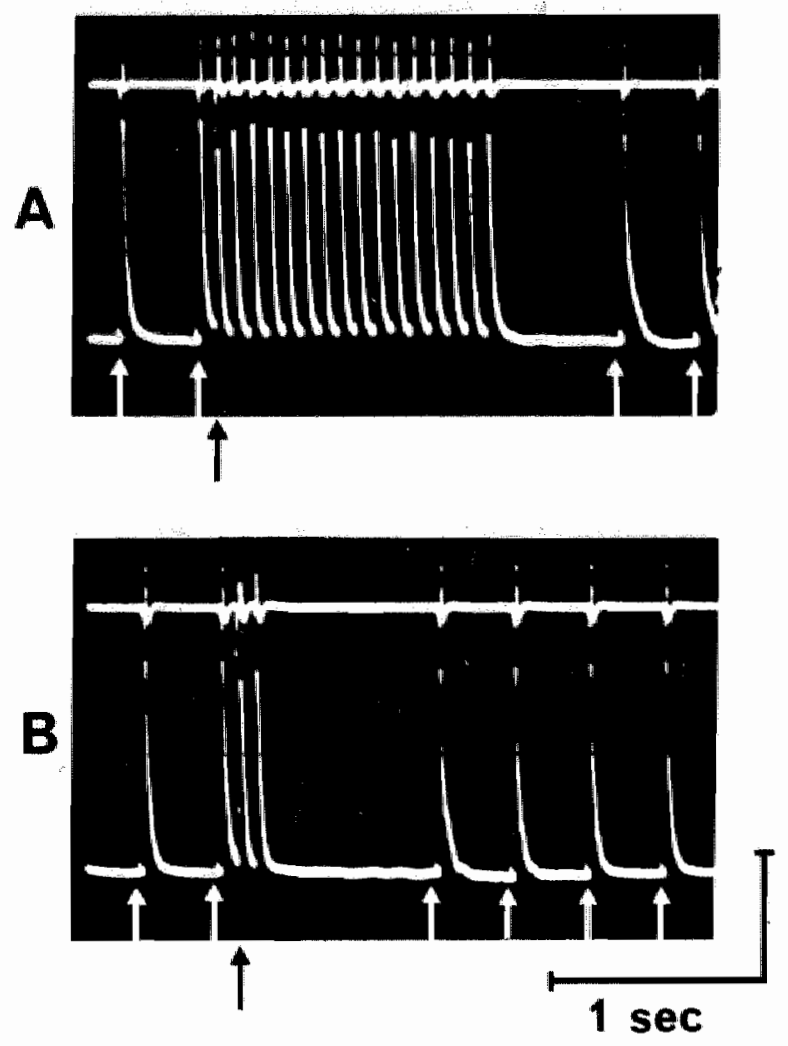

FIGURE 2. Recondrings of a tefe atrial prepara thon of the mabit. Upper thack: surface electrogram. Lower trace: transmembrane potertitat. White arrows indicate the baste stimet. and the biack armo indicate the extrat stwmlus. In $A$ the extra stimutus is followed by $a$ senies of 15 repeated atriat discharges; in $B$ the premature beat is folmowed by only one atmial discharge. Calibration was 50 mo and 1000 msec. 
This fortuitous observation which, as appeared later had already been described in a more general way (WEST and LANDA, 1962), was the starting point of this thesis. Initially the question was relatively simple: was this abnormal impulse formation or a reentrant mechanism? In chapter 3, I describe the way we tackled this problem and how we were able to demonstrate that the paroxysms of tachycardia were caused by a circus movement of the impulse. In chapter 4 detailed information is given about the phenomena occurring at the time of indiation of tachycardia. These data were acquired by combining multiple microelectrode recordings and measurements of local refractory periods. In this way it could be ascertained that spatial differences in refractory periods were responsible for the occurrence of unidirectional block during the propagation of the premature beat. In the last chaptex of this thesis (chapter 5), a new model of circulating excitation is presented, in which a central anatomic obstacle essential for most other models of circus movement - is no longer required. This "leading circle" concept is based on intracellular and extracellular measurements from the center of the circulating activation wave. With this model the behaviour of circus movement tachycardia can be predicted under various circumstances. Preceding these chapters, describing our own experimental work, chapter 2 reviews the studies by others, who have largely contributed to our present understanding of circulating excitation in the heart. This review does not pretend to be complete. It reflects my personal view on the history of circus movement in the heart.

\section{REFERENCES}

Bonke, F.I.M., Bouman, L.N., Schopman, F.J.G.: Effect on an early atrial premature beat on activity of the sinoatrial node and atrial rhythm in the rabbit. Circ. Res. 29: 704-715, 1971.

Han, J., Malozzi, A.M., Moe, G.K.: Sinoatrial reciprocation in the isolated rabbit heart. Circ, Res. 22: 355-362, 1968.

West, T.C., Landa, J.F.: Minimal mass required for induction of a sustained arrhythmia in isolated atrial segments. Am. J. Physiol. 202: 232-236, 1962. 


\section{,}




\section{Chapler:}

The memony of the mediod profession is short. One usee the knowledge or the remedies with thankfulness and neglects to encuire how they were obtained. Arthur R. Cushy (1911)

\section{THE HISTORY OF CIRCULATING EXCITATION IN THE HEART}

\section{Eaxly description of fluttex and fibriliation}

It is likely that the phenomenon of a fibrillating heart was rather familiar already to primitive mankind, as there must have been ample opportunity to observe this arrhythmia directly from the dying heart in slaughtered animals. How ever, it was not until the seventeenth century that the first written report of what might have been atrial flutter or fibrillation appeared. In his famous "Excercitatio anatomica de motu cordis et sanguinis in animalibus", WILIIAM HARVEY wrote in 1628: "But I have also from time to time noticed that, after the heart proper and even its right auricle were ceasing to beat and appeared on the point of death, an obscure movement/undulation/palpitation had clearly continued in the right auricular blood itself". About the exact nature of this arrhythmia one can only speculate, particularly because HARVEY added: "Inded, one may wonder if the blood or spirit earlier has that obscure throbbing within it which I thought it continved to have after death, and if we may say that life begins with that throbbing".

A more clear description of what now is known as ventricular fibrillation is given by ERICHSEN in 1842, describing "tremulous motion" and "tumultuous" action of the heart following ligation of coronary atteries in the dog:

Systematic experimental production and registration of ventricular fibrillation were introduced by HOFFA and LUDWIG in 1850. They found that the anplication of strong faradic current to the ventricles of the dod and the rabbit, invariably resulted in fibrillation. "Wenn eine sehr kräftge elektrische wirkung ein recht reizbares Herz triff.... geraht das Herz in ausseroxdentilich rasche, ganz unregelmässige Bewegungen von sehr gexinger Intensität. Die Unregelmässigkeit dieser Bewegungen entsteht dadurch, dass die einzelnen anatomischen Elemente sich aus ihren Beziehungen zu einander lösen und die Gleichzejtigkeit ihrer kon- 
traktion aufgeben; hiexdurch exzeugt sich in Beziehung auf Rhythmus und Intensitat ein Wirrwar, wie Thnen annähernd Fig. 19 (see Fig. 1 of this chapter) veranschaulicht, welche von einem kaninchenherzen selbst gezelchnet ist. Um einen ungefahren Begriff von der Beschleunigung der Bewegung $z u$ geben, exwähnen wit das hier belgegebene Kurvenstück, welches 8,34 Sekunden umfasst, 84 Schläge enthalt, so dass auf die Minute 604 Herzschläge kommen würden... Diese Bewegungen uberdauern immer den Reiz, und zwar um so längex je anhaltender er eingewirkt hatte". Figure 1 shows the lever system they used for registration of the mechanical activity of the heart together with their first record of ventricular fibrillation.

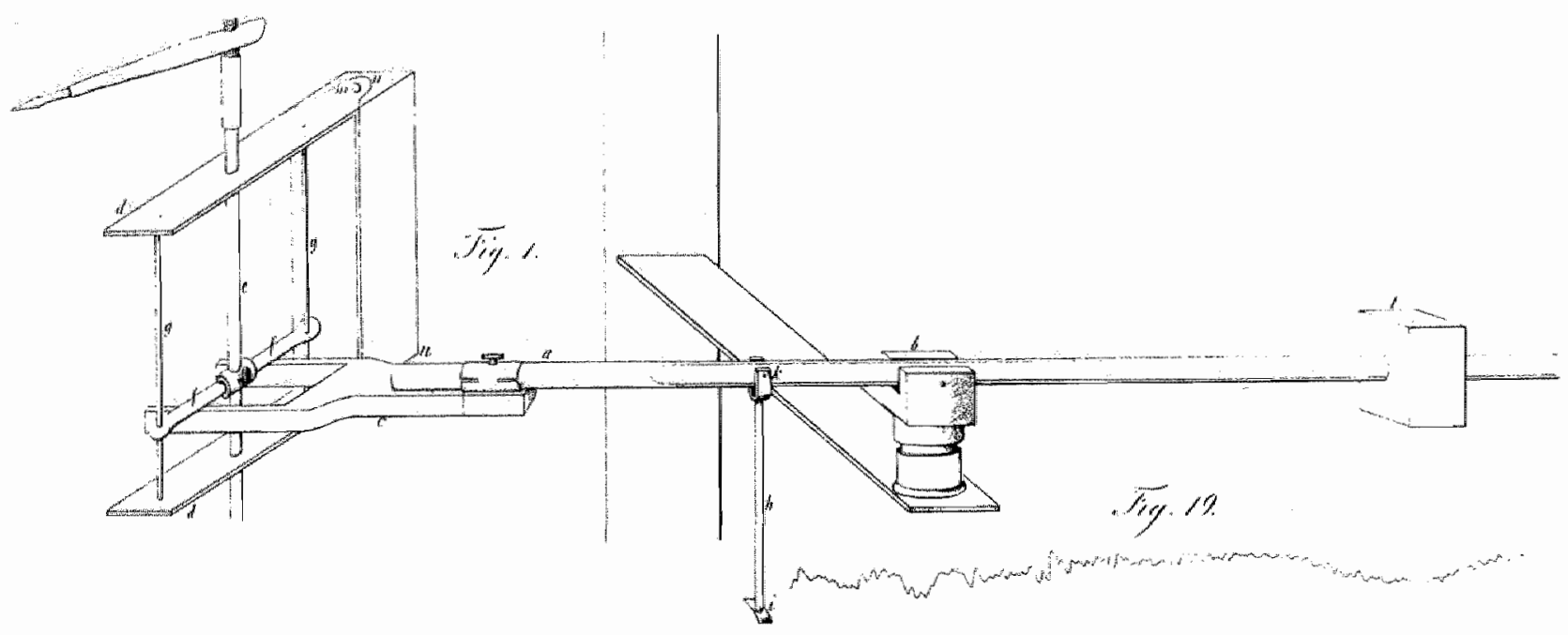

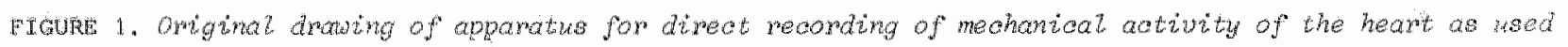

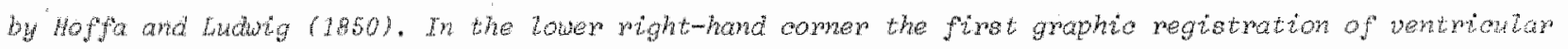
Nibriltation is shown, the ouve, which is taken from a rabbit heart, represents 8,3 seconds. Fibritiawion was thalued by atrong foradio stimulation.

From this time on the condition in question was studied by various investigators and in "1889 McWrLLIAM summarizes its general characteristics as follows: "The normal beat is at once abolished, and the ventricles are thrown into a tumultuous state of guick, irregular, twitching action; at the same time there is a great fall in blood pressure. The ventricles become distended with blood, as the rapid guivering movements of theix walls is wholly insufficient to expel their contents. The muscular action partakes of the nature of an arxhythmic, incoordinated and rapidly-repeated contraction of the various muscular bundles. Some bundles are in a 
state of contraction while other bundles are relaxed and so instead of a coordinated contraction leading to a definite narrowing of the ventricular cavity. there occurs an irregular and complicated arrhythic oscillation of the ventricular walls which remain in a position of diastole. This condition is very persistert, and it is easy to kill a dog by applying a faradic current to the ventricles... The cardiac pump is thrown out of gear, and the last of its vital. energy is dissipated in a violent and prolonged turmoll of fruitiess activity in the ventricular walls". It is amazing to realize that this early description and explanation of what in that time was designated by various names as Herz delirium, Delirium cordis, Fibrillar contraction. Intervermiform movenent, Fremissement fibrillaire, etc., is not far from what we know today about the mechanism of Eibrilation. It illustrates our inability to analyze such a complex phenomenon.

After fibrillation of the atria was described by VULPIAN in 1874 , some years later MCWILIIAM (1887) compared the effects of faradic stimulation of the ventricles and the atria. He found that, in the auricles, faradic stimulation caused atrial flutter rather than fibrillation, a difference which he explained by the simpler architecture of the atria: "The application of the current sets the auricles into a rapid flutter, the rapidity of which largely depends upon the excitability of the auricular tissue and the strength of current employed. The movements are regular; they seem to consist of a sexies of contractions originating in the stimulated area and thence spreading ovex the rest of the tissue. The movement does not show any distinct sign of incoordination; it looks like a rapid series of contraction waves passing over the auricular walls. "Tho ditererence between this appearance and that seen in the ventricles probably depends on the simpler structure and arrangements obtaining in the auricles". He also noticcd that the phenomenon of fibrillar contraction is much more readily induced and much more persistent in the higher mammals than in the lower forms (MchILLIAM, $1889)$.

(GAREY (1914) correlated this difference between hearts of different species with the size and the form of the tissues involved. He concluded: "The ease with which the fibrillary contractions take place is inversely proportional to the mass of fibrillating tissue.... fibrillary contractions are not depenclent upon impulses initiated in any given area, even if the area be the one from which the process was started, but is a process in which the whole tissue mass 
1 involved. It is dependent upon the integrity of a considerable mass of tissue, and subdivision of this mass into smaller bits brings all of the tissue out of the state of incoordinated contractions, the pieces either coming to rest or beating independently with a perfect rhythm".

In the same year MrNes (1914) discovered that not only faradic stimulation of the heart can induce fibrillation, but that under some conditions a single stimulus of very brief duxation, given shortly after the end of the refractory phase, may already be sufficient to induce fibrillation, suggesting that fibxillation may be started by a single ventricular extrasystole of intrinsic origin. "It was found that a single tap of the Morse key if properly timed woula start fibriliation which would persist for a time which varied in different cases.... the point of interest is that the stimulus employed would never cause fibrillation unless it was set at a certain critical instant". Figure 2 illustrates this phenomenon. In panel A the first stimulus (indicated by a white dot superimposed on the tracing) falls within the refractory phase and does not influence the rhythm. The next stimulus, coming a little later in the cycle, set up fibrillation which persists for a certain length of time and then suddenly ceases. In panel B it is seen that stimuli coming later than the critical moment needed for the production of fibrillation merely induce extrasystoles. Comparison of the effect of the first and the last stimulus indicates that the critical moment for the production of fibrillation is immediately aftex the end of the refractory phase.

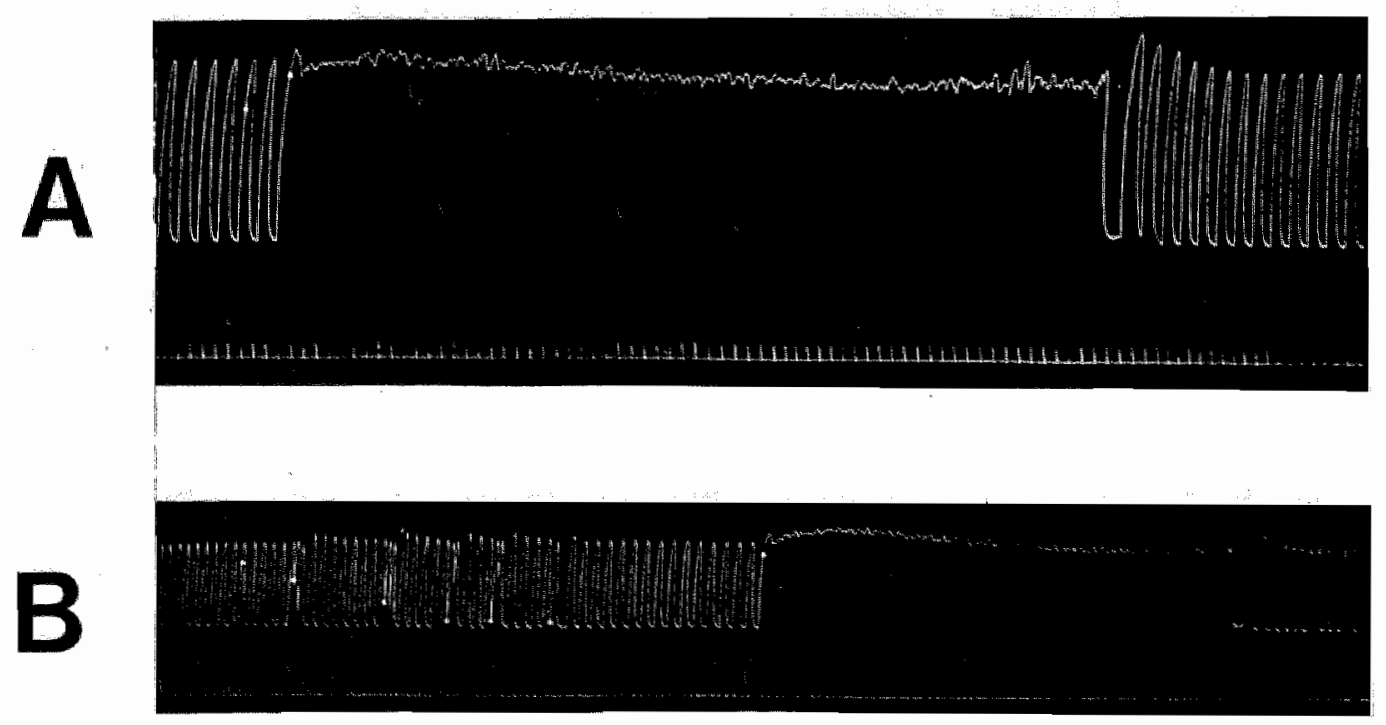

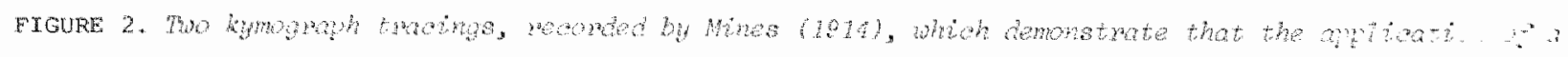

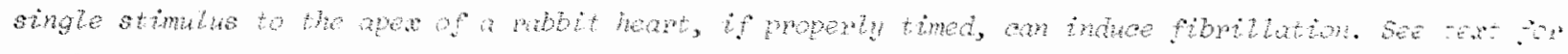
huther explanation 


\section{Focal impulse formation versus circulating excitation wave}

Over the years, two alternative hypotheses have been developed for the explanation of tachycardia and fibrillation: (1) Abnormal (enhanced) imolise formation, (2) Circus movement of the impulse. For many years there has been an intense discussion between groups of investigators, each advocating one of both theories. Without any justification it was thought that the two concepts were mutually exclusive. Now there is evidence that each of the two hypotheses has its own right. In fact, there are relatively few arxhythmias occurring in man where the cardiologist of today can decide with certainty which mechanism is involved. This lack of knowledge about the properties and behaviour of the underlying mechanisms is the main reason that the prevention and treatment of clinical. armythmias is still largely based on empirical grounds.

In this review I shall confine myself to those studies which give direct arguments in favour of the circus movement hypothesis. However, I want to emphasize that this should not be considered as argument against the altermative hyoothesis of enhanced automaticity. It will greatly depend on the experimental circumstances or clinical conditions which mechanism is involved.

\section{The concept of circulating excitation}

The first, rather premature thoughts about a reentrant mechanism as the cause of tachycardia and Eibrillation can be found in an article by MctILLTAM published in 1887. There, as an alternative for the earlier proposed possibjity of enhanced automaticity he wrote: "For apart from the possibility of rapid spontaneous discharges of energy by the muscular fibers, there seems to be another probable cause of continued and rapid movemert. The peristaltic contraction travelling along such a structure as that of the ventricular wall must reach adjacent muscle bundles at different points of time, and since these bundles are connected with one another by anastomosing branches the contraction would naturrally be propagated from one contracting fiber to another over which the contraction wave had already passed.... Hence the movement would tend to go on until the excitability of the muscular tissue had been lowered, so that it failed to respond with a rapid series of contractions".

However, with these ideas McWILIAM was far ahead of his time, and consequently 
this ealy concept of circulating excitation found no echo among other contemporary investigators. Rediscovery of the idea of a circulating impulse came from a rather unexpected side. It was the biologist MAYER, studying the nature of rhythrical pulsation of the jelly-fish, who re-aroused the interest for this phenomenon. In 1906 he found that a strip of paralyzed subumbrella tissue of soyphomedusa cut in the shape of a ring, of closed circuit, will pulsate rhythmically again, provided a contraction-wave be once started in the circuit.
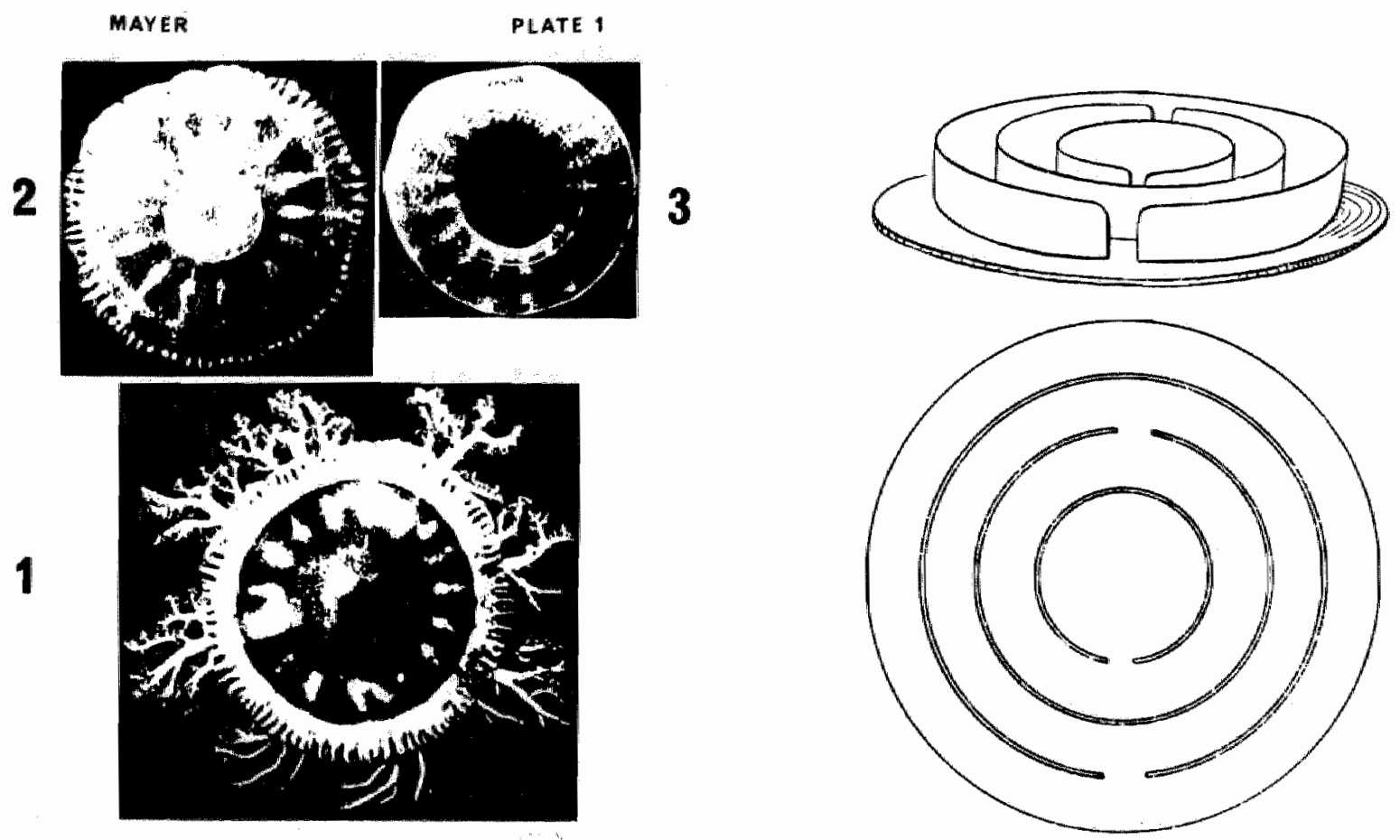

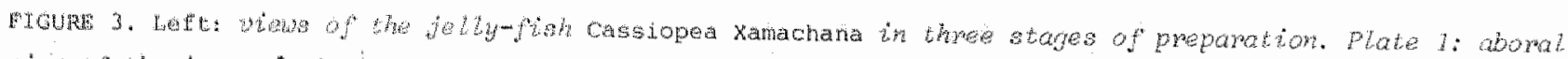

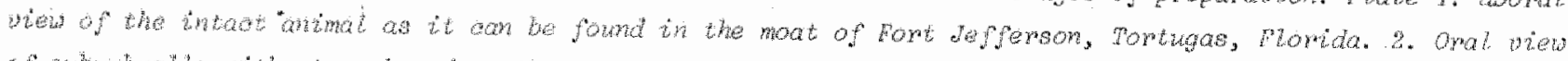

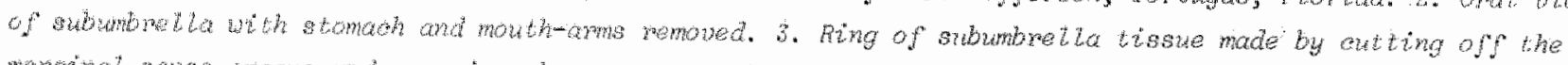

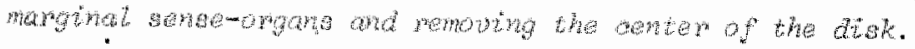

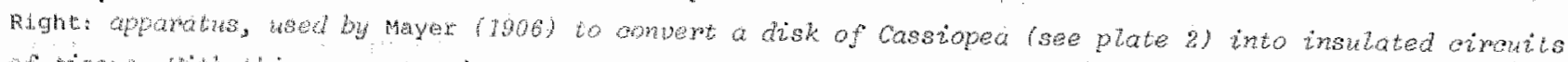

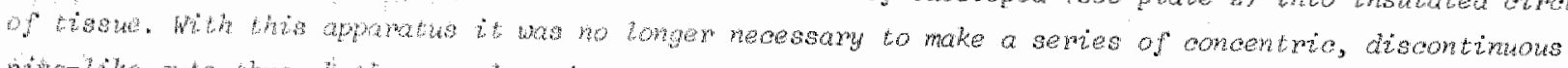

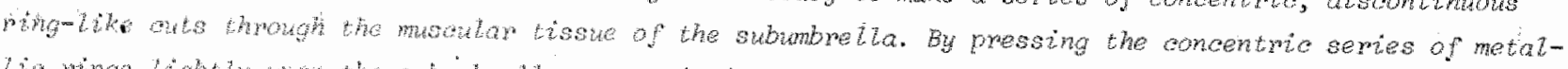

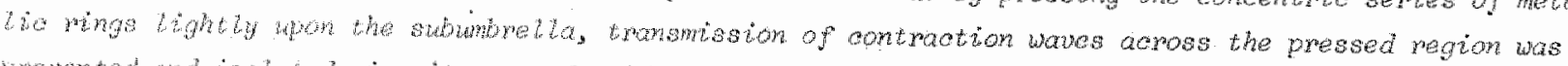

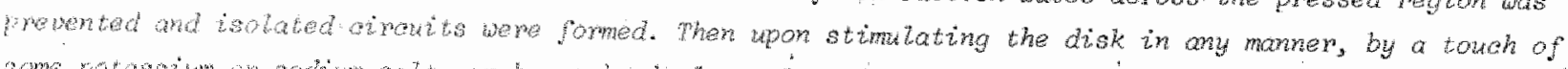

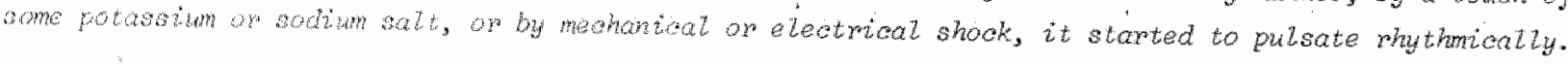

"If we cut off the marginal sense-organs of the scyphomedusa Cassiopea, the disk becones paralyzed and does not pulsate in sea-water. The disk will pulsate in sea-vater, however, if we make either a single ring or a series of concentric 
broken-ring-like cuts through the muscular tissue of the subumbrella. Then upon momentarily stimulating the disk in any manner, it suddenly springs into rapia, rhythmical pulsation so reqular and sustained as to recall the movement of clockwork". Figure 3 shows the jelly-fish and the ring of subumbella tissue together with the apparatus, consisting of a concentric series of metalif rings, which he used to form circuits by pressing lightly upon the subumbrella. In 1908 MAYAR demonstrated that the above described rhythmical activity was due to a single contraction-wave which continuously circulated around the ring. "inis single wave going constantly in one direction around the circuit may maintain itself for days travelling at a uniform rate. The circuit must, however, be long enough to allow each point to rest for an appreciable interval of time before the return of the wave. The wave is actually "trapped" in the circult and must constantly drive onward through the tissue. The point which was stimulated and fxom which the con traction-wave first arises is of no more importance in maintaining the rhythmical movement than is any other point of the ring....the wave is not reinforced and sent forth anew every time it returns to its place of origin, but is maintained by each and every part of the ring in succession as it passes". "The Latter staw tement he proved by insulating the point where the wave was originated from the rest of the ring. This intervention did not result in termination of the circus movement but on the contrary the wave continued unhindered through the circuit (see Fig. 4).

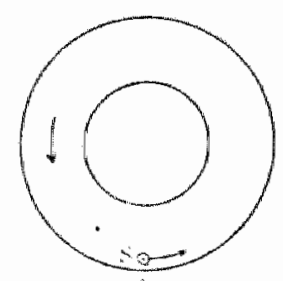

A
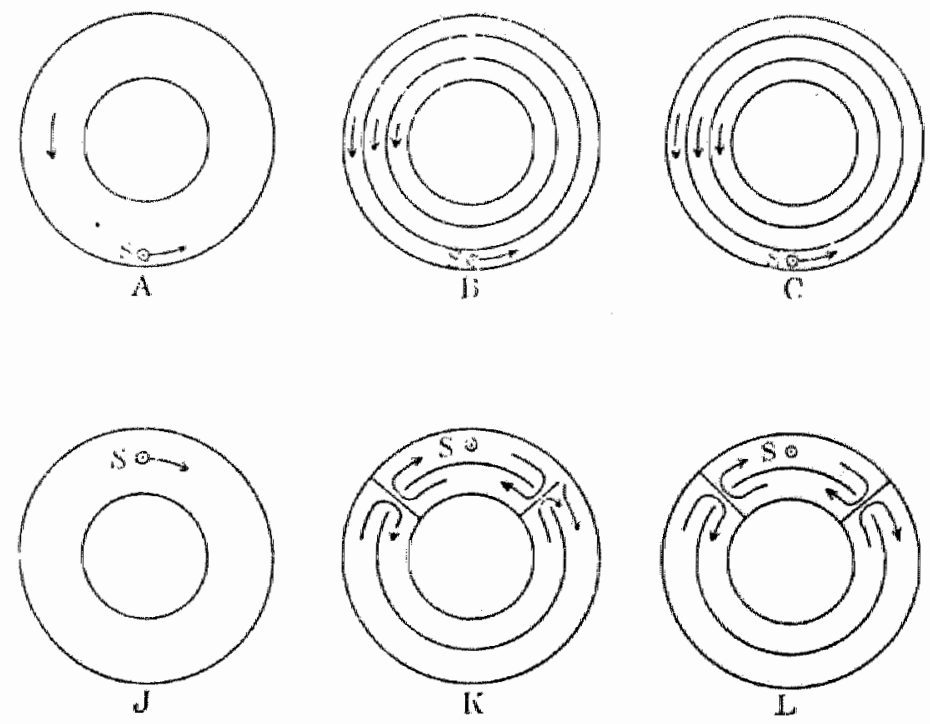

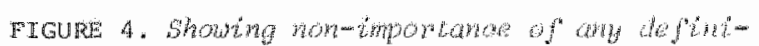

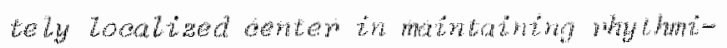
cal pulsation (Mayer, 1908). The puthe of stimulation where the entrabled otmati was inttiated is indicated by S. In panels AC a singte broad ming is dinided by tho ammitan whe into three septrate minge. yat the two thmer atroles which ane completely isolated from the point s remain in austathed puloation. In panels $J, K$ and $L$ multiple incistons are made in awch a way that two independent pulating oir cuita are obtained. Since the point of olimulation can only be tin one of these circutits it tia avident that it plays no essential role in the maintenance of circitating excitation. 
With respect to the mechanism of initiation of circus movement, however, MAYER still had exroneous ideas. He stated that, commonly, the waves which arise from the stimulated point are unequal, one being strong and the other weak. Vhen the "strong" contraction wave meets the "weak" one at $180^{\circ}$ from their common point of origin, he believed that the strong wave would be capable of stimulating the tigsue over wich the weak wave has just travelled. In figure 5 the diagrams are shown which MAYER used to illustrate this wrong concept.
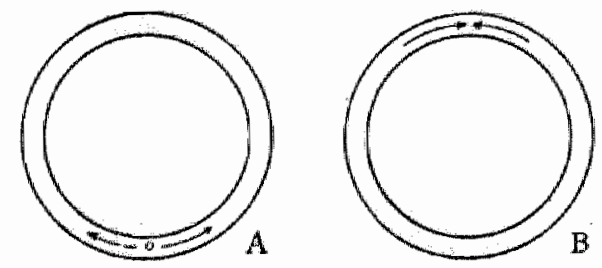

-Anunding of pulsation which occurs when two wares of equal magnitule, coming un opposile directions, meet each other.
FIGURE 5. Diagrams drow by Hayer (1908) thlustrating his erroneous ideae about the thitiation of armas novement in mings of subumberla tissue of soyphomedusa. Note that the conoept of unidimedional blook is stith missing, and that instard he thought thot a "strong" wate, when it meets a "weak" one, is apabie of stimulating the tistue oren whing the weak wane had already tratel zed.
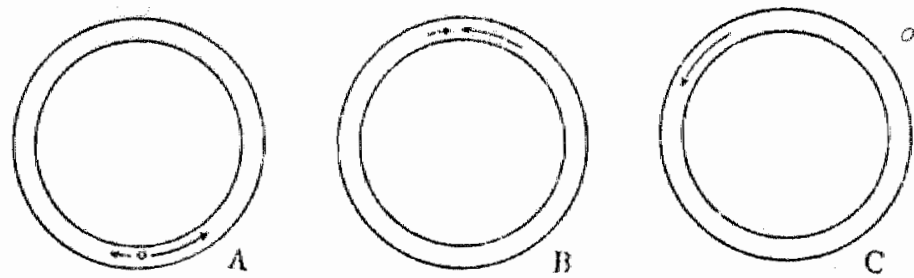

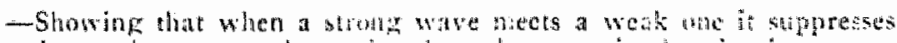
the weat wave and romains the suly wathe in the cincust.

It seems questionable whether MAYer himself was aware of the utmost importance of his observations with respect to cardiac arrhythmias. Although he repeated his dxperiments on ring-shaped strips of turtle's ventricle, in which he found the same phenomena as in the rincs of medusa, he emphasized: "It is remarkable that these isolated circuit-waves, moving constantly in one direction through a circuit, are not met with in nature. Indeed, the heart, or pulsating medusa, contains within itself the means to prevert any single pulsation-wave from coursing constantly in one direction through the tissue... Such a circuit cannot take possesion of the vertebrate heart". Fortunately, in contrast to the time of McWILLIAM, there were now two contemporary physiologists who immediately understood the fundamental significance of MAYER's observations in respect to cardiac arrhythmias.

MINES and GARREY, inspired by MAYER"s results with the rings of jelly-fish, published a number of important papers at about the same time and independently 
of each other. In these articles they made several speculations, predicting the crucial role of circus movenent in some cases of paroxysmal tachycardia and fibrillation, as observed clinically in man. MiNes (1913) first observed a type of rhythm in auricle-ventricle preparations of the heart of the electric ray and the tortoise (Fig. 6), which he designated as reciprocating rhythm. "The appearance of the heart gave the impression that the beats of the ventricle were caused by those of the auricle, while these in turn were caused by the ventricle. "This was confirmed by observation of the effect of sending in a single shock eithex to the auricle or to the ventricle. This, if timed properly, instantly arrested both chambers. It seems then that the reciprocating thythm may reasonably be regarded as due to a circulating excitation".

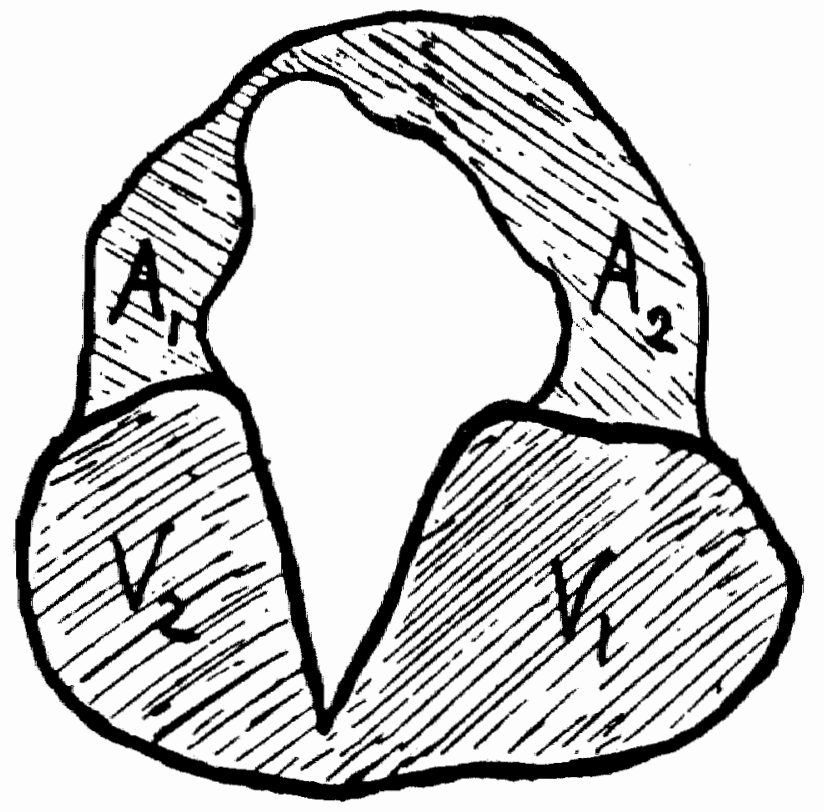

FIGURE 6. Auricte-ventricte preparation of the toptot-

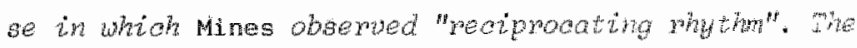

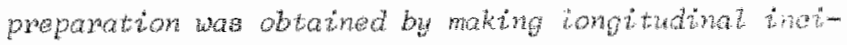

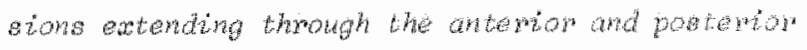

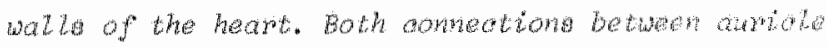

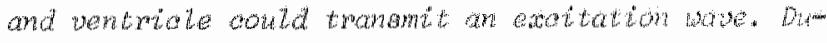
ming reatproouting whyth the folw portions of the

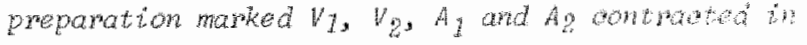
that order.

MINES as weII as GARREY emphasized the fact that for a circulating wave a unidirectional block is a necessary condition. In his explanation of the mode of onset of reciprocating rhythm, MINES considers the existence of spatial differences in refractory periods to be responsible for the occurrence of local block: "A slight difference in the rate of recovery of two divisions of the $A-V$ connection might determine that an extrasystole of the ventricle, provoked by a stimulus applied to the ventricle shortly after activity of the $A-V$ connection, should spread up to the auricle by that part of the $A-V$ connection having the quicker recovery process and not by the other part. In such a case, when the auricle became excited by this impulse, the other portion of the A-V connection would be 
ready to take up the transmission again back to the ventricle. Provided the transmission in each dixection was slow, the chamber at either end would be ready to respond (its refractory phase being short) and thus the condition once established would tend to continue, unless upset by the interpolation of a premature systole". MTNEs seemed to be very convinced that these results, obtained Erom cold-blooded hearts, also hold true for the human heart. In his 1913 paper he predicts: "I venture to suggest that a circulating excitation of this tyoe may be responsible for sone cases of paroxysmal tachycardia as observed clinicall.y". Already within one year, after KeNP (1913) described a human heart with an extensive miscular connection at the right-hand margin of the junction between the right auricle and the right wentricle, MTNEs, in his 1914 paper could not refrain from repeating this view: "I now repeat this sugrestion in the light of the new histological demonstration by stanley Kent that the muscular connection between aurloles and ventricles in the human heart is muliple. Suppose that for some reason an impulse from the auricle reached the main $A-V$ bundle but failed to reach this "right lateral" connection. It is possible then that the ventricle would excite the ventricular end of this lateral comection, not finding it reEractory as nomally it would at such a time. The wave spreading then to the auricle, might be expected to circulate around the path indicated". Later analysis of the mechanism of paroxysmal tachycardia in patients with the nolff-parkinsonWhite symarme indeed has completely confirmed this prediction (see for a review Durrer and wellens, 1974 ).

MTNEs repated his observations on ring preparations cut from auricles of ray and dogfish and from ventricles of the dog and the cat (see Fig. 7), in which he ossentially got the same results. Fig. 8 gives a reproduction of the original diagrams in which MINTs summarized his ideas on circus movement. "No fact is better established concerning the histological structure of caraiac muscle than that there exist numerous connections between the various portions or columns of cells. There exist closed CIRCuITs in the myocardium. Supposing an excitation to be started in such a closed cjxcuit and supposing that for some reason it travels in one direction but not in the other. If the rate of propagation is rapid as compared with the duration of the wave, the whole circuit will be in the excited state at the same time, and the excitation will die out (see Fig. 8a). But if, on the other hand, the wave is slower and shorter (and it is race slower and shorter by the conditions which produce fibrillation) the excited state will have passed off at the 

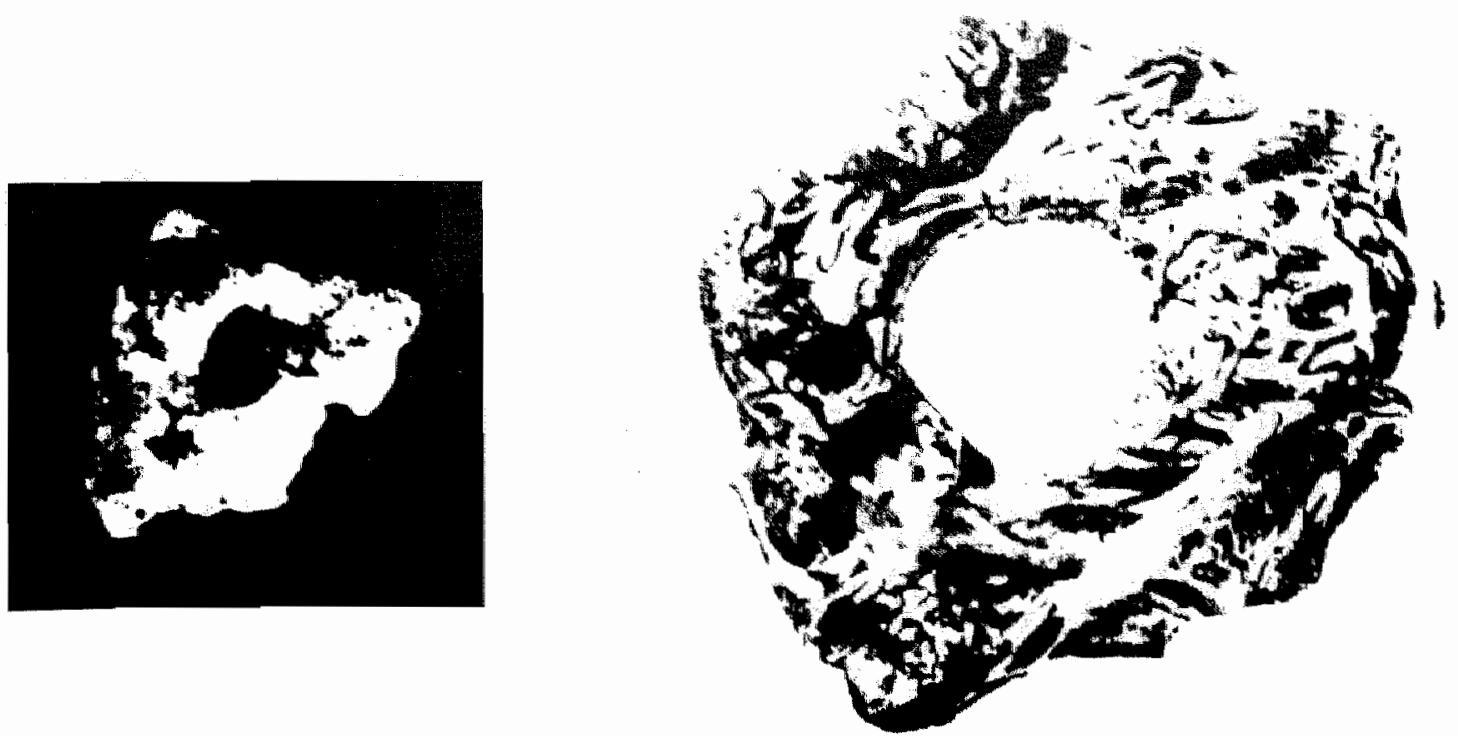

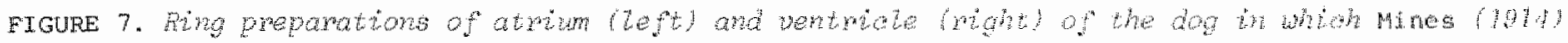
sucaeded to produce and demonetrate tme orindating excitation.
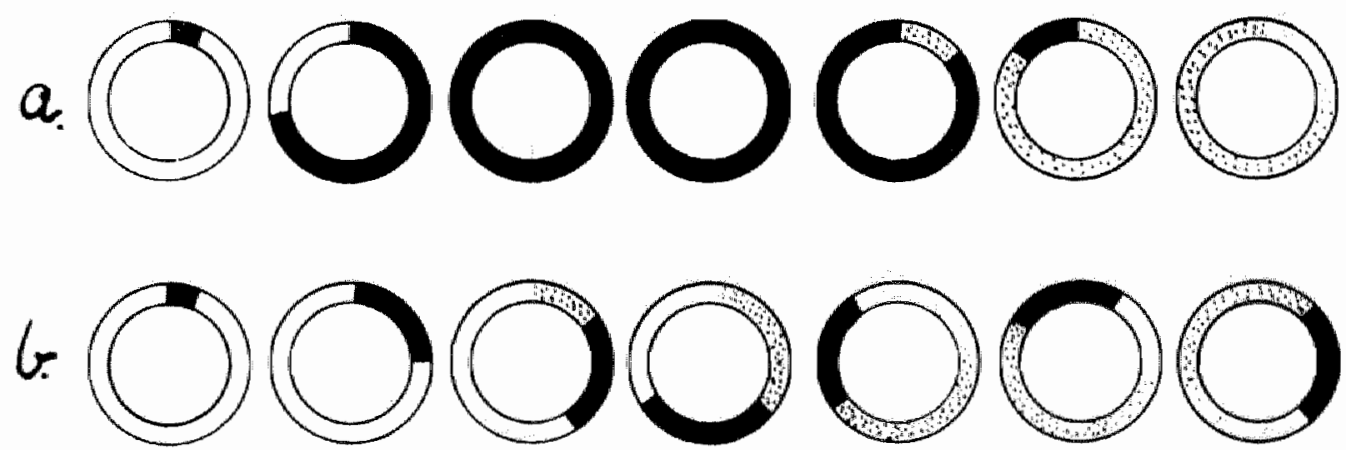

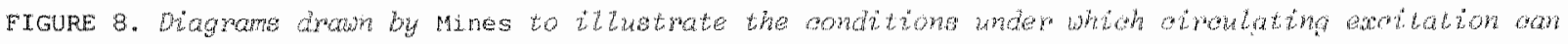

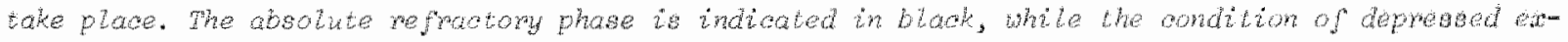

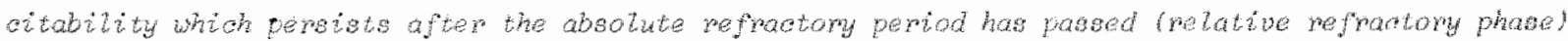
is represented by dota. Ses tert for furher axpanation.

region where the excitation started before the wave of excitation reaches this point on the circle at the completion of its revolution. Not only so, but there will have been time for the excitability of the muscle to return to about the value it had at the time of the first excitation. Under these circumstances, the wave of excitation may spread a secona time over the same tract of tissue (see Fig. 8b): once started in this way it will continue unless interfered with by some external stimulus arriving during that part of the cycle when the portion of the muscle stimulated is neither in the excited state nor in the condition of depressed excitability which outlasts it". 
Unforturately, here this briliant series of hialy original investigations was suddenly terminated. on a saturday afternoon, November 7 , 1914 , MIMS died as the result of an experiment he performed upon himself alone lnthe Medical college (see Fig. 9). One might wonder indeed if MINES had not died so prematurely, whether the history of the investigations into the mechanims of tachyarrhythmias would have been totally different.

Ir is with groat vegret that wo nunounco the doall of rolesson G. H. Mincs, who was iecently appointed to the chnir of physiology at MeCuill Lnimersity. Last wiates

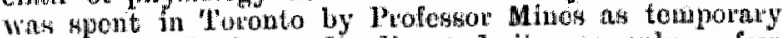
wasibatant to Profossor Hrodio, and it was only a fors

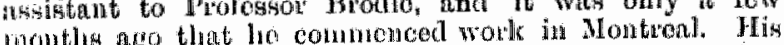
montic deatli oceurred on a Satadity afternom, Noveniber 7th. Ho was engaged on a rosentel on respiration and

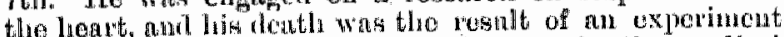
lio wos porforming apon linusalf, flone in tho wedical colkge. l'ofosson Mines, who wns born at Batli twenty-

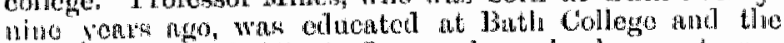

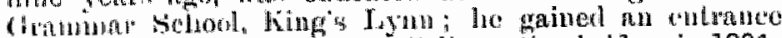

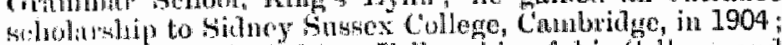
in 1909 he was chouted to a Irellowship of his College, and

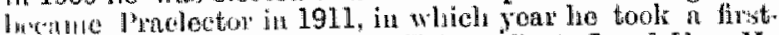
chas in the Natural Scionoe Ilupos (1'arts I and III. Ho was niklitional domonstintor of physiology in tho Cinivensity of Combridere from 1917, to 1914, and director of physiology in the fistfon laboratony from 1920 to 1913. finclowed with a possion for music, Minos at first thought of cotoring upon a musical tarcer. His liking for natural

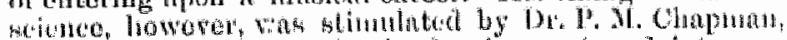

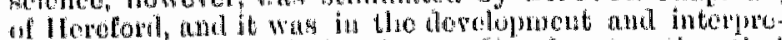
hation of exact mothods of rearding hoart netion that

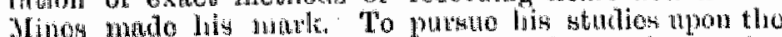

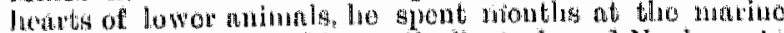

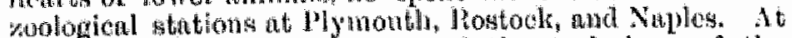
tho Marey Institute lne mastoned the teolnigno of tho "inematogreph, of which tho poognized tho value ns n roconil of indmal morenowits. Poskossed of gront potsonal

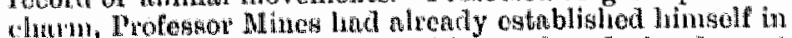
tho houtts of his thespointes at Montronl, and tho deepest wympatly is fell for his young widow and her two litto chilkton.

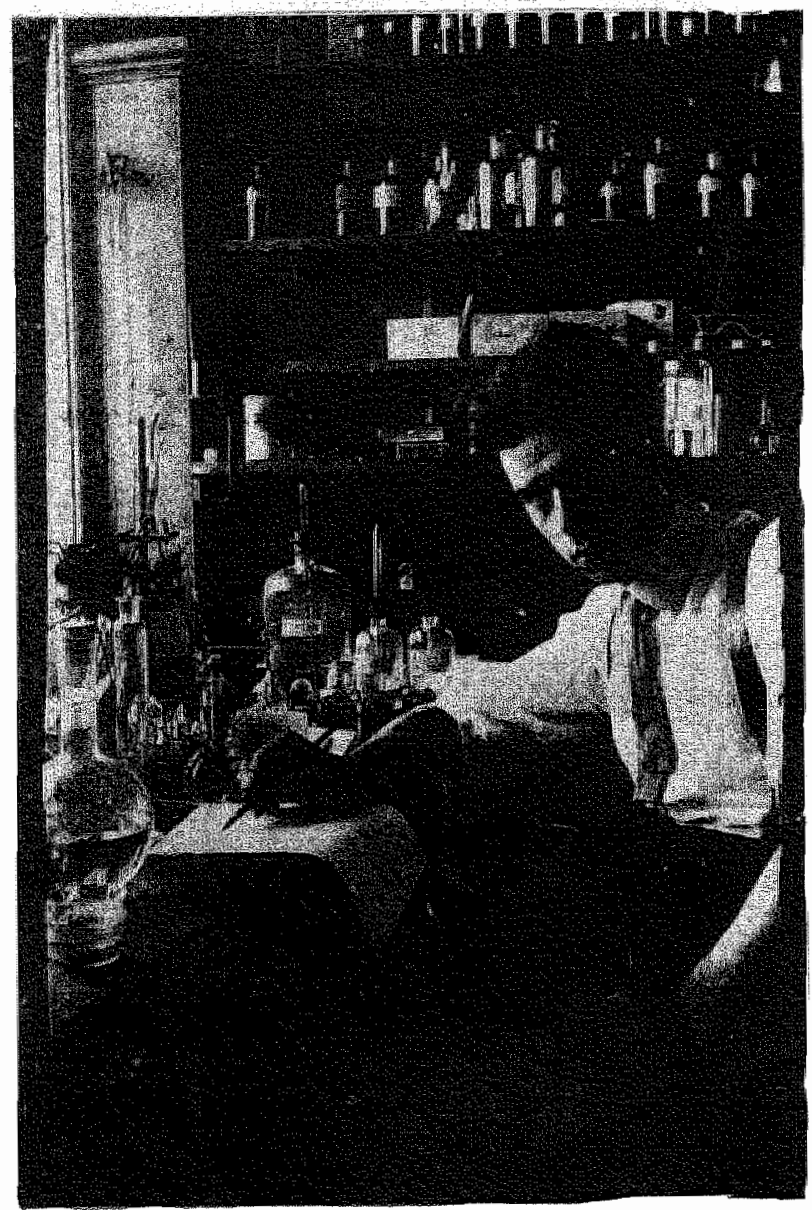

Figure 9. Photogmaph and oditudry of G.R. HWES.

GARREY (1914) completely confirmed MJNES findings in ring preparations cut from turte ventricles. Both authors also agree in their concept that fibrillation is due to multiple waves traveling in closed circuits in the syncytium. In this respect GARREY did the intexesting observatiom that xings, two centimeters wide, cut from the base of the fibrillating ventricles of large loggerhead turtles did not recover from the Eibrillary contractions; however, converting this broad 
ring into a smaller and longer one it was found that "incoordinated fibrillary contractions had resolved themselves into a number of contraction waves which followed each other successively and repeatedly axound and around the $x i n g "$. So one can conclude that in 1914 the efforts of the biologist MAYER and the physiologists MINES and GARREY resulted in the concept of circulating excitation and the suggestion that this phenomenon played an important role in various cardiac arrhythmias. For a detailed review of these early studies see GARPEY, 1924 and RYTAND, 1966.

Circus movement in the atrium

In the next decades clinicians were to test the validity of the circus movement hypothesis as an explanation for tachycardia and fibrillation in man. This was started with great energy by Sir Thomas LEWIS and co-workers in the Medical College Hospital in London. This laboratory originally adopted the theory that tachycardia and fibrillation were based on heterogenic rapid impulse formation. In 1918, although he knew the work of Mayer, Mines and Garrey, LEwIS st111 "Leaned to the view that irritable foci in the muscle underlay tachycardia and fibxillation". However, since he was deeply convinced of the necessity to use exact methods to support a given proposition, LEWIS determined to test this hypothesis. He originally thought that MINES" view of circus movement could easily be disproved when applied to clinical arrhythmias. However, the result was guite opposite! LEnIS and his co-workers needed a series of no less than nine papers to analyze the problem (Observations upon flutter and fibrillation, Parts I - IX 1918-1921). The last part (IX) of this series he concluded with: "We began, fortunately as it transpired, by attempting to follow the path taken by the excitation waves in flutter; it was not until we had seen pure and long-continued flutter, that the full significance of experiments on ring preparations was recognized. We were driven slowly to the conclusion that pure flutter consists essentially of a simple circus movement; in coming to that conclusion we were guided by the dramatic experiments which MINES and others had conducted upon rings of muscle. From the time when we felt able to conclude that pure flutter is comparable to this ring experiment, and that in flutter a wave circulates around a natural. 
opening in the muscle of the auricle, the course of the investigations became simplified".

This conclusion was based mainiy on the study of only two dogs with pure atrial flutter induced either by weak faradic stimulation of the auricle, or by xhythiji stimulation rising in rate until a critical frequency was reached. Fig. 10 and 11 show the most complete results LEvIS together with FEIL and STROUD (part II, 1918-20) were able to acquire (og $\mathrm{kO})$. During a period of pure flutter, lasting 35 minutes after rhythmic stimulation of the mid-caval region at a rate of 573 per minute, the auricles were examined by taking records from a standard lead (lead II) and from direct leads at various points on the auricular surface. The spread of the excitation wave during flutter was traced by measuring the intervals between the intrinsic deflections of the direct leads and the corresponding auricular sumit in lead II. In Fig. 10 the moments of activation of the different recording sites are given in relation to the auricular complex from Iead II.

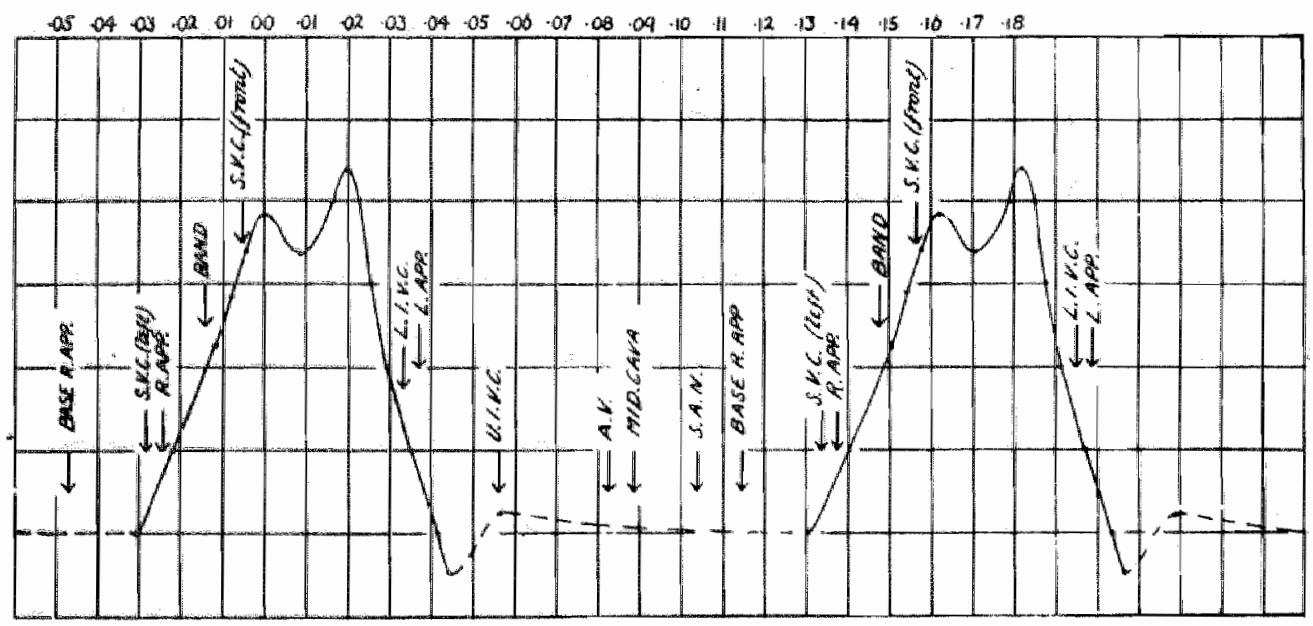

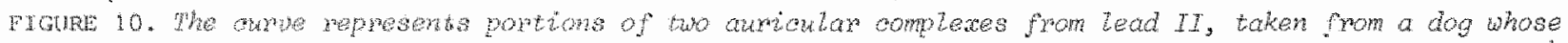

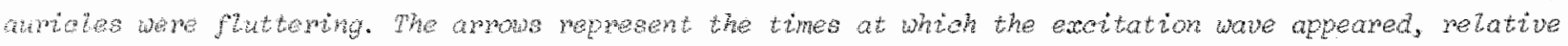

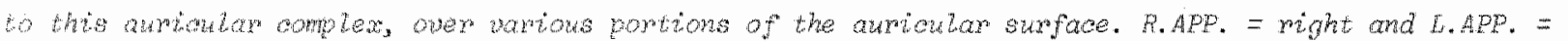

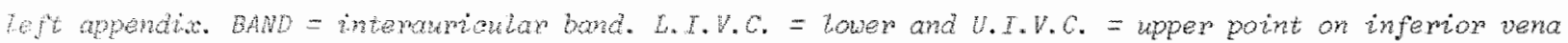

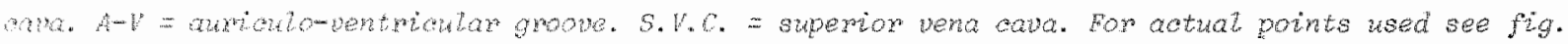

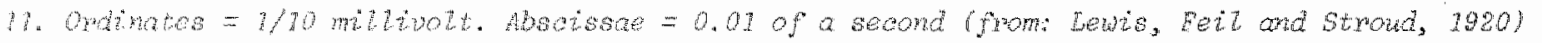




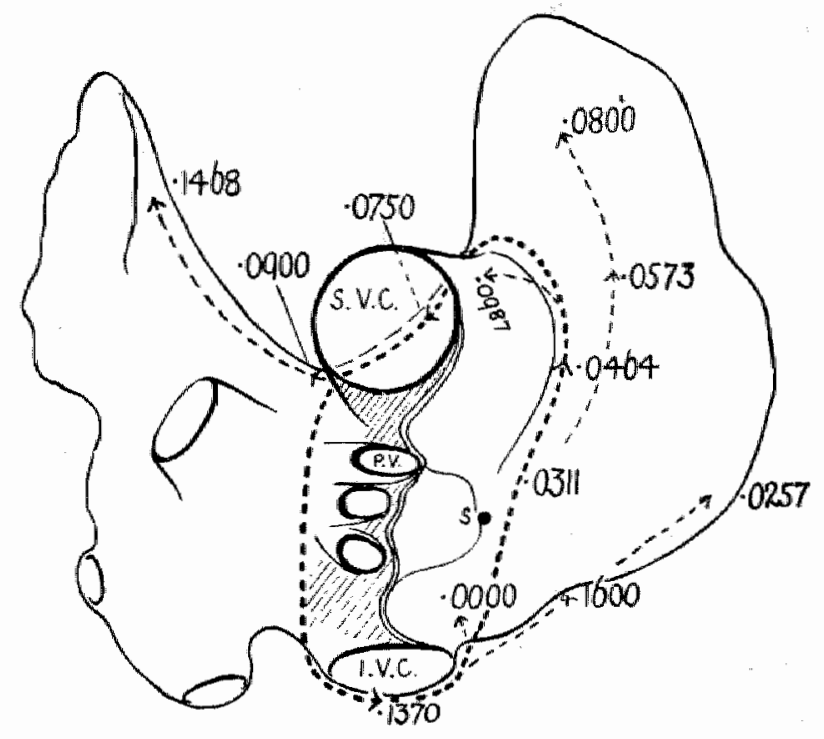

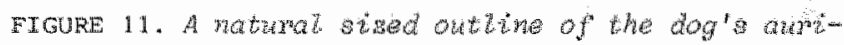
che showng the reading obtathed andw a period of futer. mhey hove been wated to a new wero. The

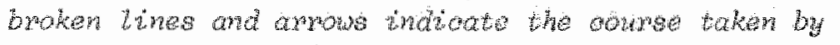

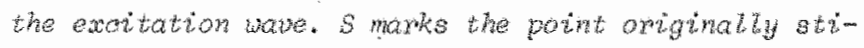
mitated to induce flutere (Lemis, fent and stroud. $1920 !$

Figure 11 shows the spread of the excitation process, as emerged from relating the moments of activation with the exact sites of recording. In this map the intrinsic deflection in the inferior caval lead has been chosen as a new zero time. Most of the pathway taken by the activation wave during the period of flutter could be identified by this method. During one cycle of the tachycardia (beat to beat interval $0.160 \mathrm{sec}$ the wave travels from the inferior cava up along the crista terminalis and to the right auricular appendage. It then turns around the orifice of the superior cava, and passes along the interatrial band to the left atrium; a little later a new wave appears behind the inferior cava and the sane sequence of activation is repeated. However, as LEWIS himself emphasized: "It remains to ascertain if this new wave is a continuation of the old one; if so, then a circus movement is proved". Unfortunately, direct measurements along the left. side of the entrances of the caval veins were not obtained. Instead, indirect evidence was used to support this hypothetical part of the pathway. First of ali the matter was tested by measuring the length of the supposed path of this circulating wave, and by calculating the times at which it would arrive at the several recording sites, assuming that during one cycle of the tachycardia (1asting $0.160 \mathrm{sec}$ ) the impulse just completed one revolution in the circuit (the length of the circuit was measured to be $137 \mathrm{~mm}$ ). Doing this, the actual and calculated times turned out to be in close agreement. The wave arrived at each measuring point at the moment it was expected to arrive, supposing the impulse cixculated as indicated in the map of Fig. 11. 
A second argunert was drawn fron experiments in whin the auricies were artificially paced from the inferior vena cava (see Fig. 12). Comparison of figures 11 and 12 makes clear that the sequence of excitation duxing pacing differed considerably from that during flutter. It is true that in both cases the wave spreads up the crista terminalis, but the main difference is that in case of artificlal pachng the impulse spreads simultaneously to the left auricle reaching the interatrial band by a shorter path and in shorter time. On the basis of these data and arguments LEWIS decided that: "There remains little doubt that we are dealing with a wave moving around the cavae, the movement being continuous and completes once during each auricular cycle.... in some instances the wave follows the same path in the reverse direction; in other it would appear to circulate, not around the cavae, but in some other ring of muscle such as that surrounding the mitral orifice; the events vary to this extent".

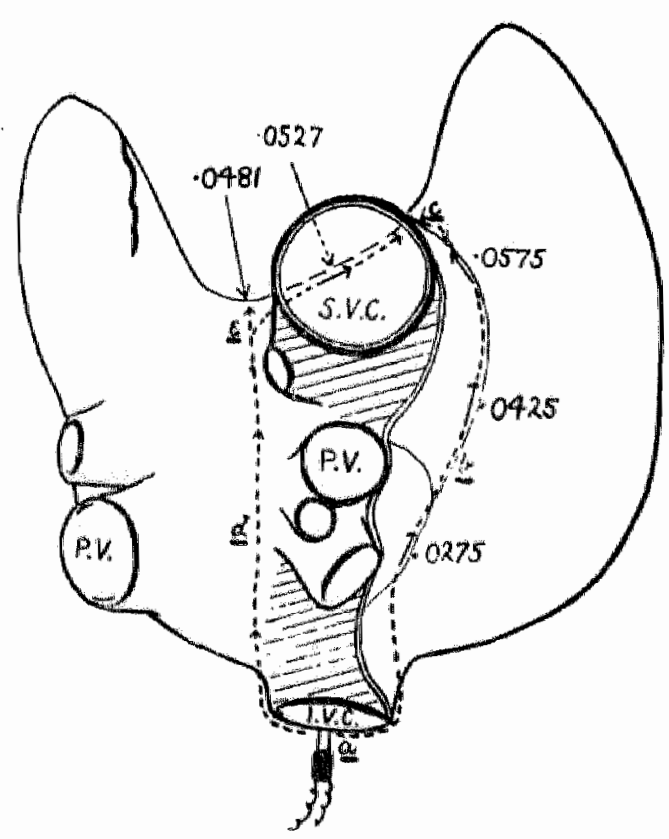

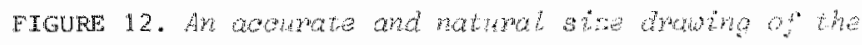

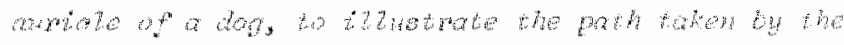

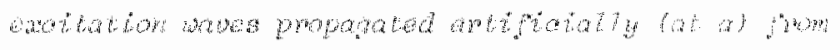

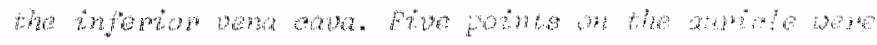

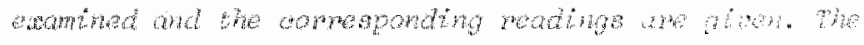

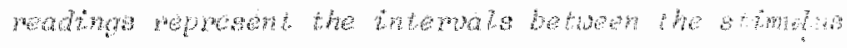

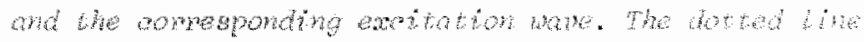

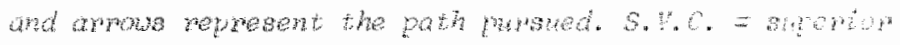

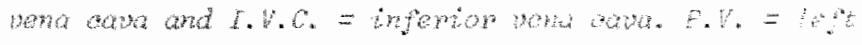

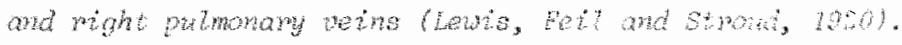

Later studies have come to the same conclusion (ROSENBLUETH and GARCIA RAMOS (1947); KIMURA et al. (1954); LANARI et al. (1956); HAYDEN et al. (1967). The studies of KIMURA et al. (1954) supplied complementary data with respect to the spread of excitation at the left side of the venae cavae, where IEUIS, FEII and STROUD were unable to take records. Fig. 13 shows the chain of electrodes they used to explore the area between the venae cavae and the pulmonary 
veins, together with the resulting more complete map of the pathway of the excitation wave during flutter. The results completely confirm the conclusions of LEWIS et al.
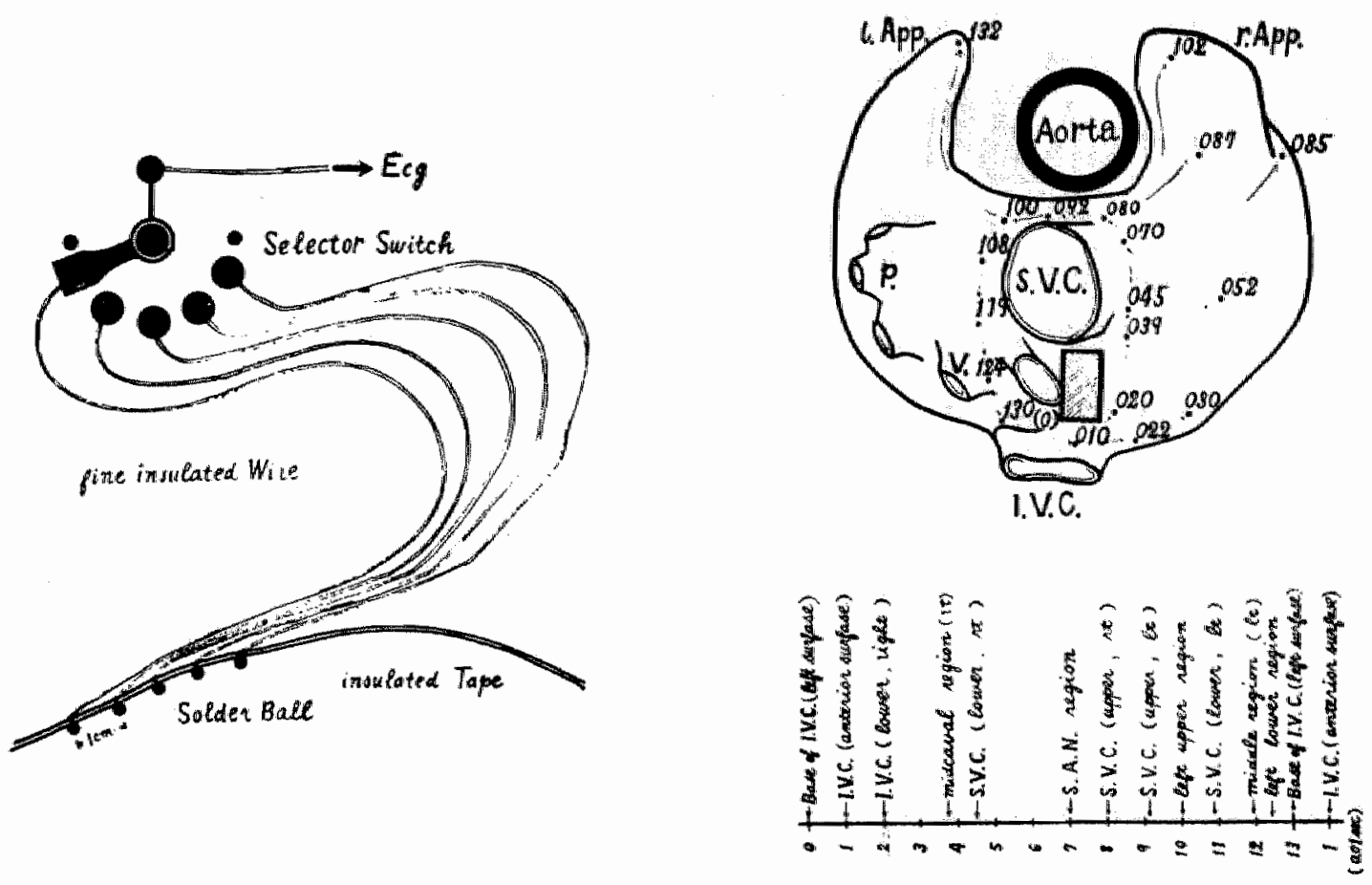

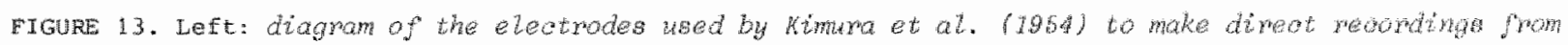
the teft anterdats surfore.

Right: Dutine of the cephatio surface of a dog's auriole, whowing the readings for the arwival of the

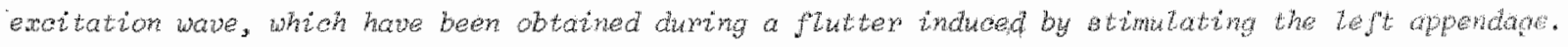
Aurioular aycle is 0.120 sec. Below the map a chart is giver, whowing the the relatton of the different mecording sites during one aycle of the flutter.

The involvement of obstacles in atrial flutter has been emphasized by ROSENBLUETH and GARCIA RAMOS (1947), and later by KIMURA et al. (1954). These authors found that crushing the conducting bridge between the two venae cavae, which converted the two orifices into a single obstacle, maxkedly facilitated the induction of flutter by rapid stimulation. Enlargement of the obstacle decreased the rate of the flutter. However, when the lesion was extended to the auriculo-ventricular groove (that is, as soon as the obstacle was not longer entirely surrounded by conducting tissue), the fluttex was suddenly terminated and could no longer be reinitiated (figures 14 and 15 ). 


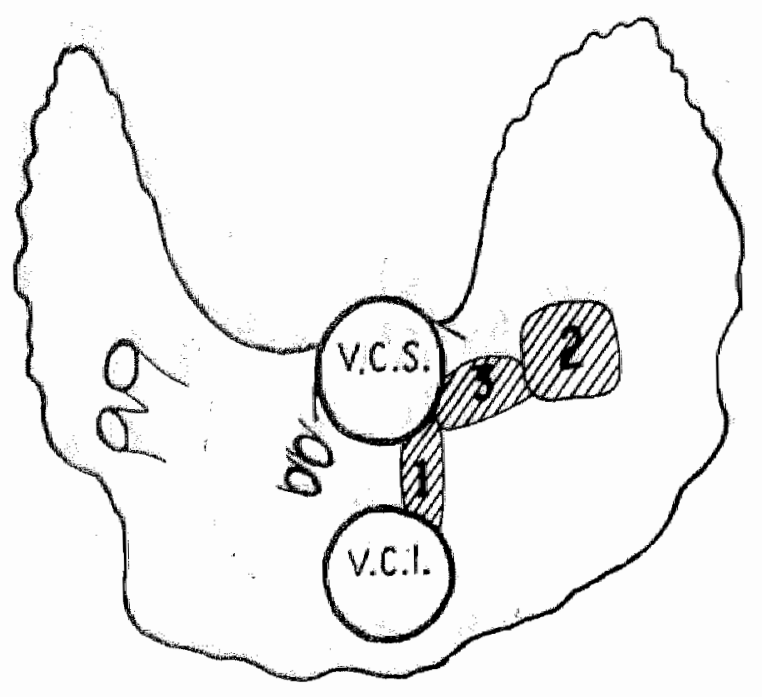

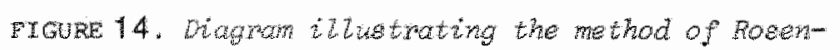
buth and Gareta Romos (1947) to fastititate the in-

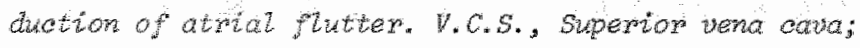
V.C.T. ingemor vena cava. When the intervenows re-

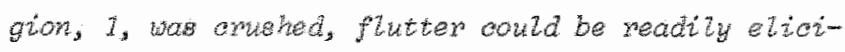
ted. An additiont lnjwy, 2, did not modify the rate of this fluter as long as the addtional abstacle was wot connected whth that represented by the two cavae. But when the tho obsactes were joined by the orut represented by the rate of the futter was signt-

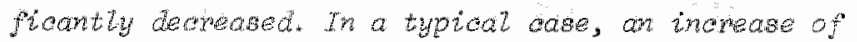
the effeotwe perinters of the obstacte from 9.0 to 12.7 centimeterg, resulted in a siowing of the rate of the putter from 7.1 to 6.3 pep second.

\begin{tabular}{|c|c|c|c|c|c|c|}
\hline \multirow{2}{*}{$\begin{array}{l}\text { Experis } \\
\text { ment } \\
\text { ino. }\end{array}$} & \multicolumn{3}{|c|}{ Before whiening of the blocked area } & \multicolumn{3}{|c|}{ After widening of the blocked area } \\
\hline & $\begin{array}{l}\text { eycle } \\
\text { length } \\
\text { sec. }\end{array}$ & $\begin{array}{l}\text { frequency } \\
\text { per min. }\end{array}$ & $\begin{array}{c}\text { length of path- } \\
\text { way (estimated) } \\
\text { cm. }\end{array}$ & $\begin{array}{c}\text { length of path- } \\
\text { way (estimated) } \\
\text { cm. }\end{array}$ & $\begin{array}{l}\text { calculated } \\
\text { frequency } \\
\text { per min. }\end{array}$ & $\begin{array}{l}\text { obserwed } \\
\text { frequency } \\
\text { per min }\end{array}$ \\
\hline 1 & 0.130 & 461 & 12.0 & 14.9 & 370 & $41+$ \\
\hline 2 & 0.120 & 500 & 12,0 & 13.0 & 461 & 480 \\
\hline 3 & 0.125 & 480 & 140 & 15.5 & 401 & 428 \\
\hline+ & 0.130 & 461 & 13.0 & 15,0 & 393 & 414 \\
\hline 5 & 0.115 & 522 & 12.0 & 14.0 & 447 & 454 \\
\hline 6 & 0.122 & 492 & 14.0 & 16.0 & 430 & 423 \\
\hline 7 & 0.110 & 545 & 12.0 & 15.0 & 467 & 545 \\
\hline
\end{tabular}

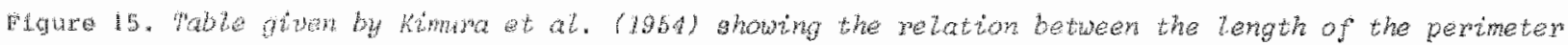

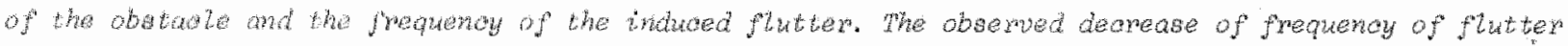

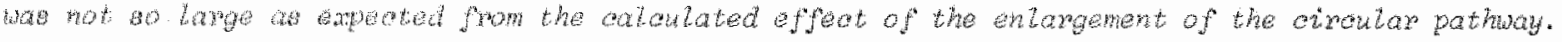

over the years little attention has been paid to circus movement without the involvement of an anatomically preformed pathway. Nevertheless this has obvious consequences for the properties of a circus movement tachycardia. LEWIS was one of the few who realized that the behaviour of circulating waves in the intact heart probably would be much more complicated than in the artificial narrow rings of muscle. In his famous monograph "The mechanism and graphic registration of the heart beat" (1925) he spends a whole chapter on this subject (chapter XXVII). There he gives some theoretical considerations about the properties of circulating excitation in a simple narrow ring compared with circus movement in a sheet of muscle. Because these eaxly ideas seem to be ignored by many following investigators and because LEWIS" theory of circus movement comes so close to the "leading circle" model as introduced in this thesis (see chapter 5), I think it 
is useful to quote the relevant passage in full. First the properties of circus movement in a narrow ring are described:

"Broadly speaking, such circulating waves are governed by three factors, which in themselves are often closely interdependent.

a. the length of the muscle path;

b. the rate at which the wave travels;

c. the duration of the refractory state at a given point. If a wave is propagated along one limb of a muscular ring and returns to the point stimulated, it can find this original point responsive and traverse it in one circumstance only. The refractory periad at the point in question must last a shorter time than it takes for the wave to travel the full circle. The time taken for the wave to travel will depend upon the length of path and upon the rate of propagation. Thus, if the ring measures 100 millimetres in circumference and the wave travels at 500 milimetres per second, it will complete the circuit in 0.2 of a second. If the refractory period lasts 0.15 of a second, it will end 0.05 of a second before the wave returns. If the ring measures only 50 milimetres, or the rate of propagation is 1,000 millimetres a second, it will complete the circuit in 0.10 of a second; it will return to its point of origin and, finding the muscle still refractory, will be unable to proceed. The conditions favourable to circus movement establishing itself are, therefore, a large ring, a slow rate of conduction, and a short refractory period. These three factors are largely interdependent. The rate at which the ring beats as a whole is governed by the circulation time. If the circulation time is 0.2 of a second, then 300 circuits or beats of the ring will be completed in a minute. The smallex the ring and the quicker the conduction in it, the more rapid is the beating. Upon the rate of beating will cepend the length of the refractory period, it will be shorter as the beats are faster; upon the length and end-condition of the refractory periad will in large measure depend the rate of conduction. Further consideration of these interrelations is much simplified if we fix our attention on the gap which exists between the crest of the advancing wave and its wake of retreat. If the circult is completed in 0.2 of a second and the refractory period lasts 0.15 of a second, the gap is equivalent in time to 0.05 of a second or to a segment forming $1 / 4$ of the whole ring. The factors influencing this gap are easily to realize. When the path is shorter or conduction is quicker, a greater proportion of the ring will be 
rendered refractory in a given period of time. When the refractory period is long, the crest of the wave has a longer time to travel before its tail begins to retreat. Each of these changes reduces the extent of the gap therefore".

\begin{tabular}{ll}
\hline $\begin{array}{l}\text { Decreasing and tending } \\
\text { to abotish the gap }\end{array}$ & $\begin{array}{l}\text { Increasing the } \\
\text { gap }\end{array}$ \\
\hline & Longer path \\
Shorter path & Slower conduction \\
Luicker conduction & Shorter refractory period \\
\hline
\end{tabular}

Then he applies these properties to the situation in which the wave is not circulating in a narrow ring but in a large sheet of muscle:

"he have been dealing, in speaking of circus movement, with a simple and narrow ring of muscle of fixed circumference; such does not exist in the auricle. It is true that there are natural rings of tissue around the mouths of the great vessels and around the auriculo-ventricular orifices, but each of these is more correctly viewed as a circular hole in a flat sheet of muscle. Thus, there is a ring adjoining the orifice; there are also outer rings, greatex in circumference, at distances more removed from the orifice. These auter rings provide optional paths fox the wave and introduce a new possibility, namely, change in the length of cirait travelled. Suppose that the responsive gap in a ring of tissue immediately surrounding a natural auricular orifice is represented by Fig. $310 A$ (see Fig. 16 of this chapter), and supposing that for some reason the refractory period becomes longer, the gap will close (Fig. 310B).
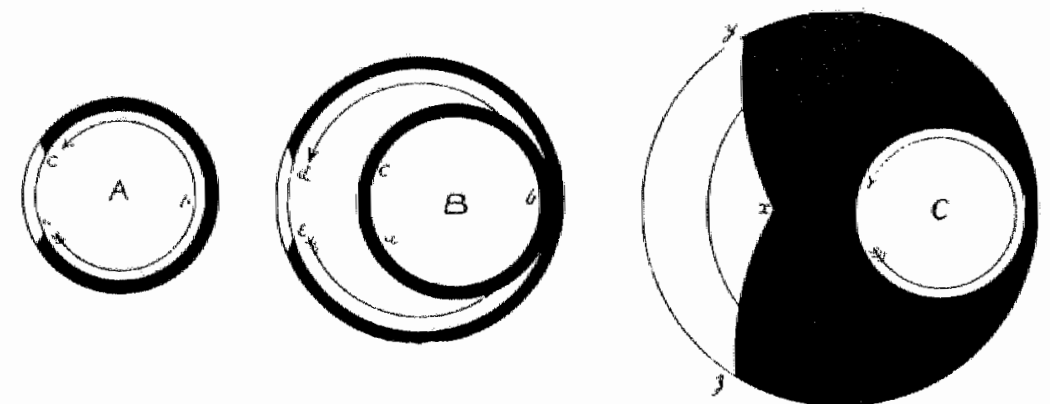

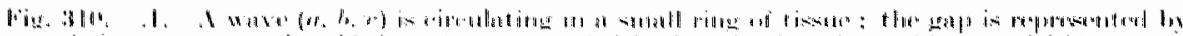

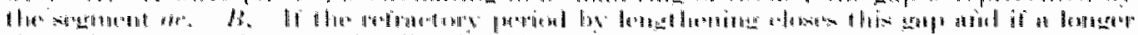

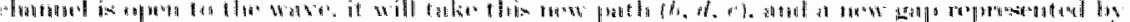

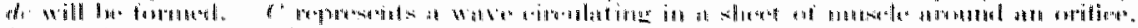

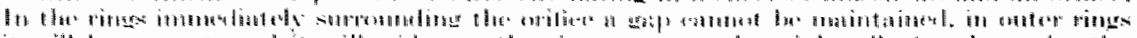

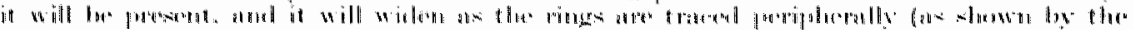

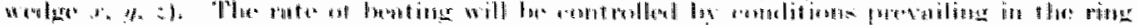

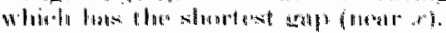

FIGURE 16. Reprodueed from LEWIS, 1925. 
This closure will not end the circus movement, providing there are longer paths open to the wave; it can still circulate and will circulate, upon such a new path if the conditions are there suitable (Fig. 310B). When a wave circulates around an orifice in a sheet of muscle the size of the gap will be greater as we pass from inner to outer circles of muscle, as is shown in Fig. $310 \mathrm{c}$. At any given instant the gap is represented by a wedge of tissue, its point (x) lying towards the center and its base $(y z)$ lying peripherally. The conditions existing in the circle of muscle in which the gap is shortest, the circle which includes the point of this wedge in the diagram, are those which determine the rate of beating of the muscle sheet as a whole. That is to say, the rate of beating is not controlled by the length of path, providing sufficient optional paths are available, for the length of path is determined by the remaining factors. It is probable, too, that the rate of conduction in these circumstances would not influence the rate of beating, since a change in conduction would at once be balanced by an appropriate change in the length of path followed. It is impossible to visualize the precise paths followed by, and available to, a circulating wave in the auricle, but it would seem from the considerations here set forth that when a circus movement is established and wher shorter or zonger paths can become anaizable, the length of the refractory pexiod is in sole control of the rate of beating".

In a footnote to this paragraph, LEwis gave as his view that a central aperture, although theoretically not really essential, yet will play an important role in practice, since: "it is difficult to see how a simple circus movement could be started in such a sheet, or how it could continue regularly without interruption" or change". However, latex studies have demonstrated that, according to theory, also in practice circus movement is possible without the involvement of an anatomic obstacle (WEST and COX (1960); WEST and LANDA (1962); ALLESSTE, BONKE and SCHOPMAN $(1973,1976,1977)$. WEST and LANDA have demonstrated that a tissue mass of only $32 \mathrm{mg}$ of atrial muscle is already enough to produce tachyarrhythias. This is in good agreement with our awn observations which demonstrated sustalned cixculating excitation in a cixcuit with a radius of orly 5 to $6 \mathrm{~mm}$.

In these studies we also compared the properties of the two types of circus movement as recognized by LEWIS. In figure $B$ of chapter 5 of this thesis (page 112), the two models are placed together and their respective properties are sum- 
marized. If one compares the "leading circle" model, which resulted from our direct measurements, with the ideas of LeWIS, which were based mainly on interpretation of indirect data, one gets impressed by the high degree of predictive value of this piece of "arm-chair" physiology.

So, from animal experiments, it became evident that in flutter-like conditions, two distinct types of atrial activation may be in operation: one in which excitation of the two atria takes place in sequence, the direction of advance of the excltation front being strictly opposite in the right and left atrial leads, and anothex in which the atrial activation corresponds to a radial spread of the impulse from a circumscribed area. Similar observations have been made in patients with atrial flutter (PUECH, 1974). To explain the latter type of activity there remain two different hypotheses: that of abnormal rapid impulse formation and that of micro-reentry. With the current tools available in caraiology, there is little hope for dipect discrimination between these two different mechanisms in man. A small localized reentry process will very much mimic a focus of rapid impulse formation since in both cases excitation waves will spread out radially, in rapid succession, to the rest of the myocardium. Our only hope therefore lies in an indreot identification of either mechanism. To achieve that goal it is necessary to know more about the behaviour of both mechanisms under various circumstances. Especially the study of changes in rate of an abnormal ectopic pacemaker and a micro-reentrant circuit in response to programmed electrical stimulation and the administration of drugs which specifically alter certain electrophysiologlo properties of the heart seems promising (ALLEsSIE et al., 1977 a, b). The relevance of the use of drugs to determine the mechanism of tachycardia in the human heart deserves to be tested. Then itmight once be possible to design a number of tests which enable us to distinguish abnormal enhanced impulse formation from micxo-reentry in patients. 


\section{Circus movement in the ventricles}

In contrast to the much greater clinical significance of ventricular arrhythmias compared with disturbances of supraventricular origin, relatively few studies have been successful in providing direct evidence that arrhythmias of the ventricles are due to circulating excitation. This is undoubtedy caused by the greater complexity of anatomy and electrophysiology of the ventricles. These and other factors raise serious technical difficulties and impose great limitations on endeavours to analyze processes underlying ventricular arxhythmias. Like in atrial muscle, also in ventricular myocardium circus movement of the impulse is possible. The founders of the concept of circulatind excitation (MAYER, MINES and GARREY) all demonstrated circulating contractions in rings cut from the walls of the ventricles. However, the suggestion that ventricular tachycardia and fibrillation in the intact heart is also based on circus movement, is derived mainly from extrapolation of direct observations on tachycardia and $\mathbf{E}-$ brillation of the atria. The analogy between the various arrhythmias in both chambers indeed is remarkable. On this ground most scientists have agreed that the basic mechanisms of arrhythmias in atria and ventricles are similar in nature. But, as LEWIS wrote: "Though there may be little reason any longer to doubt that circus movement occurs in the ventricle, evidence on lines similar bo that obtained for the auricle is desired to complete the proof". Beneath I will review some of the studies which have contributed to obtain such proof.

The first studies which provided direct evidence of unidirectional block and circus movement in ventricular muscle were carried out by SCHMITT and ERLANGER in 1929. These investigators used strips of ventricular muscle of the turtle. put in a tissue bath divided in several compartments. In certain segments of the muscle strip conduction was depressed by pressure and local application of excess $\mathrm{kCl}$. In these preparations they frequently observed partial or complete block in one direction and one to one conduction in the othex direction. Also multiple responses from a single stimulus were recorded (see Fig. 17, top panel). In this experiment the strip was passed through five chambers and four partitioning rubber curtains. Segment 1 was stimulated as indicated by the arrows. The applitation of four stimuli with a relative long coupling interval resulted in the conduction of just four impulses through the strip. But, ... "a stimulus thrown into 
segment 1 so as to produce an extra contraction immediately after the fourth contraction, called forth a long series of regular contractions arising spontaneously in segment 1 and passing thence through the length of the strip". In the lower panel of Fig. 17 the diagram which SCMMITT and ERLANGER gave to explatn this phenomenon is reproduced. The strip of ventricular muscle is represented to consist of two strata of fibers ( $A$ and $B$ ), passing through a rubber membrane $M$. Under the membrane the fibers have been subjected both to pressure injury and to KCI poisoning (segment $x y$ ). BY chance, stratum $A$ has been more seriously affected than stratum B. As a result, in A the impulse can conduct only through segmert $x y$ in the direction $y \rightarrow x$, but not in the direction $x \rightarrow y$. An impulse originating in 1 and traveling towards 5 thus is blocked in segment $x y$ of section $A$. In section $B$, however, the impulse succeeds in traversing region $x y$, although at a very slow rate. Upon leaving the region of depression at $y$, the impulse not only goes forwara again both in $A$ and $B$, but it also turns back in $A$ and, passing through segrnent $y x$, it causes a reentrant beat in segment 1 . A whole series of such reentrant beats can accur if the impulse returning throumh xy from 5, not only spreads into segment 1, but again excites the area of $B$ under $M$. Thus a circus would be started in a comparatively small area of the ventricle, giving rise to a period of tachycardia.
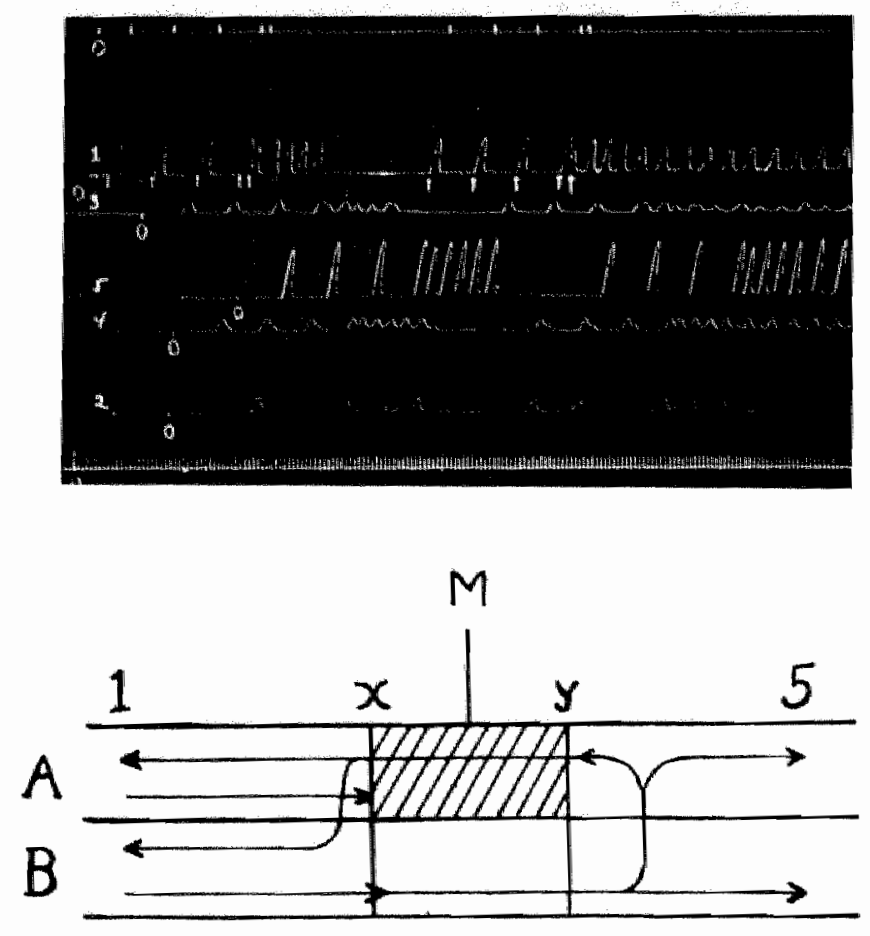

FIGURE 17. Top: Miltiple responses from a single sidmulus. The strip of ventricular musete was contoined in five chambers, the peconds beting numbred acoordingly. Segment i was stimulated as sindioated by the arabus. A series of beats follows an extrosystole after the foum contraction. Two instances of this ane shown.

Bottom: Lragram giving a hypothetical explanation of the arotythmias (from. Sahmit and Extanger, 1929). 
SCHMITT and ERLANGER further speculated that the special arrangenent of the ventricular conduction system in the mammalian heart may serve to favour reentry. This is illustrated in Fig. 18, which is also taken from their 1929 paper. It shows a twig of the $A-V$ bundle (D) dividing into two terminal branches which anastomose with ventricular muscle at $B$ and $C$. "under normal conditions, the impulse from $D$ reaches $B$ and $C$ at approximately the same time, throwing the ventricular musculature at these points into contraction at almost the same instant. But if one of the two terminal branches happened to be the site of a local lesion, or of some other state that depressed conduction in it, the conditions might very well develop which experimentally lead to a reentrant response. Then an impulse coming from $D$ would be blocked at $A$ and would die out, but by way of the other. terminal branch it would reach and stimulate the ventricular musculature at $\mathrm{C}$. The excitation from the ventricular fibers would then reenter the Purkjnje system at $B$ and traverse the region of injury, but at so slow rate that by the time it arrived at $\mathbb{A}$, the uninjured fibers there would have recovered from refractoriness and would again be excited. This excitation would immediately spread through the conducting system and reexcite the entire ventricular musculature".

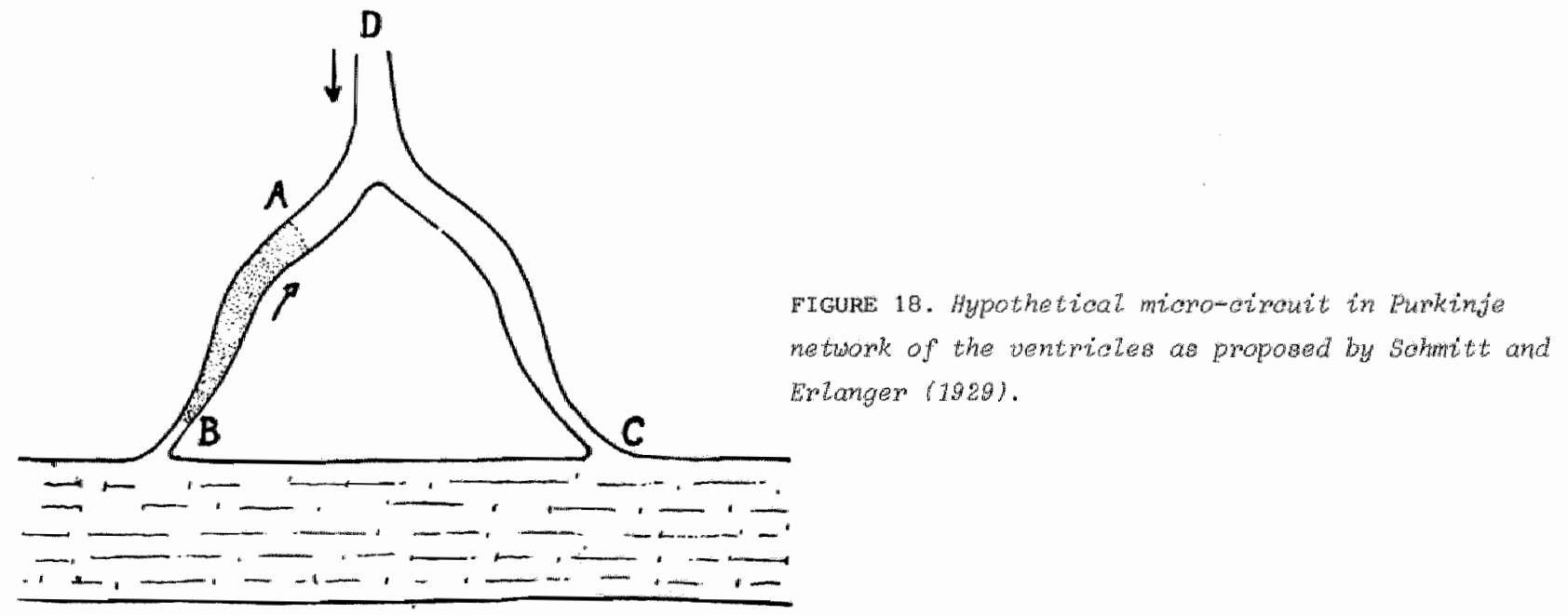

As with the atria, the discussion about reentry in the ventricles has been "focussed" on the question whether the circuit should of necessity be large or whether miniature or even micro-reentrant circuits were possible. The possibility of an intraventricular echo based on antegrade conduction along one bundle branch and consecutive retrograde activation of the other bundle followed by reentry of the bundle of His and the atria, was demonstrated by MOE, MENDEZ, 
and $B A N$ (1965). The involvement of such a large reentrant loop in which the bunde branches form an important 1ink, in some ventricular tachycardias was suggested by WELIENS et al. (1972). Subsequent observations by this author, however, revealed that this possible mechanism of ventricular tachycardia is relatively rare in man (WELLENS et al., 1974, 1975).

other studies have shown that under certain circumstances conditions may be favourable for the assessment of small reentrant pathways. The minimal dimenstons of a circuit for sustained circus movement are determined by (1) the condwction velocity of the impulse and (2) the refractory period of the fibers within the circuit. Conditions which depxess conduction velocity or/and abbreviate refractory period enable the initiation of circus movement tachycardia within a small area of ventriculax myocardium or within small loops of the specialized conduction system. Although action potentials and refractory periods of ventricular fibers nomally are of relatively long duration, MENDEz et al. (1969) and SASYNIUK and MENDEZ (1971) demonstrated that the occurrence of localized block at the Purkinje-muscle junctions was associated with marked abbreviation of action potential duration in the terminal Purkinje fibers just proximal to the site of block (see Fig. 19).
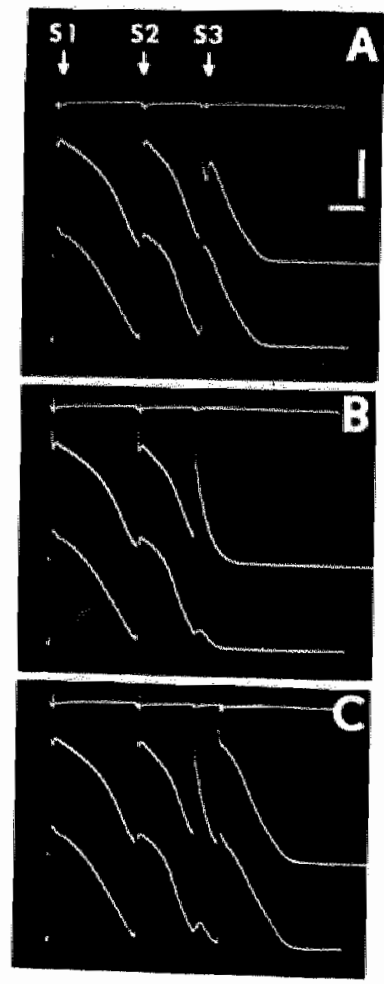

FIGURE 19. Condiotion blook at the Purkinge-masele jhotion. upper trace: eleatrogram taken from base of papilzam macla. Miade and

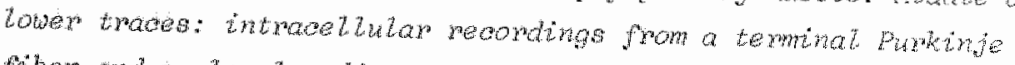

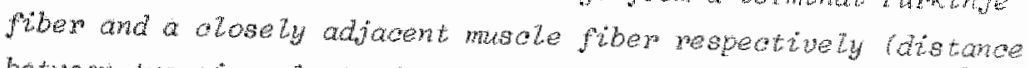

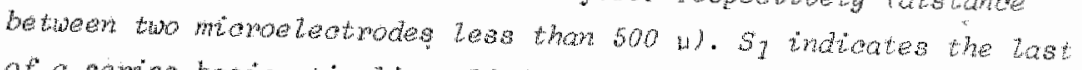
of a sumes basto stimut applied to the false tendon. Sy and $s_{3}$ :

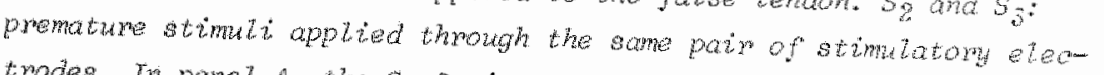

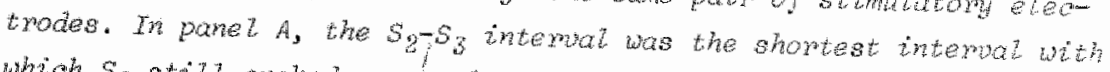

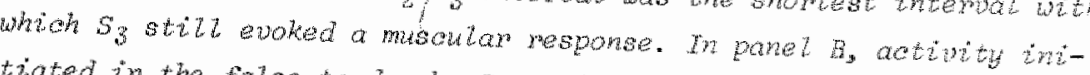

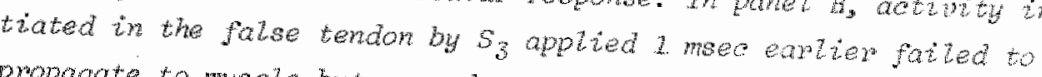
propagate to macle but caused an exwemely bries pesponse in the terminal purkinge fiber. In panet $C$ the Sg-S intremat was the same 28 in pane? $B$ and the impulse was agatin blocked at the jugction. However, now the impulse reached musce at other sibes and retwmed to aotivate the muscle fiben wh to mexate the nearly temand

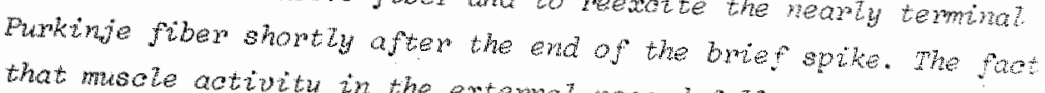
that musce activity the external record fot tows the reenthint beat indicates that the umpuse cmerged in mecte at a site closen to the intracetratar electrode than to the extermal ateotmole.

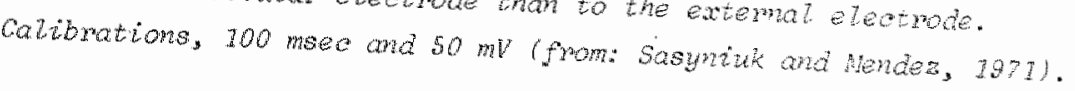


They showed that these brief action potentials may be of great importance in the development of intraventricular reentry, especially for the creation of oitcuits of no more than a few milimeters in circumference. Fig. 20 gives some examples of multiple reentries in the region of the purkinje-muscle junction.
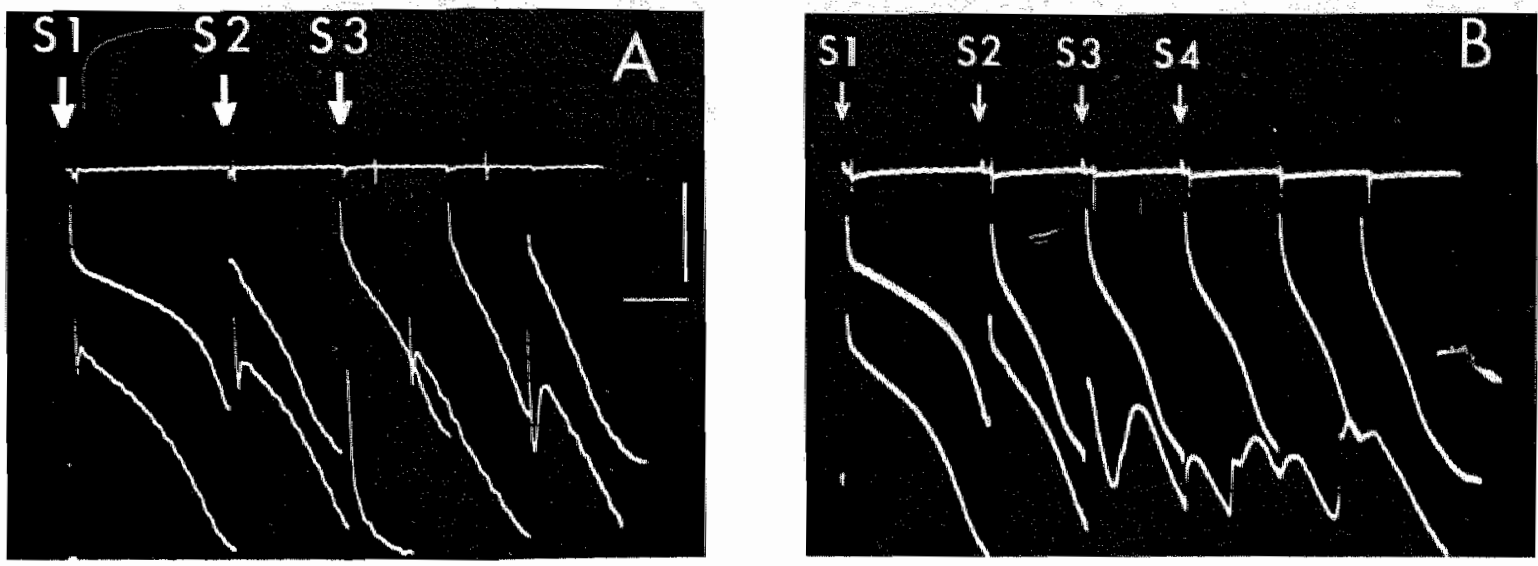

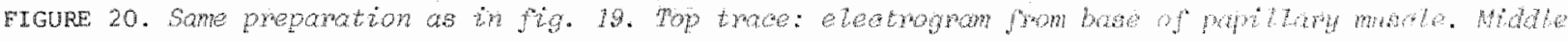

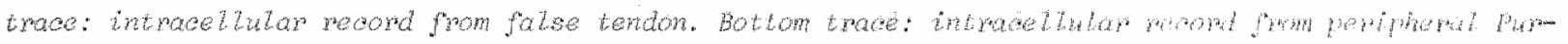

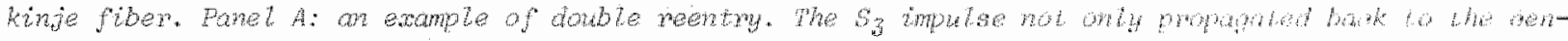

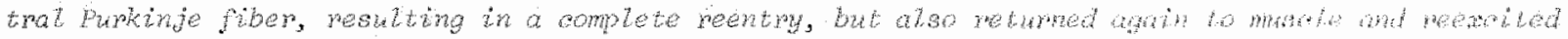

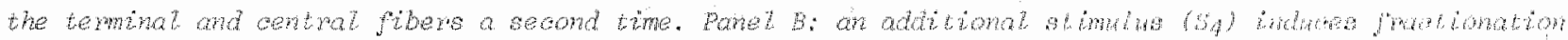

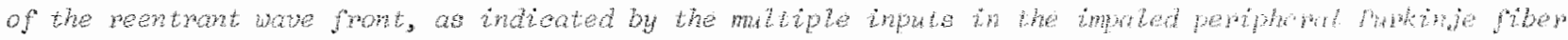

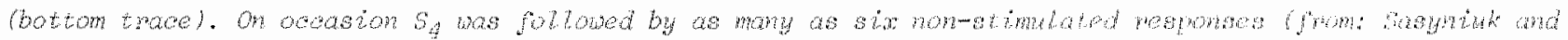
Mande: 7971 .

The role of depressed conduction in the occurrever of remtrant axcitedon after being emphasized by SCHMITr and FRIANGR (1929), has been thoroughly reinow vestigated by CRANEFIFLD et al. (1971), CRANEFIELD and HOFEMAN (1971), and WIT et al. (1972 a,b). The former authors studied the propextes af s low conductor in bundies of excised canine purkinje fibers depressed by partial ancasing the false tendon in agar containing $47 \mathrm{~mm} \mathrm{~K}^{+}$(Fig. $21 \mathrm{~A}$ ). Conducton velocjuy within the depressed segment Eell as low as $5 \mathrm{~cm} / \mathrm{sec}$. All kjnds of abnormalities of impulse transmission including oneway block were observed, proving that conduction delays, long enough to permit reentry, can occur in short segments of purkinje fibers subjected to high $K^{+}$. They further demonstrated that the slow responses in the depressed area showed the phenomena of "summation" and "inhibition" (see Fig. 21 B, C). As a result of sumation an impulse can be propagated energing out of a branch at the point where sumation occurs and thus reexcite the entire heart. So far, however, it is not known whethex this mechanism is operative in many of the ventricular reentrant arrhythias. 

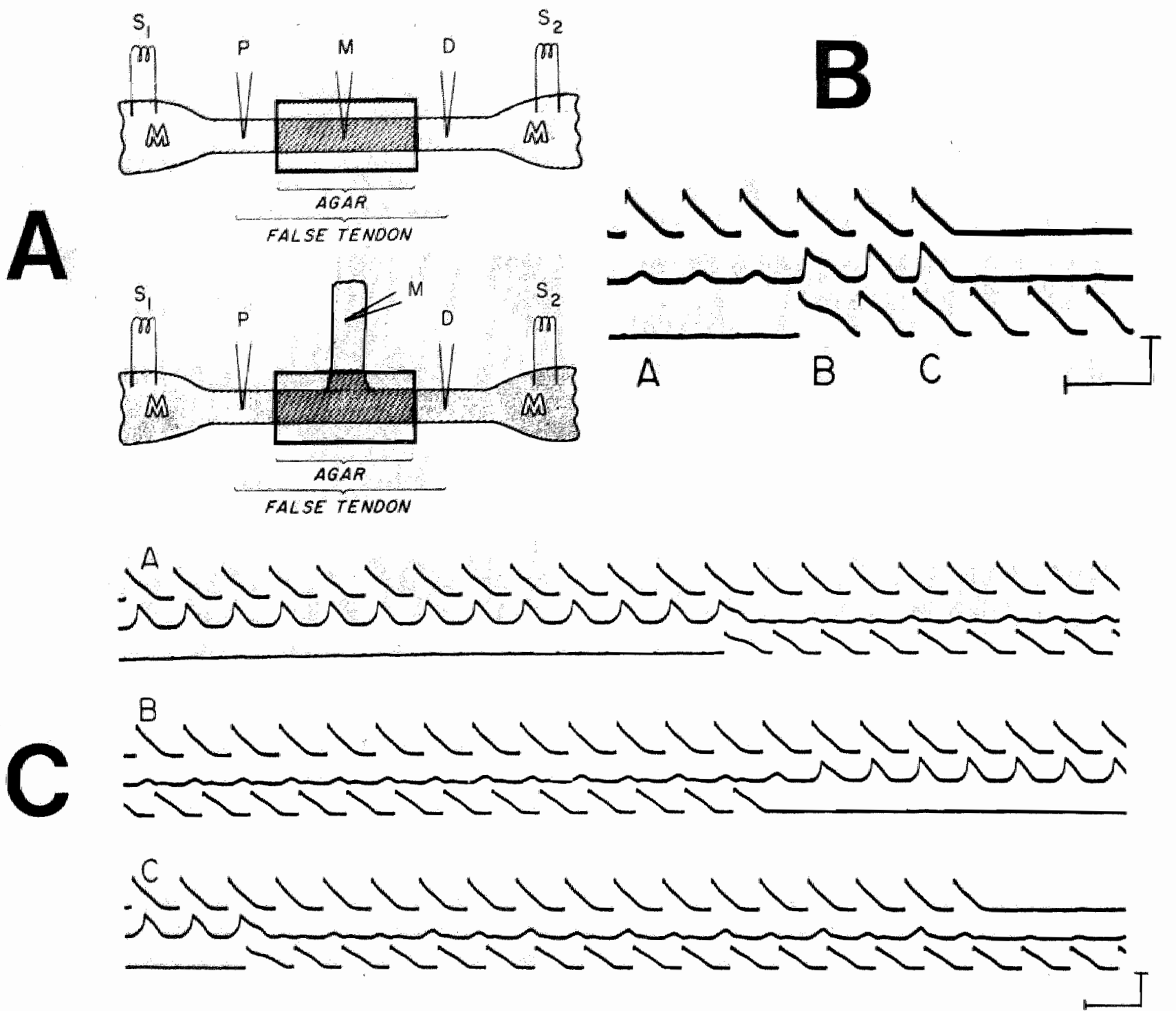

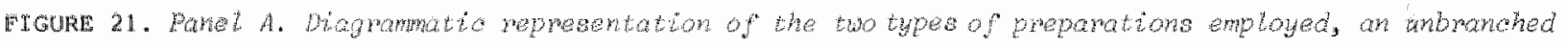

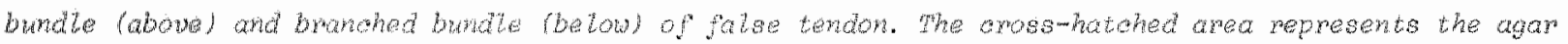

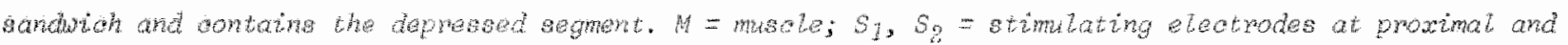

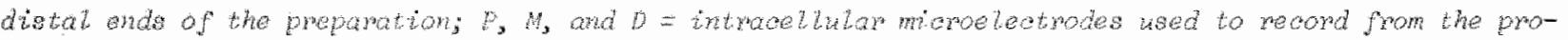

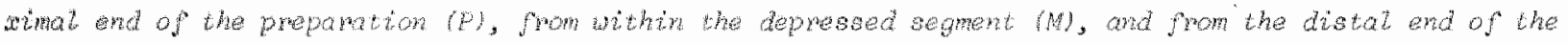

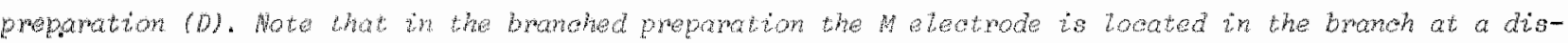

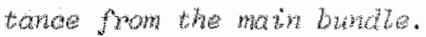

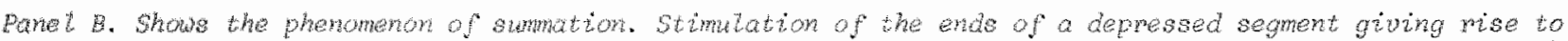

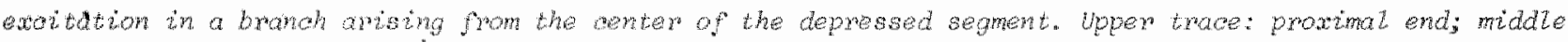

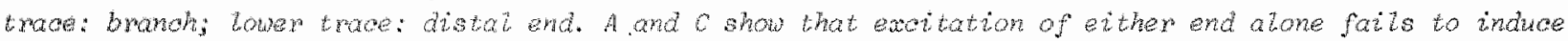
an acton potertiat in the browh. In B excitation of both enda teads to the appearance of an action po-

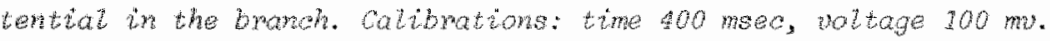

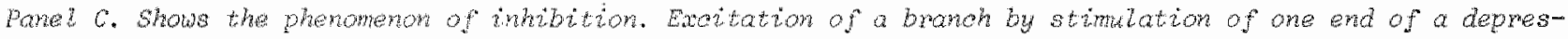

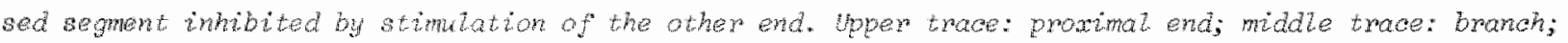
lower trace: distal ard. In A axt tation of the proximat end alone gives rae to regular exatation of the

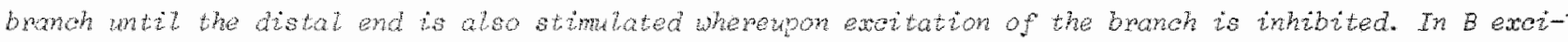
tation of both ends gives pras to wo exthtion in the branoh; then stimtation of the atotat and is stop-

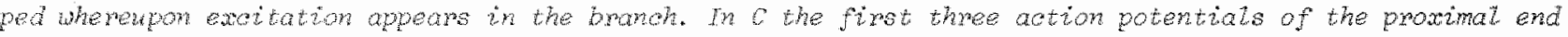

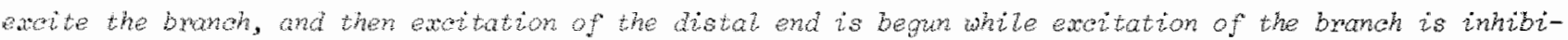

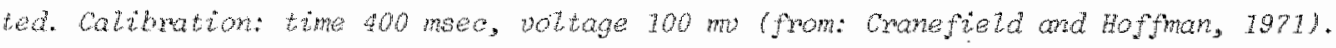


WIT et al. (1972 a) demonstrated single reentrant beats in isolated bundles of Purkinje fibers in which conduction was depressed by perfusion with a modified Tyrode solution containing high $\mathrm{k}^{+}$and epinephrine (see Fig. 22).

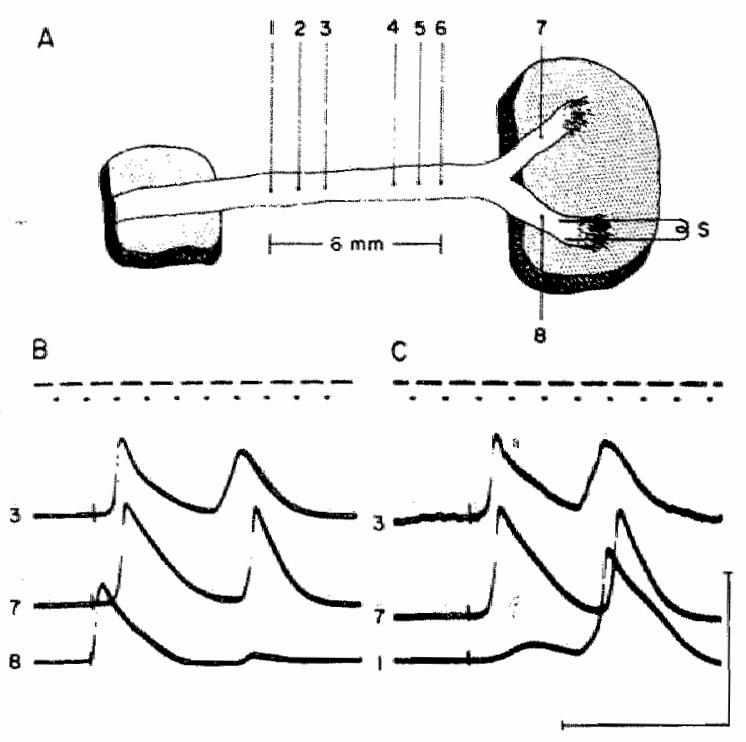

FIGURE 22. A shows the preparation thom whoth the

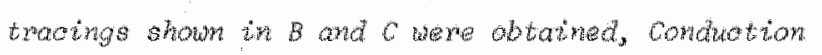

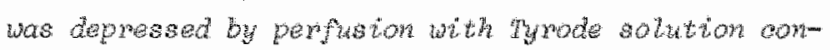

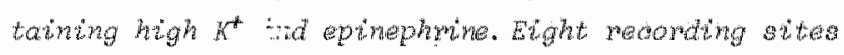

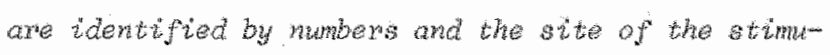
lating eleetrode to labeled s. Whe recordo show in B were obtained from sites 3 (top), 7 (midale) and

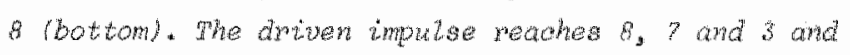

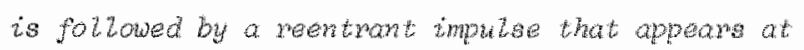

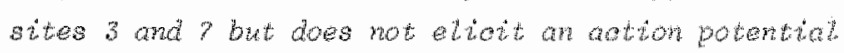

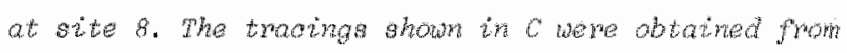

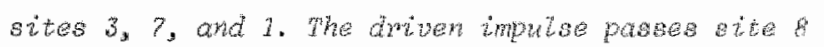
to reach site 3 but is blocked beforit it reaches atwe

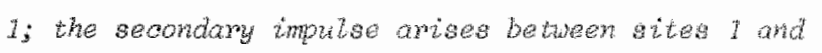
3 , traveling formand to site 1 and retrogmade to aties 3 and 7 . In $B$ and $C$ the time math appear at

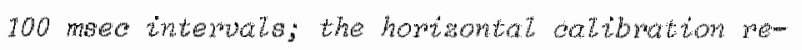
presento 500 mecos; the vertical, 100 my from; wit et az. 1973, al.

The same authors succeeded in directly demonstrating sustained circus movement in closed loops of fibers of the ventricular conducting system of canine or bovine hearts, measuring only 20 to $30 \mathrm{~mm}$ in length. Fig. 23 shows the preparation and the multiple microelectrocie recordings from the experiments of wIT et al. $(1972$ b). The network of Purkinje fibers and myocardium, taken from a calf heart, was depressed by a 15 -minute exposure to $15 \mathrm{~mm} \mathrm{~K}^{+}$followed by the addition of 5 $\times 10^{-6} \mathrm{M}$ epinephrine. Three intracellular recordings are shown, recorded arouna the loop (sites 1, 2, and 3). The first set of action potentials were elicited by a stimulus applied at $\mathrm{S}_{1}$; the second group arose from a premature stimulus applied at $\mathrm{s}_{2}$ and the rest resulted from reexcitation via circus movement without further applied stimuli. In the diagrams at the bottom the sequence of activation is drawn schematically. Panel A shows the path of the driven impulse that arises at $s_{1}$. In $B$ is shown the path of the premature impulse elicited at $s_{2}$. The prenature impulse is blocked in one branch and travels from 3 to 2 to 1 , making a complete circus in a counter clockwise direction. On returning at site $s_{2}$ the impulse reenters site 3 and continues in the circuitous pathway to sites 2 and 1 and 
so on around the ring, for a total of seven circuits.
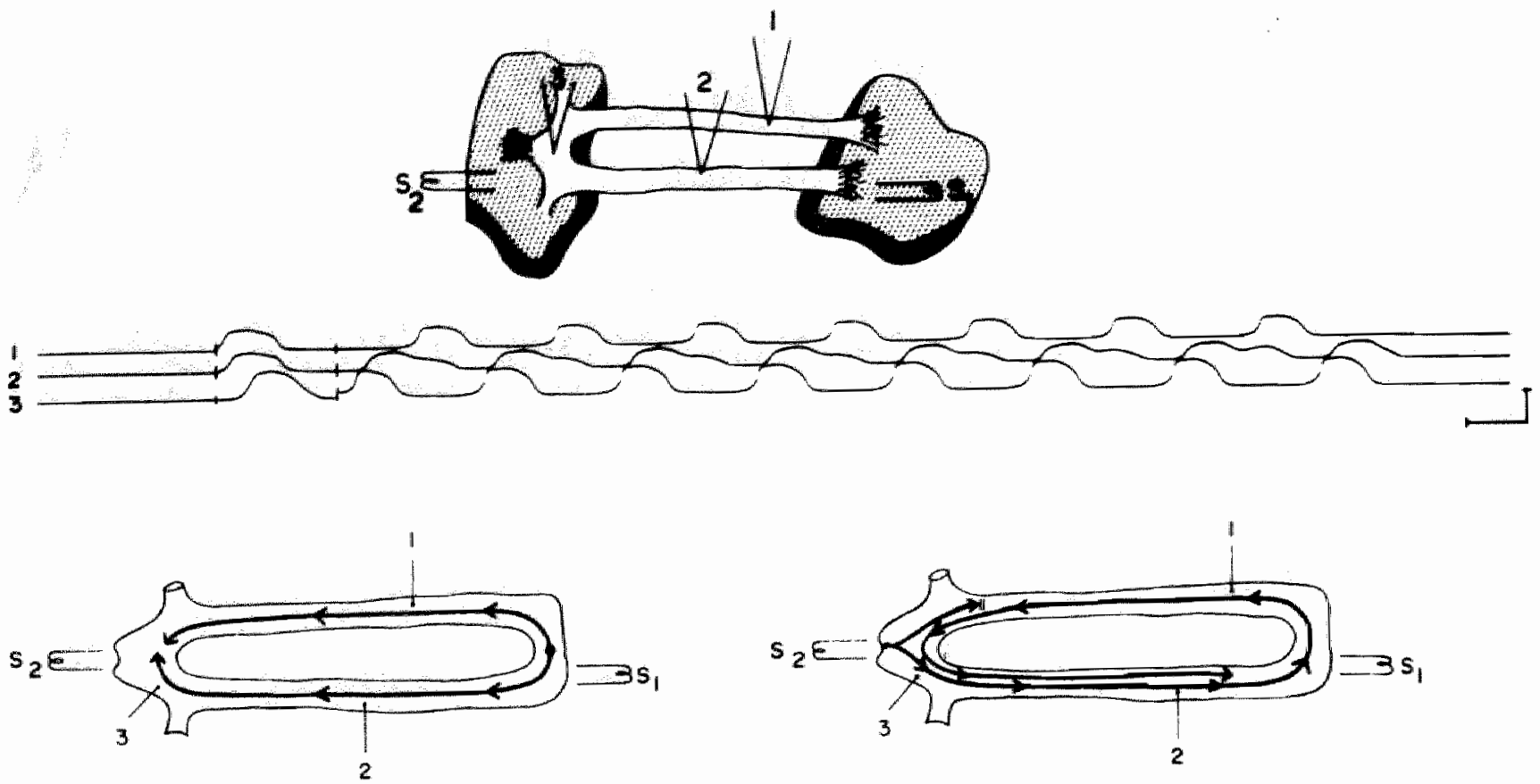

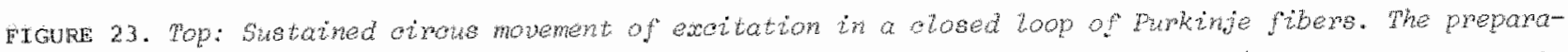

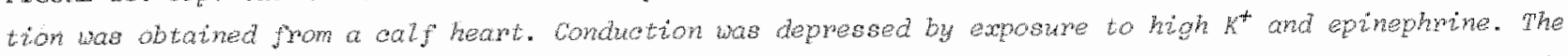

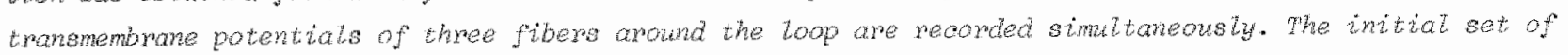

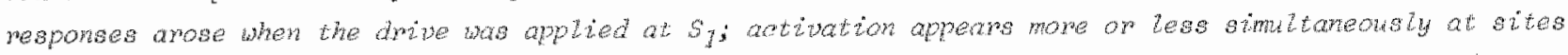

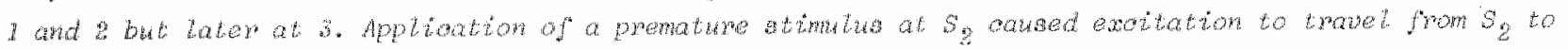

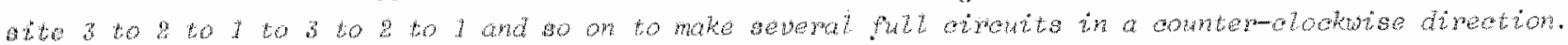

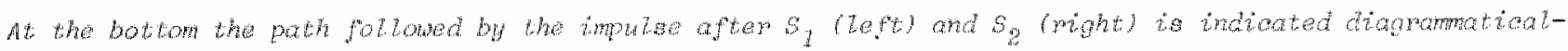

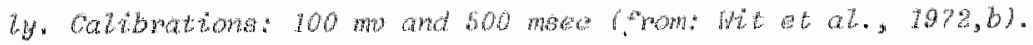

Dangerous arrhythmias in the ventricles may occur during the very first stage of myocardial infarction. Unfortunately, our knowledge of the mechanism of these arrhythmias is still very limited. As to the possible role of reentry in the acute stage of myocardial infarction, interesting experiments have recentIy been performed by DOWNAR et al. (1970 a, b) and JANSE and DOWNAR (1977). Using flexibly mounted microelectrodes, they followed the changes in transmembrane potential recorded from the subepicardium of both in situ and isolated intact pig's hearts immediately after coronary acclusion. Fig. 24 gives an example. During the experiment, heart rate was kept constant by artificial pacing with an interval of 390 msec. Rapidly after coronary occlusion, the action potential shortened, and its amplitude and upstroke velocity diminished. Furthermore there is a progressively increasing delay of activation and loss of resting membrane potential. 
After 9 minutes of ocolusion, alternation occurs, whereas after 12 minutes of ischemia the fiber got irresponsive.

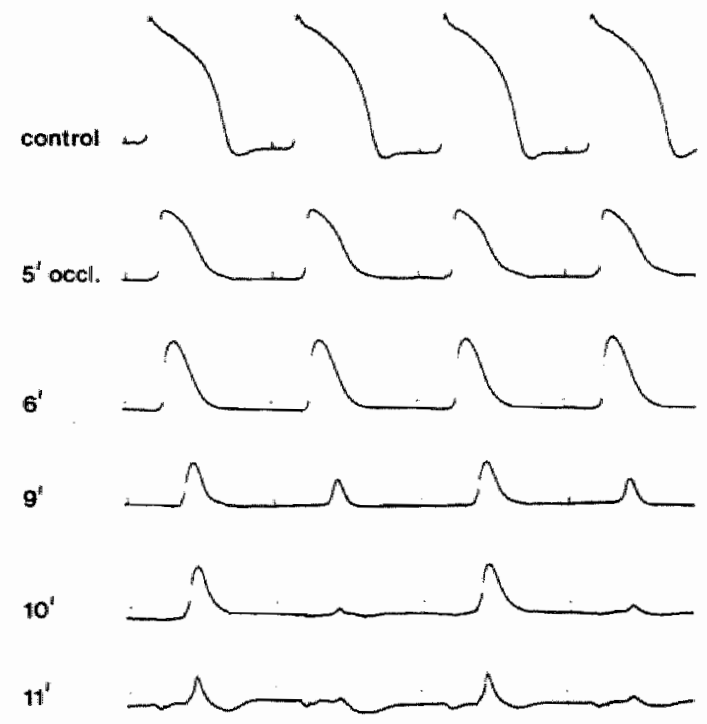

FIGURE 24. Thansmembrame potential of a subeptomeni-

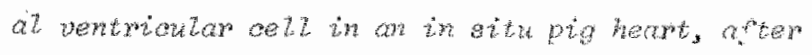

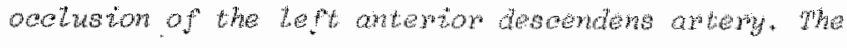
ventriche was paced at a cyole tength of 390 mace. Action potentral duration was progresstuety shortened and caplitude and upstroke velowity graduathy reduced

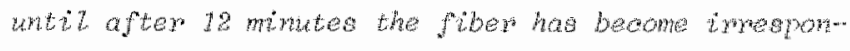
sive (from: Downar et al., 1977b).

Ventricular arrhythmias, especially ventricular fibrillation, were, seen most frequently during (1) the period of 5 to 10 minutes after onset of ischemia and (2) the period immediately following reperfusion. During both these periods, markedly depressed conduction was present together with great inhomogeneity in refractory periods in closely adjacent areas. This is illustrated in Fig. 25. The figure shows two simultaneously recorded action potentials during the development of ischemia. Stimuli were applied close to the cell of the lowex trace in each panel. During control, the local refractory period was 234 msec. During ischemia refractory period progressively shortened to 140 msec. The Iower panel strongly suggests that in the small area surrounding the stimulating electrode the fibers had markedly different refractory periods. A test stimulus given after $140 \mathrm{msec}$ did not excite the lower cell; however, other elements in the vicinity of the stimulating electrode must have recovered their excitability as can be concluded from the fact that the upper cell was activated by the premature stimulus. The lower cell was excited only after a very long interval and the ensuing ventricular fibrillation may have been due to reentry initiated by the local inhomogeneity in spread of activation of the premature beat. Although it is. of course, impossible to demonstrate a circuitous pathway of the impulse with only two microelectrodes, this experiment of JANSE and DOWNAR (1977) clearly demonstrates that during the very early stage of myocardial infarction all circum- 
stances are in favour of reentry. Slow conduction, short refractory periods, inhomogeneity in refractory periods in closely adjacent areas and the occurrence of unidirectional block, it is all that can be desired for the production of zeentrant ventricular tachycardia and fibrillation.

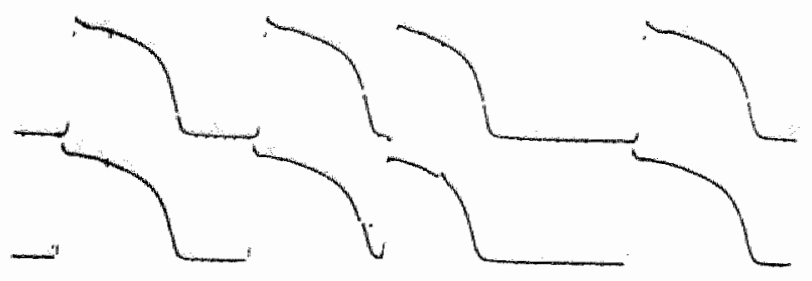

control $\quad s_{1} s_{2} 234$

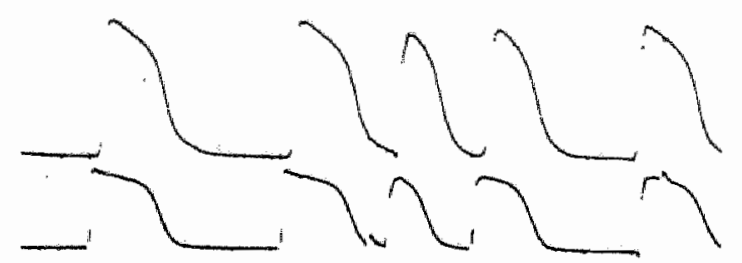

$4 \mathrm{~min} \mathrm{occl.} \quad \mathrm{S}_{1} \mathrm{~S}_{2} 185$
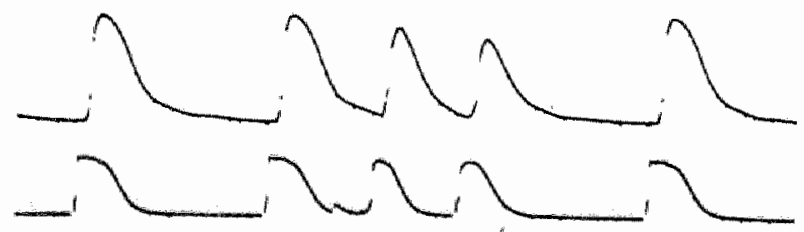

$5 \frac{1}{2}$ min occl. $s_{1} s_{2} 150$
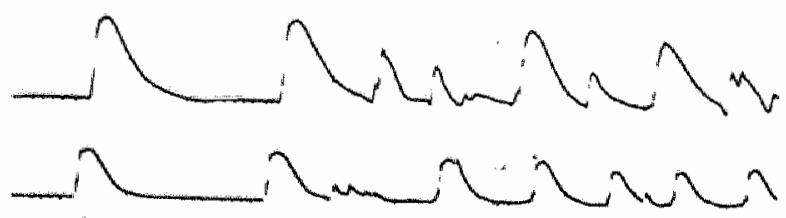

$6 \frac{1}{2} \operatorname{min~occl} s_{1} s_{2} 140$

FIGURE 25. Tho simultaneousty reconded action potentials from cells 1 an aport. Stimula weme applied atose to tower ce 22. Note shortening in pefmotory periods folzowing aorowary arwery ocolusion. Hote difference th laterigy of test atimul delivaned 185 and 150 meo after basic stimulu (2nd ard $3 x d$ paned. In towest panet the test pulse does not result in a regeneratue response in lower celt but must have exotted a more remote cell from

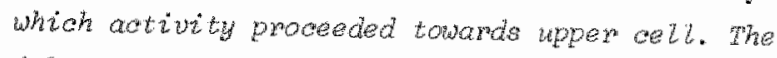
inhomogemeity in actuation may have been respon3tote for the ensung ventricula aotuation (from: Jonse and Dowman, 1977 ). 


\section{CIRCUS MOVEMENT WITH THE INVOLVEMENT OF AN ACCESSORY ATRIO-VENTRICULAR} PATHWAY

There is another group of reentrant arrhythmias which deserves separate description; that is circus movement in which an anomalous accessory pathway between atria and ventricles is involved. This type of circuitous impulse propagation was already predicted in 1913 by MINEs, after the existence of such anomalous connections between atrium and ventricles was demonstrated (KENT, 1892). After this first report of KENT, many cases have been described in which, either by anatomical studies or by electrophysiologicai evidence, anomalous pathways between atrium and ventricles have been demonstrated. Recently ANDERSON et al. (1975) have proposed a new nomenclature for the anatomical substrates underlying the varieties of the ventricular pre-excitation synarome. In figure 26 the classification of the different anomalous connections is given. Irrespective of the type of accessory connection or bypass tract, the principle of reentry in these cases is the same: the impulse is circulating in an anatomical defined circuitous pathway. The possible pathways based upon the different types of accessory connections found in the pre-excitation syndrome have recently been discussed by DURRER et al. (1970). Depending on the localization of the accessory pathway relative to the normal. A-V nodal- His pathway, the dimensions of the circuit can be eithex large or small. The cycle length of these tachycardas is determined by the total conduction time along this circuit. Slow conduction in the circuit and/or a long circuitous pathway will result in tachycardia with a relatively low frequency, whereas rapid conduction in a small circuit will cause tachycardia with a high rate. The development of programmed electrical stimulation of the human heart (WELLENS and DURRER, 1975) and endocardial and epicardial mapping procedures (DURRER and ROOS, 1967; GALLAGHER et al. "1976) have opened new roads towards identification of the pathway involved in an individual patient.

The chance of initiation of paroxysms of tachycardia is especially determined by the electrophysiological properties of the atrio-ventricular node and. the anomalous connection. If there exists large differences in refractory periods between the two atrio-ventricular connections, conduction block of a premature beat in one of the two connections may easily occur. On the other hand if the refractory periods of both pathways are more or less equal, the reentry zone 
TABLE I Definition of terms, indicating the morphological constitution of possible pathways

\begin{tabular}{|c|c|c|c|c|}
\hline Defintition & Subgroups & Types & $\begin{array}{l}\text { Morphological } \\
\text { origin and insertion }\end{array}$ & $\begin{array}{l}\text { Composition of } \\
\text { pathway }\end{array}$ \\
\hline \multirow{5}{*}{$\begin{array}{l}\text { 1. Accessory } \\
\text { conmections }\end{array}$} & \multirow{3}{*}{$\begin{array}{l}\text { A. Accessory atrio- } \\
\text { ventriculat miscle } \\
\text { bundilles }\end{array}$} & 1 Septal & $\begin{array}{l}\text { Atrial myocardum to } \\
\text { vemtricular myocardium }\end{array}$ & Myocardium \\
\hline & & $\begin{array}{l}\text { II Parietal } \\
\text { (specialized) }\end{array}$ & $\begin{array}{l}\text { Atrial myocardium to } \\
\text { ventricular myocardium }\end{array}$ & Specialized tissue \\
\hline & & $\begin{array}{l}111 \text { Parietal } \\
\text { (nonspecialized }\end{array}$ & $\begin{array}{l}\text { Atrial myocardium to } \\
\text { ventricular myocardiam }\end{array}$ & Myocardium \\
\hline & \multirow{2}{*}{$\begin{array}{l}\text { 13. Accessory nodo- } \\
\text { ventricular muscle } \\
\text { bundles }\end{array}$} & $\begin{array}{l}\text { I Overlay } \\
\text { (transitional) }\end{array}$ & $\begin{array}{l}\text { Transitional cells to } \\
\text { wentricular myocatdium }\end{array}$ & Specialized tissue \\
\hline & & $\begin{array}{l}\text { II Deep } \\
\text { (compact node) }\end{array}$ & $\begin{array}{l}\text { Compact modal cells to } \\
\text { wentricular myocardium }\end{array}$ & Specianlized tissue \\
\hline \multirow{2}{*}{ 2. Bypass tracts } & A. Atriofascicular fibers & & $\begin{array}{l}\text { Atrial myocardium to } \\
\text { penetrating bundle }\end{array}$ & Myocardium \\
\hline & B. Intranodal pathways & & $\begin{array}{l}\text { Alternate pathways through } \\
\text { junctional area }\end{array}$ & Specialized tissue \\
\hline $\begin{array}{l}\text { Fasciculo } \\
\text { veritricular } \\
\text { connections }\end{array}$ & & & $\begin{array}{l}\text { Ventricular specialized } \\
\text { tissue to wentricular } \\
\text { myocardium }\end{array}$ & Specialized tissue \\
\hline
\end{tabular}

\section{Transitional Cells Penetrating Branching \& Compact Node Bundle Bundle}

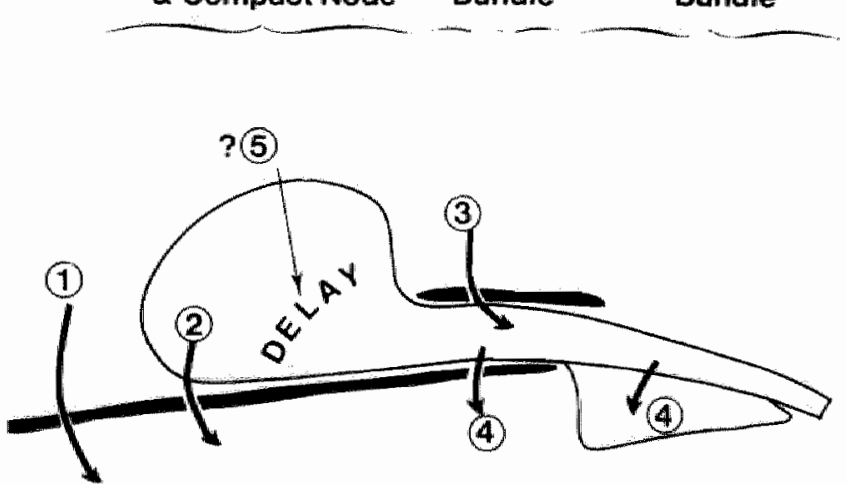

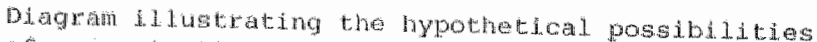
of prosuchation upon whoh the proposed nomenol tur is based. The dalay-produchng area hs lowidzed within the tranglonat orl aone and compact nodal areas

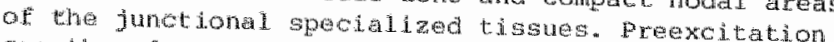
at therefore be produced (a) by an acressory musche bundhe originating and inserting an plain myocarium (1); (b) by a noglontencular musche bundle origunating from specialzed tisue wnd inserting in wentricular myocandum (2); (c) by an atelofascicular bypass twat insenting into the ponetrating bundle distap to

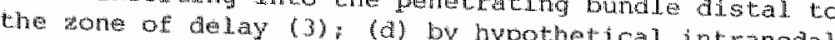
bypase traction (5) cate possibility labelled (4) indiCats the presence of fasciculoventricular ribers. Depending on thej site of takeoff, size and conduntion vidocity these fibexs could either themselwes produce sone anount of presextation by 'short-circulting' the ventricular conduction pathwys or could modify the electrophysiolocical behavion of a bypass ont the more proximaly possibility exists that could of of the junctional area. "This possibility is also bypothetical at the present time.

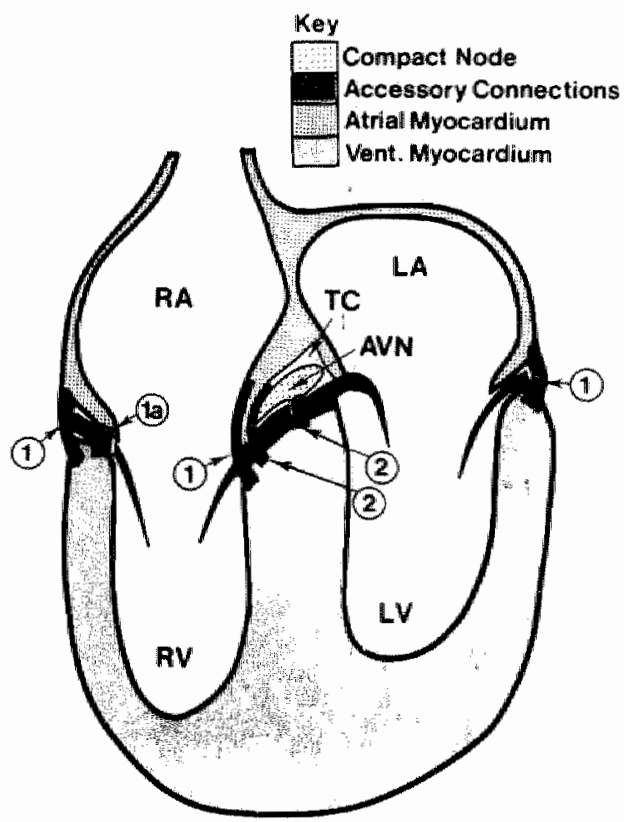

Diagm illustrating the various possible vaxieties of accessory conmetions. An accessory connection is detined as a comection INSERTING into plain ventricula myocerdilm. Two varieties are possible: (1) atrioventricular accessory conmections and (2) nodoventricular accessory connections. The variety (1) can be further divided into parietal and septal types. The parietal type can be composed or either specialized (la) or non specialized (1) masculature. The second variety (2) is divided into connctions between transitional celis (TC) and ventricular myocandium and the compact node (AvN) and ventricular myocaraium. The other abbrevia tions are as follows: RA - wight atrium, LA - left atrium; RV - right ventricler LV - lest ventricle. 
in which premature beats may initiate tachycardia can be very small. This may explain why many patients with pre-excitation seldom develop tachyarxhythilas based on a circus movement, while others seriously suffer from frequent attacks of tachycardia. It also offers a rational basis for phamacological therapy. Drugs which tend to bring the properties of the two pathways, especially the refractory periods, closer togethex, can be expected to decrease the frequency of attacks. However, one should realize that drugs may not have the same effect on conduction and refractory period of accessory pathway and A-V node- His pathway when $A-V$ and $V-A$ conduction are compared.

Another appraach is to bring the words of MINES into practice: "The best test for a circulating excitation is to cut through the ring at one point.... the vigorous circulating wave and its instantaneous arrest by section of the ring is a sight not easily forgotten". During surgery one can try to localize the anomalous connection by mapping the epicardial activation times along the $A-V$ sulcus and then try to interrupt the accessory pathway by making a local incision along the atrio-ventricular groove, or, if the accessory pathway cannot be identified, one can try to cut the bundle of His. However, as pointed out by DURRER and WELLENS (1974): "This is a major undertaking, an ultimum refugiens which taxes the skill of the surgeon, the electrophysiological capacities of the cardiological team, and their ability to rise to the challenge of unexpected situations, which do occur all too often". This situation is a typical example of the necessity of close cooperation and electrophysiologic orientation between surgeon and cardiologist. 
CIRCUS MOVEMENT IN THE ATRIO-VENTRICULAR NODE

The A-V node plays a crucial role in the normal and abnormal activation $0=$ the heart. Not only that the conduction of the $A-V$ node is slow and its morphologic and electrophysiologic properties are rather complex, but also its position Wh respect to the other parts of the heart is unique in that it forms the only electrical connection between the atria and the ventriries. This special axrangement of the $A-V$ node has made it possible to acquire mun information about the Function and behaviour of the node, using indirect methods. Regarding the A-V junctional area as a "black box", detailed analysis of input/output relations 'Ising His bundle recording and electrical stimulation of the atria and the ventricles, has been successful in describing mechanisms operative in the human $A-V$ node, which in some cases could be confirmed with more direct techniques in animal experiments.

One of the most important contributions to our understanding of cardiac arrhythmias, is the demonstration of functional longitudinal dissociation as a property of the normal A-V node. Evidence for such dissociation first has been accumulated by analysis of the temporal relations between atrial and ventricular activation during premature stimulation (MOE et al., 1956). Later the presence of a dual $\mathrm{A}-\mathrm{V}$ nodal conduction system could be directly demonstrated in isolated but otherw se normal rabbit hearts (MENDEZ and MOE, 1966). In figure 27 the concept of intranodal longitudinal dissociation is represented schematically. The upper part of the node is thought to be functionally and spatially dissociated into two pathways, the so-called alpha and beta pathways. Both pathways are considered to have different electrophysiologic properties especially with respect to refractory period and conduction velocity. Somewhere between the atrium and

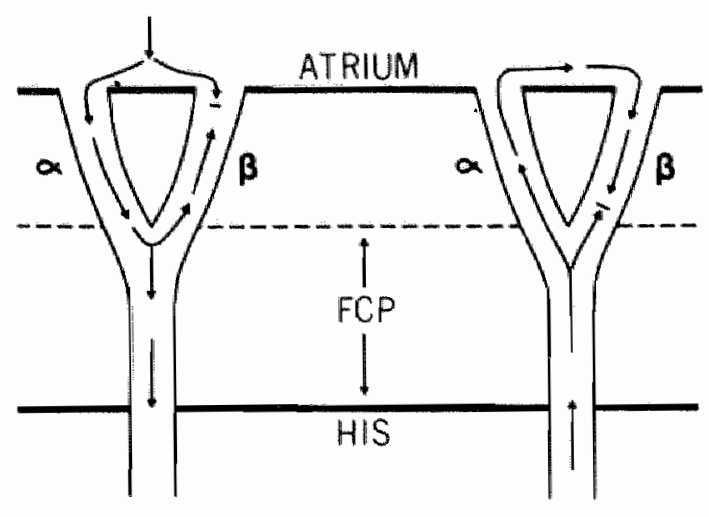

FIGURE 27. Schematio representation of intranodal dissociation. The diagram to the teft iturtrates the sequence of avents dumg an atrial echo. A prenature atrial response fails to penetrate the 8 path but propagates through the a pathway. Onee the final comon pathway (FCP) is engaged, an echo maty retum to the atwium wia the now recovered 8 pathway. The diagram to the might 22 Lustrates the patterm of propagation duwing a ventritalar echo. A premature response in the He bundte traverses the FCF, finds the B pathway stith refractoxy from the previous exoitation, reaches the atriam over the a pathway, and retwms through the now recovered $B$ limb (from: Mendez and Moe, 1966). 
the His bundle these pathways come together to form a final conmon pathway (FCP) which passes into the bundle of His. This duality in the A-V transmission system has become the basis for the explanation of both atrial and ventricular echo beats and supraventricular tachycardias arising in the atrioventricular junction. The diagrams of figure 27 illustrate the supposed sequence of events underlying an atrial echo beat (left) and a ventricular echo beat (right). An atrial premature beat is blocked in the beta pathway whereas it contimues to propagate along the alpha pathway. Once the final common pathway (FCP) is reached, the beta pathway, which now has regained its excitability, is invaded retrogradely. If the impulse reaches the site of antegrade conduction block at a moment that the fibers proximal to the block have restored their excitability again, the impulse may return to the atrium as an echo beat.

A ventricular premature beat, reaching the bifurcation of the final common pathway, may equaliy find the beta pathway still refractory from the previous excitation; as a result the atrium is activated exclusively via the alpha pathway and the way is free for a return of the impulse to the ventricles through the now recovered beta limb. Later studies have shown that, at least in some cases, the atrium forms no obligatory link in the pathway and that a circuit is possible within the $A-V$ node itself (MIGNONE and WALIACE, 1966; JOSEPHSON and KASTOR, 1976).

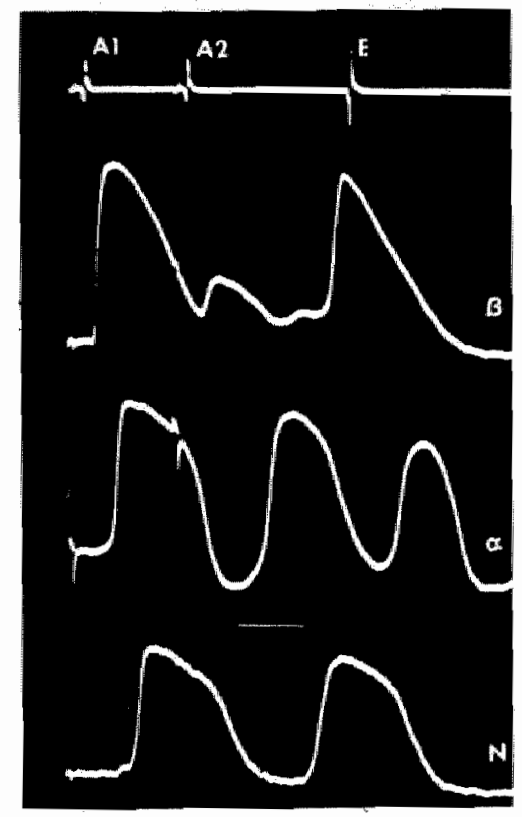

FIGURE 29. Composite reaord including action potentials of units in $\beta$, a and N regione. Desoniption th text. Time calibration equals $50 \mathrm{mbed}$ (from: Mendes and hoe, 1986 ). 
Figures 28 and 29 provide substantial evidence for this concept. In figure 28 an atriun electrogram 13 shown together with action potentials of units in $B$, $\alpha$ and regions (the $N$ region of the node is part of the FCP). The traclngs show the responses to the basic stimulus $\left(A_{1}\right)$ and a premature stimulus $\left(A_{2}\right)$ applied to the right atrial roof. The basic stimulus activates both and $B$ pathways as well as the FCP as exemplified by the $N$ record. The premature $A_{2}$ caused only a local response in the $\beta$ cell, whereas propagation along the $\alpha$ pathway and $\mathrm{N}$ cell was successful, although conduction was considerably delayed. The $B$ cell then showed a reciprocal response about $25 \mathrm{msec}$ after the premature $\mathbb{N}$ response; shortly thereafter the atrial echo was recorded. A third response, reduced in amplitude, appeared in the $\alpha$ cell following the atrial echo; this was not propagated to the $\mathrm{N}$ cell and thus must be considered as abortive.

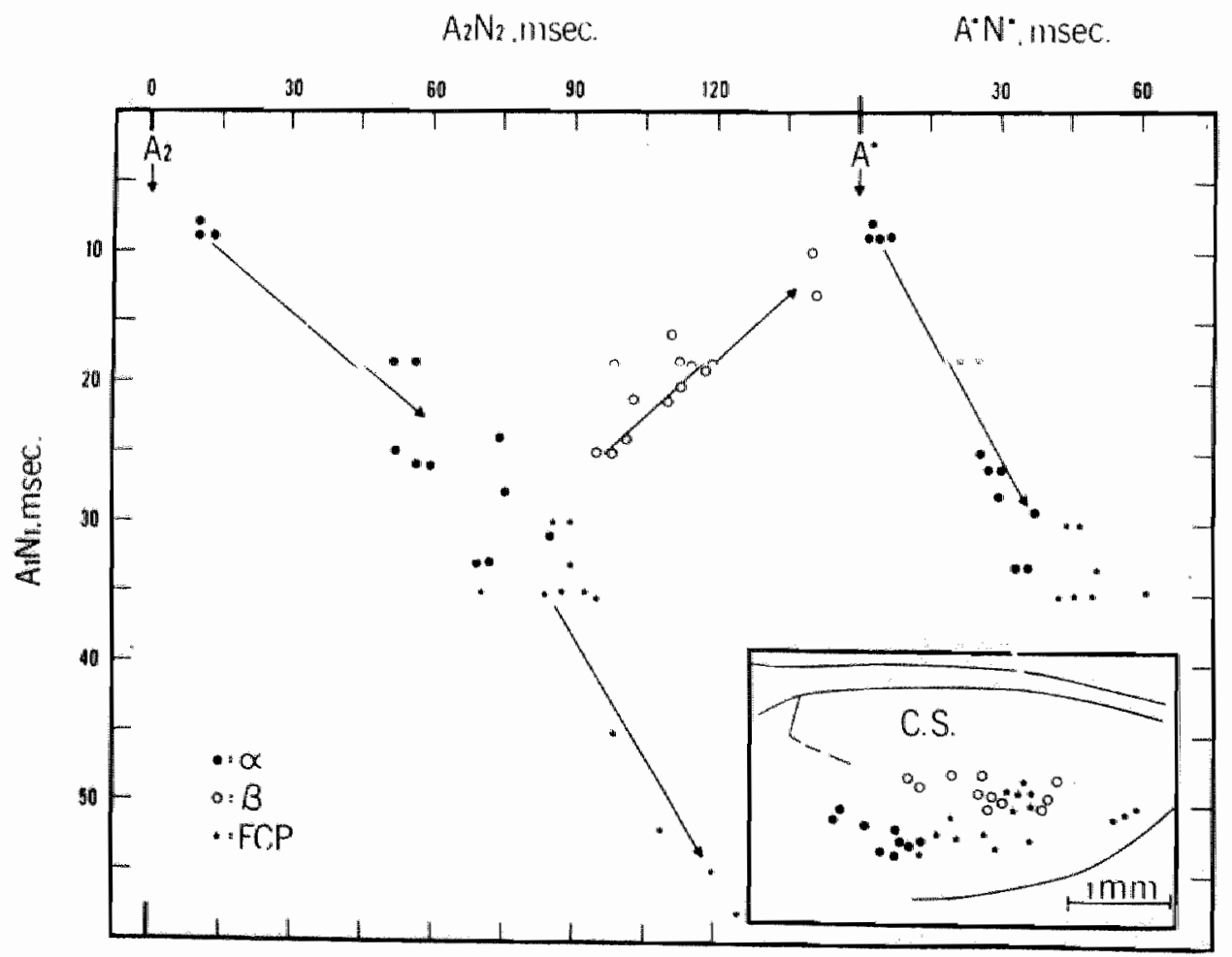

Fugure 29. Anatomic and temporal relationship. "Time-distance" plot recorded at 35 pumoture sites dining passage of a premature $A_{g}$ response, its echo (A*), and an abortive re-echo. Vertical time scale: conduction time from $A_{1}$ to the impaled nodal cels, $N$, in meec. Howizontal scale, conduction time from $A_{2}$ to nodal ceth, adjuted to the average $A_{Z^{*}}$ interval (150 mseol. To the right of $A^{*}$, conduction time of reecho in imsec. Anatomic position of points indicated in inset sketch. Circled stars indicate site whe re

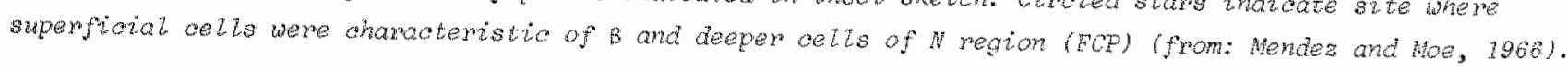


Figure 29 shows the anatomic and temporal relationship of 35 difforont fibors from the $A-V$ node during the occurrence of an atrial echo. Tho position of each fiber is indiceted on the ordinate as the time interval between the atrial complex and the corresponding action potential of the fiber auring basio rhythm $\left(A_{1} \mathbb{N}_{1}\right)$. The vertical axis, al though expressed as time, thus can be taken as an arbitrary distance scale. On the abscissa the moments of activation of the same

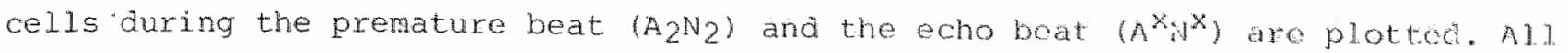
three pathways ( $\alpha, \beta$ and FCP) could be clearly identifind, cach rathwy bojng represented by a relatively large number of fibers. The fibers belonging to the w pathway are plotted as solid circles, the oben symbols robrosmt numonts of the $B$ pathway, while the fibers in the final common pathway aro aosignated by astorisks. The anatomic position of the different pathway are incicatod in the insot sketch. These expeximents provided the necessary airect domonstration of longltudinal association in the $A-V$ junction; it formed the basis for our presont understanding of atrial and ventricular echo beats and custained $n-v$ nomol tacliycardias.

MENDEZ and MOE (1966) also observed multiple reciprocal rosonses. Nithough they did not succeed in directly tracing the pathway of the impulse during snch sustained nodal tachycardia, indirect evidence strongly suggested that this rapid rhythm was also based on reentry within the $A-V$ node (wir ot al., 1971). Jhero is only one example in literature in which nearly the complete pathwa of the inpular through the $A-V$ node during such a steady state tachycardia could bs rollowed (JANSE et al., 1971). These authors used a "brush electrode" consisting of 10 conventional microelectrodes, which were inserted. simultaneously in the $A-V$ nodr. of an isolated preparation of the rabbit heart. The ten microelectrodes voro glued closely together, the tips being situated within a surface of $1.5 \times 0.7 \mathrm{~m}$. With this technique, the moments of activation of 54 nodal cells could be dotermined during a sustained tachycardia, which was initiated by the incuction of a single properly timed atrial prenature beat. Figure 30 shows the initiation of the tachycardia. In the upper part of the figure the applied stimuli, the atrium electrogram, and simultaneous recordings of transmembrane potentials of six A-V nodal cells together with a His bundle recording are shom; the midale portion gives a ladder diagram of the sequence of activation of the fibers, while the sketch at the bottom shows the position of the cells. During basic rhythm the sequence of activation of the nodal elements is from $N_{1}$ to $\mathbb{N}_{6}$. During the 

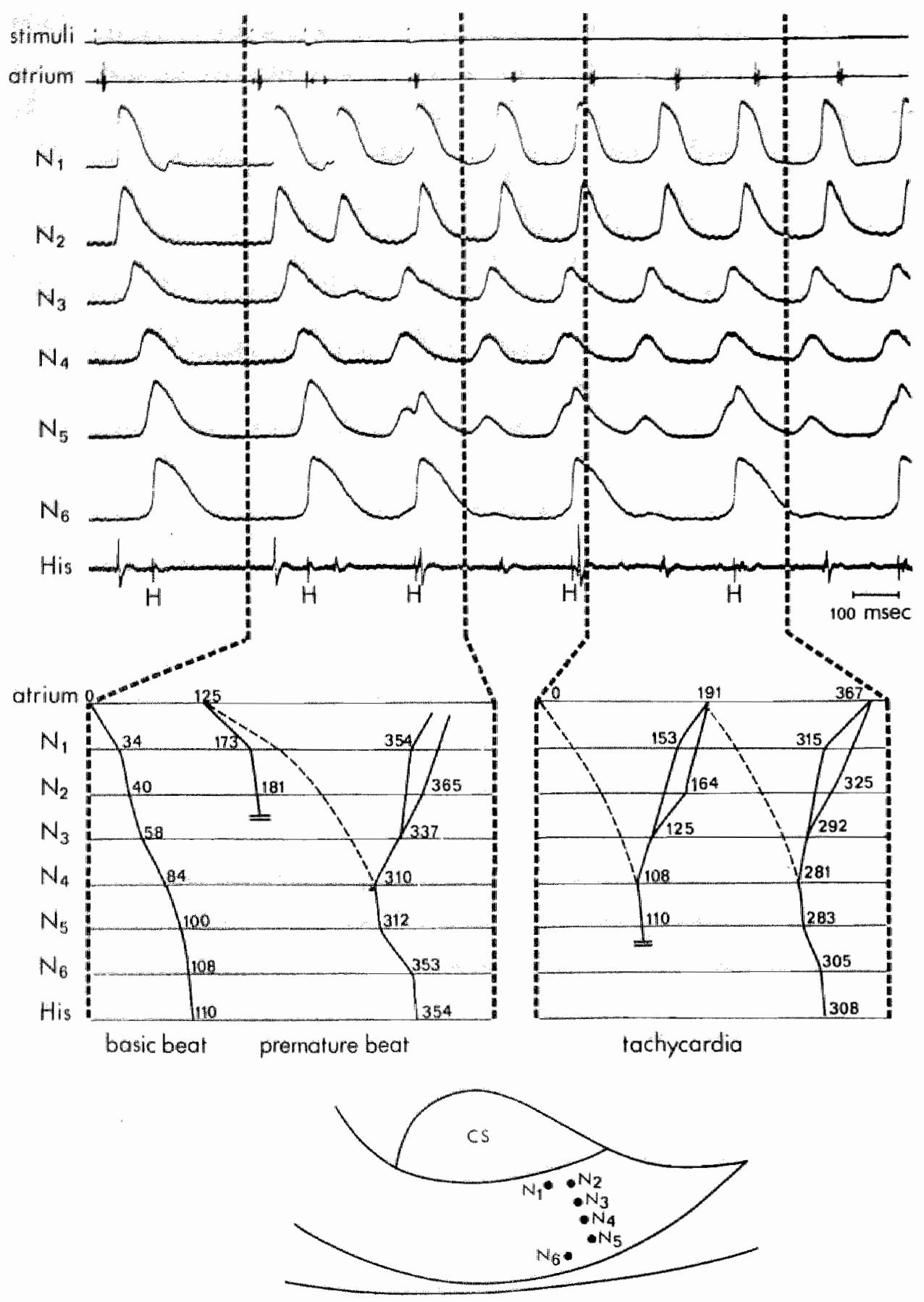

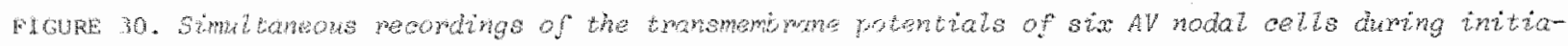

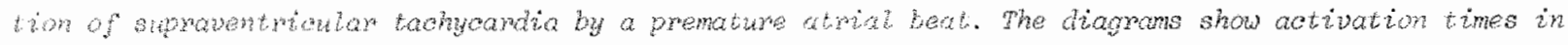

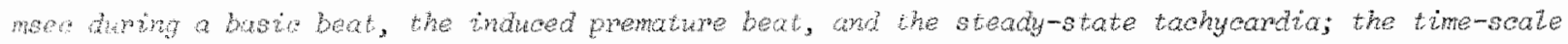

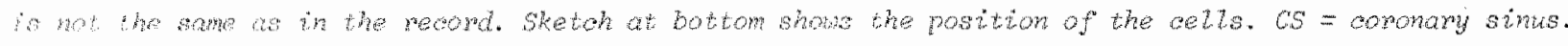

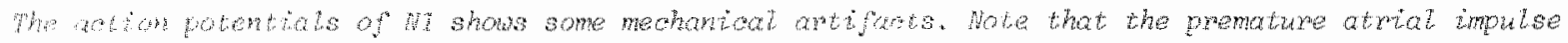

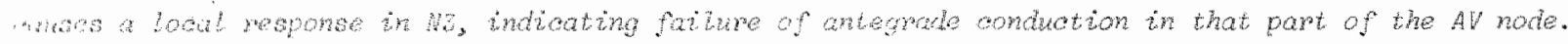

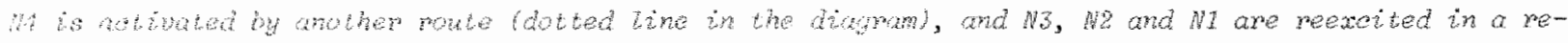

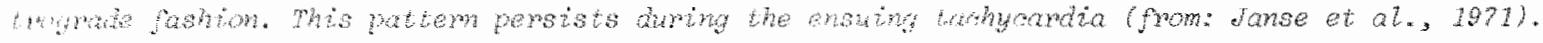


propagation of the premature beat this order has completely changed. Antegrade concuction o: the premature impulse is blocked along fibers $N_{1}$, 2 , as can be seen from the local response in cel $\mathrm{N}_{3}$; apparently these fibers belong to the $B$ pathway. Fihers $\mathbb{N}_{4}^{-6}$ are activated with great delay, evidently because they are reached via the a pathway. The $N_{4}$ action potential is followed by extra non-stirulated action potentials in $\mathrm{N}_{2}-3$ which are now excited in a reverse order compared to the basic beat. During the following period of tachycardia there was $2: 1$ block to the fibers $N_{5}, 6$ and to the bundle of His. Fibers $N_{1}-3$ were activated in a retrograde direction. Figure 31 gives the time measurements of all 54 impaled fibers during this period of supraventricular tachycardia with $2: 1 \mathrm{~A}-\mathrm{V}$ block.

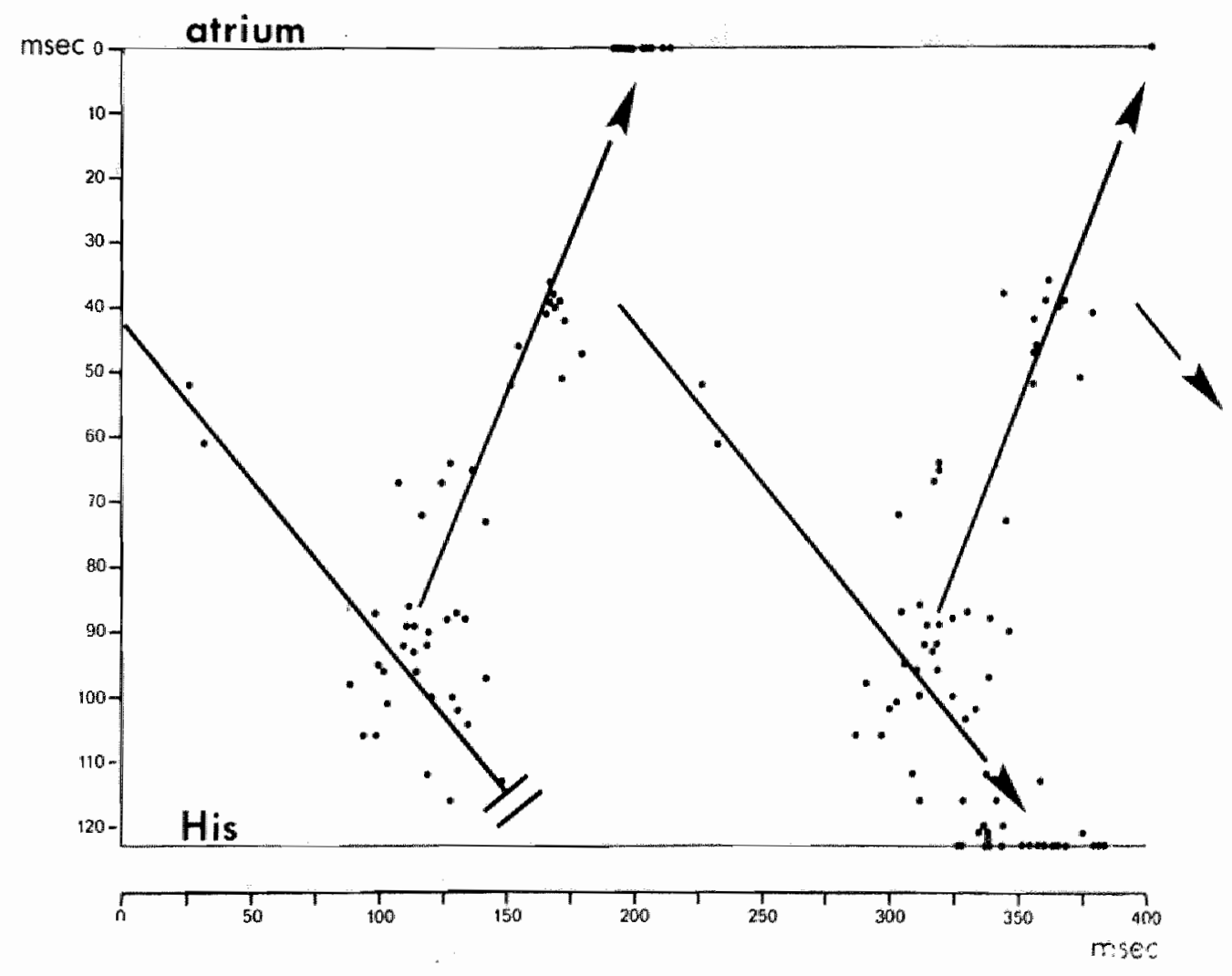

FIGURE 31. Moments of detivation of 54 AV modal cells during steady-state tachyeardia. Time scale on the ordinate indicates the temporal position of the AV nodal cells during a basto bect when the atrium was driven regularly (t $=0$ is the atrial compiex). Time soole on the abscissa indicates the temporat posttion of the same celts during steady-state tachycardia $(t=0$ is the atrict complex not followed by a His complex). Note the difference in activation times during tachycurdia in cells which, during a baic beat, are activated between 50 and 60 msec (modified from Janse et al., 1971). 


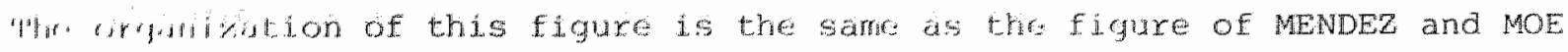
whili whol the pathway of the impulse through the A-V node during an atrial whi, (momare Fig. 29). The time sade on the ordinate gives the moments of actiwilon of the different Elbers auring basic rrythrind can be interpreted as aisthance (t=o is atrium, $t=120$ is His bundlei). The absoissa indicates the temporal position of the same cells during the steady state tachycardia. phe atrial complsz which was not followed by a His complex was chosen as zero time. The majority of the recorded fibers belonged to the retrograde and final common pathwy; only two cells were impaled lying on the antegrade pathway. Nevertheless this experiment goes as far as one possibly can go. Together with the results of MenDez and MoE (1966) it should be considered as the most dixect demonstration and most conclusive proof of circus movement within the $A-V$ node.

The question should be discussed whether the longitudinal dissociation of the A-V node is based on cextain specific anatomic pecularities or whether this phenomenon is solely due to differences in electrophysiological properties within the $A-V$ node. In 1966 MENDEz and MOE statcd thet the histological and electrophysologic state of knowledge of the A-V node at that time did not penit a conclusive choice. Nevertheless, they suggested the presence of two anatomic distinct pathways: "The area between the a and $B$ pathway (about 0.3 to 0.5 mm ar $105 s$ appeared to be electrically inactive, or was overlan by a barrier of connective thaue which prevented penetration of deeper and possibly active tissue. Grossly, this area appears as a whitsh streak which overlies the inferior margin of the soronary sinus orifice, or the site of the coxonary venous valve. ceis of the pathway were usually found supexior to this landmark and cells were zoma below

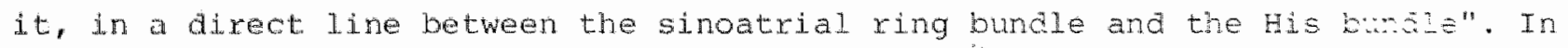
1971 JANSE at a1. still hesitated to make a choice: "It is duite pos=:

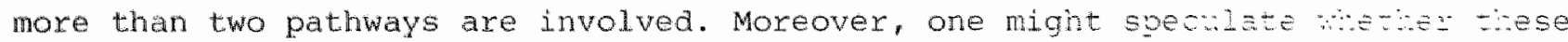
pathways are completely determined by their anatomical position.

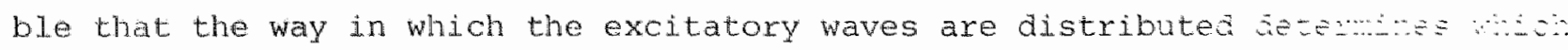
cells become a pathway and which cells $B$ pathway".

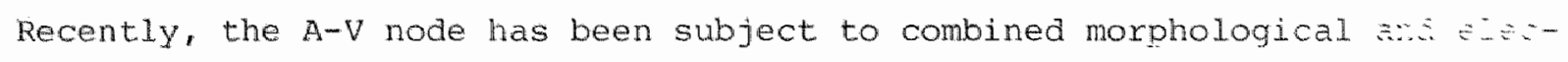
trophysiological investigations (BILETPE et al., 1976; ANDERSON et a1., 1974, 1975). These studies have revealed several possibilities for multiple anatomic pathways in the $A-V$ nodal area. First of all, there are distinct inputs to the A-V node. The atrial septal myocardium surrounding the $A-V$ node, is split into 
muscular bands by the orifices within the septum (Fossa ovalis, inferior vena cava, and coronary sinus). Thus three main bands approach the Eibrous annulus. An anterior band from in front of the fossa ovalis, a midale band between the fossa ovalis and the coronary sinus, and a third main band beneath the orifice of the coronary sinus, forming a muscular bundle in the atrial margin of the tricuspid valve septal cusp. The latter bundle is in direct communidation with the inferior extension of the crista texminalis (see figure 32).

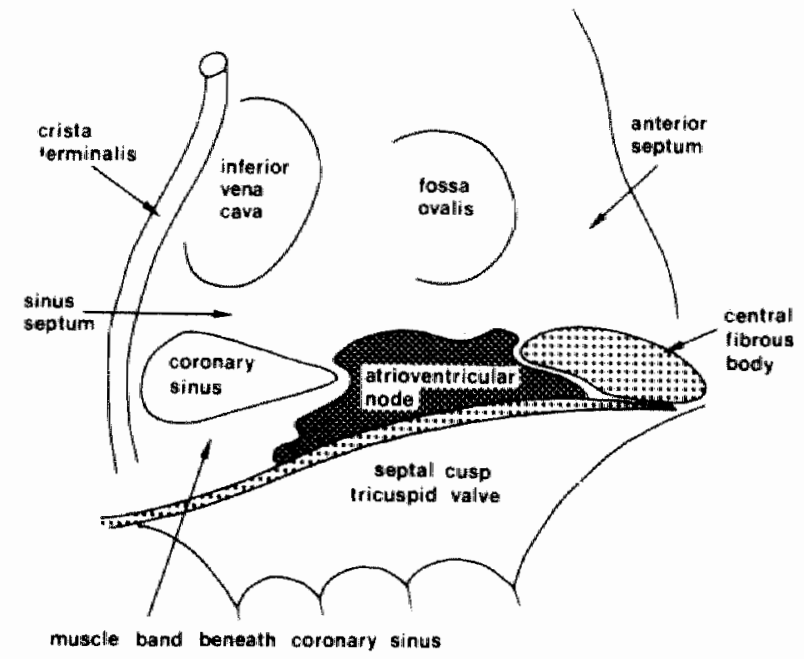

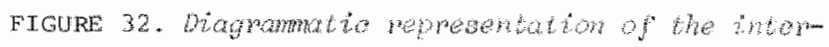

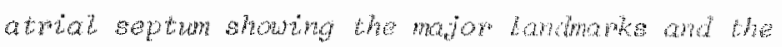
area ocowied by the spectalised thasues of the atritoventritudar node. The appradites th the male are dethineated by the presende of thee holes within the

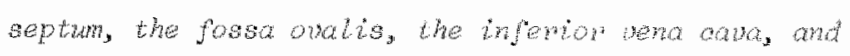

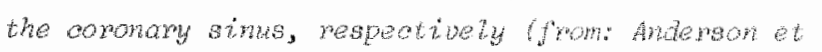
a.t., 19741 .

Histologic examination of the $A-V$ junction further revealed that these three atrial inputs make contact with three distinct groups of tranetionat aethes in the $A-V$ node (anterior, middle and posterior group, see Eigure 33).

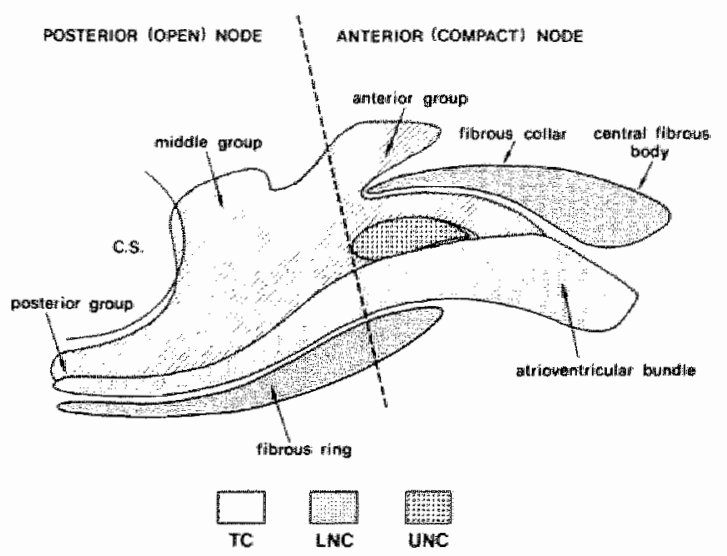

EIGURE 33. Dagmandite repregentation of the Aly

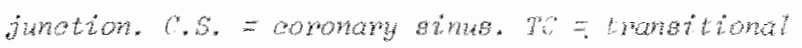

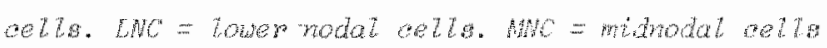
from: Andergon at at., $197 \mathrm{t}$. 
These toanstional cells are smaler in size than atrial fibers and show a pale staining reaction; the strands of transitional cells are separated by fibrous septa, wheh are not seen elsewhere in the node and indeed axe a major criterion in recognizing transitional cells.

Furthernore, there is the tendon of Todaro. In man, this structure extends backwards from the fibrous collax into the sinus septum, i.e., between coronary sirus and interior vena cava. The transitional cells join with atrial myocaraium above and beneath this structure. Maybe it is not pure coincidence that in this transitional cell zone, where multiple barriers at the microscopic level exist, signs of longltudinal dissocjation have been recorded (BILLETTE et al., 1976; ANDERSON et al., 1974).

Also at a lower level in the atrioventricular junction local block and reentry seem possible. TRANUM-JENSEN (1976) showed that the midnodal zone is composed of tightly packed celis which have a paucity of nexus connection. The cells form a "hole" in the part of the node that is enclosed in the fibrous collar, i.e., the final comon pathway. BILIETTE et al. (1976) found dissociation in activation in this area.

In conclusion one may say that the complexity in architecture of the $A-V$ junction offers ample opportunity for fragmentation of the activation wave: it may give a plausible explanation for the fact that the A-V node is a seat of predeliction for reentrant axrhythmias. However, further study of the properties of circus movement with and without the irvolvement of anatomic obstacles seems required before a definite answer can be given. 


\section{CIRCUS MOVEMENT IN THE SINO-ATRIAL NODE}

After the possibility of reentry in the sinus node was first suggested by BARKER et al. In 1943, in 1960 HOFFMAN and CPANEFIELD gave a more elaborate concept of sinus node reentry: "If the normally low conduction velocity is further reduced and local'blocks are present, the following sequence of events may ensue: Excitation initiated in one part of the node may cause normally propagated activity in the atrium. This atrial activity will rapidly reach and excite some other area of the sino-atrial node. Activity will then spread slowly over some pathways in the node and recxcite the atrial muscle shortly after the end of its effective refractory period. A mechanism of this sort may cause either coupled beats, a coubling of the normal rate, or complete irregularity. A conclusive demonstration of this sequence of events would require many simultaneous records of transmembrane potential at different locations and is not presently available. However,... coupled rhythms in rabbit and cat atria have often been observed under conditions associated with depression of nodal activity..... such coupled rhythms are most frequently associated with only a minor change in the sequence of activation of the atrium, suggesting that the initial sites of excitation for both the nomal. and coupled beat are quite close to the sino-atrial. node". In the last years a number of clinical reports appeared in which sinus node reentry was suggested to underlay atrial echo beats and supraventricular tachycaraia in man (CHILDERs et al., 1973; PAUIAY et al., 1973; NARULA, 1974; wU et a1., 1975). In contrast few studies have been done to test this hypothesis (HAN, MALOzzI and MOE, 1968). W1 th only a single microelectrode at hand these investigators have attempted to fol low the pathway of the activation wave within the sinus node after the induction of an atrial premature beat. In Fig. 34 the results of HAN, MALOzZI and MoE are given.

The isolated right atrium of the rabbit was driven at a slightly higher rate than the spontaneous rhythm by basic stimuli $\left(S_{1}\right)$, applied at the atrial roof. After each tenth basic stimulus an early premature stimulus $\left(S_{2}\right)$ was administered at the same site. In the present experiment an atrial echo could be produced repeatediy when $S_{2}$ was applied about 110 msec aftex $S_{1}$. In the time that reciprocal responses were stable, 18 different fibers, both in the sinus node and in the neighbouring atrial tissue were impaled. The time relations between these 18 different puncture sites could be detemined during basic rhythm, the premature beat and the reciprocal response. In the figure only 5 areas are indicated, 


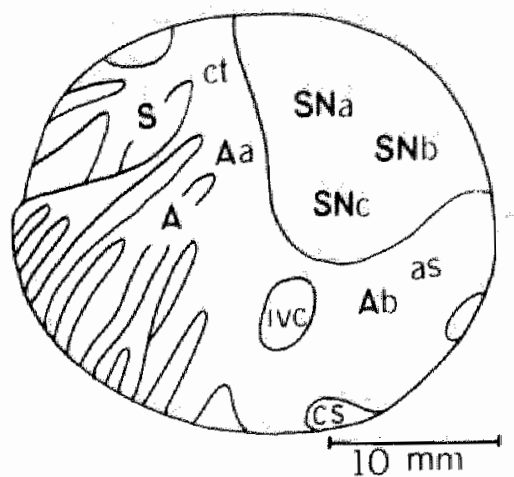

A

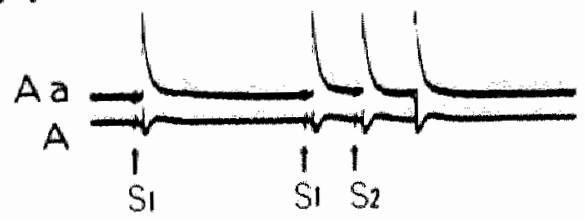

B

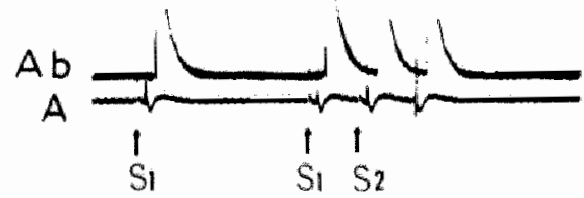

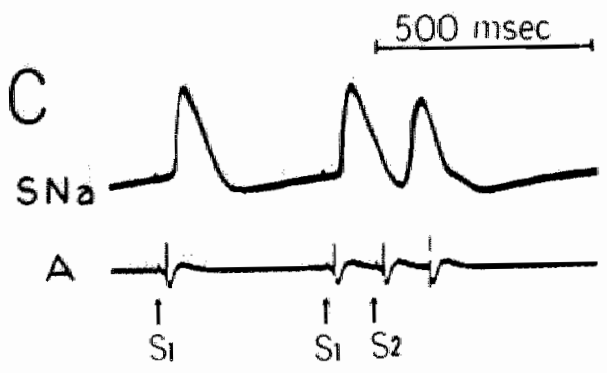
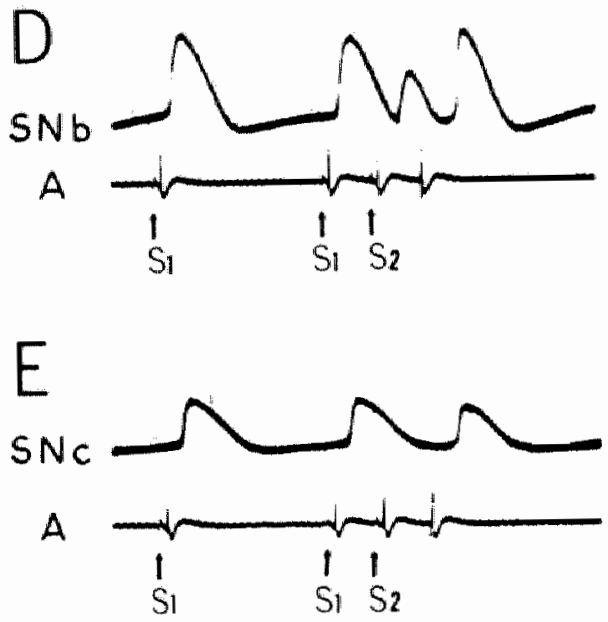

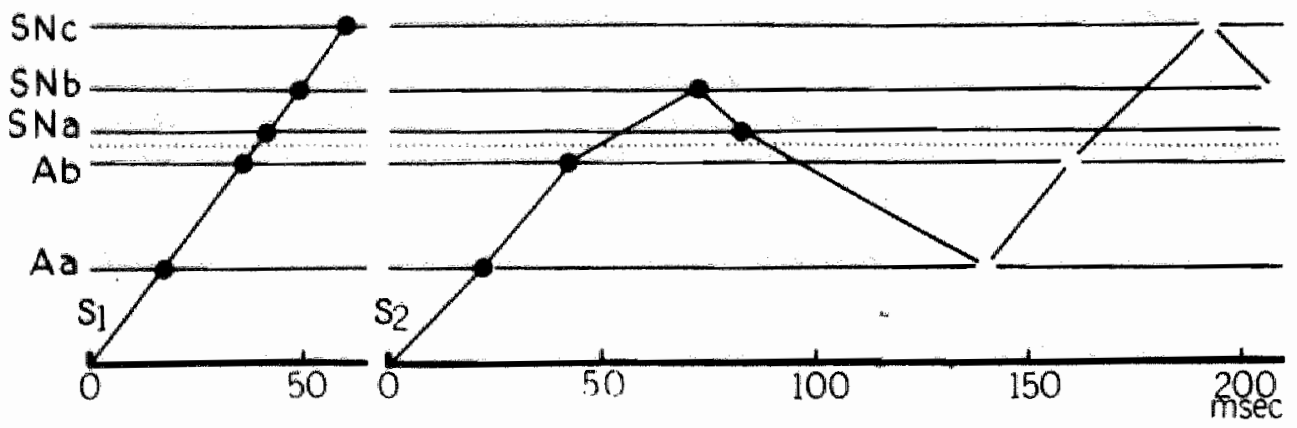

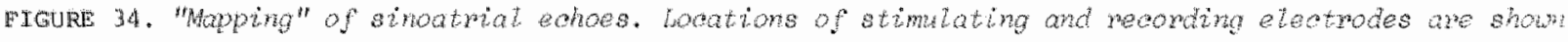

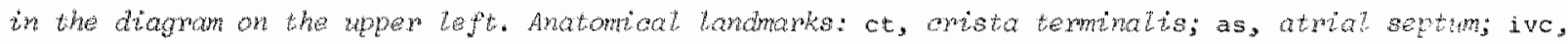

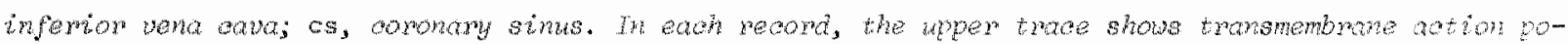

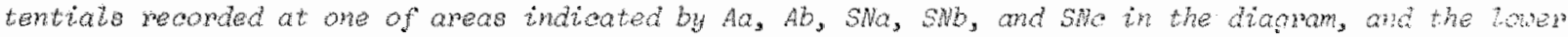

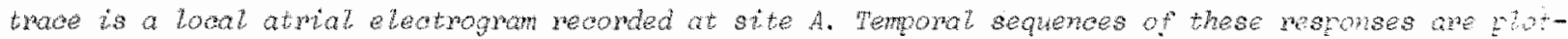

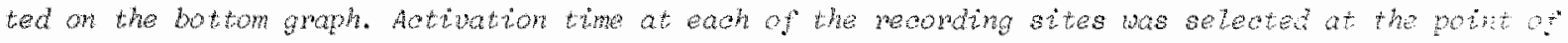

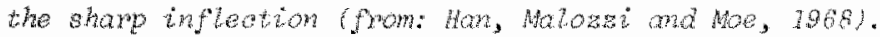


(Aa, Ab, SNa, SNb, and SNc) each of these areas include 2 to 4 puncture sites which provided almost identical temporal patterns. In the ladder diagran at the bottom the sequence of activation of the different fibers is depicted. During the paced basic rhythm the impulse propagates from the point of stimulation to fibers $A a, A b$, SNa, SNb, and SNC in that order; the retrograde sino-atrial conduction time (measured between the moment of stimulation and the response of fiber SNc) was $60 \mathrm{msec}$. During the conduction of the premature beat the order of activation of the sinus node fibers had completely changed. Now fiber sNb is activated first (about $75 \mathrm{msec}$ after $\mathrm{s}_{2}$ ), followed by SNa ( $85 \mathrm{msec}$ after $\mathrm{s}_{2}$ ); the area of fiber SNC is not activated at all by the premature impulse (partial sinoatrial entrance block). The impulse leaves the sinus node somewhere in the area of fiber SNa, and the atrium is reexcited. This echo beat is indicated by open circles in the ladder diagram. Then the impulse invades the sinus node again, namely at the region that not primaxily responded to the premature impulse farea SNc). After having induced yet a second response in fiber SNb, the impulse is extinguished somewhere in the node. Fiber SNa was not reentered by the impulse.

Although, because of the limited number of intranodal impalements, these data cannot be regarded as definitive proof of a circuit within the sinus node, they strongly suggest that, like in the $A-V$ node, also in the S-A node functional. dissociation may occur. However, there is also a major difference whereas in the A-V junction premature stimulation of the atrium commonly resulted in multiple reentrant responses, as a rule only a single echo beat resulted in the sino-atxiw al region. Actually in the sinus node itself only abortive reentry was demonstrated. From the recorded sinus node fibers in Fig. 34, fetber sNb is the only" w, one which showed a double response after the prenature stimulus. The other fiber were activated either during the first or during the second entry of the sinus node, but they could not respond to both impulses. In other words. augtatred circus movement, so well documented in the $A-V$ nodal region, has not been demonstrated in the sinus node.

Experimental results rather point into another direction. Fig. 35 can serve as an example (BONKE, 1968). It shows an atrial electrogram and the transmembrane potential of a sinus node fiber, recorded from the isolated right atrium of the rabbit. During spontaneous beating a single prenature stimulus was introduced in the atrium (arrow). In panel. A the evoked premature beat was followed by yet another, non-stimulated, atrial response. So far this registration resembles very 
much the experiments of HAN, MLOZZI a MoE (1968). In fact panel A of Ifig: 35 is similar to their parel D (compaxe Fig. 34). Accordingly, as an iselated observation this response could be equally explained on the basis of sinoatrial reciprocation.
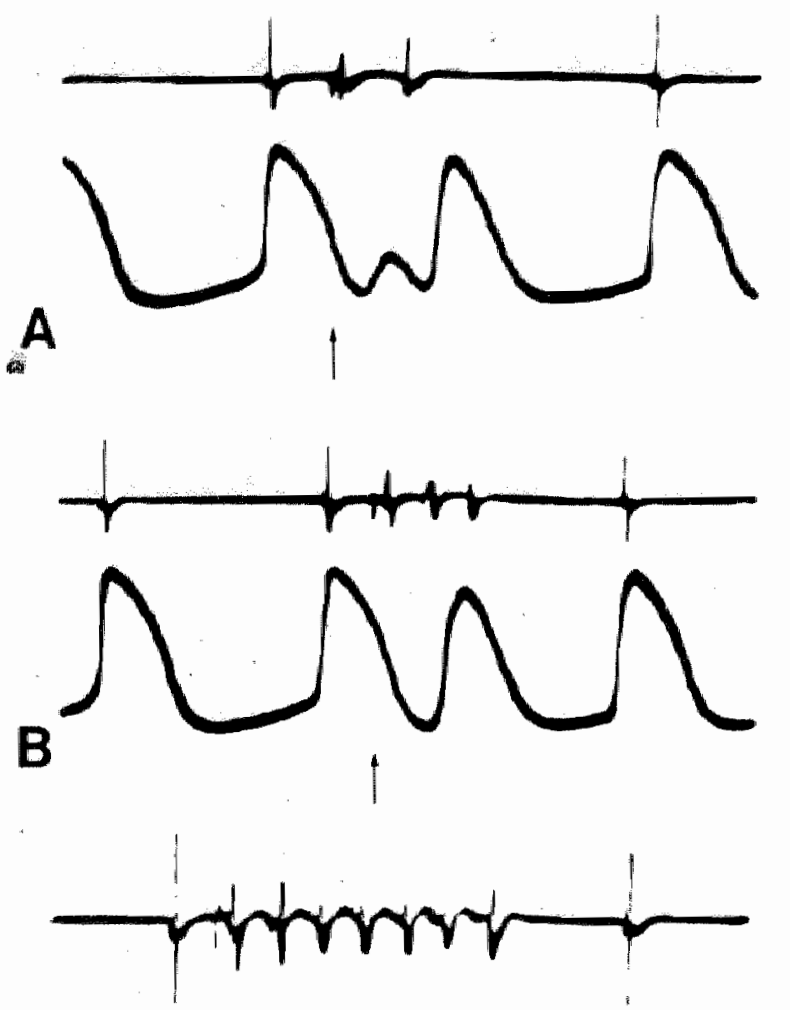

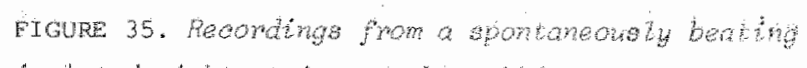

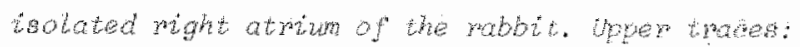

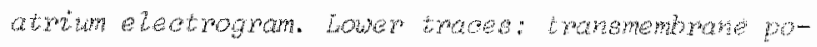
tentiat of one faber the whe wode. The wrow tritrates the moment of premature stimtalion th

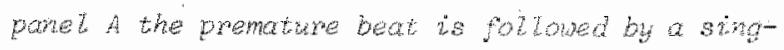
le non-stimulated beat, th parel o by bo antra beats and in pone? $c$ by a whole septes of math atrint diacharges. The resemse of the aimo hore

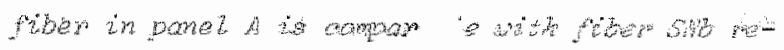

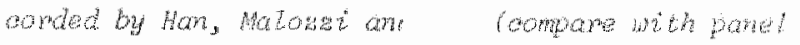

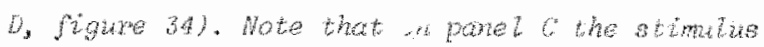

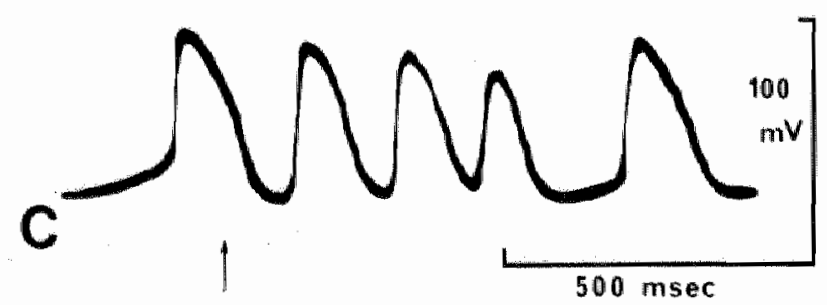

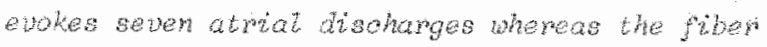

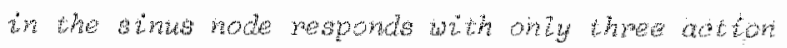
potentials (gom : Bonke, 7968 ).

However, a short time later panels $\mathrm{B}$ and $\mathrm{C}$ were recorded. Now the single premature stimulus is followed by three respectively seven atrial discharges. The sinus node fiber responded with only one respectively three action potentials: This additional observation makes it very unlikely that these short periods af tachycardia are based on sustained circus movement within the sinus node. The beat to beat interval of the atrium was about 70 msec. This is much too short for the sinus node fibers to recover their excitability and therefore they cannot form part of a possible closed circuit. Instead the runs of tachycardia can be bettex explained by circulating excitation in a small part of the atrial myocardium 
close to the simus node. The possibility of such a small reentrant pathway in the atrium is thoroughly discussed in the following chapters of this thesis. The simus node itself then behaves as during rapld pacing of the atria depending on the rate of the tachycardia it shows different degrees of sino-atrial entrance block. On the other hand it cannot be excluded that sustained circus movement may be possible in a "sick" sinus node, but as long as sustained sinus echo rhythms could not be provoked experimentally, this possible mechanism of supraventricular tachycardia should be considered with extreme reserve.

\section{REEERENCES}

Allessie, M.A., Bonke, E.I.M., Schopman, F.J.G.: Circus movement in rabbit atrial muscle as a mechanism of tachycaraia. Circ. Res. 33, 54-62 (1973). Allessie, M.A., Bonke, F.I.M., Schopman, F.J.G.: Circus movement in rabbit atrial muscle as a mechanism of tachycardia. II. The role of nonuntform recovery of excitability in the occurrence of unidirectional block as studied with multiple microelectrodes. Circ. Res. 39, 168-177 (1976).

Allessie, M.A., Bonke, F.I.M., Schopman, F.J.G.: Circus movement in rabbit atrial muscle as a mechanism of tachycardia. IIT. The "leading circle" concept: a new model of cjucus movement in caraiac tissue without the involvement of an anatomical obstacle. Circ. Res. 40, 000-000 (1977, a). Aliessie, M.A., Bonke, F.I.M., Lammers, W.J.E.P.: The effect of cambamylcholine, adrenaline, ouabain, quinidine and verapamil on circus movement tachycardia in isolated segments of rabit atrial myocardium. In: Reentrant Arrhythmias, Mechanisms and Treatment, ed. H.E. Kulbertus (1977 b). Anderson, R.H., Janse, M.J., van Capelle, F.J.I., Billette, J., Becker, A.E., Durrer, D.: A combined morphologic and electrophysiologic investigation of the rabbit atrioventricular node. Circ. Res. 35, $909-922$ (1974). Anderson, R.H., Becker, A.E., Brechenmacher, C., Davies, M.J., Rossi, I.. The human atrioventricular junctional area. A morphological study of the M-V node and bundle. Eur. J. Cardiol. 3, 11-25 (1975).

Anderson, R.H., Becker, A.E., Brechenmacher, C., Davies, M.J., Rossi, L: Ventxicular pre-excitation. A proposed nomenclature for its substrates. Eur. J. Cardiol. 3, 27-36 (1975).

Barker, P.S., Wilson, F.N., Johnston, F.D.: Mechanjsm of auricular paroxysmal tachycardia. Am. Heart J. 26, 435-445 (1943). Billette, J., Janse, M.J., van Capelle, F.J.L., Anderson, R.H., Touboul, P., Durrer, $D$.: Cycle Iength dependent properties of $A-V$ nodal activation in rabbit heart. Am. J. Physiol. 231, 1129-1139 (1976). 
Bonke, F.I.M.: De atrium-extrasystole. Thesis, Hollandia offset, (1968). Bonke, F.I.M., Bouman, L.N., Schopman, F.J.G.: Effect of an early atriaI premature beat on activity of the sino-atwial node and atrial rhythm in the rabbit. Cixc. Res. 29,704-715 (1971).

Childers, R.W., Arnsdorf, M. , de la Fuente, D.J., Gambetta, M., Svenson, R.: sinus nodal echoes. Am. J. Cardio1. 31, 220-231 (1973).

Cranefield, P.F., Klein, H.O. "Hoffman, B.F. : Conduction of the cardiac imoulse. I. Delay, block, and one-way block in depressed Purkinje fibers. Circ. Res. 28, $199-219(1971)$.

Cranefiela, F.F., Hoffman, B.F.: Conduction of the cardiac impulse. II. Sumation and inhibition. Circ. Res. 28, 220-233 (1971).

Downar, E., Janse, M.J., Durrer, D.: The effect of "ischemic" blood on transmembrane potentials of normal porcine ventricular myocardium. Circulation, 55, 00-00 (1977, a). In press.

Downar, E., Janse, M.J., Durrer, D.: The effect of acute coronary artery occlusion on subepicardial transmembrane potentials in the intact porcine heart. (1977, b). In press.

Durrer, D., Roos, J.P.: Epicardial excitation of the ventricles in a patient with Wolff-Parkinson-White syndrome (type B). Circulation, 35, 15 (1967). Durrer, D., Schuilenburg, R.M., wellens, H.J.J.: Pre-excitation revisited. Am. J. Cardiol. 25, 690 (1970).

Durrex, D., Wellens, H.J.J.: The Wolff-parkinson-White synarome anno 1973. Eux. J. Cardiol. 1, 347-367 (1974).

Exichsen, J.E.: On the influence of the coronary circulation on the action of the heart. Lond. Med. Gazette $2,561-564$ (1842).

Gallagher, J.J., Sealy, W.C., Wallace, A.G., Kasell, J.: Correlation between catheter electrophysiologic studies and tindings on mapping of ventricular excitation in the W. P.W. syndrome. In: The conduction system of the heart. Eds. Wellens, Lie, and Janse. Stenfert Kroese, Leiden (1976).

Garrey, W.E.: The nature of fibrillary contraction of the heart. Its relation to tissue mass and form. Am. I. Physioll. 33, 397-414 (1914).

Garrey, W.E.: Auricular fibrillation. Physiol. Rev. 4, 215-250 (1924). Han, J., Malozzi. A.M., Moe, G.K.: Sino-atrial reciprocation in the isolated rabbit heart. Circ. Res. $22,355-362$ (1968).

Harvey, William: Exercitatio anatomica de motu cordis et sanguinis in animalibus. Sumptibus Guilielmo Fitzeri, Francofurti, 1628. Translated from the original Latin by Kenneth J. Frank1in (1957), Blackwe11, oxford. Chapter 4. 
Hayden, W.G., Hurley, E.J., Rytand, D.A.: The mechanism of canine atrial flutter. Circ. Res. 20,496-505 (1967).

Hoffa, M., Luawig, C.: Einige neue versuche über Herzbewegung. Zeitschrift fủr Rat. Med. 9 , 107-144 (1850).

Hoffman, B.F., Cranefield, P.F.: Electrophysiology of the heart. MoGraw-Hill Book Company, Inc., New York (1960), p. 124.

Janse, M.J., van Capelle, F.J.L., Freud, G.E., Durrer, D.: Circus movenent within the $A-V$ node as a basis for supraventricular tachycardia as shown by multiple microelectrode recordings in the isolated rabbit heart. circ. Res. 28 . $403-414(1971)$

Janse, M.J., Downar, E.: The effect of acute ischemia on transmembrane potentials in the intact heart. In: Reentrant Arrhythmias, Mechanisms and Treatment, eaitor: H.E. Kulbertus (1977).

Josephson, M.E., Kastor. J.A.: Paroxysmal supraventricular tachycardia. Is the atrium a necessary link? Circulation, 54, 430-435 (1976).

Kent, A.F.s.: Proceedings Physiological Society, November 12. J. Physiol. 14, $23(1892)$.

Kent, A.F.S.: Observations on the auriculo-ventricular junction of the mammalian heart. Q.J. Exp. Physiol. 2, 193-195 (1913).

Kimura, E., Kato, K., Murao, S., Ajisaka, H., Koyama, S., Omiya, z.: Experimental studies on the mechanism of the auricular flutter. Tohoku J. Exp. Med. 60, $197-207(1954)$.

Lanari, A., Lambertini, A., Ravin, A.: Mechanism of experimental atral futter. Circ. Res. 4, 282-287 (1956).

Lewis, T. et al.: Observations upon filuter and fibrillation. Parts I IX. Heart $I, 127-130,191-346 ; 3,37-58,83-228$ (1918-1921):

Lewis, T.: The mechanism and graphic registration of the heart beat. $3 x d$ Edition, Shaw and Sons, London (1925).

Mayer, A.G.: Rhythmical pulsation in scyphomedusae. Publication no. 47 of the Carnegie Institution of washington (1906).

Mayer, A.G.: Rhythmical pulsation in scyphomedusae. II. Papers from the Marine Biological Laboratory at Tortugas, 115-131, washington (1908).

Mchilitam, J.A., Fibrillar contraction of the heart. J. Physiol. 8, 296-310 (1887). McWilliam, J.A.: Cardiac failure and sudden death. Br. Med. J. 1, 6-8 (1889). Mendez, C., Moe, G.K.: Demonstration of a dual A-V nodal conduction system in the isolated rabbit heart. Circ. Res. $19,378-393$ (1966). 
Mendez, C., Mueliex, W.J., Merideth, J., Moe, G.K.: Interaction of transmembrane potentials in canine purkinje fibers and of Purkinje fiber-muscle junctions. Circ. Res. 24, 361-372 (1969).

Mignone, R.J., Wallace, A.G.: Ventricular echoes: Evidence for dissociation of conduction and re-entry within the $A-V$ node. Circ. Res. 19, 638-649 (1966). Mines, G.R.: On dyramic equilibrium in the heart. J. Physiol. 46, 349-383 (1913). Mines, G.R.: on circulating excitations in heart muscles and their possible relation to tachycardia and fibrillation. Trans R. Soc. of Canada, Section IV, $43-53(1914)$.

Moe, G.K., Preston, J.B., Burlington, H.: Physiologic evidence for a dual A-V transmission system. Circ. Res. 4 . 357-375 (1956).

Moe, G.K., Mendez, C., Han, J.: Aberrant A-V impulse propagation in the dog heart: a study of functional bundle branch block. Circ. Res. 16, 261-286 (1965). Narula, O.S.: Sinus node reentry. A mechanism for supraventricular tachycardia. Circulation 50, $1114-1128$ (1974).

Paulay, K.I., Varghese, P.J., Damato, A.N.: Atxial rhythms in response to an early atrial premature depolarization in man. Am. Heart. J. 85, 323-331 (1973). Puech, P.: The $P$ wave: Correlation of surface and intra-atrial electrograms. In: Complex electrocardiography 2. Editors: A.N. Brest and C. Fisch. F.A. Davies Company, phidadelphia (1974).

Rosenblueth, A., Garcia Ramos, J.: Studies on flutter and fibrillation. II. The influence of artificial obstacles on experimental auricular flutter. Arr. Heart J. 33, 677-684 (1947).

Rytand, D.A.: Review: The circus movement (entrapped circuit wave) hypothesis and atrial flutter. Ann. Intern. Med. 65, 125-159 (1966).

Sasynitu, B.I., Mendez, C.: A mechanism for reentry in canine ventxicular tissue. Circ. Res. 28, 3-15 (1971).

Schnitt; F.A., Erlanger, J.: Directional differences in the conduction of the impulse through heart muscle and their possible relation to extrasystolic and fibrillary contractions. Am. J. Physiol. 87, 326-347 (1928-1929).

Tranum-Jensen, J.: The fine structure of the atrial and atrio-ventricular (A-V) junctional. specialized tissues of the rabbit heart. In: The conduction system of the heart. Eds. Wellens, Lie, and Janse. Stenfert Kroese, Leiden (1976). 
Vulpian, A.: Note sur les effets de la faradisation directe des ventricules du coeur chez le chier. Arch. de physiol. 1, 975-980 (1874).

Wellens, H.J.J., Schuilenburg, R.M. "Durrer, D.: Electrical stimulation of the heart in patients with ventricular tachycardia. Circulation 46, 216-226 (1972). Wellens, H.J.J., Lie, K.I., Durrer, D.: Further observations on ventricular tachycaraia as studied by electrical stimulation of the heart. Chronic recurrent ventricular tachycardia and ventricular tachycardia during acute myocardial infarction. Circulation $49,647-653$ (1974).

Wellens, H.J.J.: Pathophysiology of ventricular tachycardia in mar. Arch. Intern. Med. $135,473-479$ (1975).

Wellens, H.J.J., Durrew, D.: The role of an accessory atxioventricular pathway in recipracal tachycardia. Observations in patients with and without the Wolff-Parkinson-White syndrome. Circulation 52, 58-72 (1975).

west, T.C., Cox, A.R.: Single fiber recording during the production and control of flutter in the isolated atrium of the rabbit. J. Pharmacol. Exp. Ther. $130,303-310(1960)$.

West, T.C., Landa, J.F.: Minimal mass required for induction of a sustaned arrhythmia in isolated atrial segments. Am. J. Physiol. 202, 232-236 (1962). Wit, A.L., Goldreyer, B.N., Damato, A.N.: An in vitro model of paroxysmal supraventricular tachycardia. Cixculation 43 , 862-875 (1971).

Wi.t, A.L., Hoffman, B.F., Cranefield, P.F.: Slow conduction and reentry in the ventricular conducting system. I. Return extrasystole in canine purkinje fibers. Circ. Res. 30, 1-10 (1972, a).

Wit, M.L., Cranefield, P.F., Hoffman, B.F.: Slow conduction and reentry in the ventricular conducting system. II. Single and sustained circus movement in networks of canine and bovine Purkinje fibers. Circ. Res. 30, 11-22 (1972, b). Wu, D., Amat-y-Leon, F., Denes, P., Dhingra, R.C., Pietras, R.J., Rosen, K.M.: Demonstration of sustained sinus and atrial reentry as a mechanism of paroxysmal supraventricular tachycardia. Circulation 51, 234-243 (1975). 


\section{Chapter 3}

\section{Circus Movement in Rabbit Atrial Muscle as a Mechanism of Tachycardia}

By Maurits A. Allessie, Felix I. M. Bonke, and Francien J. G. Schopman 


\title{
Circus Movement in Rabbit Atrial Muscle as a Mechanism of Tachycardia
}

\author{
By Maurits A. Allessie, Felix I. M. Bonke, and Francien J. G. Schopman
}

\begin{abstract}
ABSTRACI
The isolated left atrium of the rabbit, which showed no spontaneous activity, was electrically driven for 20 beats with a cycle length of $500 \mathrm{msec}$. Tachycardia could be repeatedly initiated by the application of a single adequately timed stimulus shortly after the refractory period of the last basic beat. After the termination of the tachycardia, either spontaneously or artificially by a properly timed stimulus, this procedure was repeated. The number of beats of these tachycardias varied from just one (coupled extrasystole) to many hundreds. Surface electrograms were recorded at about 300 different sites. From the moments of activation of these sites, the spread of activation during regular driving and during the premature beat and the subsequent tachycardia could be determined. In contrast to the radinl spread of the activation during basic rhythm, the impulse of the premature beat was propagated in a circular pathway. "This circus movement was maintained during tachycardia. These results show that even in a small area of atral muscle containing no amatomical obstacle the impulse can be eritrapped in circus movement. This circus movement was the underlying mechanism of the arrhythmia.
\end{abstract}

KEY WORDS

unidirectional block surface electrogram initiation and termination of tachycardia atrial premature beats reentry
From the many investigations that have been done to explain the mechanism underlying flutter and fibrillation of the heart, two alternative hypotheses have emerged: that of ectopic impulse formation and that of circus movement.

The possibility of a circus movement of the cardiac impulse was first mentioned by MoWilliam in 1887 (1). In 1908 circus movement was demonstrated by Mayer (2) in rings cut from the bells of medusae. Mines $(3,4)$ and Garrey (5) described experiments, conducted at about the same time but independently of each other, on the production of circulating excitation in rings cut from cardiac tissue. Since then circus movement has been proposed frequently as the basic mechanism underlying various cardiac arrhythmias (6).

In contrast to this popularity however, it has not always been easy to provide direct evidence for this hypothesis. A definite proof of a circus movement can be obtained by following the course of the activation process from point to point during at least one interval of the arrhythmia in question. Indeed this procedure has been tried by several

From the Department of Physiology, University of Amsterdam, Jan Swammerdam Instituut, Ist Const. Huygensstraat 20, Amsterdam, the Netherlands.

This work was supported by Grant 73-054 from the Nederlandse Hartstichting.

Received February 13, 1973. Accepted for publication April 27, 1973. investigators $(7-11)$. A main difficulty of this approach however is the limitation of the number of electrograms that can be recorded simultaneously.

In an attempt to avoid this limitation, we used a preparation in which periods of tachycardia could be initiated repeatedly by the application of a single stimulus shortly after the refractory period. Electrograms were recorded sequentially in banks of ten and time aligned using a common reference lead. The moments of activation of more than 300 sites could be measured in this way. The maps of the spread of activation during regular driving of the preparation and during tachycardia led to the conclusion that a circus movement of the excitatory process in a relatively small area of atrial muscle was the basis for the tachycardias in our experiments.

\section{Methods}

\section{PIREPARATION}

Young adult New Zealand rabbits $(2-3 \mathrm{~kg})$ of both sexes were anesthetized with sodium pentobarbital ( 20 $\mathrm{mg} / \mathrm{kg}$, iv). Duringi artificial respiration, anesthesia was maintained with ether. All rabbits received 1,500 IU of heparin. The heart was rapidly removed and kept in oxygenated perfusion solution at $37^{\circ} \mathrm{C}$. The left atrium was isolated, and the preparation, including the roof of the left atrial appendage and an adjacent part of the body of the left atrium, was fixed in a tissue bath with the endocardial side up. Care was taken to completely remove the sinoatrial node, the atrioventricular node, and the interatrial septum containing the part of the left 
atrium with the entrances of the pulnonary veins. The preparation thus obtained measured about $15 \times 20 \mathrm{~mm}$ and did not show spontaneous activity.

The perfusion fluid had the following millimolar composition: $\mathrm{NaCl} 130, \mathrm{KCl} 5.6, \mathrm{CaCl}_{2}, 2.2, \mathrm{MgCl}_{2} 0.6$, $\mathrm{NaHCO}_{3} 24.2, \mathrm{NaH}_{2} \mathrm{PO}_{4} 1.2$, glucose 11 , and sucrose 13. The fluid was saturated with a mixture of $95 \% \mathrm{O}_{2}-5 \%$ $\mathrm{CO}_{2}$, entered the tissue bath at the bottom, and was sucked off at the surface at a rate of $100 \mathrm{ml} / \mathrm{min}$. The $\mathrm{pH}$ was kept at $7.35 \pm 0.05$ and the temperature at $37 \pm 0.1^{\circ} \mathrm{C}$.

\section{STIIMULATION}

A bipolar electrode consisting of two silver wires (diameter $0.2 \mathrm{~mm}$, interelectrode distance $0.5 \mathrm{~mm}$ ) was placed on the endocardial surface and used as the stimulating electrode. The preparation was paced at a regular rate (interval $500 \mathrm{msec}$ ) by constant-voltage shocks (duration $1 \mathrm{msec}$, intensity twice threshold value at most) from the stimulus isolation unit of a Grass S4 stimulator. After every twentieth beat this basic rhythm was interrupted by a test stimulus (duration $1 \mathrm{msec}$, intensity less than fourfold diastolic threshold) delivered from another Grass S4 stimulator via the same stimulating electrode. The interval between the basic and the test stimulus could be adjusted with an aceuracy of $0.5 \mathrm{msec}$ by at delay circuit. Before the basic rhythm was restarted, the preparation was not stimulated for about 2 seconds (Fig. 1).

\section{RECORDING}

To study the activation pattem during the early premature beat and the beats of the subsequent tachycardia, it is necessary to record the electrical activity at as many sites as possible. However, it was impossible to accommodate for example 200 surface electrodes on the preparation and to store their registrations on a recorder. For that reasom, we developed the following registration method. We employed an electrode holder containing ten silver terminals mounted in a straight line. Each terminal had a diameter of $0.2 \mathrm{~mm}$, and the interterminal distance was $1 \mathrm{~mm}$. With this electrode array, ten unipolar surface electrograms could be recorded simultaneously, using an $\mathrm{Ag}-\mathrm{AgCl}$ strip placed in the bath fluid as the indifferent electrode. The recording electrode was mounted on a solid, accurate micromanipulator (Meijer and Schreurs, to be published), which enabled us to move this electrode quickly to a new position.

For the induction of tachycardia two variables appeared to be very important, namely the position of the stimulating electrode and the moment the test stimulus was given (see Results). When we had found the right combination, registration was started. After each period of tachycardia, the multiple recording electrode was moved to another site. Thus we were able to record the electrical activity of at least 300 sites on the preparation during the onset of tachycardia. Of course this method of registration is only reliable when the spread of activation is the same during the subsequent tachycardias. Therefore, we used a control electrogram from a fixed bipolar electrode to check whether the activation times (latency between the test stimulus and the intrinsic deflection of the electrogram of the premature beat or the beats during tachycardia) and the shapes of the complexes were the same during the different episodes of tachycardia.

\section{DATA PROCESSING}

After amplification to the level of approximately $1 \mathrm{v}$ all electrograms were stored on magnetic tape (Ampex FR 1300, tape speed 15 inches/sec). For each recording the position of the micromanipulator, indicating the relative position of the exploring electrode, was read and recorded also. For time measurements the tapes were played back at a speed of 1.875 inches/sec, and the complexes were printed out on a 14-chamnel Elema inkwriter (type EMT 160) running at a speed of $120 \mathrm{~mm} / \mathrm{sec}$. This procedure resulted in a time resolution of better than 1 msec. The fast part of the intrinsic deflection of the complexes was taken as the moment of activation at the relevant site. At the end of the experiment the preparation was photographed with the exploring electrode at different positions. From these photographs and the known positions of the micromanipulator during recording, the actual recording sites were defined, and maps were drawn in which the activation times of each site during the last basic beat, the early premature beat, and the beats during tachycardia were noted.

\section{Results \\ INDUCTION OF TACHYCARDIA}

It has been known for a long time that a single induction shock applied directly after the end of the refractory period can produce flutter or fibrillation of the heart $(4,12)$. Also generally accepted is the view that periods of tachycardia and fibrillation, as observed clinically in man, almost without exception are preceded by the occurrence of a premature beat (13). Recently, Bonke et al. (14) have shown that, even in a small piece of apparently homogeneous atrial muscle, the induction of an early premature beat can evoke a series of rapid atrial discharges. This phenomenon is illustrated in Figure 1. If properly timed, no current of high

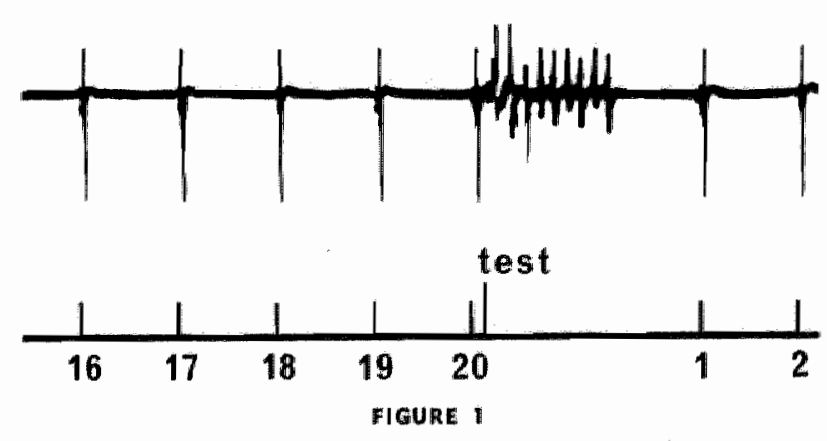

Induction of a period of tachycardia by the application of a tesit stimulus shomly after the refractory period. Top: Surface electrogram. Bottom: Schematic representation of the stimulation patern. The tntervals between the basic stimuli are 500 misec. 

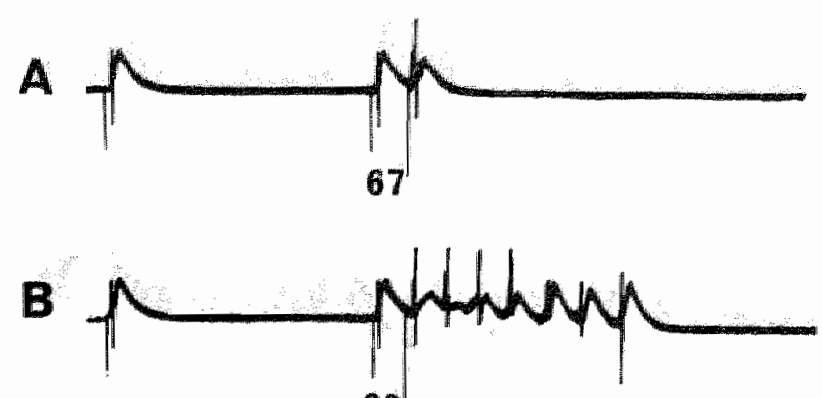

66
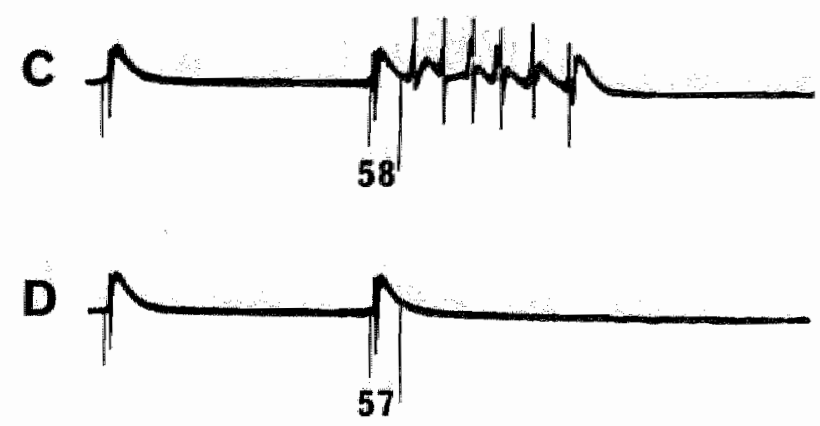

FICURE 2

Effects of a premature stimulus applied at wartous moments in the cardiac cycle. The numbers tndicate the tnterval (msec) between the last basic stimulus and the premature stimulus. See text for discusston. intensity or long duration is needed, nor is it necessary to use electrodes of large size.

Further investigation on this subject revealed that it did not matter whether the current was applied by a bipolar or a unipolar electrode or, when unipolar stimulation was used, whether the punctate electrode was the cathode or the anode. Although with anodal stimulation more current had to be applied than with cathodal or bipolar stimulation, in all cases periods of tachycardia could be evoked. This finding suggests that not the applied current itself but merely the occurrence of a premature propagated activation was responsible for this phenomenon.

Figure 2 shows some representative tracings, illustrating the possible effects of a test stimulus applied at various moments of the cardiac cycle. When the test stimulus was given $67 \mathrm{msec}$ or more after the basic stimulus, a single extrasystole resulted (A). Shortening the interval resulted in runs of tachycardia ( $B$ and $C$ ). When the test stimulus was applied with an interval of $57 \mathrm{msec}$ or less, no conducted response was recorded at all (D). Thus, the period in the atrial cycle in which a premature beat resulted in a series of rapid atrial

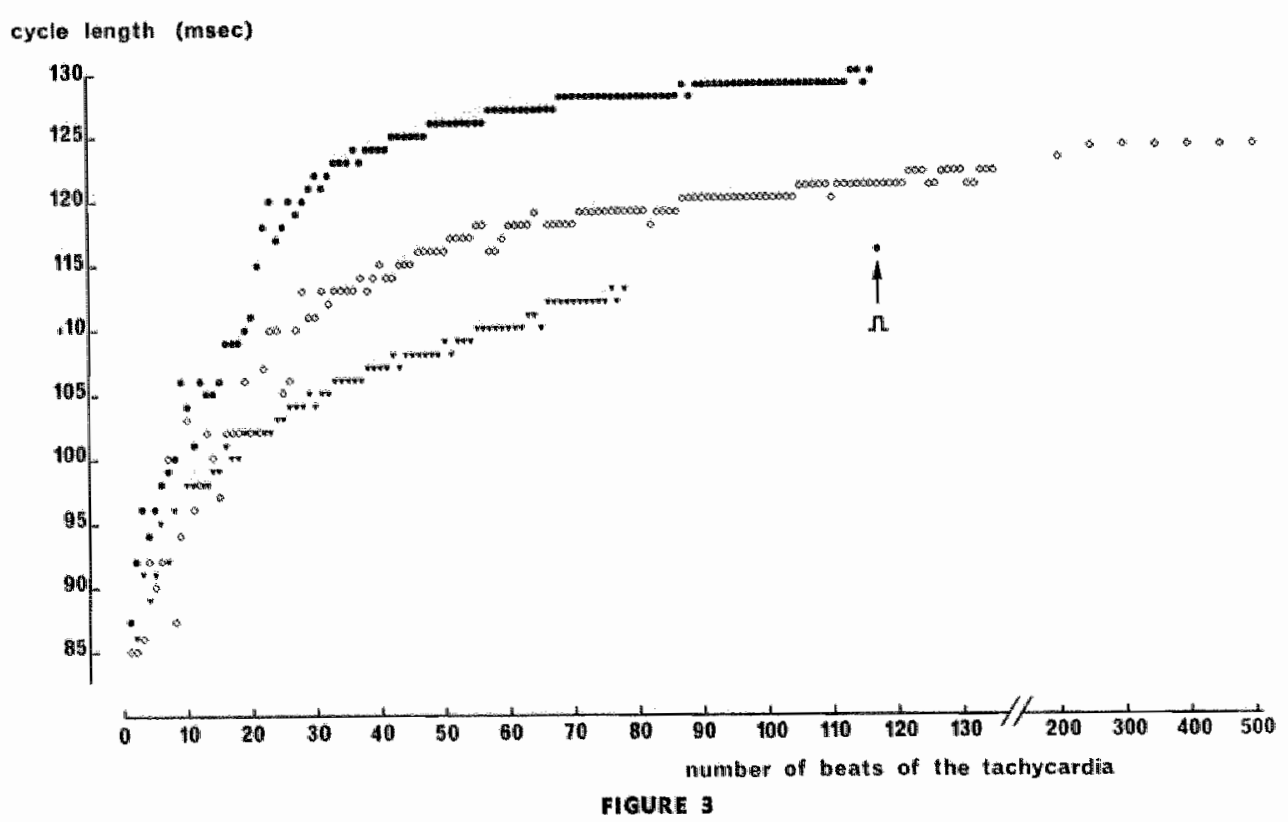

Cycle length during tachycardia plotted sequentially for three different experiments. At the beginning of the tachycardia cycle length gradually increased. Thereafter, the rate became constant. The tachycardia indicated by the triangles stopped abruptly after 78 beats; the tachycardia represented by the solid. circles was terninated by a stimulus which resulted in a last shortened interval (arrow). The third tachycardia (open symbols) lasted for many minutes. 
discharges was quite short. In this case it amounted to $9 \mathrm{msec}$, but often an even shorter period down to 2 msec was found. Not only was the moment at which the premature beat was elicited very critical, but also the place where the extrasystole was initiated seemed to be of even greater importance. In fact, only a few places could be found where a properly timed stimulus caused tachycardia. The most favorable place was the area where the appendage passes into the body of the left atrium.

\section{RATE AND RHYTHM OF THE TACHYCARDIA}

The cycle length during tachycardia showed a typical and consistent change during the development of tachycardia. In Figure 3 the cycle lengths of three longer periods of tachycardia, as obtained from three different preparations, are plotted sequentially. In the initial phase of tachycardia a gradual increase in cycle length was always observed. When tachycardia progressed, the cycle length became more and more regular until after about 100 beats a constant rate was reached. The cycle length varied from preparation to preparation between 100 and $150 \mathrm{msec}$ when the tachycardia became steady. The end of tachycardia was abrupt: either it stopped spontaneously (triangles) or it was terminated by a stimulus (solid circles).

\section{PATHWAY OF THE EXCITATION WAVE DURING TACHYCARDIA}

Figure 4 shows some results of an experiment in which the electrical activity of more than 300 sites was recorded during regular driving of the atrium and during the initiation of tachycardia. In this figure only ten electrographic tracings $(A-K)$ are shown. The preparation was driven at a regular rate (interval $500 \mathrm{msec}$ ) for 20 beats. Then a premature beat was elicited by applying a test stimulus 81 msec after the last basic stimulus. This early premature beat repeatedly resulted in a series of rapid repetitive atrial discharges.

The first electrogram of each recording represents the last regularly driven beat. The excitatory process of this basic beat showed a concentric spread from the site of stimulation; the sites in the neighborhood of the stimulating electrode $(A, B, J$, and $K$ ) were activated before the more distant sites.

The premature impulse was propagated in a very different way. Although the conduction velocity was reduced strikingly, the sequence of activation of sites A-F remained unaltered and the configuration of the complexes showed only minor changes. On the other hand, at site $K$ only a slight deflection was recorded (see arrow), and antegrade conduction failed completely toward sites $J, H$, and $G$. These sites were activated after the excitation of sites $\mathrm{E}$ and $F$, and their sequence of activation was reversed completely. This finding indicates that the impulse of the premature beat was blocked in the neighborhood of site $\mathrm{K}$ and that the blocked area was invaded in a retrograde way.

The change of the activation pattern was reflected also by the explicit changes in the configuration of the electrograms recorded from sites $\mathrm{G}, \mathrm{H}, \mathrm{J}$, and $\mathrm{K}$. Thus, during the propagation
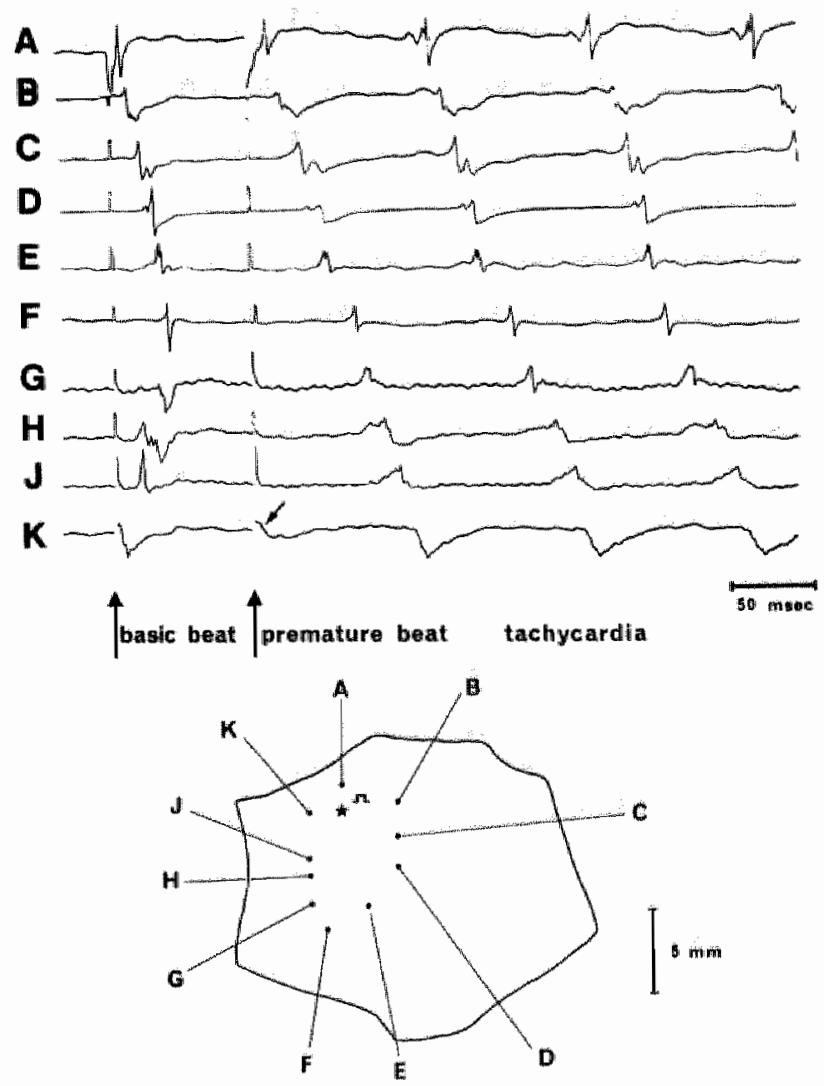

FIGURE 4

Initiation of tachycardia by a premature beat. Surface electrograms recorded at ten sites on the left atriwm $(\mathrm{A}-\mathrm{K})$. The atrium was driten regularly wh a basic interval of 500 msec. The firstarrow indicates the last basic stimulus, and the second arrow indicates the premature stimulus (interod 81 msec). The sketch at the bottom shows the sites at which the electrograms were recorded; the site of stimulation is represented by the astertsk. Note that antegrade conduction. of the premature impulse falled in the direction of sites $G^{-} K$. This area was activated from site $F$ in a retrograde fashion. Sites $A, B, C$, etc. were rexcited from site $K$. This pattern persisted during the ensuing tachycardia. See text for further discussion. 
of the impulse of the premature beat, the radial spread present during the basic rhythm was converted into a circus movement along the route $A$ to $B$ to $C$. . to $\mathbb{K}$. As a result, the activation wave returned to the point of its origin and got the opportunity to cause a reentrant beat.

The occurrence of reentry depends on both the stimulating efficacy of the returning excitation wave and the extent to which the place where reentry might occur has restored its excitability. Since the electrogram of the first beat of the tachycardia recorded from site $A$ followed immediately the activation of sites $\mathbb{J}$ and $\mathrm{K}$, obviously the restoration of the excitability of site $A$ was sufficient to permit reexcitation by the returning activation wave. During the subsequent tachycardia, the sequence of activation established during the premature beat remained unaltered. A more complete reproduction of this experiment is shown in Figure 5 , in which the time measurements of all sites from which electrograms were recorded are mapped. The isochronal lines are related to the moment of the basic stimulus (A) and the test stimulus (B-D). During the basic rhythm, the activation wave propagated radially with a conduction velocity varying from 20 to $50 \mathrm{~cm} / \mathrm{sec}$. This concentric propagation was completely lost with the conduction of the premature beat (B). Great local differences in conduction were then revealed. Conduction was best maintained toward the atrial appendage, although even there the conduction velocity was less than half as fast as it was during the basic rhythm. In the direction of the body of the atrium, the impulse was conducted only for a short distance before it died out completely. From the atrial appendage, the impulse was propagated slowly, invading the blocked area in the flank. This area was now ready to propagate the impulse, and after about $100 \mathrm{msec}$ the impulse reached its starting point again.

The impulse, thus entrapped in a circuitous route, circulated for many revolutions. The subsequent two revolutions are shown in Figure $5 \mathrm{C}$ and $\mathrm{D}$. Thus, in a small piece of atrial muscle, the occurrence of an early premature activation may entrap the excitation process in a vortexlike movement, giving rise to a period of tachycardia. No anatomical obstacle is needed to create this situation.

In a later phase of the experiment presented in Figure 5, tachycardia repeatedly stopped after the first extra beat, resulting in a "coupled extrasystole." As shown in Figure 6, the occurrence of coupled

extrasystolles was also due to a circus movement of the cardiac impulse. But now the activation front was blocked just before it should have started its third round trip. The course of the activation process during tachycardia can also be more complicated, as illustrated in Figure 7 . In this experiment the spread of activation during regular driving of the atrium was radial again (A). A premature beat was elicited $60 \mathrm{msec}$ after the last basic stimulus. Figure 7B shows the spread of this early impulse. The conduction of the premature impulse was blocked to all sides except for a very narrow pathway leading to the appendage. From this narrow outlet the impulse expanded and turned around its point of origin. Two separate activation waves developed in this way, the wave on each side traveling halfway around the stimulation site. These two activation waves collided $75 \mathrm{msec}$ after the

A

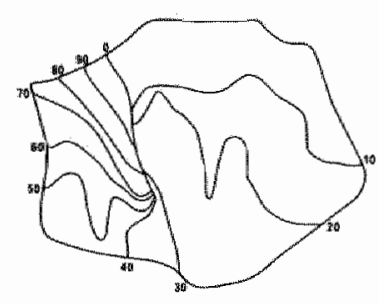

C

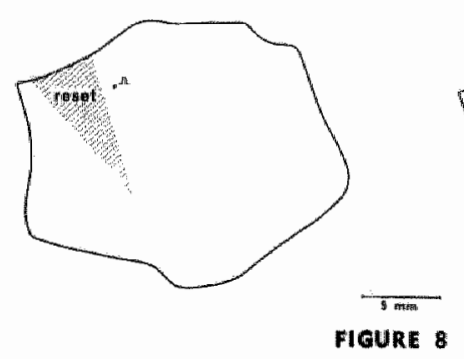

Schematic representation of the effects of premature stimwhicplied during tachycardia. A shows the spread of activation during tachycardia. The mament the activation wave passed the stimulating electrode was taken as zero, and isochronal lines were constructed referring to this moment. In $\mathrm{B}, \mathrm{C}$, and $\mathrm{D}$ the various effects are indicated in relation to the place where the crest of the circus mavement was found on the moment the stimulus was given (site of stimwhation is indicated by a dot). A stimulus had no effect, when the crest of the cincus movement was somewwere in the hatched area, as indicated in $D$. When a stimulus was applied on the moment the crest of the circus movement was somewhere in the white part of $D$, the circus movement was either stopped $(B)$ or reset $(C)$. 
application of the test stimulus. However, before they extinguished each other, the left wave had found an entrance in the area where antegrade conduction of the premature impulse failed, and reentry occurred (C). The impulse then once more split up in two separate waves.

However, now the left wave was blocked, apparently because the impulse traveled too fast in a circuit that was too small for every part of the route to restore its excitability. If, as in the previously described experiment (Fig. 6), this wave had been the only circulating activation wave, tachycardia would have stopped at this moment and a coupled extrasystole would have resulted. However, in this case tachycardia lasted for more than 30 beats because of the presence of the second circulating wave. After one circus movement had stopped, the other went on undisturbed and maintained the tachycardia (Fig. $7 \mathrm{C}$ and D).

\section{TERMINATION OF TACHYCARDIA}

Experimentally induced tachycardias often stopped spontaneously soon after they started. When spontaneous recovery did not occur, the tachycardias could always be terminated by the application of a properly timed stimulus. The timing of this stimulus had to be very accurate, as is demonstrated in Figure 8. In Figure $8 \mathrm{~A}$ the circus movement of the impulse during tachycardia is shown; the activation times refer to the moment the activation wave passed the stimulating electrode. Revolution time amounted to $100 \mathrm{msec}$. The circus movement was interrupted when a stimulus was applied between 60 and $75 \mathrm{msec}$ after the activation wave passed the area of the stimulating electrode (Fig. 8B). Stimuli given earlier found the tissue under the stimulating electrode still refractory and produced no effect at all (Fig. 8D). When the stimulus was given between 75 and $100 \mathrm{msec}$ after the activation wave excited the stimulation site, a slight shortening of the interval was seen in the vicinity of the stimulating electrode and tachycardia was "reset" (Fig. 8C). A more marked shortening of the last interval was recorded when a stimulus was successful in interrupting tachycardia (Fig. 3, solid circles). This observation agrees to a large extent with the results of Janse et al. (11), who studied the effects of atrial premature beats applied during supraventricular tachycardia based on a circulating mechanism within the atrioventricular node.

\section{Discussion}

The induction of a tachycardia by the application of a single adequately timed stimulus did not depend on how current was applied, since bipolar as well as cathodal and anodal unipolar stimulation resulted in the same activation pattern. This finding suggests that a premature activation per se was responsible for the onset of tachycardia. On the other hand, it is conceivable that the pressure exerted by the stimulating electrode caused an area of reduced conductivity. However, this effect is not likely, since complexes with a sharp intrinsic deflection were recorded when the stimulating electrode was used as a recording electrode during tachycardia.

To explain the mechanism of supraventricular tachycardia, two alternative hypotheses have been proposed. In 1920, Lewis et al. (7) stated that atrial flutter was caused by a circus movement of the activation wave around the orifices of the superior or inferior caval veins or both and thus involved a large part of the atria. Other investigators $(10,11)$ drew attention to the possibility of a reciprocating rhythm in the atrioventricular junctional area based on a functional longitudinal dissociation. In cases of supraventricular tachycardia associated with a Wolff-Parkinson-White syndrome, it was shown that a circulating excitation between auricles and ventricles could be the underlying mechanism (15).

In other cases, however, the rapid repetitive activation waves seemed to originate somewhere in a small area of atrial muscle $e_{n}$ and therefore a rapidly firing ectopic focus $(16,17)$ was assumed to be the most probable explanation, since it seemed unlikely that reentry could occur in such a small area of rapidly conducting tissue. Our results, however, show that it is possible for the activation process to be entrapped in a circuitous route even in a small segment of atrial muscle which does not contain any anatomical obstacle. The activation pattem during tachycardia looks like a wortex as is shown in Figures 5-7. The fibers in the center of the vortex are not excited, whereas during basic rhythm these fibers are activated normally. Furthermore, the activation wave propagates faster in the periphery than it does near this center. How is it possible that the fibers in the center of this vortex, consisting of excitable tissue, are not excited? A possible explanation is that the membrane potential of these fibers is held above threshold by the electrotonic influences of the depolarization front which continuously turns around this area. In this 


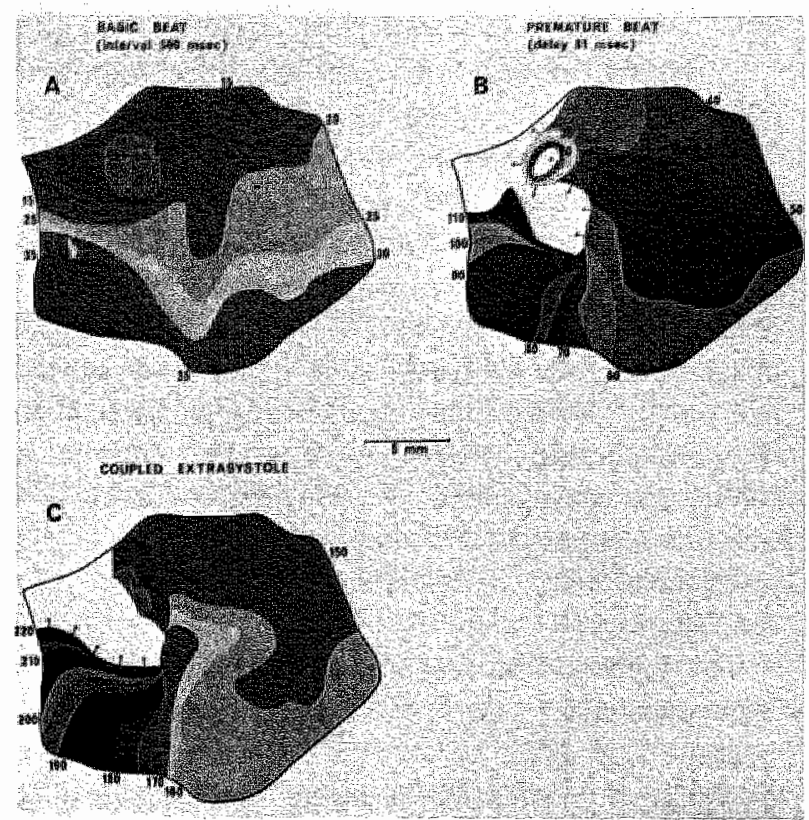

FIGURE 6

Maps of the spread of activation when the premature beat was followed by fust one atrial discharge (coupled extrasystole) in the same experiment thustrated in Figure 5. The activation wave was blocked on ts second round trip. See text for futher discusstion.
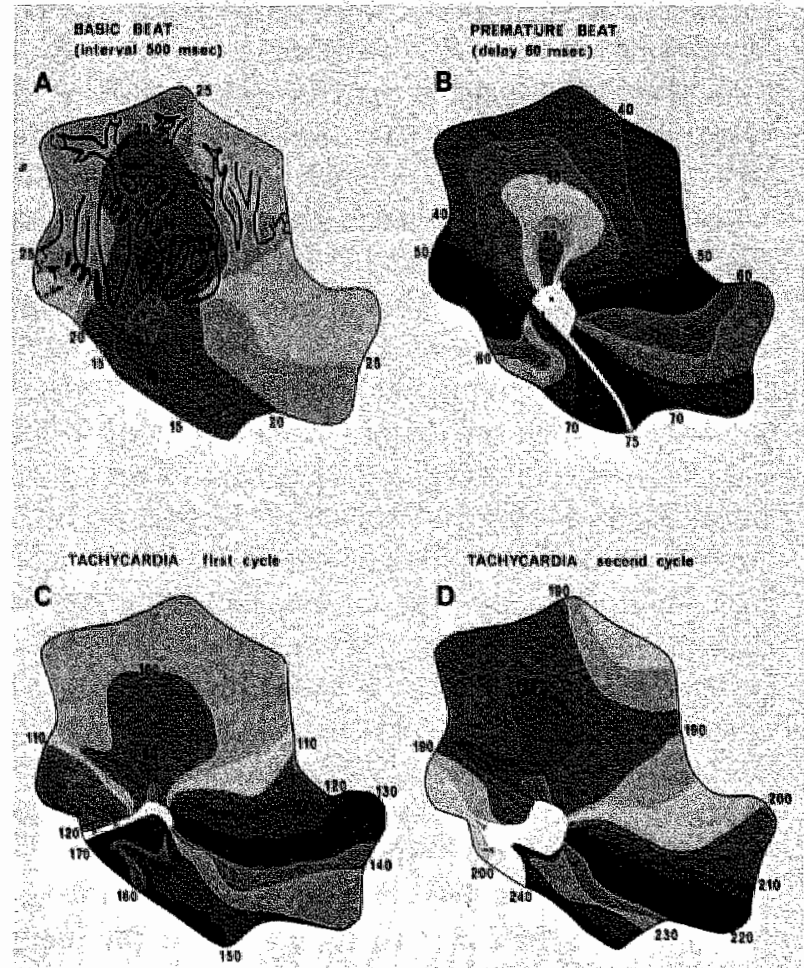

FIIGURE ?

Maph of spread of activation during basic rhythm (A), the premature beat $(\mathrm{B})$, and the subsequent two beats of the tachyoardia (C and $\mathrm{D})$. In this experiment the premature

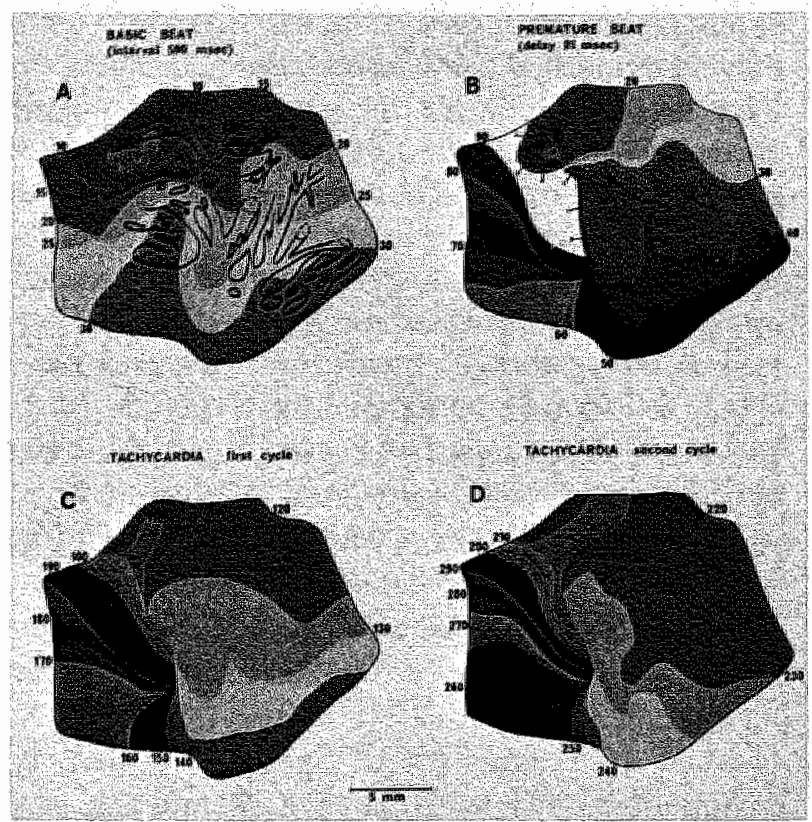

FIGURE 5

Maps of tha spread of activation, composed of the actionthon times of 300 sites, during basic rhythm (A), the premattre beat (B), and the subsectient wo beals of the tachycardia $(\mathrm{C}$ and $\mathrm{DH}$. The site of stimulation is indicated by a black dow in $A$ and $B$. A schematic drawing of the preparation (see Mathods) is stuperimposed in As showing trabecula running from the body of the left atritum (lower left) unto the auricile (upper right). The parts of the preparation that were acturated at about the same moment are indicated by different colotis. The actiluation times are given at the site where the isochronal lines cross the circumference of the map. In athese times concern the interval between the basic stimulus and the intrinsic deflection of the electrowam complex that was recorded, whereas in $B, C$, and $D$ the activation timus are related to the mowent the test stimuthos was aprahed. Dowble bats indicate conduction block. See lex for funther distusion.

way the center functionally is inexcitable, and the activation wave will travel around this functional obstacle. The premature activation created the prerequisite conditions for the onset of this vortex movement, namely, (1) the early premature activation was conducted only in one direction and blocked in another (unidirectional block), and (2) the impulse traveled slowly enough on its circuitous route to enable each site of the route to restore its excitability before the impulse reached it again. The unidirectional block may be caused by asynchronism in recovery of excitability in the fibers surrounding the stimulating electrode. Since during

activation split up into two separate activation woves tuming around the point of origin (B). During tachycardia one wave was blacked, but the other continued to circulate $(C$ and $D$ ). A schematic drawing of the preparation is superimposed in $A$, showing trabecula ruming from the body of the left atrium (bottom) into the auricle (top). 
basic rhythm the fibers of the white area (Fig. 5) were excited simultaneously with those of other areas, this dispersion in excitability has to be explained by a slower recovery of excitability of the fibers in the white area. The impulse of the early premature beat then may be propagated only in the direction of the fibers with the quickest recovery of excitability, while in the other directions the impulse is either not conducted at all or is conducted with so much decrement (18) that it dies out. This dispersion in excitability at the moment the premature activation wave is elicited is apparently only very slight, as is indicated by the fact that the period in the cardiac cycle in which a stimulus provoked a unidirectional block was very short, often no more than $5 \mathrm{msec}$. The fact that the most likely site for a stimulus to provoke tachycardia was near the border between the body of the left atrium and the appendage, raises the question of whether differences in refractory period between atrium and appendage exist. Further investigations are necessary to resolve this problem. The rnarked decrease in the conduction velocity of the impulse during the premature activation compared with that during the basic rhythm might in part be caused by the fact that in some parts of the vortex the activation wave travels in a less favorable direction. Furthermore, conduction velocity is reduced as a consequence of the sudden shortening of the interval from 500 msec to about $70-100 \mathrm{msec}$. Yamagishi and Sano (19) reported a reduction in atrial conduction velocity by $45 \%$ when they shortened the driving interval from 330 to $100 \mathrm{msec}$. Viersma (20) showed that after such a sudden interval change conduction velocity gradually decreased until only after a large number of beats a steady state was reached. This last-mentioned property of atrial muscle might explain the observation that during tachycardia the cycle length, which is determined by the revolution time of the circus movement, gradually increases and becomes regular after 100-300 beats (Fig. 3).

A circus movement will stop when the crest of the activation wave is unable to excite the tissue in the pathway ahead. This event may occur when the stimulating efficacy of the activation front is diminished or when in any part of the circuit excitability is not sufficiently restored at the time when the circulating activation wave reaches the area. The speed of restoration of excitability depends partly on the length of the preceding interval (21). The change of the conduction pattern from a radial type during basic rhythm to a circus movement during the premature beat results in local differences in cycle length between the activation of the last basic beat and the premature beat. At those sites where antegrade conduction of the premature impulse is possible, a relatively small interval is recorded, but, at those sites where antegrade conduction fails and the impulse has to travel in a roundabout way, a much greater interval is present.

Because of these differences in preceding cycle length the premature activation wave itself induces differences in the speed of restoration of excitability. The fibers activated later on will restore their excitability more slowly, and therefore on its second round trip the activation wave will encounter tissue in a progressively less-advanced state of recovery. Consequently, during its second round trip-the first cycle of the tachycardia-the impulse seems to have an increasing chance of dying out (Figs. 6C and $7 \mathrm{C}$ ). The foregoing is in accordance with our observations that the conduction velocity during the second round trip decreases progressively and that a premature beat is more frequently followed by a coupled extrasystole than by a longer-lasting period of tachycardia. Furthermore, the circus movement could be stopped by the application of a properly timed stimulus, as indicated in Figure 8 . When a stimulus is given at the moment the excitability of the tissue under the stimulating electrode is just restored, the impulse might be conducted only in the direction towards the circulating activation front and then this circus movement will be stopped. When the stimulus is given somewhat later, the impulse might be conducted to all sides, resulting in the interruption of the existing circus movement and the initiation of a new activation wave which can travel around in the same circuit, starting a new tachycardia (Fig. $8 \mathrm{C}$ ).

Finally, we want to stress that the ability to induce tachycardia in an excised preparation like the one described in this paper does not prove that a similar mechanism actually exists in the intact heart. It might be that the functional differences that cause one-way conduction in the isolated preparation are not present, or are present to a lesser extent, in the intact normal atrium. Furthermore, it should be mentioned that, although our results strongly point to a circus movement as the mechanism of tachycardia, the possibility that Mines (4) warned against has not been ruled out completely: "The chief error to be guarded against is that of mistaking a series of automatic beats originating in one point and travelling round it in 
one direction only, owing to a complete block close to the point of its origin." However, a main argument against such a rapid automatic focus, which would mimic the circus movement in our experiments, is the observation that, despite considerable changes in cycle length of the tachycardia (Fig, 3), the next activation wave always started immediately after the completion of the foregoing one. In the case of an automatic focus whose firing frequency is independent of the spread of activation, such a relation seems highly improbable.

\section{Acknowledgment}

We are most grateful to $\mathrm{Dr}, \mathrm{F}$. J. L wan Capelle and Dr. M. J. Janse from the Department of Cardiology and Clinical Physiology of the University of Amsterdam for their help and many hours of discussion during this study and the preparation of the manuscript. We are indebted to Prof. J. Th. $F$. Boeles and Prof. $L_{*}$ N. Bouman for their support and encouragement in this investigation and to $\mathrm{Mr}$. A. A. Meijer and Mr. A. W. Schreurs for their unfailing technical assistance.

\section{References}

1. MCWILLIAM, J.A.: Fibrillar contraction of the heart. J Physiol (Lond) 8:296-310, 1887.

2. MAYER, A.G.: Rhythmical pulsation in scyphomedusae: Part II. Papers Tortugas Lab Carnegie Institution of Washington 1:115-131, 1908.

3. Mines, G.R.: On dynamic equilibrium in the heart. J Physiol (Lond) 46:349-383, 1913.

4. Mines, G.R.: On circulating excitations in heart muscles and their possible relation to tachycardia and fibrillation. Trans R Sac Can 4:43-53, 1914 .

5. Gakrey, W.E.: Nature of fibrillary contraction of the heart: Its relation to tissue mass and form. Am J Physiol 33:397-414, 1914 .

6. RYTAND, D.A.: Circus movement (entrapped circuit wave) hypothesis and atrial flutter. Ann Intern Med 65:125-159, 1966 .

7. LewIs, T., FEIL, H.S., and STroub, W.D.: Observations upon flutter and fibrillation: II. Nature of auricular flutter. Heart 7:191-245, 1920.

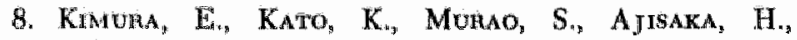
Koyama, S., AND Omrya, Z: Experimental studies on the mechanism of the auricular flutter. Tohoku J Exp Med 60:197-207, 1954 .

9. Han, J., Malozzz, A.M., and MoE, G.K.; Sing-atrial reciprocation in the isolated rabbit heart. Circ Res 22:355-362, 1968 .

10. Menoez; C., AND MOE; G.K.: Demonstration of dual A-V nodal conduction system in the isolated rabbit heart. Cire Res 19:378-393, 1966.

11. Jaxise, M.J., vain Capelle, FJ.L., Frieud, G.E., and DURaren, D: Circus novement within the AV node as a basis for supraventricular tachycardia as shown by multiple micraelectrode recording in the isolated rabbit heart. Circ Res 28:403-414, 1971.

12. DE BOEn, S.: On the fibrillation of the heart. J Physiol (Lond) 54:400-409, 1921.

13. KATZ, L.N., AND PrCK, A.: Clinical Electrocardiography: 1. Arrhythmias. Philaclelphia, Lea \& Febiger, 1956, pp 283-284.

14. BONKE, F.I.M., Bouman, L.N., AND SCHOPMAN, F.J.G.: Effect of an early premature beat on activity of the sinoatrial node and atrial thythm in the rabbit. Cire Res 29:704-715, 1971.

15. Duraren, $\mathbb{D}$., Schoo, L., Schumlenburg, R.M., aND WELLENS, H.J.J.: Role of premature beats in the initiation and the termination of supraventricular tachycardia in the Wolff-Parkinson-White syndrome. Circulation 36:644-662, 1967.

16. SANo, T., AND SCHER, A.M.: Multiple recording during electrically induced atrial fibrillation. Circ Res 14:117-125, 1964 .

17. Scherf, D: Mechanism of atrial futter and fibrillation. In Mechanisms and Therapy of Cardiac Arrhythmias, edited by L. S. Dreifus and W. Likoff. New York, Grune \& Stratton, 1966, pp 129-143.

18. Hoffman, B.F., AND Cranefield, P.F.: Electrophysiology of the Heart. New York, McGraw-Hill, 1960, p 157.

19. YAMAGish, S., AND SANO, T.: Effect of temperature on pacemaker activity of rabbit sinus node. Am I Physiol 212:829-834, 1967.

20. VInRsma, J.W.: Heart rate and conduction of the impulse in the atrium. Ph.D. Thesis, University of Amsterdam, 1969.

21. Janse, M.J., VAN der Steen, A.B.M., VAN DAM, R.T., AND Duraen, D.: Refractory period of the dog's ventricular myocardium following sudden changes in frequency. Circ Res 24:251-262, 1969. 


\title{
Circus Movement in Rabbit Atrial Muscle as a Mechanism of Tachycardia
}

\section{The Role of Nonuniform Recovery of Excitability in the Occurrence of Unidirectional Block, as Studied with Multiple Microelectrodes}

\author{
Maurits A. Allessie, M.D., Felix [. M. Bonke, M.D., and Francien J. G. Schopman
}

\begin{abstract}
SUMMARY Periods of tachycardia were induced in isolated segments $15 \times 15 \mathrm{~mm}$ ) of rablit left atrium by local application of a properly timed premature stimulus. We ussed a special device for multiple synchronous microelectrode recordings of responses of more than 100 fibers during the initiation of tachycardia. We clearly demonstrated circus movement of the impulse through a small area of atrial muscle as the anderlying mechanism. The premature impulse was conducted antegrade in only one direction, whereas in the other directions antegrade conduction falled. The local responses of the fibers in the blocked area served as a temporary obstacle for return of the premature impulse. When these fibers recovered their excitability before extinction of the premature impulst. they were rentered
\end{abstract}

IN A PREVIOUS PAPER' we reported the initial results of our studies of the mechanisms for initiation of tachycardia induced in isolated segments of rabbit atrial muscle by the application of a single premature stimulus. By

From the Deparment of Physiology. Uniwersiny of Amsterdam, Jan Swammerdam Inzthut, 1st Const. Huygensstrat 20, Arrasterdam. The Netherlands.

Sapported by the Nederiandse Hartstichting, Gravit 73-054

Address for reprints: Dr. Maurits A. Allessie, Deparment of Physiology, Biomedical Centre, University of Limburg, Beeldsnijdersdreet 101, Masstrichi. The Netherlands.

Recelved July 28, 1975: accepted for publication April 19, 1976. in a retrograde direction, and the impulse traveled hin circular route. During the propagation of a premature beat, local bloch, which sed the stage for circus movement, wats caused by nontuniform recovery of excitabiliny of the atrium. We related the spread of activation of a premature inpulse to the naturally occurring spatial dispersion in refractory periods and found that local conduction block invariably was associated with an area of dellayed restoration of excitubility. Artificial induction of differences in refractory periods by regional application of carbamylcholine made if clear that a disparity in refractory periods of only 11 - 16 msec between adjacent areas may be sufficient to cause local conduction block of a properly timed prematture impulse.

extensively mapping the spread of activation with multiple extracellular electrodes, we demonstrated that the tachycardia was based on a circus mowement of the impulse. through a small area of atrial muscle. This circus movement was initiated when (1) the premature impulse was conducted only in one direction and was blocked in other directions, and (2) the resulting circuitous propagation of the premature impulse took so much time that excitability was restored in the area in which the impulse was initiated at the moment it was reentered by the returning activation wave.

In this paper we are reporting more detailed information 
on circus movement tachycardia in the atrium as obtained from multiple microelectrode recordings. Furthermore, as the accurrence of unidirectional block is the first requisite for the onset of circus movement, we investigated the circumstances under which local block may occur. Several factors might be important for the occurrence of unidirectional block: (1) nomuniform arrangement of the atrial fibers, (2) differences in the membrane responsiveness of atrial fibers, and (3) spatial dispersion in recowery of excitability. Studies on electrical activity of single cardiac fibers have shown that local conduction delay or complete failure of propagation of premature impulses can occur at the junction of two areas in which the action potentials differ in duration. ${ }^{2-*}$ Such conduction disturbances are observed when excitation in one area precedes recovery of excitability in an adjacent area. Direct determinations of refractory periods have revealed that under physiological conditions fibers in the atrium and the ventricle may have considerable variability of refractory periods. To evaluate this possible explanation for unidirectional block, we measured refractory periods at numerous sites in the atrium around the point at which a properly timed premature stimulus evoked tachycardia. These measurements were correlated with the spread of excitation during the onset of tachycardia. In addition, differences in refractory periods were induced artificially and the minimum dispersion in recovery of excitability required for the occurrence of local block was established.

\section{Methods}

We studied isolated segments $(15 \times 15 \mathrm{~mm})$ of the rabbit left atrium. The preparations consisted of the roof of the atrial appendage and part of the adjacent left atrium. Most of the interatrial band and that part of the left atrium containing the entrances of the pulmonary veins were dissected and discarded. A number of experiments were performed in which differences in refractory periods were induced artificially. In these experiments isolated pectinate muscles, excised from the left atrial wall were used. The bundles were about $10 \mathrm{~mm}$ long and less than $1 \mathrm{~mm}$ in diameter. The preparation. perfusion fluid, and stimulation and recording techniques were the same as those described previously." Because of the absence of any spontaneous activity, the preparations were driven at a regular rate (interval $500 \mathrm{msec}$ ) by applying constant voltage stimuli (duration, $1 \mathrm{msec}$, intensity, 2 times threshold) between a silver wire (diameter, $0.4 \mathrm{~mm}$, insulated to the tip) placed on the tissue and an $\mathrm{Ag}-\mathrm{AgCl}$ strip immersed in the perfusion fuid. To induce tachycardia, a test stimulus (duration 1 msec, intensity 4 times threshold) was introduced through the same electrodes after every 20 th basic stimulus. In most of the preparations it was possible to identify one or more sites at which a properly timed premature stimulus repeatedly evoked a period of tachycardia. One or more surface electrodes were used as reference leads to ascertain whether the spread of activation during the onset of different episodies of tachycardia was the same.

\section{MULTIPLE MICROELECTRODE RECORDINGS}

To study the spread of activation of the premature beat and the subsequent beats in the tachycardia, multiple microelectrode recordings were made around the primary site of stimulation. Figure 1 shows the device we used to facilitate this procedure. Microelectrodes arce placed in 10 separate holders which can be adjusted concentrically. The diameter of the circle formed by the points of the microelectrodes can be varted from $0.510 .15 \mathrm{~mm}$. Furthermore, the position of the electrodes can be changed radially over an angle of $36^{\circ}$. By attaching this device to a micromanipulator and placing a stimulating electrode in the center of the ring. it is possible to make simultaneous recordings that are equidistant from the site of stimulation. However, it must be emphasized that the advantage of this technique, that is, the ability to make multiple simultaneous intracellular recordings, is, to some extent, tempered by a loss of quality of the individual impalements. Therelore, the value of the method for measuring absolute values of many tiction potential characteristics is linited. For that reason we felt it unwarranted to try to measure absolute values of resting potential, takeoff potential, amplitude and rate of rise of phase zero of the action potential. On the other hand, for the study of changes in the response of individual fibers at the onset of tachycardia relative to the action potentials recorded during basic rhythm, the method is quite useful.

\section{MEASUREMENTS OF SPATIAL DISPERSION IN REFRACTORY PERIOD}

To determine whether nonuniform recovery of excitability played a role in the genesis of circus movement, we measured refractory periods at multiple sites in the atrial myocardium. The stimulation pattern described abowe was used. At each test point, premature stimuli (4 times threshold) were applied at progressively longer intervals. The shortest interval between the basic stimulus and the test stimulus that resulted in a propagated premature beat was taken as the time required by cells at that particular site for restoration of sufficient excitability to permit a response to at stimulus that was 4 times threshold. The values obtained in this way represent a standardized measurement of part of the relative refractory period. Reproducibility of measure ments was checked frequently, Control measurements at the same site after 1 hour resulted in a variation of less than 5 msec.

\section{ARTIFICIAL INTRODUCTION OF DIFFERENCES IN REFRACTORY PERIODS}

To obtain information about the difference in recovery of excitability that is required to induce unidirectiomal block of a premature impulse, restoration of excitability was enhanced artificially in one part of the preparation. For these experiments isolated pectinate muscles were used because of their relative homogeneity of geometry and electrophysialogical propertics. The muscle bundles were put in a tissue bath, comsisting of two compartments, separated by a thin rubber membrane. The muscle was pulled through a small perforation in this membrane. The two compartments were perfused by separate perfusion systems. Temperature and perfusion rate were kept constamt and equal in both compartments at $37^{\circ} \mathrm{C}$ and $50 \mathrm{ml} / \mathrm{min}$ respectively. By adding carbamyllcholine to the perfusion fluid of one compartment, both the effective and the relative refractory periods were 


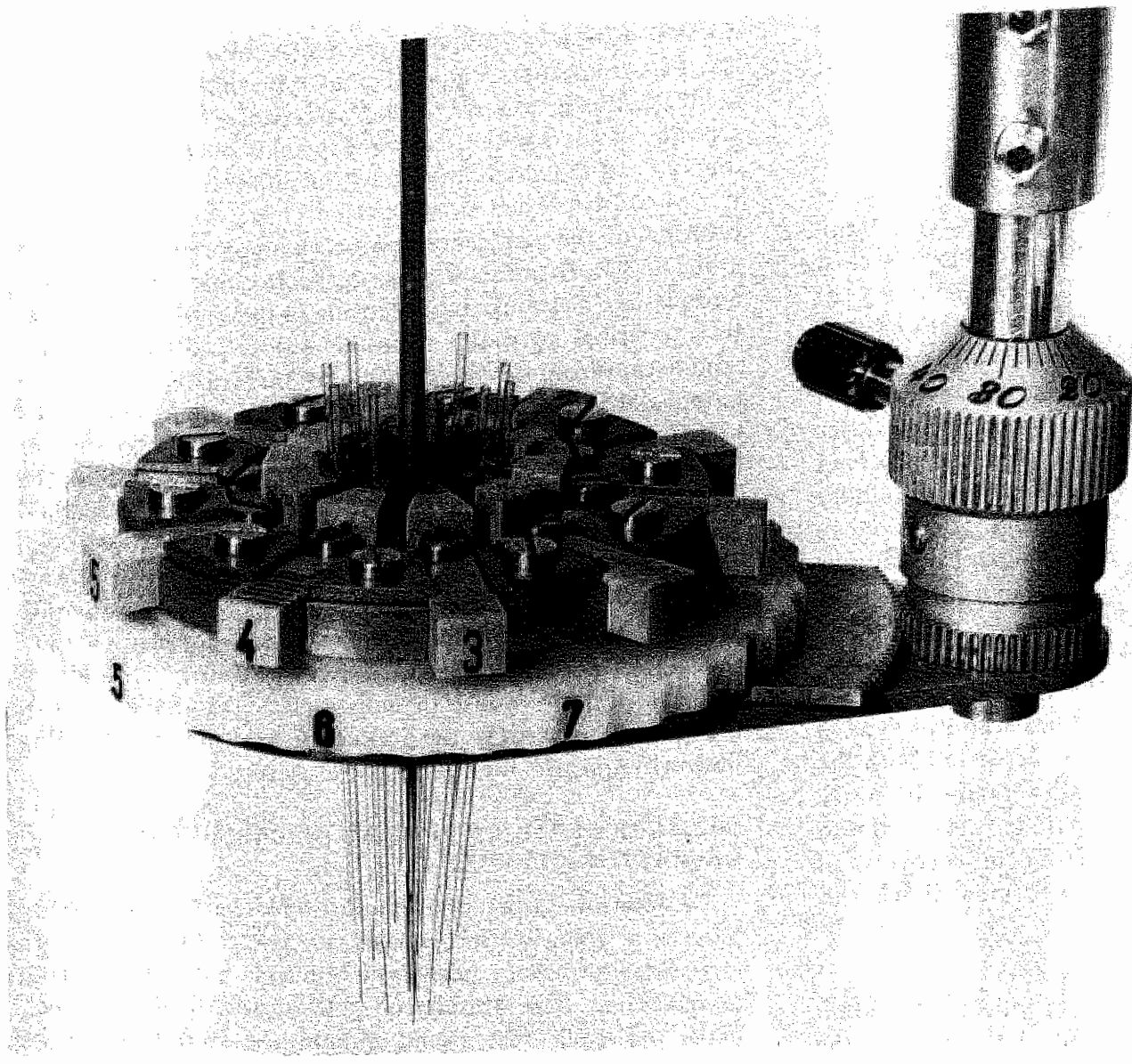

Ficure I Pholograph of the dewice for intracellular recording in 10 cells. The microelectrodes are fixed in individual holders which are mounted on a ring. By turning the large white wheel the position af the microelectrodes can be adjusted comcentrically. With the pinion shown at the right the microelecrrodes can be moved radially over an angle of $36^{\circ}$. A suimwlating electrode is pasi tioned in the center of the microelectrodes. shortened in the part of the muscle studied. A concentration or $0.1 \mu \mathrm{g} / \mathrm{mll}$ wsually was sufficient to enable the induchion of exrly premature beats which falled to propagate into the purt of the preparation in the other compartment. After unidirextional block occurred the carbanylcholine concentration was decreased gradually until all premature beats were conducted again. By comparing measurements of the refractory periods at both sides of the separating membrane, just before and after the disappearance of conduction block, the minimum dispersion in refractory periods required for the occurrence of unidirectional block could be determined.

\section{Results}

\section{MULTIPLE MICROELECTRODE RECORDINGS DURING THE INTTIATION OF TACHYCARDIA}

In four of 22 experiments we obtained enough intracellular recordings to describe impulse propagation during the initiation of tachycardia. The results of a representative experiment are shown in figure 2. In this experiment runs of tachycardia were elicited repeatedly during a period of more than $1 / 2$ hour by the application of a premature stimulus 65 msec after every 20 th basic stimulus Maps of the spread of activation during basic rhythm, the premature beat, and the first 2 beats of the tachycardia are shown at the top of the figure. The dramatic change from a more or less radial spread of activation during basic rhythm into a circus movement of the impulse during the premature beat and the subsequent tachycardia is the same as described earlier." However, wh the intracellular recordings now available, it is possible to trace the spread of activation more accurately. This is especially true in those areas where conduction has slowed down or is blocked completely. At the bottom of figure 2, the premature impulse was propagated in the direction of pairs $A$ and $B$ without any sign of decrement. However, in directions $C-F$ conduction of the premature impulse occurred with decrement, resulting in local conduction block. The proximal fiber of pair $C$ exhibited a small local response immediately after the premature stimulus. This consisted of a depolarization of small magnitude, slow-rising velocity, and short duration." This response failed to excite the more distal fiber, which was not even influenced electrotonically. Somewhat later (34 and $43 \mathrm{msec}$ after the premature stimulus) both fibers of pair $C$ were activated by the wavefront coming from the area where conduction of the premature impulse was successful (A-B). Obviously, there was sufficient recowery of excitability of the proximal fiber in pair $C$ to permit generation of an action potential. At sites $\mathrm{E}$ and $\mathrm{F}$ the fibers close to the stimulating electrode (upper trace) were activated by the premature stimulus with a delay of 13 and $20 \mathrm{msec}$ respectively. However, compared with the action potentials recorded from these fibers during basic rhythm, the premature responses were of substantially smaller amplitude and rate
of rise. 
BASIC BEAT

(interyal $500 \mathrm{msec}$

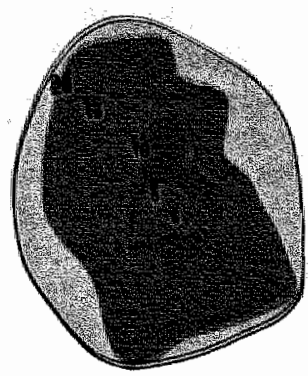

PREMATURE BEAT

Helay b5 msec)

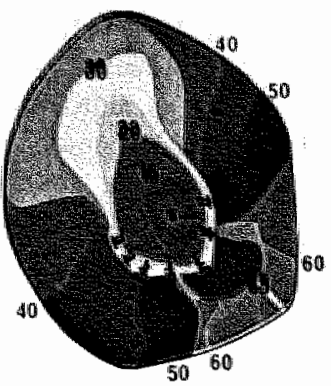

TACHYCARDIA

"irst cycto

Socond cycte

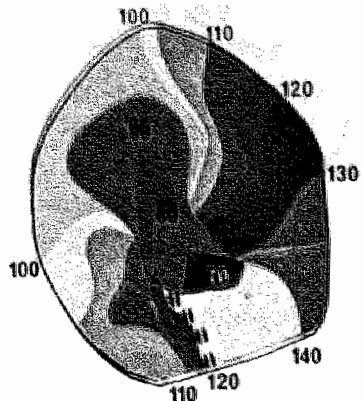

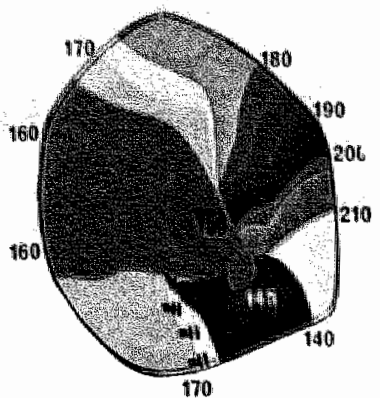
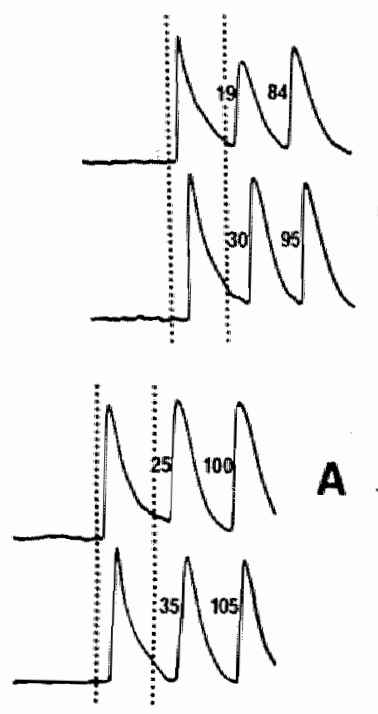

A

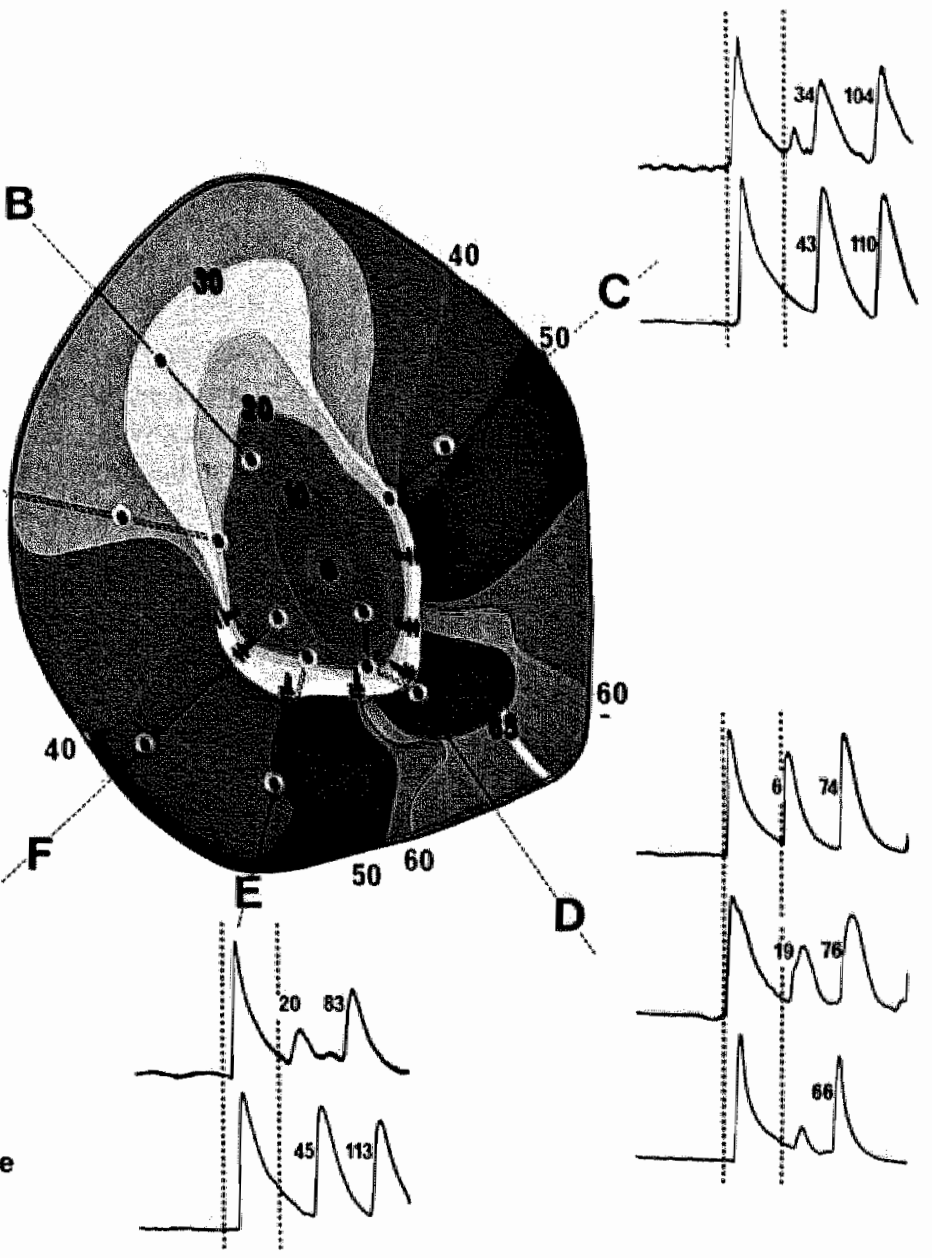

C
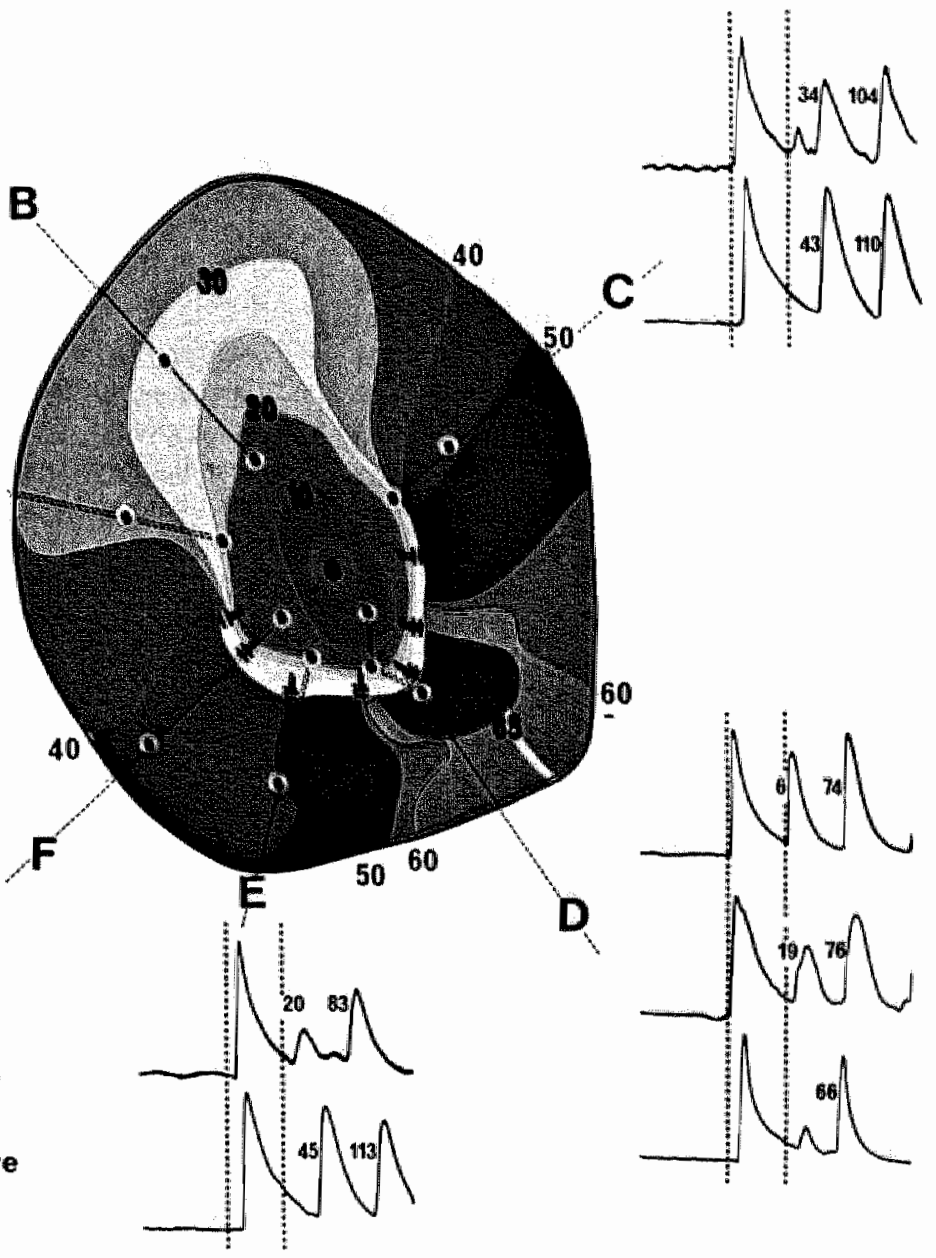

A

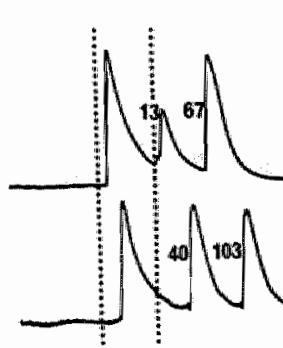

basic premature

stim. stim.

\section{$5 \mathrm{~mm}$}

FUGURE 2 TOp: Maps of the spread of activation during regular (basic) driving of the preparation, the induction of a premature beat, and the first two cycles of a resulting period of tachycardia. The site of stimulation is indicated by a black dol. Acvivation times from more than 100 fibers were measured, and the parts of the preparation activated at about the same time (within 5 mstec) are indicated by different colars. During basic rhythm the moment of the basic stimulus was taken as zero while in the other maps the activation times are related to the moment of the premature stimulus. Double bars indicate conductiom block. Bottom: Pairs of transmembrane potentials (A -F) recorded around the site of stimulation are shown around the map of the premature beat. The upper trace of each pair is recorded from a fiber close to the stimulating elecurode, while the lower traces represent fibers farther away fram the point of stimulation. The exact pasition of the fibers is indicated on the map. All records start with the last action potential of the regularly driven rhythm (interval $=500 \mathrm{msec}$ ). Vertical douted lines indicate the moments of the last basic stimulus and the test stimulus, respectively. The activation times in milliseconds, added to the recordings are measured from the momert of the premature stimulus. 
This strong decay of the "stimulating efficacy" of phase 0 of the action protential resulted in local conduction block of the premature mpulse. This also is seen in the remarkable shorteming of the duration of the premature responses in these nbers. Accordinglly, the more peripheral fibers of pairs $\mathrm{E}$ and $\mathrm{F}$ (lower traces) were not activated in a direct way. The action potentials generated by these fibers at 40 and 45 msec affer the test stimulus were elicited by the wavefiront turning counterelockwise. At this moment, however, reentry of the proximal fibers of $E$ and $F$ was not yet possible. The relatively large local responses exhibited by these fibers apparently prevented their reexcitation. The proximall fiber of pair $E$ showed only a very small ellectrotonic hump stiorly after the distal fiber was discharged. From area D, transmembrane potentials of three fubers at different distances from the stimulating electrode are shown. The most proximal fiber (top trace) was depolarized $6 \mathrm{msec}$ after the premature stimulus, the action potential being of relatively thigh amplitude and rate of rise. However, a little more to the periphery (middle trace), the premature impulse already had lost much of its stimulating efficacy, while in the most distal fiber (bottom trace) only an electrotonic hump was recorded. This latter fiber was activated with a delay of 66 msec by the activation wave coming from the opposite side of the preparation. Because of the long delay the impulse now cowld reenter the proximall fibers $(74$ and 76 msec after the test stimulus) despite the fact that they already had been excited. These records not only show the nature of unidirectional block in atrial muscle, they also demonstrate that the area where the impulse is blocked may serve as a temporary obstacle for the impulse to circumvent. The local responses associated with conduction block apparently prevent an early lateral invasion of the blocked area by the turning impulse.

The minimal length of the circular pathway described above is determined by al leasl two factors." the rate of recovery of excitability and, party associated with it, the conduction velocity of the impulse. When the recovery of excitability proceeds rapidly or the conduction velocity of the impulse is slow, the minimal length of the circular pathway can be small. Therefore the possibility of circus movement in very small areas of atrial muscle, as demomstrated in these experments, is enhanced by the observed slowing of the conduction velocity of the impulse during the premature beat and the succeeding tachycardia (compare the maps in Fig. 2). As can be seen in Figure 3, this slowing of propagation may result at least in part from a decrease in efficacy of the action potential as a stimulus. Both amplitude and rate of rise decrease during the tachycardia. These changes in phase 0 of the action potentiall partly can be explained by Weidmann's observation ${ }^{13}$ that the rate of rise and the overshoot of phase 0 depolarization in Purkinje fibers depend on the takeoff potential. Since during tachycardia the atrial fibers did not repolarize fully, the takeoff potential was lower, resulting in a decrease in the rate of rise and the amplitude of the action potentials (Fig. 3).

\section{NONUNIFORM RECOVERY OF EXCITABILITY AND UNIDIRECTIONAL BLOCK OF A PREMATURE IMPULSE}

Many studies of canine and rabbit hearts have shown that atrial muscle fibers may differ considerably with respect to action potential configuration and duration. Some authors have distinguished two types of atrial fibers: atrial myocardial fibers and the so-called plateau fibers. ${ }^{2}$ In Figure 4 the action potentials of six different atriall fibers in one preparation are superimposed. The distance between these particular fibers was less than $5 \mathrm{~mm}$. The figure shows that in our preparations there was a wide variation in configuration and duration of the action potentials: however, two distinct types of muscle fibers could not be distinguished. This variation in shape and duration of the action potential suggests the presence of a considerable spatial dispersion in the rate of

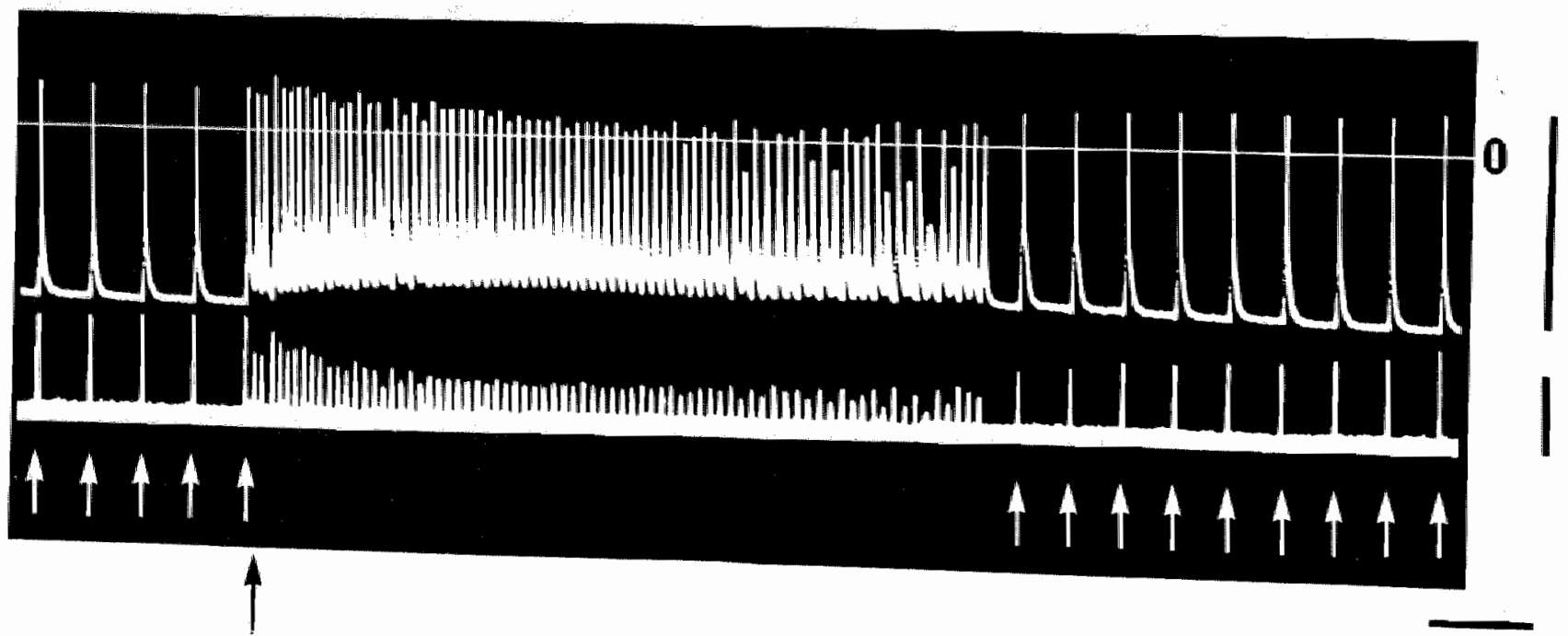

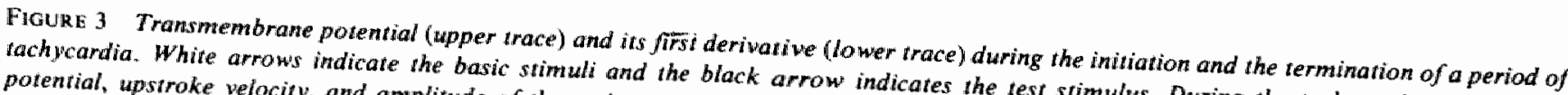
potential, upstroke welociry, and amplitude of the action potential all decrease. During this stimulus. During the tachycardia, the takeoff valwes. Calibration. When basic rhythm was resumed, takeoff potential, dV/dt

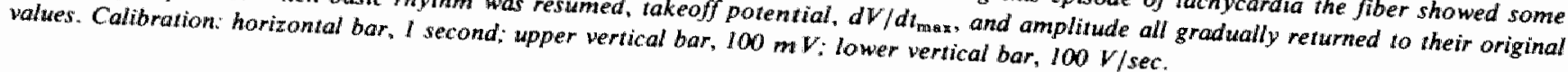




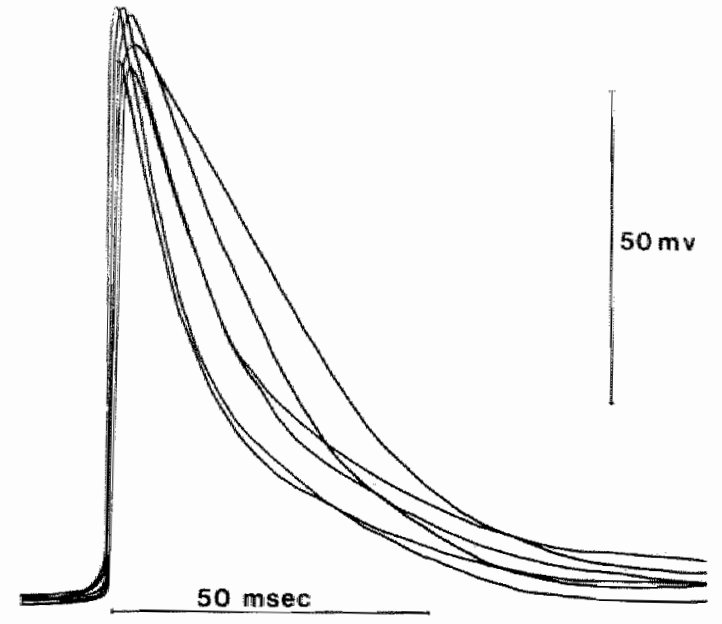

Figure 4 Superimpased action potentials of six different atrial muscle fibers recorded within an area of $25 \mathrm{~mm}^{2}$ during regular driving of the atrium (interval $=500 \mathrm{msec}$ ). There are considerable: differences in duration of the action potentials, none of thent showing a distinct plateau phase during repolarizanion.

recovery of excitability. To study whether nonuniform recovery of excitability in atrial muscle was important for the initiation of circus movement, we measured refractory periods at numerous sites in the preparation. We found that in most preparations there was considerable dispersion in the recovery of excitability, the difference between the shortest and longest refractory periods amounting to about $30 \mathrm{msec}$. In preparations in which there was more or less uniform restoration of excitability, it was difficult or even impossible to find a stimulus site at which tachycardia could be induced. On the other hand, those premature stimuli that initiated tachycardia always were given on the border between two areas with distinctly different refractory periods. Furthermore, in relating the spread of the premature impulse which initiated circus movement, to the dispersion of refractory periods of the preparation, it was apparent that the premature impulse always propagated in the direction of the sites with shorter refractory periods, while it was blocked in the direction in which refractoriness was of greater duration (Fig. 5).

Although these results strongly suggest that spatial dispersion in refractoriness played a crucial role in the occurrence of local block, definitive proof of a causal relationship needs the additional evidence that the observed degree of nonuniform recovery of excitability per se was sufficient to produce unidirectional block of a premature impulse. In other words, one should know the minimal difference in refractory period between adjacent areas of the atrium which is necessary to inhibit propagation of a premature impulse. In an attempt to provide such evidence, experiments were carried out on pectinate muscles isolated from the left atrium. In these bundles dispersion in refractory periods was introduced artificially by superfusion of one half of the muscle with carbamylcholine (see Methods). Under these circumstances it was possible to elicit early premature impulses in the segment of muscle superfused with carbamylcholine which were not propagated through the remainder of the muscle. An example of such artificially evoked unidirectional block is shown in Figure 6. The refractory periods along the bundle are plotted in the schematic drawing of the preparation at the top of the figure. The induced difference in the refractory period between the two parts of the bundle was about $24 \mathrm{msec}$. The stimulating electrode was placed close to the separating membrane on the side of the bundle superfused with carbamylcholime. At both sides of the preparation surface electrograms were reconded with bipolar leads ( $A$ and $B$ ). To record propagation and the occurrence of unidirectional block multiple microelectrode recordings were made in the normal part of the bundle. A premature stimulus applied 63 msec after the basic stimulus initiated an impulse which was conducted to the left side of the preparation, as can be concluded from the premature complex recorded at lead $\mathrm{A}$. In contrast, lead $B$ at the right side of the preparation did not record any premature activity. Between sites 1 and 2 the conduction of the premature impulse was delayed. This delay in activation was associated with an initial slight increase in the takeoff potential and amplitude of the premature response at site 2. However from this site on, in the direction of lead $B$, amplitude, rate of rise and duration of the premature response all decreased gradually until the impulse died out somewhere between sites 4 and 5 .

To determine the minimal dispersion in refractory periods sufficient for the occurrence of local block, the carbamylcholine concentration was lowered gradually until the unidirectional block disappeared. At each carbamylcholine concentration refractory periods were measured at both sides of the separating membrane. Also the period in the basic cycle at which unidirectional block of a premature impulse occurred was determined. Figure 7 shows the differences in refractory periods at three carbamylcholine concentrations together with the responses of the two parts of the bundle to stimuli of different prematurity. At a carbamylcholine concentration of $0.1 \mu \mathrm{g} / \mathrm{m}$ unidirectional block occurred for premature impulses elicited between 52 and $72 \mathrm{msec}$ afler the basic stimulus. After the carbamylcholine concentration was decreased to $0.06 \mu \mathrm{g} / \mathrm{ml}$ the difference in refractory periods diminished to $11 \mathrm{msec}$. This degree of dispersion in refractory periods still resulted in unidirectional block. Howewer, the period in the basic cycle in which premature impulses were blocked now was narrowed to an interval of $10 \mathrm{msec}$, ranging from 63 to $73 \mathrm{misec}$ after the basic stimulus. At a carbamylcholine concentration of $0.05 \mu \mathrm{g} /$ m.l, the difference in refractory periods was only $8 \mathrm{msec}$. This was no longer sufficient to cause unidirectional block.

Thus, in this case, the minimal difference in refractory periods necessary for unidirectional block of a properly timed premature impulse can be estimated as between 8 and $11 \mathrm{msec}$. To exclude preexistant preferential conduction in one direction, in some experiments the procedure was repeated, adding the carbamylcholine to the other compartment. There was no indication of the presence of important asymmetry in conduction. The results of 14 experiments are summarized in Table 1 . On the average the minimal dispersion in the refractory period for the occurrence of local block was between 11 and $16 \mathrm{msec}$. Because this falls largely within the range of the naturally occurring differences in refractory periods, which in our preparations were up to $30 \mathrm{msec}$, it can be concluded that the nonuniform 


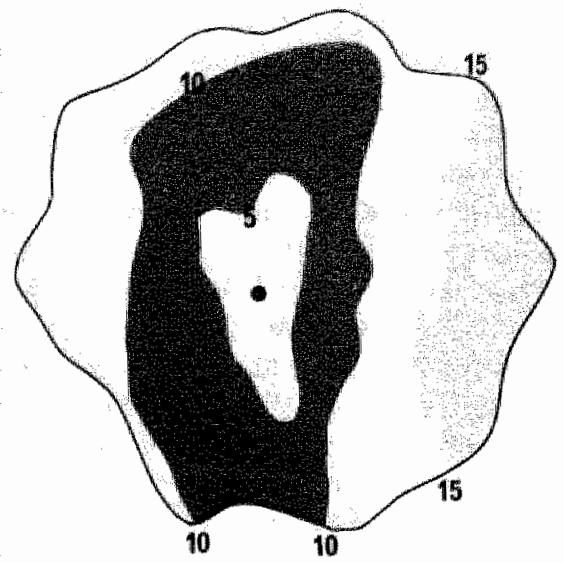

TACHYCARDIA first cycle

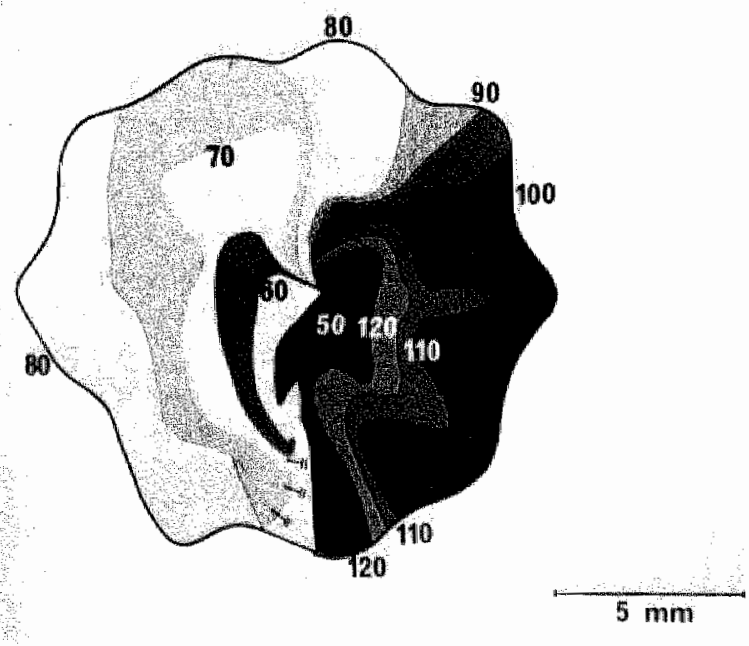

PRERATURE BEAT

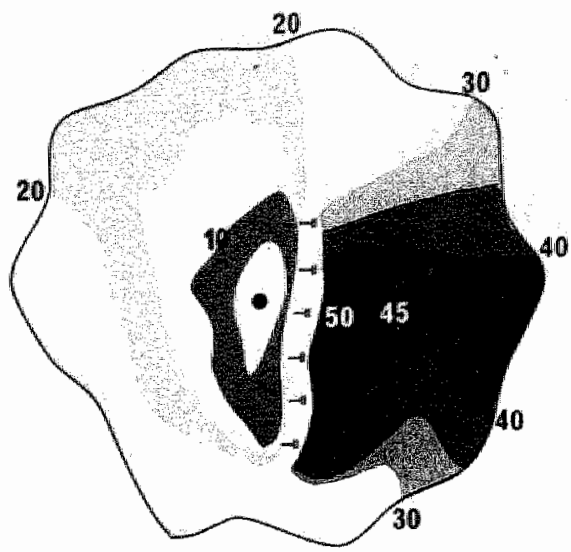

REFRACTORY PERIOD

DURING BASIC RHYTHM

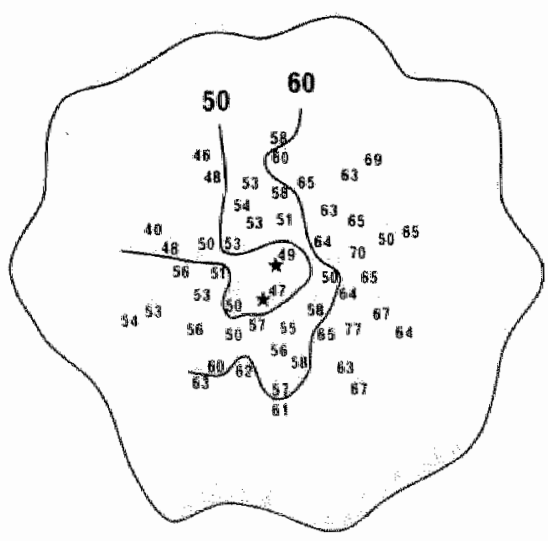

Ficurts 5 Maps of the spread of actwation during the onset of tachycardia and of the refractory periad during basic rhythm. The sines of the preparation at which a premature stimulus elicted tachycardia are indicated by asterisks. The activation simes given at the outer borders of the maps refer to the mowent of the basic stimulus (basic beat) and she moment of the rest stimulus, respectively (prentature beat and first cycle of tachyeardia).

recovery of excitability which occurred spontaneously in the atrium was of decisive significance in the origin of unidirectional block and therefore in the onset of circus movement tachycardia.

\section{Discussion}

\section{SIGNIFICANCE OF DISPERSION OF REFRACTORY PERIOD IN THE GENESIS OF TACHYCARDIA AND FIBRILLATION}

Differences in refractory periods have been demonstrated among various parts of the heart, e.g., at the junction between the sinoatrial and atrioventricular nodes with the atrial myocardium, ${ }^{6}$ at the Purkinje fiber-muscle junc- tion, 4.5 and in the myocardium itself. During regular driving of the heart, Han and Moe and Janse found differences of up to 30 msec between the longest and shortest refractory periods in ventricular muscle. In the right atrium of the dog Alessi et al. "reported a variation of $40 \mathrm{msec}$, whereas Zipes et all. "recently found that the largest difference in refractory periods between seven locations in the canine right and left atria varied between 25 and $110 \mathrm{msec}$ (average, 60 msec). These authors ${ }^{10,11}$ also found that this inhomogeneity was increased further by vagal stimulation. Ninomiyal argued that this was based on nonuniform distribution of vagal fibers in the atria. In the isolated left atrium of the rabbit we found differences in refractory 
periods of up to $30 \mathrm{msec}$. This degree of disparity in recovery of excitability thus is rather moderate compared to the results of other investigators.

The concept that nonuniformity of refractory periods may
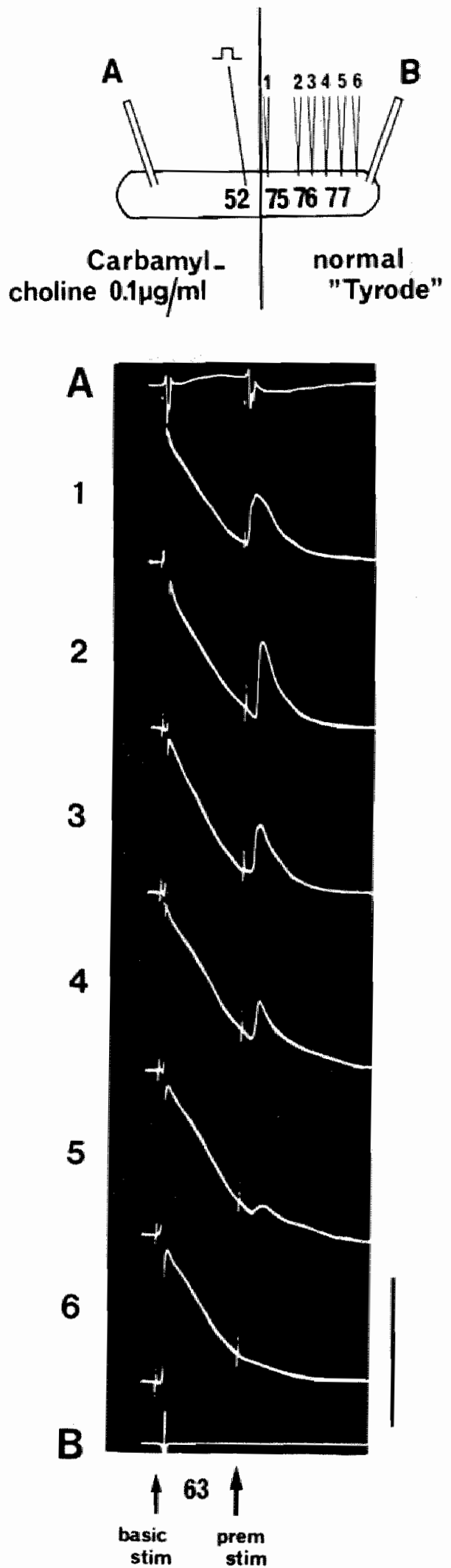

play a key role in the initiation of tachycardia and fibrillation was described as early as 1913,15 and since then the significance of dispersion af refractory periods in the genesis of tachyarrhythmias has been emphasized repeatedly. ${ }^{4-11,16-19}$ However, in only a few studies have attempts. been made to link spatial disparity in recovery of excitability directly to reentrant activity." 20 " Even less information is available on what differences in refractory periods between two adjacent areas are required as a minimum for the occurrence of local block. We associated the spread of a premature impulse, imitiating circulating excitation, with the spatial dispersion of refractory periods. This revealed that local block of the premature impulse invariably was linked with the presence of an area of delayed restoration of excita* bility. Artificial introduction of differences in refractory periods in isolated pectinate muscles by local administration of carbamylcholine made it clear that a difference in refractory periods of only $11-16 \mathrm{msec}$ between neighboring areas in the atrium is sufficient to create local conduction block of an early premature beat. We therefore concluded that the physiological dispersion in refractory periods described in the atrium ${ }^{10-11}$ seems to be adequate to create a reas of block during the propagation of early premature impuises.

\section{LOCAL CONDUCTION BLOCK AS THE CENTER OF CIRCUS MOVEMENT}

The finding that relatively small differences in refractory periods may cause conduction block raises the following questions: Why does reentrant activity not occur more frequently in the normal heart, and why on many occasions did we fail to find a site at which a properly timed premature stimulus could evoke a period of tachycardia, despite the presence of apparently sufficient dispersion in refractory periods? To answer these questions one must bear in mind that for the creation of local reentrant pathways another additional condition is required: The site at which conduclion of the premature impulse is blocked must be activated with such delay that excitability is restored in the fibers proximal to the block. Only then can reentry occur through these fibers. The relatively long delay that occurred before retrograde activation of the blocked area in our experiments may not be explained merely by slow conduction of the premature impulse. Cramefield and Hof fman ${ }^{23}$ have found that conduction of an impulse can be intibited in fibers which show small local responses. The small local responses

Figuet 6 Demonstration of tocal block of propagation of a premature impulse. At the top is a schematic drawing of the experimental preparation. In the right compariment, containing the normal perfusion solution, the refractory period of the atrial bundle was about 76 msec. Perfusion of the left compariment with carbamylcholine $(0.1 \mu \mathrm{g} / \mathrm{ml})$ shortened the refractory period to $\$ 2$ msec in that part of the muscle. Electrograms were recorded at bon ends of the bundle surface (marked $A$ and B). In the normal part of the muscle muluiple microelectrode recordings were made on at straight line from the separating membrane lo lead $B$. The recordings show that an early prewature impulse elicited on the left side of the separating membrame gradwally falled to conduct to the right segment of the bundle, resulting in complete block of propagation. 


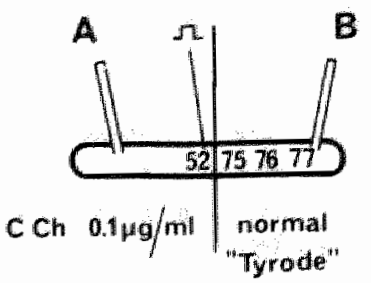

\section{A}

B

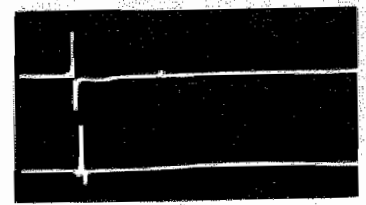

52

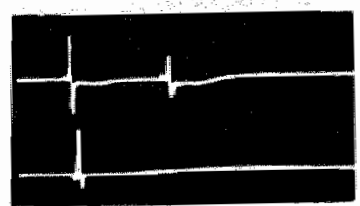

70

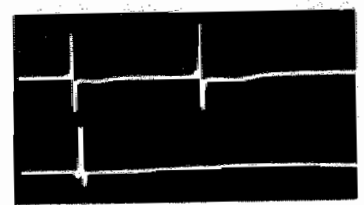

73

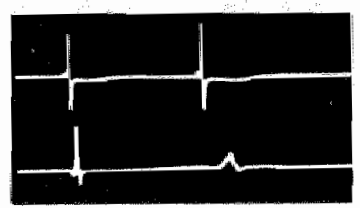

80

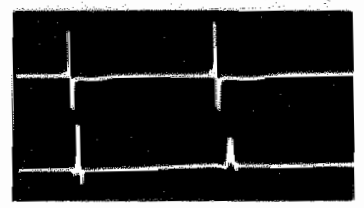

90

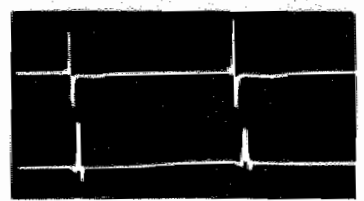

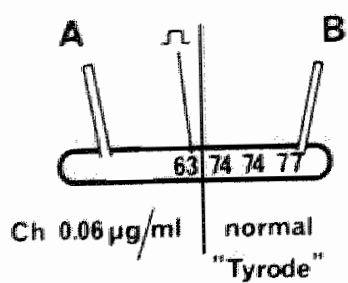

62

A

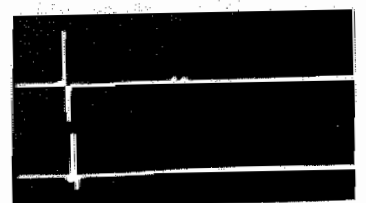

63

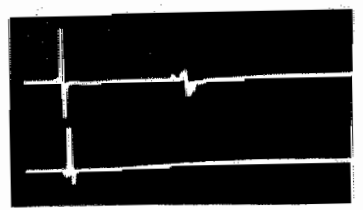

70

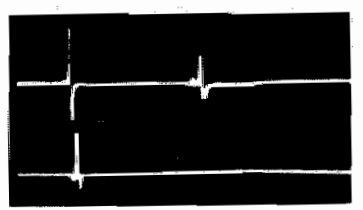

75

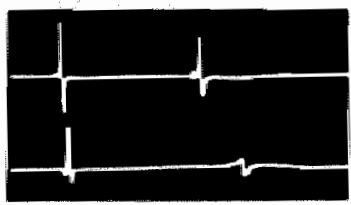

80

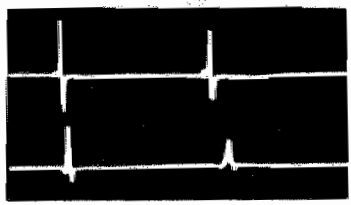

90

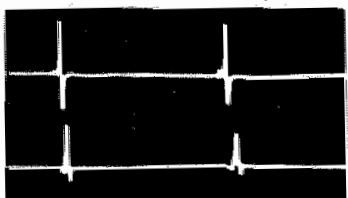

A

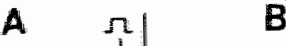

B
68

A

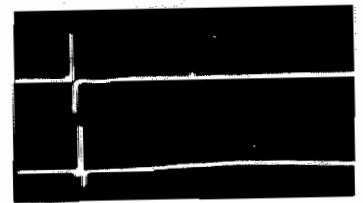

70

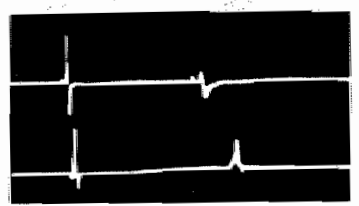

75

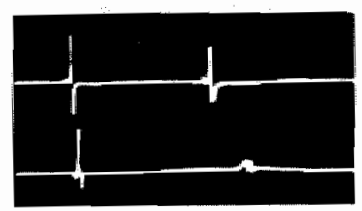

80

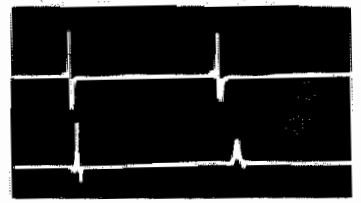

90

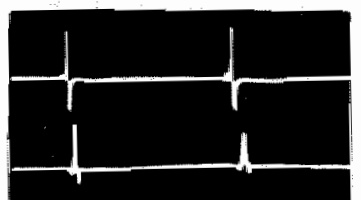

Figuk: 7 Determination of the minmal dispersion in refractory periods necessary for the occurrence of local block. Al the top, refractory periods at bork sides of the separating membrane are given for three carbamylcholine (C Ch) concentrations in the left part of the bundle $(0.1$, 0.06 , and $0.05 \mu \mathrm{g} / \mathrm{ml}$ ). The difference in refractory periods, induced in this way, was $23 \mathrm{msec}, 11 \mathrm{msec}$, and 8 msec, respectively. Beneath the schematic drawing of the preparation, ane shown the responses of both sides of the bundle to stimuli of different prematurity, applied to the carbamylcholine-containing part of the muscle.

that occurred in our studies (e.g., the upper tracings of pairs E and $F$ of Figure 2) were followed by some degree of refractorimess. This may explain why, despite the absence of an anatomical obstacle, the premature impulse was forced around the region of local block. Only after excitability was restored in the fibers in the blocked region were they activated retrogradely (site $D$ in Fig. 2). An area of local block thus may not only lead to unidirectional conduction of a premature impulse, it also may serve as a temporary obstacle around which the impulse must travel.

\section{DIMENSIONS OF THE SITE OF LOCAL BLOCK AS THE DECISIVE ELEMENTS IN THE CREATION OF} REENTRANT PATHWAYS

Whether the occurrence of local block will result in reentry depends on several circumstances, including the 
TABLE 1 Results of 14 Experiments in Isolated Pectinate Murcles
Dufference in refrectory periods not resulting in loeal conduction block

Experiment (msec)
Difference thefractor periods resulting in local condiction block (msec)

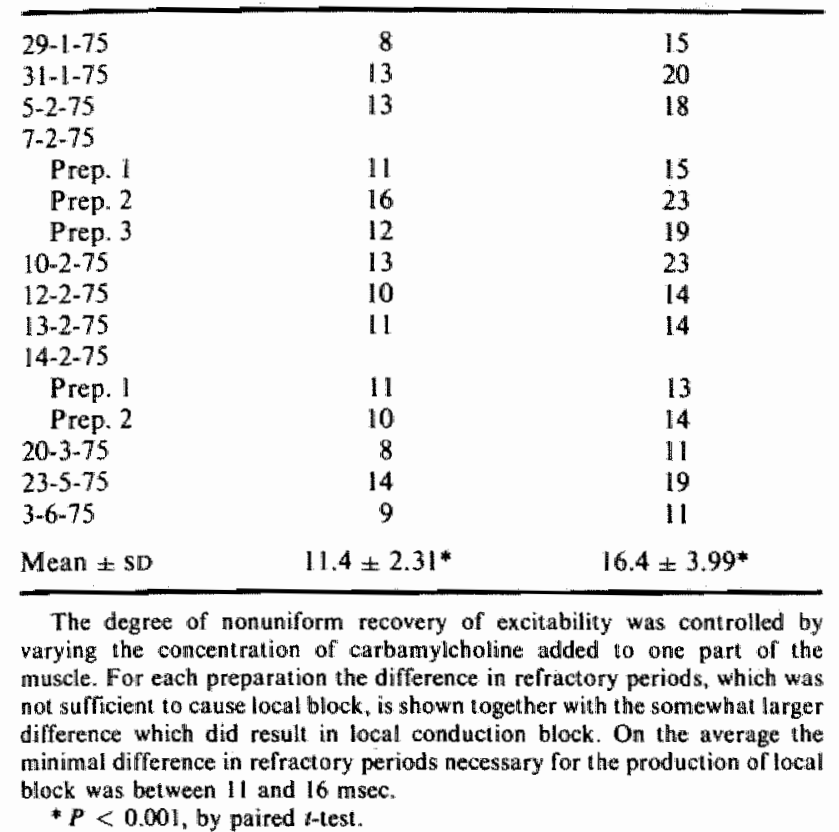

conduction velocity of the impulse, the duration of the refractory period, and the length of the circular pathway. In the presence of a central anatomical barrier, the length of the circuit is given by the perimeter of the obstacle. However, when such a preformed circular pathway is not involved, the dimensions of the area of local block will largely define the length of the circuit. When the conduction velocity of the impulse is high or the refractory period is long, in most cases only an "island" of block will result. For the production of reentry under these circumstances a large area of block would be required to force the impulse in a relatively long, circuitous route. On the other hand, when conduction is depressed or the rate of recovery of excitability is enhanced, a small area of block may be sufficient to cause reentry. This implies that the dimensions of a site of local block will be of great importance for the question of whet her or not reentry will occur. Hence, it seems that the opportunity for reentry is not determined solely by the degree of dispersion of refractory period - which under normal conditions may be sufficient-but especially by the extension of an area in which the refractory period is prolonged. We found that only when the site of delayed restoration of excitability was large enough, could reentry occur. On the other hand, when, despite the presence of great disparities in refractory period, there were only small patches of prolonged refractoriness, there was not much chance of reentry.

It therefore seems questionable that the measurement of the differences between shortest and longest refractory periods is the decisive indicator of the risk of development of tachyarrhythmias. Also, the spatial distribution of these differences has to be taken into account. In this light, the suggestion of Han and Moe, that interventions which facilitate the induction and perpetuation of tachycardia and fibrillation (such as vagal of sympathetic stimulation, ouabain or quinidine intoxication, hypothermia and myocardial ischemia) exert their arrhythmogenic action by an increase in temporal dispersion of the recovery of excitability, has to be extended. It is quite possible that the abovementioned interventions might favor reentrant activity, not only by increasing the dispersion of refractory periods, but also by changing conduction velocity and refractory periods in such a way that the minimal length of a eircuit in which the impulses can circulate is reduced. Then, also relatively small areas of local block may start to serve as a functional obstacle for the premature impulse to circumvent, which apparently would increase the chance of reentrant activity.

\section{Acknowledgments}

We are grateful to Dr. Fu I. wan Capelle and Dr. M.d. Jange from the Department of Cardiology and Clinical Physiology of the Uniwersity of Amsterdam for their help and many hours of discussion during this study. We also thank Prof. Dr. J.Th.F. Boeles and Prof. Dr. L.N. Bouman for their support and encouragement in this investigation, and A.W. Schreurs and A.A. Meijer for their unfailing technical assistance.

\section{References}

1. Allessie MA, Bonke FIM, Schopman FJO: Circus movement in tabbit atrial muscle as a mechanism of tachycardia. Circ Res 33:54-62,1973

2. Hogan PM, Davis LD: Eloctrophysiological charactaristics of canine atrial plateau fibers. Circ Res $28: 62-73,1971$

3. Kao $\mathrm{CY}_{\text {n }}$ Hoffman $\mathrm{BF}$ : Graded and decremental response in lheart muscte fibers. Am I Physiol 194: 187-196, 1958

4. Sasyniuk Bd, Mendez C: A mechanism for reacentry in caminte ventricular Visste. Circ Res 28: 3-15, 1971

5. Mendez $\mathrm{C}_{n}$ Mueller $W \mathrm{~J}_{\mathrm{n}}$ Merideth $J$, Moe $\mathrm{GK}$ : Interaction of transmen: brane potentials in canine Purkinje libers and a Purkinje fiber-muscle junctions. Circ Res 24: 361-372, 1969

6. Strauss HC, Bigger JT: Electrophysiological properties of the rabbit sinoatrial perinodal fibers. Circ Res 31: $490-506_{4} 1972$

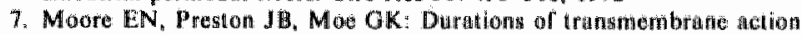
polentals and fumctiond refractary periods of canine false tendon and

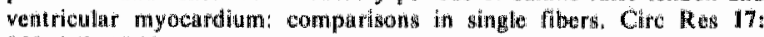
$259-273,1965$

8. Han J, Moe GK: Nonumiform recovery of exoildbility ir vontricular mascle. Ciro Res 14:44-60, 1964

9. Janse MJ: The effect of changes an heart rite on the ref ractory perion of the heart. Thesis, Amsterdim, Mondebl-offsetdruk keri., 1971

10. Alessi R, Nusynowita M, Abildshow JA, Moe GK: Nanuniform diatribution of wagal effects on the sirial refructory period. Am I Physiol 194: $406 \div 40,1958$

11. Zipes DP, Mithalick MJ, Robbins GT: Elfects of selectiwe wagal and stellate gangliom stimulaion on atrial retrictopiness. Cardiowac Rer $647-655,1974$

12. Schreurs AW, Selij APL, Allesiue MA, Bonlse FIM: A concentrically and radially adjustable holder for ten microelectrodes. Plluegers Arah 346: $1,67-170,1974$

13. Weidmann S: The effect of the cardiac membrane potential on the rapid awatability of the sodium carrying system. I Physiol (Lond) 127: $21^{\alpha}$. 224,1955

14. Ninomiya II: Direct evidence of nonuniform distribution of wagal effects on dog atria. Circ Res 19:576-583,1966

15. Mines $\mathrm{OR}$ : On dynamic equilibritum in the heart. J Physiol (Lond) 46: $350-383,1913$

16. Moe GK: On the muliple wavelet hypothesis of atrial fibriflation. Arch Internait Pharmencodyn The $140: 183 \cdots 188,1962$

17. Moe: CoK, Rheinboldi WC, Abilskow JA: A computer model we atrial ribrillation. Am fifeart $167 ; 200-220,1054$

18. Mos GK: Evidence for re-entry as a mechnnism ol cardiac arrhythmias. Rev Physiol Hochem phamacol 72, 55-81, 1975

19. Watanabe Y, Dreif L LS. Newer concepts in the genesis of cardinc arthythmias. Amer Hearti J 76:114\%135, 1968

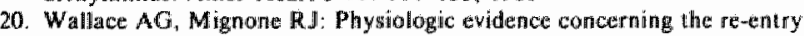
hypothesis for ectopic beats. Am Meart J 72; 60-70, 1966

21. Watanabe $Y$, Dreifus L.S: Mechamism of ventricular fibrillation. Jap Heart 7 : 110-120, 1966

22. Cramefield PF, Hoffman BF: Conduction of the cardiac impulse, Ill. Summation and inhibition. Circ Res 28: $220 \cdots 223$ " 1971 


\section{Chapler :}

THE "LEADING CIRCLE" CONCEPT:

A NEW MODEL OF CIRCUS MOVEMENT IN CARDIAC

TISSUE WITHOUT THE INVOLVEMENT OF AN ANATOMICAL OBSTACLE 


\section{SUMMARY}

In small pieces of atrial myocardium of the rabbit, sustained periods of circus movement tachycardia were produced by the induction of a single properly tined premature beat. With multipie intracellular and extracellular electrodes the spread of activation duxing the tachycardia could be analyzed accurately. Because in the present experiments there was no gross anatomic obstacle for the impulse to circulate around, special attention was paid to the phenomena occur$x$ ing in the centre of the circus movement. It was found that in the absence of an inexcitable central cbstacle the centre of a circus movement was invaded by multiple centripetal wavelets which converged in the very centre of the circuit. on basis of these observations a new model of circulatina excitation in cardiac tissue was developed. The properties of this model (referred to as the leading circte concept) were compared with the behaviour of circus movement around an anatomic obstacle. It turned out that both types of circus movement tachycardia responded differently to changes in basic electrophysiologic properties as conduction velocity and refractory period. So the administration of Carbamylcholine to the tissue bath caused a marked acceleration of the leading circle tachycardia, whereas circus movement in a ring of atrial tissue was hardly affected. On the other hand, depression of conduction velocity by application of moderate doses of Trx. Mad a more pronounced effect on circus movement in the ring preparations comparea to tachycardias based on a leading circle mechanism. Finally it is suggested to use the strength-interval curve - aftex some modification - to describe and predict the behaviour of a leading circle tachycardia. 
INTRODUCTION

In the foregoing parts of our series of papers on circus movement in rabbit atrial muscle $(1,2)$, we were able to show that in a small piece of atrial myocardium the induction of a properly timed premature beat can force the impulse in a circuitous route, thus setting the stage for a period of tachycardia. Evidence was gathered that the naturaily existing non-uniform recovery of excitability in the atrium was of major importance for the occumrence of unidirectional block of the premature impulse, which, of course, is a prerequisite for the onset of circus movement. Furthermore, with a technique of synchxonous mutiple microelectrode recording detailed information was obtained about the cellular responses during the initiation of the cixcus movement (2). However, thus far, no conclusive model of circus movement in the absence of an anatomic obstacle could be derived. This was mainly caused by lack of information about what is happening in the centre of a cixculating impulse. In most studies on circus movement and re-entry, the model as introduced by Mines in 1913 has been used (3). This model is based on observations in ring-shaped strips of cardiac tissue and implicitely supposes the presence of some kind of gross anatomic obstacle. However, in many cases of tachycardia, like in our experimental stuales, circus movement without the involvement of a central obstacle sems likely. Therefore, we do not consider the model of Mines suited to describe such a type of circus movement tachycardia.

In this paper we now report the results of multiple microelectrode recordings from the centre of sustained circus movement in small segments of isolated rabbit atrium. From these complementary studies a new model of circus movement could be derived which is applicable to circulating excitation in the absence of a non-excitable central obstacle. This model, which we called the "leading circle" concept, differs in various respects from the conventional model of circus movement. Both models respond differently to changes in basic electrophysiologic conditions like the steepness of phase zero of the action potential, the conduction velocity of the impulse and the effective and relative refractory periods. Also the mechanism of interruption of the circulating excitation may differ in both types of circus movement. 


\section{METHODS}

Preparation, perfusion syster, stimulating and recording techniques and the. method of data processing were the same as described previously $(1,2)$. The isolated left atrium of the rabbit was regularly paced with an interval of 500 msec. Tachycardias were produced experimentally by the induction of a single properly timed premature stimulus (duration $1 \mathrm{msec}$, intensity four times diastolic threshold). The spread of activation through the preparation was measured either with 10 unipolar surface electrodes or with a multiple microelectrode technique (4). To study the course of the excitation during tachycardia with a limited number of recording leads, several precautions have to be taken. One possible approach, which we used so far, is to induce tachycardias in a reproducible way. If the subsequent periods of tachycardia are identical, the course of the excitation wave can be mapped out, combining the results obtained during separate tachycardias. However, since slight differences in the time course of the tachycardias are accumulating, in most cases the requirement of identity was fulfilled only during the first beats. In a later stage of the arrhythmia it was hazardous to relate time measurements obtained from different episodes of tachycardia. To map the excitation process, then another procedure should be followed. The complete mapping must be accomplished during the progress of one sindle sustained tachycardia. Furthermore, during the mapping procedure the rate and rhythm of the tachycardia must stay constant and the mechanism underlying the arrhythmia should not change. Undex nomal conditions, generally the induction of a premature beat resulted only in short runs of rapid repetitive activity. However, the addition of Carbanylcholine to the tissue bath $\left(10^{-6}-10^{-7} \mathrm{~g} / \mathrm{ml}\right)$, which shortened the refractory period up to about $40-50 \mathrm{msec}$, turned out to be an appropriate method, not only" to facilitate the induction, but also to favour continuation of the tachycardia. Under these conditions we could frequently produce tachycardias which sustained for more than 30 minutes; during that time rate and rhythm of the tachycardia varied only in trifling degree. This period was sufficient to map the spread of activation either with 10 extracellular or with 10 intracellular electrodes. Successive registrations were time aligned relating the measurements to one or more fixed extracellular reference leads. This procedure did not only result in an accurate measurement of the excitation pattern during sustained tachycardia, but also allowed to make intracellular recordings from the centre of the circus movement. 
RESULS

Intracellular recardings from the centre of cixcus movement

Figures 1 and 2 show the results of an experiment in whicl the excitation process during sustained tachycardia was mapped with the multiple microelectrode technique. Similar results were obtained in two other experimerts. in this case it was very aifficult to evoke tachyarrhythmis under normal conditions only one area could be found where a premature stimulus (coupling interval 70 msec) resulted in just one extra non-stimulated beat. After adation of Carbamylcholine $\left(3 \times 10^{-7} \mathrm{~g} / \mathrm{ml}\right)$ the refractory period decreased to about $40 \mathrm{msec}$. single earIy premature stimuli now easily induced tachycardias which had a great tendency to continue. Not only the moment of the test stimulus, but also its polnt of application was now much less critical. This marked effect of Carbamyloholine was generally observed. The map at the right side of figure 1 clearly shows that the tachycardia was based on circus movement of the impulse through the myocaraium. This activation pattern resulted from the time measurements of action potentials of 94 different fibers.
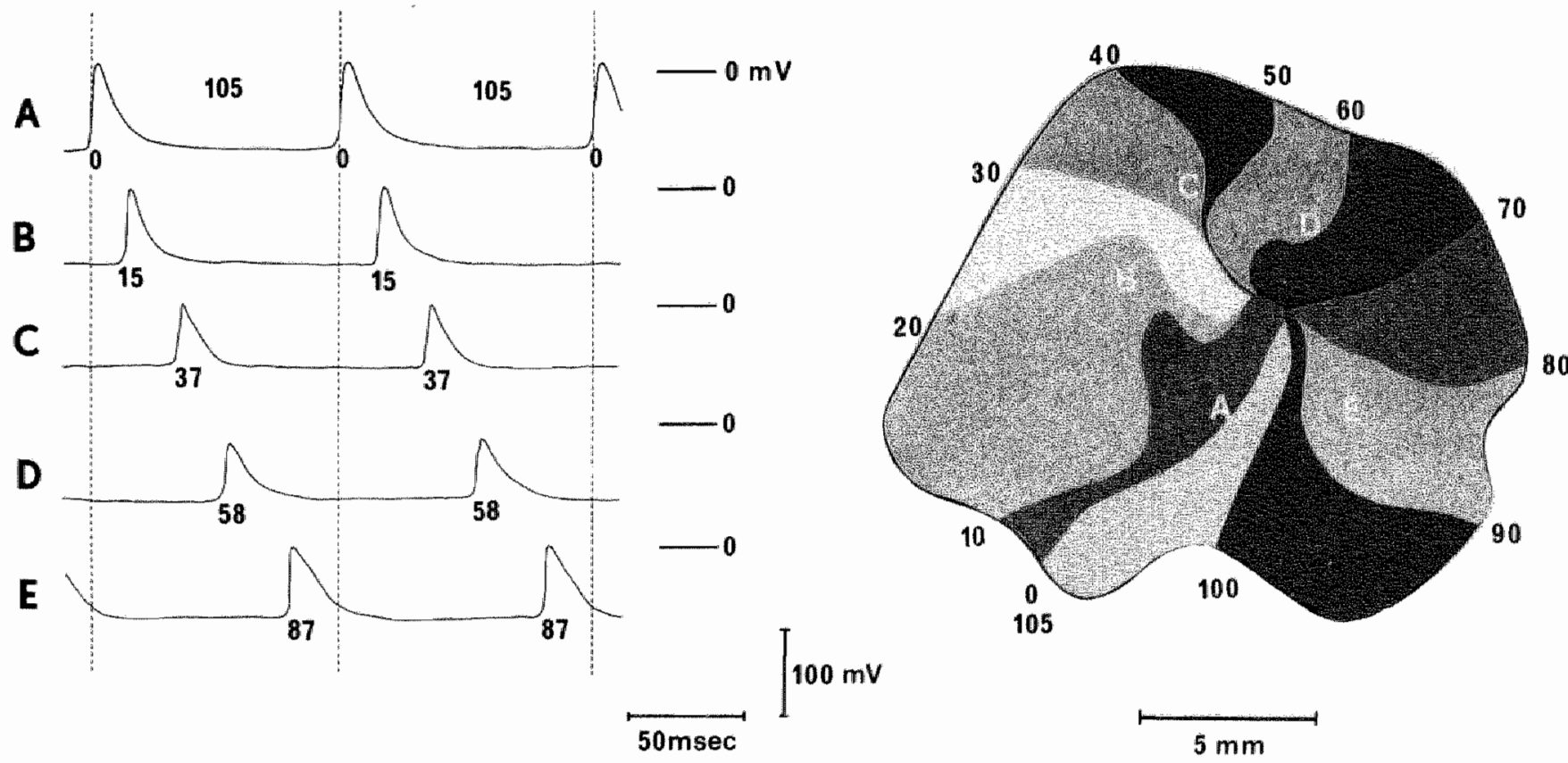

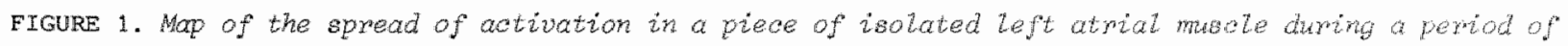

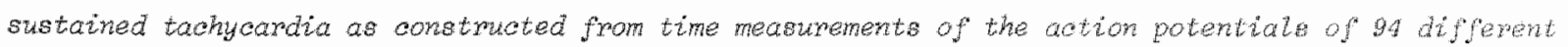
fibers. The impulse is contimousty rotating in a chockive dixedion with a revotution the of ros mea.

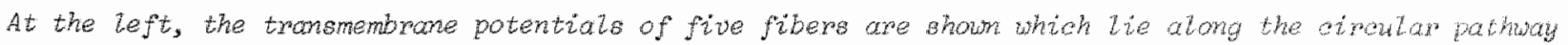

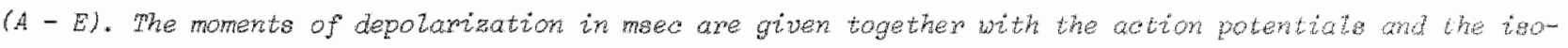
chronic tines of the map. 
Al1 these intracellular recordings were made within a period of $24 \mathrm{~min}$, auring which the tachycardia showed only minimal variations in cycle length 1105 msec, t 5 msec). At the left of the map the transmembrane potentials of 5 fibers $(A-E)$, lying along the circular route, are given. The action potentials are of markediy short duration which is caused by the influence of Carbamylcholine. It should be emphasized, however, that although the effective xefractory period was shortened also by the administration of Carbamylcholine, the effect on the action potential duration was stronger than the effect on the refractory period. Therefore, under the influence of Carbamylcholine the effective refractory pexiod outlasted the duration of the action potential, i.e., some time after full repolarization the fibers were still inexcitable.

Figure 2 shows the intracellular recordings of seven fibers located on a straight line through the centre of the clrcus movement. The most peripheral fibers (A and D) are the same as in figure 1. The fibers in the centre are marked by digits (1-5). As can be read from the time measurements of these fibers, the central area of the circuit was activated in a centripetal direction. From fiber A the impulse excited fibers $1,2,3$ and 4 in that order. When penetrating deeper into the centre of the vortex, the centripetal wavelet los.t more and more of its "stimulating efficacy" until it was unable to excite the tissue ahead. Going from Fiber 1 to 4, amplitude, rate of rise and duration of the responses are all gradually decreasing, finaliy resulting in complete extinction of the impulse somewhere between fibers 4 and 5 . At the opposite side of the circuit essentially the same sequence of events takes place. There, half a revolution time later, the circulating impulse is penetrating the centre again, traveliing from fiber $D$ to the ribers 5, 4 and 3 . Again the centripetal wavelet is conducted with decrement, resulting in extinction of the impulse between fibers 3 and 2 . As a result of this course of events, fibers 3 and 4, which were located in the very centre of the circus movement, only showed local responses. Because this area was invaded twice during each revolution of the impulse, the frequency of these local responses was double the rate of the tachycardia.

In a previous paper (1) we speculated about the mechanism which might explain why duxing tachycardia the fibers in the centre of the circus movement are not activated while during regular driving of the preparation the same fibers show a normal response: "A possible explanation is that the membrane potential of these fibers is held above threshold by the electrotonic influence of the depola- 

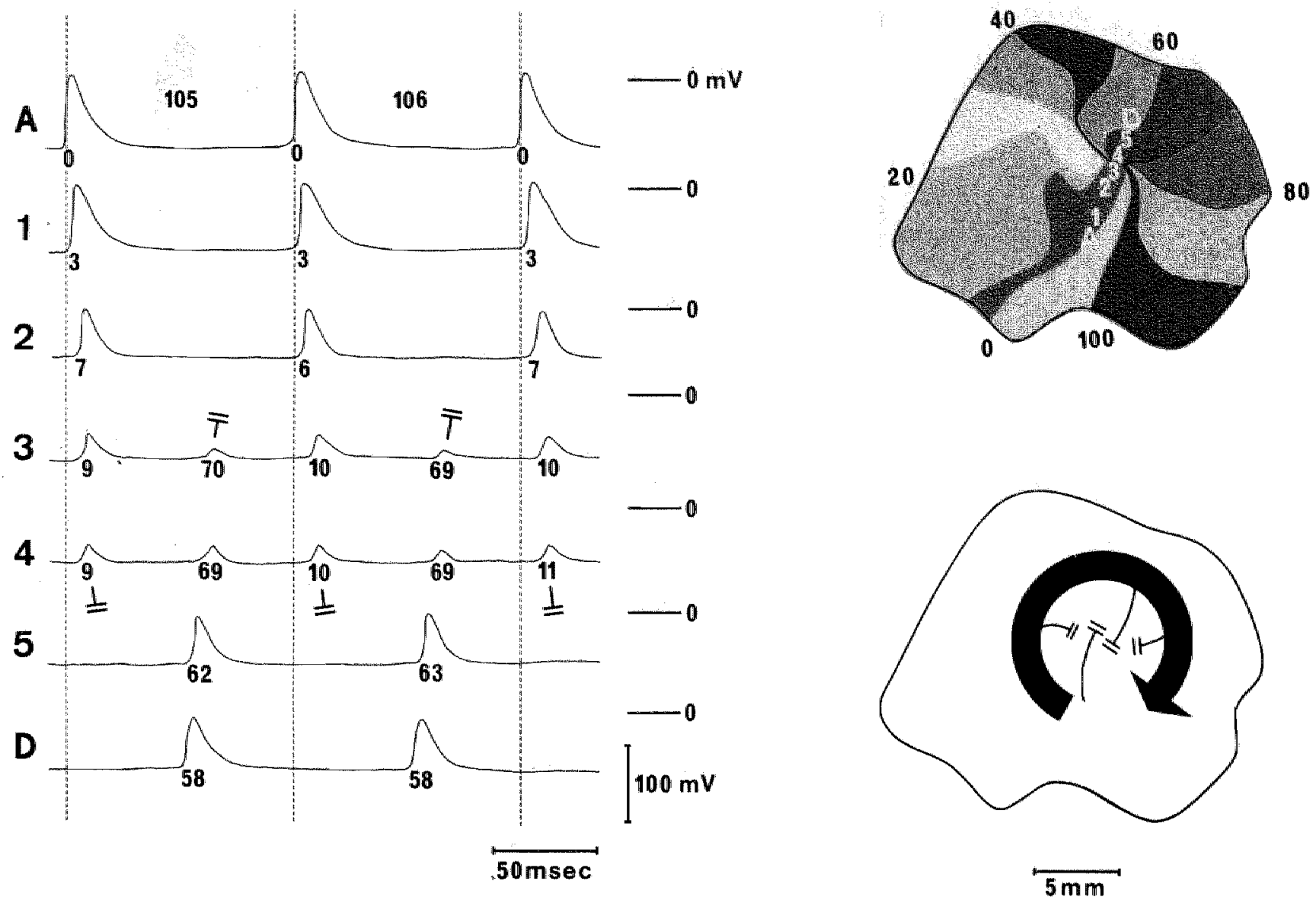

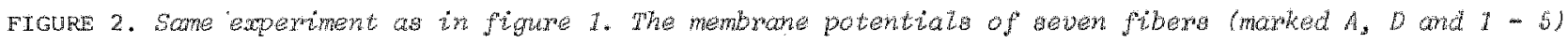

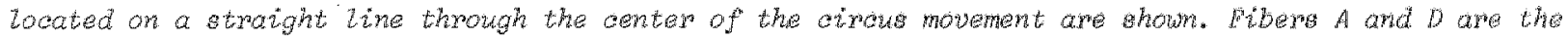

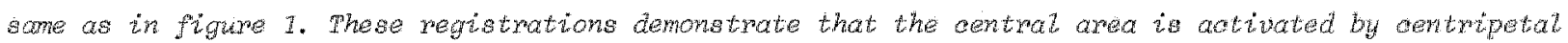

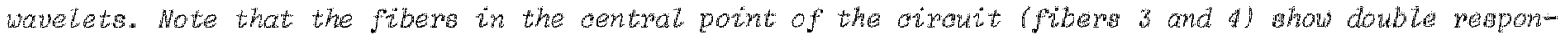
ses of subnornat amplitude. Both responses are whable to propagate beyond the center" thus preventing the

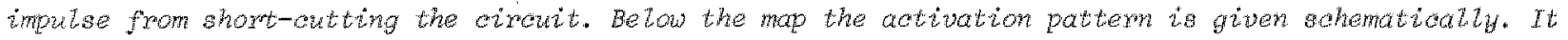
shows the leadirg arrot with the comerging wovetets in the center. Btock te indiated by dowble bars.

rization front which continuously turns around this area. In this way the centre functionally is inexcitable, and the activation wave will travel around this functional obstacle" (1): The intracellular recordings from the centre of sustained circus movement, presented here, show that this speculation is false. The membrane resting potential of fibers 3 and 4 does not show such a degree of depolarization that they can be expected to be inexcitable. On the contrary, the centre of the vortex is continuously invaded by multiple centripetal wavelets which are blocked in the very centre of the circuit. Here the impulse encounters 

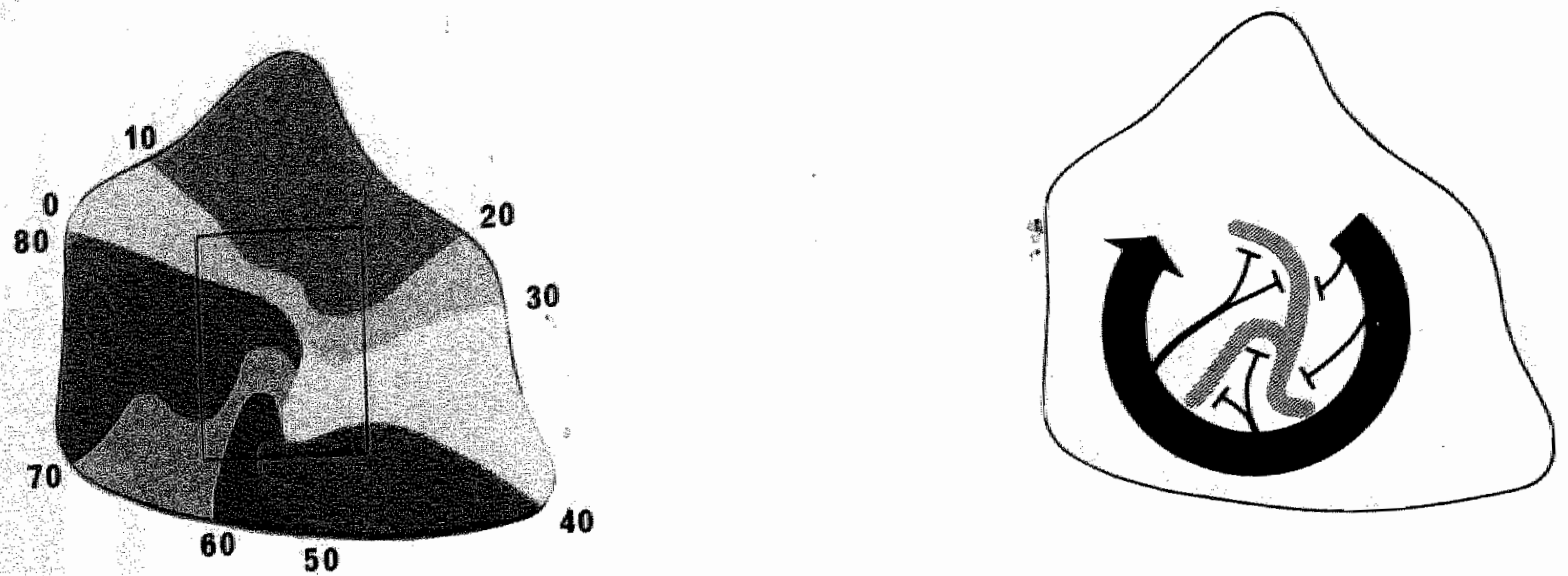

\section{$5 \mathrm{~mm}$}

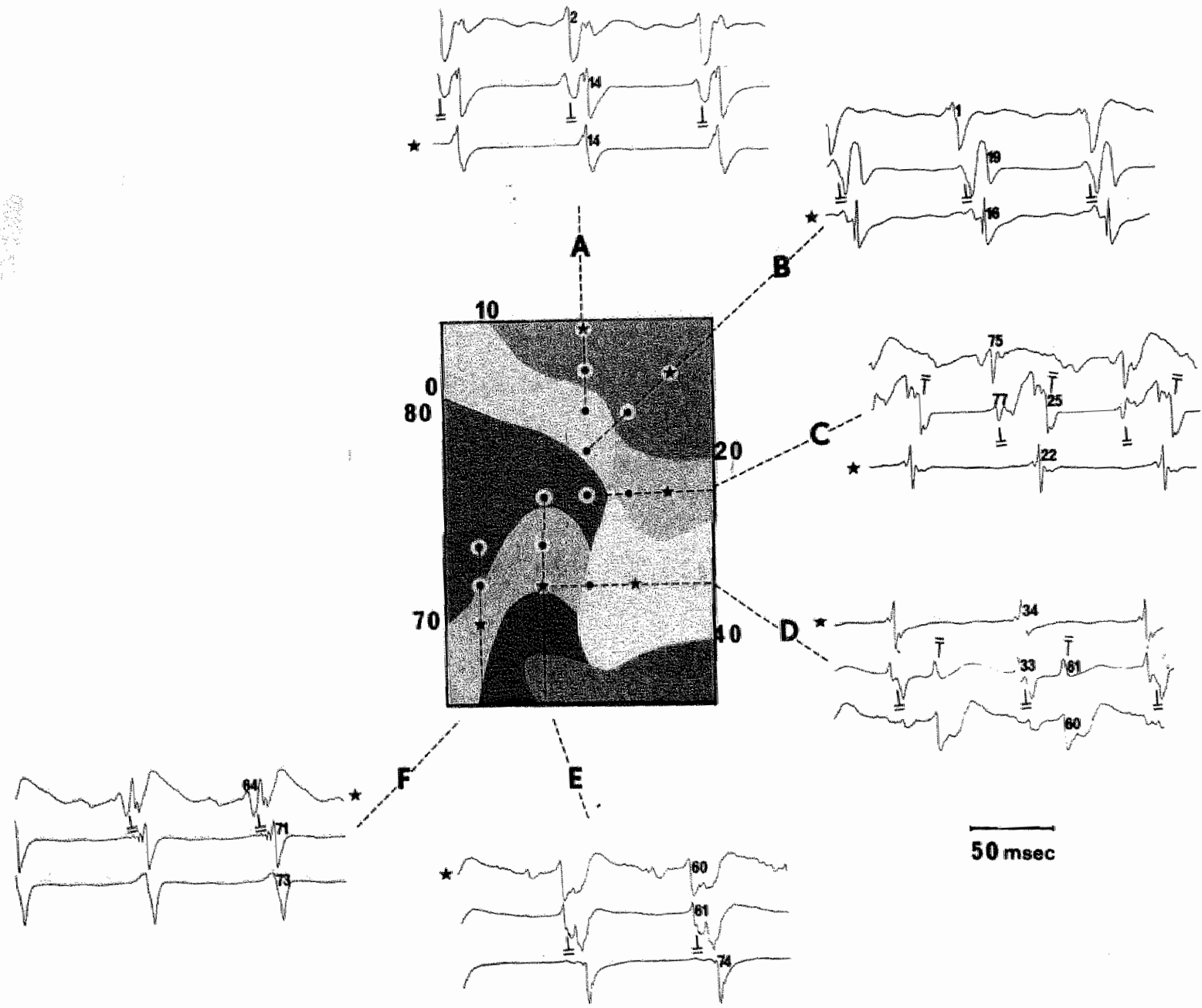

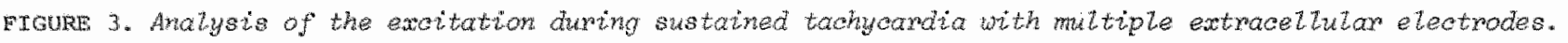
At the top the mop of the apread of activation is given together art a schematic respresentation. In the latter the dimenstons of the leading chowt and the centripetal wavetets are given. The hatched area in the soheme irdiontes the area whare the centripetal wavelets are blocket. In the lower parti of the figure the central part of the map is eniarged and given together wh groups of three unipolar electrograns (A F) recorded from that area. The sites of reaonding axe indiated on the mop, the most peripherat ragistrations being manked by asterisks. In the grompe of eloctrongams the oorresponding biocks ane indicated by dow le baxs. See text for further explanation. 
fibers which are still in their refractory phase since they were already activated by another centripetal wavelet just half a revolution time earlier. In this way the circulating impulse is prevented from shortcutting the circuit, whereas the area of converging wavelets serves as an "obstacle" for the impulse to turn around. In the diagram beneath the map in figure 2 the sequence of excitation is sumarized schematically. It can be described as a "leading" circulating wave front, which not only activates the periphery but from which also centripetal wavelets are emerging which collide in the centre of the circuit. In this experiment the diametex of the leading circle was about $6 \mathrm{~mm}$. Hence the total length of the circular pathway can be estimated to be about $20 \mathrm{~mm}$.

Extracellular recordings from the centre of circus movement

Although the technique of multiple microelectrode recording allows detajled analysis of the electrical behaviour of different individual fibers in a wide range of experimental circumstances, its use is limited because of the delicacy of the technique. Since measurement of the course of excitation through caxdiac muscle with extracellular leads is much more simple and because surface electrodes have a much wider field of application, we also exanined whether the mechanisin in the centre of circus movement could be studied with this method. Figure 3 shows the results of an experiment in which the spread of excitation during a sutained tachycardia was mapped with multiple extracellular leads. In this experiment again Carbamylcholine $\left(2 \times 10^{-7} \mathrm{~g} / \mathrm{ml}\right)$ was added to the tissue bath to facilltate the induction and to favour the perpetuation of tachycardias. The map reveals that during tachycardia the impulse was rotating lin a clockwise direction with a revolution time of $80 \mathrm{msec}$. At the bottom of the figure the central part of the map is enlarged and is given together with a number of electrograms recorded fxom this area. Accurate analysis of these electrograms again denonstrates the existence of multiple centripetal wavelets converging into the centre of the circuit. In this case, howevex, rather than that the wavelets collided at one single point, there was a longdrawn area where the centripetal impulses were blocked. In the diagram in the right uppex corner of the figure the spread of excitation in the cen tral area is given schematically as it can be recognized from the multiple electrograms. The area of block is indicated by hatching. In the tracings the corresponding blocks are indicated by double bars. In all panels the tracings indicated by 
an asterisk is recorded at the most pexipheral site. (Note that the lower trace of panel D is the same as the upper trace of panel E.) As in case of intracellular recording (see figuxe 2), in the area of collision the electrograms show two clearIy separated responses. For instance, in panel $C$, the upper trace (recorded from the left site) shows an activation $75 \mathrm{msec}$ after the zero reference. The lower trace (right site) shows a single response at $22 \mathrm{msec}$. Since the cycle length of the olrcus movement was 80 msec this means a time lapse of 27 msec between the activation of the two closely approximated sites. The midale trace of panel $\mathrm{C}$ shows that this delay is not caused by slow conduction, but by a conduction block between the two sites. During each cycle of the cixcus movement the middle trace shows two distinct complexes. The first, belng of low amplitude ( $t=77$ msec), is almost simultaneous with the deflection in the upper trace. The second complex ( $t=25 \mathrm{msec}$ ) is linked with the lower recording. Thus, each of the two complexes of the middle trace belongs to an other centripetal wavelet coming from opposite directions and colliding at the midale one of the three recorded sites. The same can be seen in panel $D$. In the other panels block of centripetal wavelets can also be recognized. There, however, the double complexes in the middle traces are less clearly separated because the detour of the impulse around the site of block is relatively small. Thus also with extracellular recordings one can get the necessary information to identify this type of circus movement.

The effect of Carbamylcholine, Tetrodotoxin and Temperature on circus movement tachycardia

To lucidate whether the above described type of circus movement responds differentily to changes in electropiysiologio propexties compared to circus movement around an anatomical obstacle, we studied the effect of Carbamylcholine, Tetrodotoxin (TWX) and temperature on the rate of both types of tachycardia. In these experiments the left atria of two rabbits were isolated and put together in the same tissue bath. One prepaxation was keot intact while the other was transformed into a ring-like structure by making multiple incisions as indicated in fioure 4. Cutting the preparation in this way, the lenrth of the ring was about $40 \mathrm{~mm}$. With the single stimulus method sustained circus movement was then induced in either preparation. Generally in ring preparations tachycardia could be induced more easiIy than in the intact segments of the atrium; the tachycardias in the ring also 
tended to last longer. Multiple extraceliniar recordings confirmed that the tachycardia was based on a circuitous secuence of excitation through the ring. Like in the intact preparation also in the ring preparations the site of application of the test stimulus was important, but in most preparations it was not too difficult to find an area where the test stimulus started tachycardia. The rate of tachycardia in the ring was always lower than the one in the intact sec. ment of the atrium. After revolution time of both independent circulatina excitationshad become constant, Carbamylcholine or TTX was added to the tissue bath and the effect on cycle length of the two tachycardias was recorded.

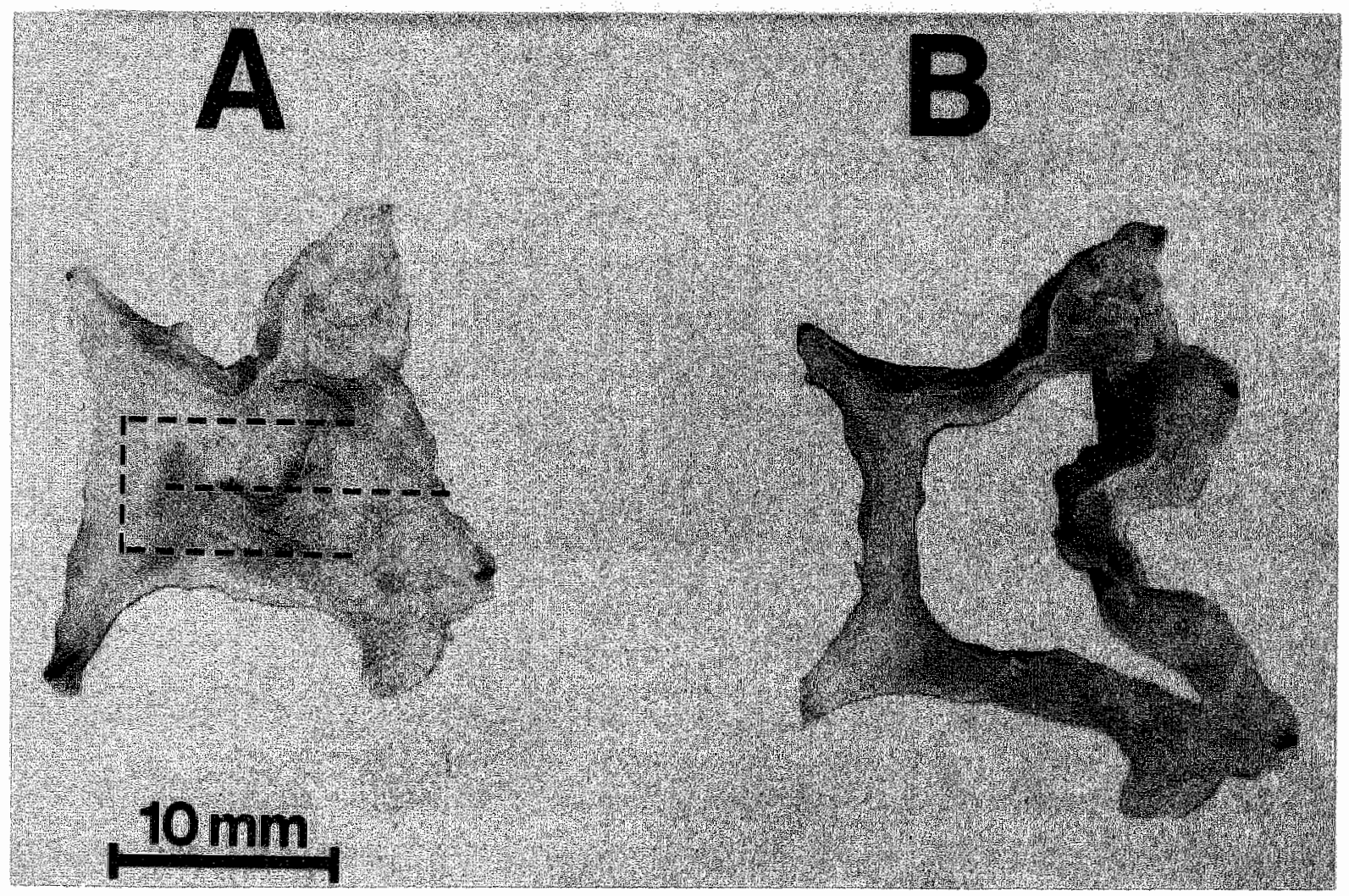

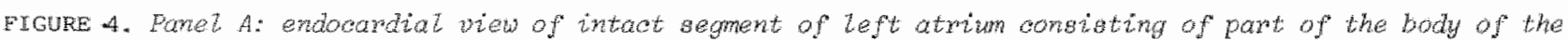

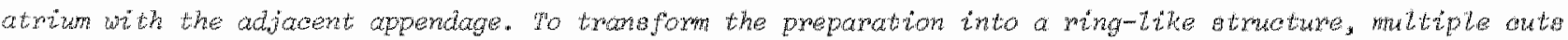
were made as thdicated by the dotted tines. Pane $B$; ring preparation of atrial maste as it results from the multiple incisions.

Eigure 5 shows the effect of Carbamylcholine $\left(2 \times 10^{-6} \mathrm{~g} / \mathrm{ml}\right)$. The example $1 \mathrm{~s} x \mathrm{x}-$ presentative for four experiments. The concentration of carbamylcholine used cau ed a shortening of the effective refractory period up to about 40 - 50 msec; cor duction velocity increased only slightly. As a control, the interval of a sponti neously beating isolated riaht atrium was also recorded. Prior to the administration of Carbamylcholine the interval of sinus rhythm was 365 msec. 

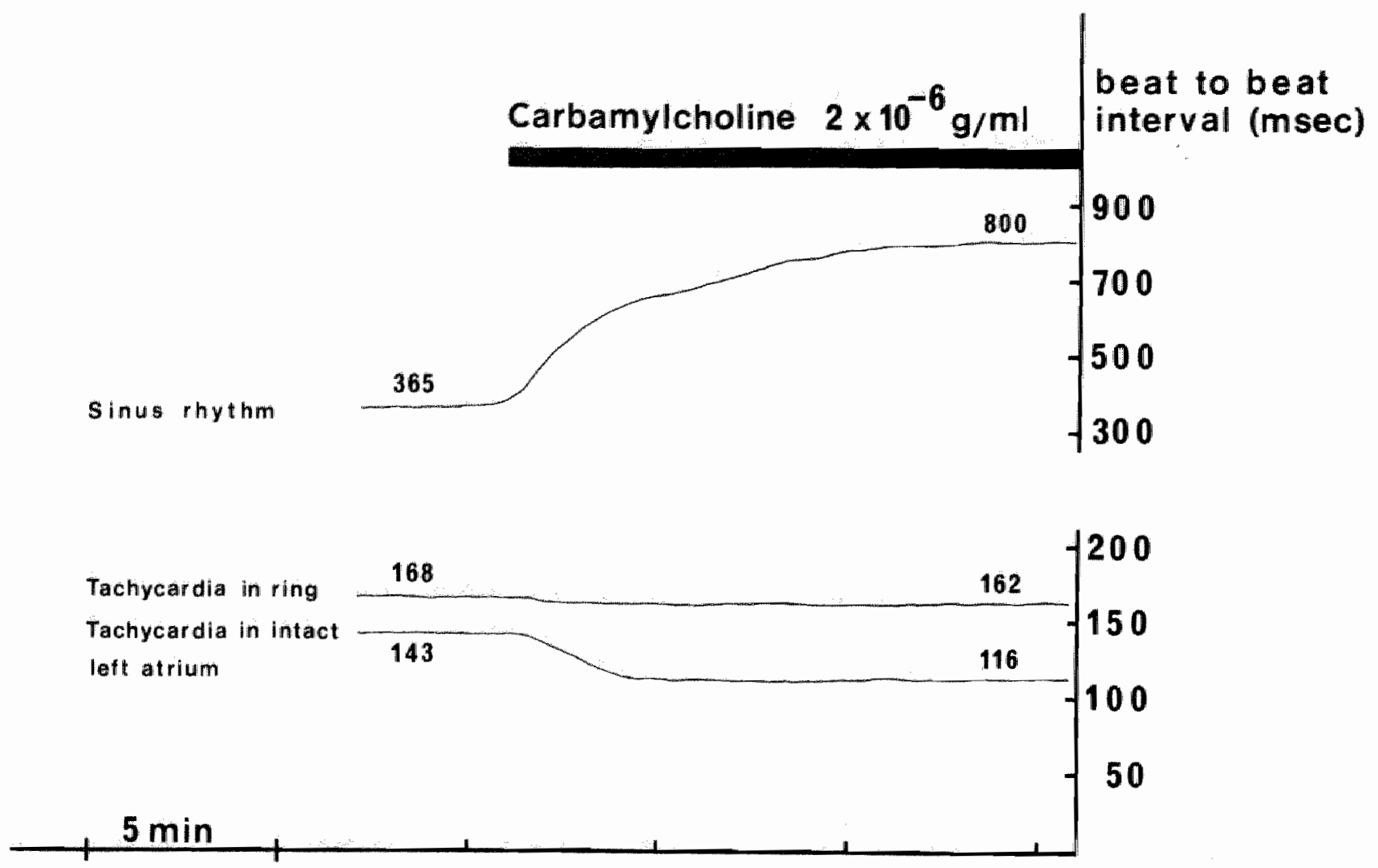

\section{Time}

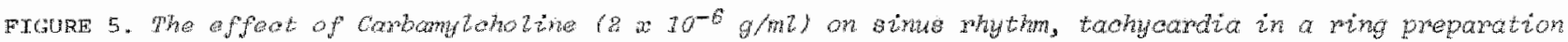

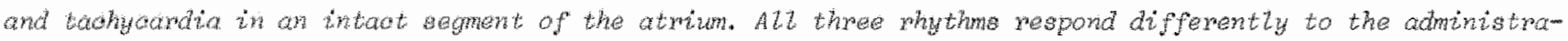

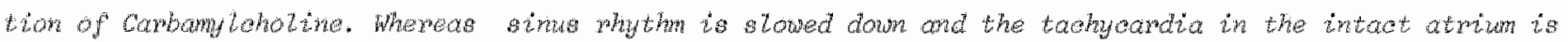

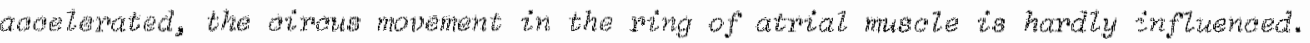

The revolution time of the impulse through the ring of atrial muscle amounted to 168 msec, whereas the cycle length of the tachycardia in the intact preparation was $143 \mathrm{msec}$. All three rhythms responded differently to the action of Carbamylcholine. As expected, sinus rhythm slowed down, and the beat to beat interval of the isollated right atrium increased from 365 to $800 \mathrm{msec}$. In contrast the circus movement in the ring of atrial muscle was hardly affected. Carbamylcholine only caused a slight shortening of the cycle length from 168 to $162 \mathrm{msec}$ which can adequately be explained by the minute increase in conduction velocity brought about by the drug. The tachycardia in the intact piece of atrial muscle, however, showed a marked acceleration, the circulation time beino substantially reduced from 143 to 116 msec. Frequently the application of Carbamylcholine caused a sudden 
termination of the tachycardia in the intact preparation; in the ring-ijke preparations this was never bbserved. This maxked difference in the effects of carbamylcholine on the two different atrial preparations strongly points to the existence of two different types of circus movement tachycardia (see Discussion).

Three experiments were done to study the effect of Tix on circus movement with and without an anatomic obstacle. Figure 6 shows an example. Tux was administered in such low doses $\left(3 \times 10^{-7} \mathrm{~g} / \mathrm{ml}\right)$ that impulse conduction was slowed down but not completely blocked. Measurement of strength-interval curves before and during the administration of TTX made clear that in these doses TrX did not affect the time course of the restoration of excitability. In both models of circus movement the decrease in stimulating efficacy and conduction velocity of the impulse induced by TTX resulted in a deceleration of the tachycardia. However, the effect was more pronounced in the ring preparation than it was in the intact segment of the atrium. In this example the revolution time of the circulating excitation in the ring preparation increased from 138 to $172 \mathrm{msec}$ (25:), while in the intact piece of atrial muscle revolution time increased from $117 \cdot$ to $129 \mathrm{msec}$ (11\%). This difference in behaviour again suggests a different underlying mechanism.
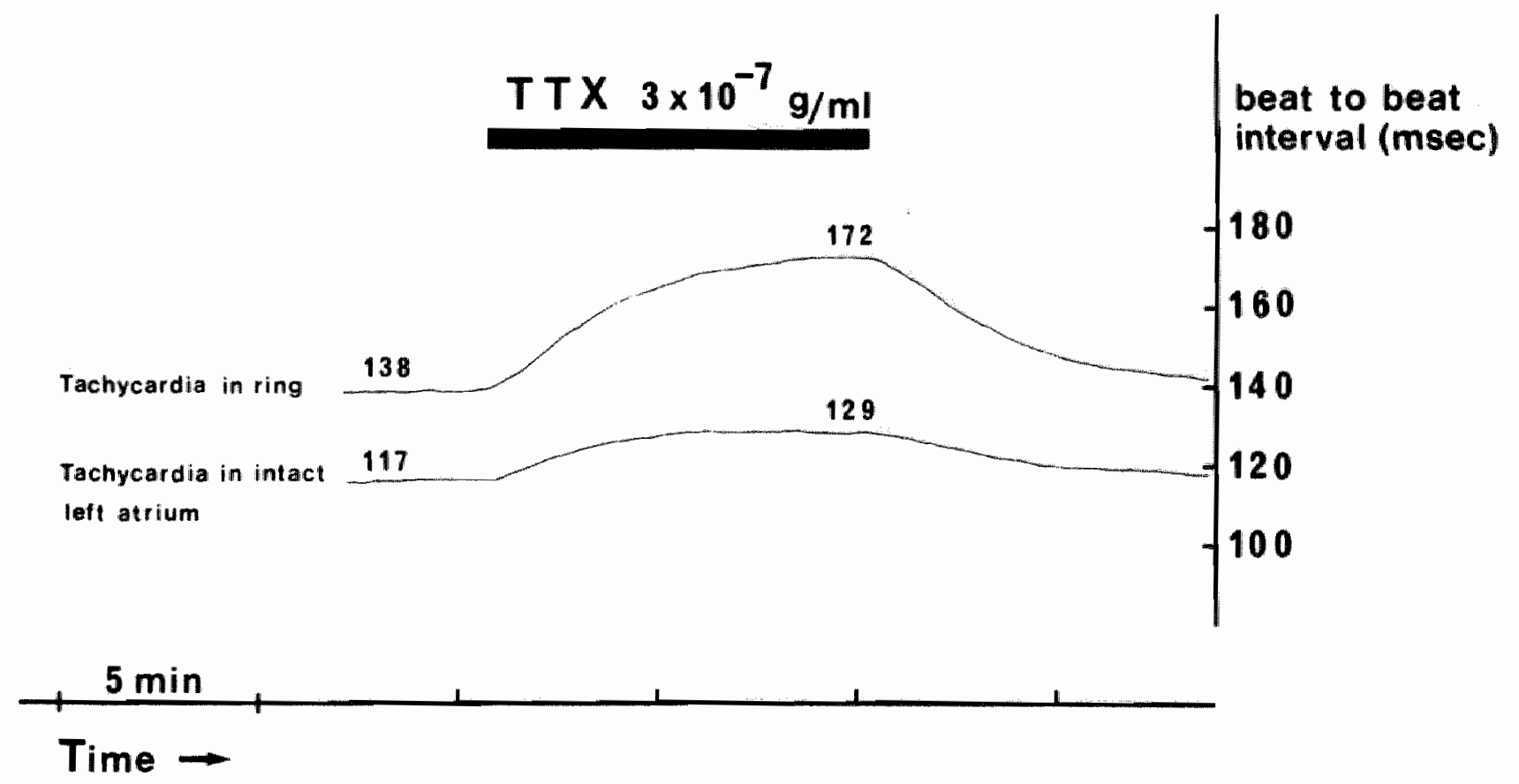

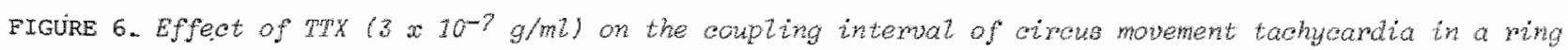

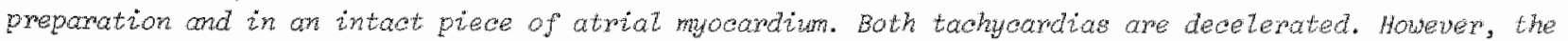
effect is more prowowned in the wing preparation than in the intat atrim. 
The effects of temperature on circus movement tachycardia was studied in three cases. It is known that cooling of the heart causes a decrease in the rate of depolarization, whereas the duration of the action potential is markedly prolonged $(5,6)$. Conseguently conduction velocity is depressed and the refractory period is lengthened. These changes in electrophysiologic properties resulted in a marked diminution of the rate of the tachycardia. Figure 7 gives the temperature dependency of circus movement in a ring-like structure and in an intact piece of myocardium. At $370^{\circ}$ revolution time was 172 and $134 \mathrm{msec}$ respectively. Lowering the temperature resulted in a gradual lengthening of the beat to beat interval. At $29^{\circ} \mathrm{C}$ the cycle length of the tachycardia in the ring of atrial tissue had increased from 172 to 288 msec $(67 \%)$ whereas the interval in the intact preparation had become 215 msec (60) increase). Thus, although in both models the effect on the circulation time was considerable, no clear difference in their response to temperature changes could be observed.

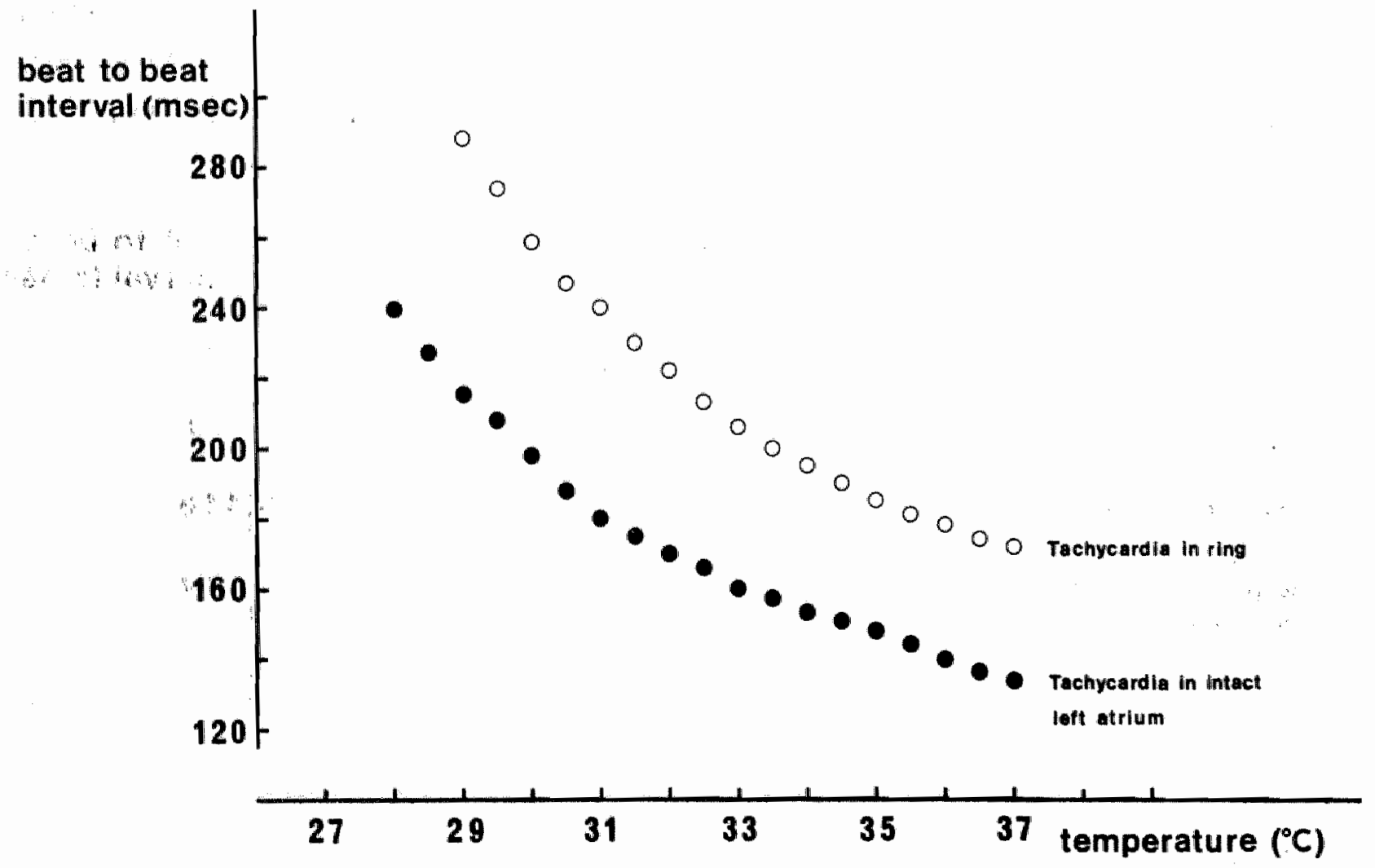

FIGURE 7 . The effect of temperature on tachycardia in a wing of atwial macte compared with the effect on atras movement in an intat atriat segrient. In both cases, Lowering of temperature caused a marked prolongution of the revolution time of the inpulse. 
DISCUSSLW.

The leading circle concept

From the results described above, a new model of circus movement in cardiac tissue emerges. When there is no anatomic obstacle which defines the length of a circular pathway, the circuit in which the impulse circulates is completely defined by the electrophysiologic properties of the fibers composing the circuit.

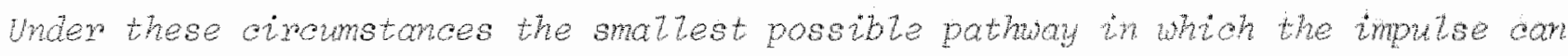
continue to ciratate, is the cimout in which the stimitating efficaly of the circulating wave pront is jist enough to excite the tissue wheat which is stint in its relative refractory phase. In other words, in this smallest circuit possible, which we designated as the "leading circle", the head of the circulating wave front is continuously biting in its own tall of refractoriness. Because of this tight fit, the length of the circular pathway equals the "wave length" of the circulating impulse (i.e. product of conduction velocity and refractory period). Tn the centre of the leading circle, dimensions are too small for a sustained circus movement. Within this area a circulating impulse would encounter tissue where excitability has not yet recovered sufficiently. As a conseguence, the conduction velocity of the impulse would be secondarily depressed below some minimal. value where successful. impulse propagation is no longer possible. In fact, the area within the leading circle 1 s activated by centripetal wavelets that arise from the leading circle and collide in the very centre of the clrcus movement. Going from the leading cixcuit to the periphery, the length of a circular pathwy is getting longer and longer. Since a longer pathwy indicates a Ionger revolution time, it is evident that also the fibers in the periphery wil be excited by wave fronts emerging from the leading circle, rather than that they form part of a longer circuit. In figure 8 the leading circle concept is compared with the model of circus movement around an obstacle as proposed by Mines (3). The matn features of the leading circie model are: 1) The length of the circuit is not determined by anatomic but by electrophysiologic properties. 2) The dimensions of the circuit are not fixed but may change with alterations in electrophysiologic properties, such as conduction velocity, upstroke of the action potential, and time course of recovery of excitability. 3) Because there is a tight fit bew 
tween the crest and the tall of the impulse there is no excitable gap in the cjrcult. This implicates that a wave Eront (or stimulus) of greater efficacy than the circulating impulse is required to intexfere with the leading circle. This may have some limportant implications for the degree of protection of such a focus of reentrant activity. 4) Because the centre of the circuit consists of excitable tissue, under some circumstances the impulse may succeed to cross the centre. In comparison with the Mines model such a short-circuit offers an additional mechanism for the interruption of tachycaraia. 5) Whereas the revolution time of a circus movement in a large anatomically defined circuit is inversely related to the conduction velodity of the impulse, in the leading circle model revolution time is primarily proportional to the time course of recovery of excitability of the fibers composing the circuit (see below).

\section{Circus movement around anatomic} OBSTACLE (MINES 1913)

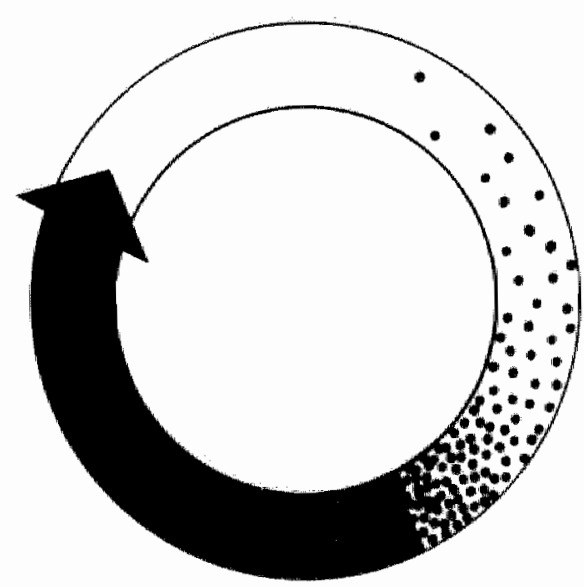

1. Length of circular pathway determined by perimeter of anatomic obstacle.

2. Length of circular pathway fixed.

3. Excitable gap between crest and tail of the impulse (white part of circuit).

4. Impulse can not shortcut the circuit.

5. Revolution time inversely related to conduction velocity.
Circus movement without anatomic obstacle (LEADING CIRCLE MODEL)

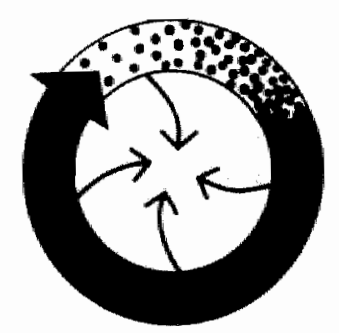

1. Length of circuit determined by conduction velocity, stimulating efficacy, and refractory period.

2. Length of the circuit can change with alterations in electrophysiologic properties.

3. No gap of full excitability.

4. Shortcut of the circuit possible.

5. Revolution time proportional to refractory period. 
Theoretical considerations on the leading circle model

As indicated by Lewis (7), three factors must be considered in any theory of circus movement, namely the length of the conduction pathway (P), the conduction velocity (V), and the duration of the refractory period ( $R$ ). Accoraing to this theory, a circulating excitation can only take place when the path length eguals or exceeds the product of conduction velocity and refractory period ( $\mathrm{P}$ VR). When in case of circus movement within an anatomically defined loop of excitable tissue the wave length of the impulse (VR) is shorter than the length of the circuit (P), there is a gap of full excitability between the crest and the tail of the circulating impulse. In this situation conduction velocity is not influenced by changes in refractory period. Since revolution time $=\frac{p}{V}$, and the length of the pathway is fixed, in this type of circus movement revolution time varies inverse$1 y$ with conduction velocity (rev. time $r \frac{1}{v}$ ). However, in many cases the situation cannot be described adequately in this simple manner. When the revolution time of a circulating excitation is too short to allow full recovery of excitability of the fibers in the circuit the depolarization wave will travel through relatively refractory tissue and consequently the conduction velocity will be reduced. In this situation conduction velocity (V) and refractory period (R) are no longex independent variables but on the contrary they are inextricably dinsed (8).

In the leading circle concept the length of the circuit is varlable, being defined by and equal to the wave length of the cixculating impulse (P $=V R$ ). This means that the revolution time of the impulse is not deternined by the length of a given circuit but by the length of the circulating impulse itself. Since revolution time $=\frac{P}{V}$, and $P=V R$, in the leading circle model the revolution time is proportional to the refractory period (rev. time " $R$ ). In fact, however, the process of recovery of excitability is too complex to be described by just one single value of the duration of refractoriness. A moxe accurate way to express the time course of restoration of excitability is to measure the strength-interval curve. Such a curve depicts the minimal stimulus strength which is reguired to induce a propagated excitation at different moments of prenaturity, or, vice versa, it gives the refractory period for stimuli of different intensities. With some modification, this well-known and easily measurable electrophysiologic relationship gives a much better description of the properties of the leading circle than the oversimplified relation: revolution time $\sim \mathrm{R}$. In the pathway of the leading circle 
the situation is very similar to the situation described by the strength-interval curve. In elther case, the strength of the stimulus, respectively the stimulating efficacy of the circulating wave front, is just enough to initiate, respectively maintain propagation. Therefore on the oxdinate of the strength-interval curve we can replace stimulus-strength by stimulating efficacy of the circulating impulse. on the abscissa the interval then represents the interval of the tachycardia i..e. the revolution time of the circus movement (see fig. 9). This modified strengthinterval curve thus describes the main feature of the leading circle model, i.e. the existence of a tight fit between the head and the tail of the circulating impulse. In the pathway of the leading circle, under all circumstances, the relation between stimulating efficacy and revolution time of the impulse will fit the strength-interval curve. The area to the left of the curve refers to those circuits which, like the central. area of the leading circle, are too small to accommodate sustaired circus movement. The area to the right of the modified strengthinterval curve represents the situation that exists in the circuits which have a longex pathway than the leading circle.

Changes in rate of leading circle tachycardia by al terations in electrophysiologic properties

Figure 9 shows how the strength-interval curve can be used to predict changes in revolution time of a leading circle tachycardia in response to changes in some basio electrophysiologic properties. Panel A ilustrates the effect of a decrease in amplitude and rate of rise of the action potential (taken together as s.tilating efficacy). When during a certain tachycardia with a revolution time $a$, the stimulating efficacy of the circulating wave front is diminished, according to the modified strength-interval curve, the revolution time will increase from $a$ to $b$. The experimental imitation of this situation by the application of Trx indeed revealed. Such a decrease of the rate of the tachycardie (see fig. 6). In case of a shortening of the refractory period the strength-interval curve shifts to the left (broken line, panel B). Assuning that the stimulating efficacy of the circulating excitation keeps constant, the given shift of the strength-interval curve results in a shortening of the revolution time from $a$ to $b$. The observed acceleration of the leading circle tachycardia by the application of Carbamylcholine (see fig. 5) is in good agreement with this explanation. 

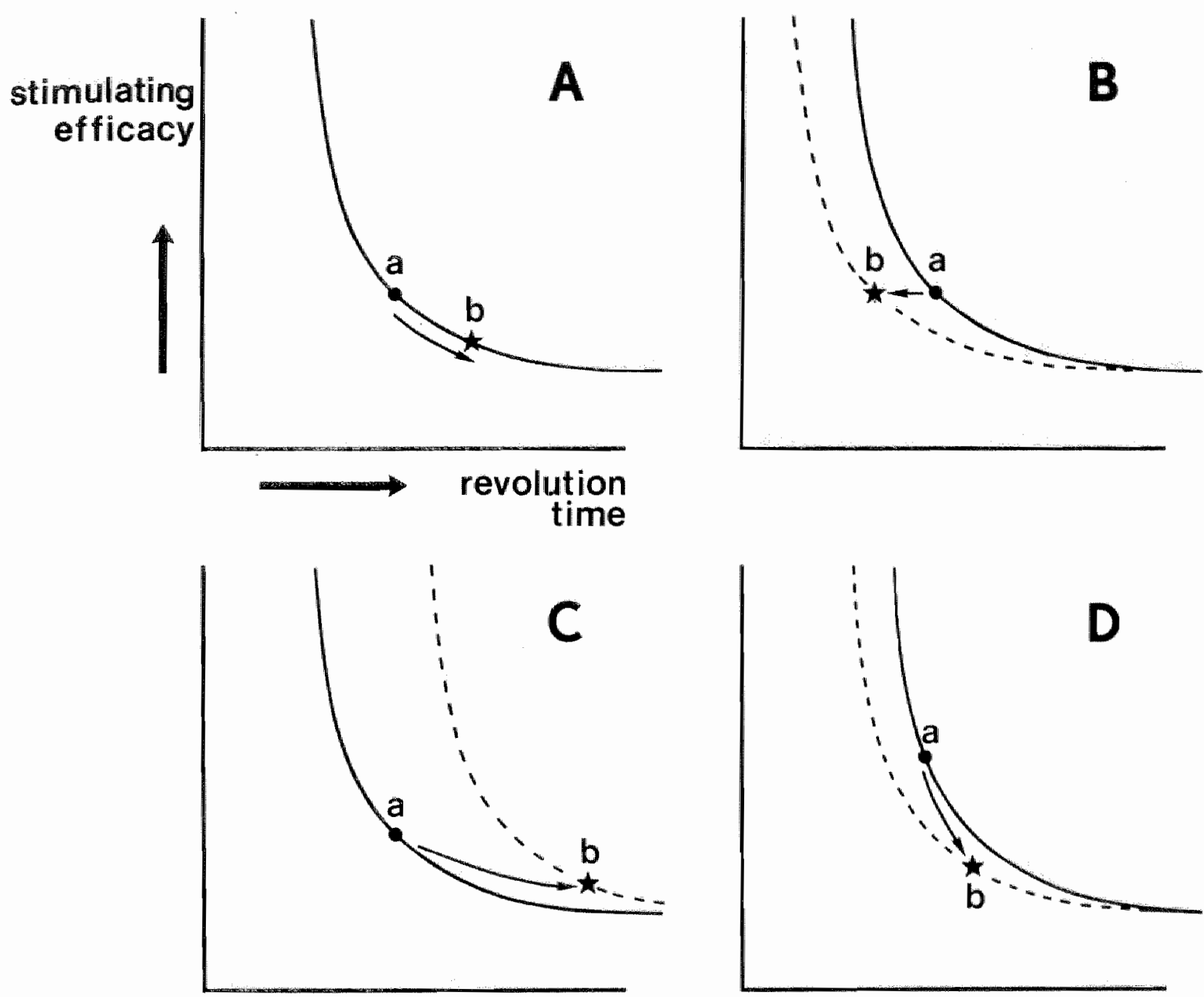

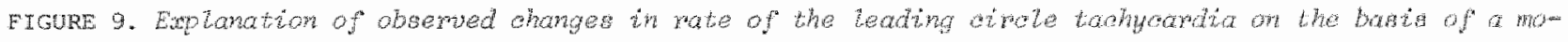

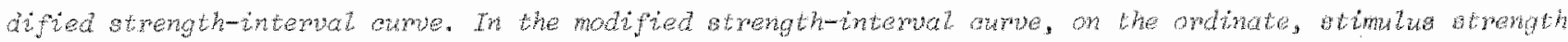

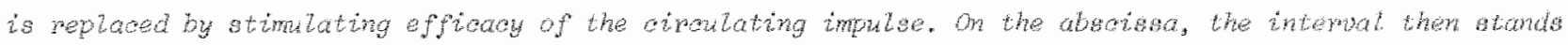
for mevolution time of the cincutating excitation.

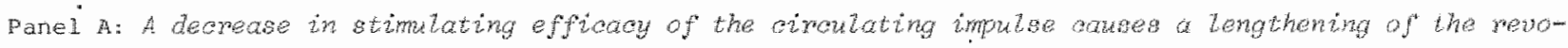

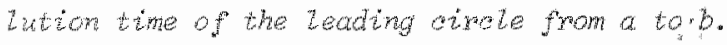

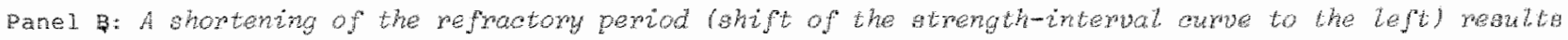
in a shorenting of the revolution time.

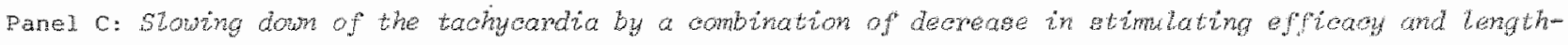
enting of the refractory period.

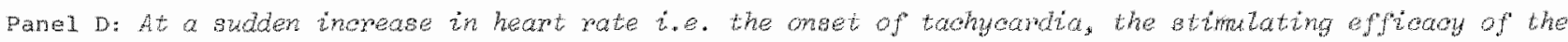

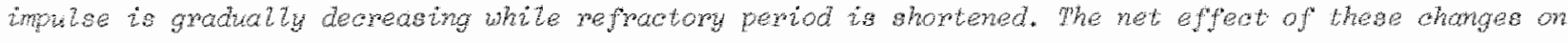

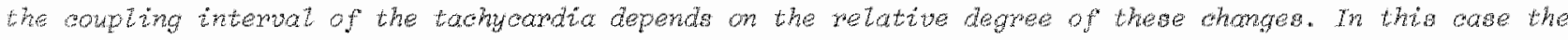
wet nesut was a levgthenting of the revolition time from a to b. 
However, a selective change elthex in stimulating efficacy or in refractory perioa is rarely met in nature. Most changes in electrophysiologic properties, occurring spontaneously or induced by certain cardiac drugs, affect both the upstroke of the action potential and the time course of restoration of excitability. In panels $C$ and $\dot{D}$ of figure 9 two examples of such a miscellaneous influence on the leading circle model are given. In panel $\mathrm{C}$ the combination of a decrease in stimulating efficacy and a lengthening of the refractory period is shown. Both the shift of the strength-interval curve to the right (broken line curve in panel c) and the decrease of the stimulating efficacy of the action potential coopexate to prolong the revolution time of the leading circle from $a$ to $b$. As a consequence the tachycardia will decelerate considerably. Since cooling of the heart exerts the above-mentioned combination of effects, we can take the temperature experiments for comparison (see fig 7). The relatively strong slowing of the tachycardia which we found to be associated with lowering of the temperature again seems to confirm the validity of the model. The same effect can be expected from cardiac arugs as quinjdine, procainamide and B-adrenergic blocking agents (8).

In other situations the changes in stimulating efficacy and refractory period will have an opposite effect on the interval of the tachycardia. An example of a situation in which a decrease in stimulating efficacy is coupled with a shortening of the refractory period is a sudden increase in heart rate. After a sudden increase in heart rate, amplitude and dV/at max of the action potential are gradually decreasing until only after a large number of beats (inundred or more) a new steady-state is reached 19,10$)$. At the same time the refractory period is gradually shortened (11). The sudden onset of a paroxysm of tachycardia thus is followed by a period in which the stimulating efficacy of the impulse gradually decreases while the refractory period is shortened. Whether as a result of these changes the cycle length of the tachycardia is gradually shortening (warming-up phenomenon) or lengthening, will depend on the degree to which both parameters are influenced. The paroxysms of tachycardia as produced experimentally in the isolated left atrium of the rabbit always showed a gradual increase in cycle length during its initial phase. As tachycardia progessed, cycle length becalme constant after about 100 beats (1). Panel D of figure 9 shows how this phenomenon can be explained on basis of the leading circle model. The solid curve represents the strength-interval curve during basic rhythm (interval $500 \mathrm{msec}$ ). The dotted line represents the strengthinterval curve after the tachycardia has reached a steady state (interval about 
$130 \mathrm{msecl}$. During the first 100 beats of the tachycardia the strength-interval curve is gradually shifting to this steady state value. At the same time the stimulating efficacy of the circulating wave front is gradually falling down. When, as in this example, the effect of the decrease of the stimulating efficacy on the revolution time exceeds the effect of the shortening of the refractory period, the net result will be a gradual lengthening of the interval of the tachycardia fxom $a$ to $b$. When on the othex hand the shortening of the refractory period is more marked, and the change in the upstroke of the action potential is moxe moderate, the net result can be opposite. After initiation of circus movement the revolution time will then get shorter, and the tachycardia will show the "warming-up" phenomenon.

Changes in dimensions of the leading circuit

The diameter of the leading circuit in the present experiments was about $6-8 \mathrm{~mm}$. This means that a minimal area of approximately $30-50 \mathrm{~mm}^{2}$ of atrial muscle is required to accommodate the circus movement. This in in remarkably good agreement with previous studies of West and Landa (12) who demonstrated that it is not possible to induce a sustained axxhythmia in rabbit atrial segments smaller than a critical mass of $30 \mathrm{mg}$. An important feature of the leading circle model is that the length of the reentrant pathway is determined by the electrophysiologido prom perties of the tissue. Changes in refractory period, conduction vellocity and stimulating efficacy will all influence the dinensions of the circult. An acceleration of the process of recovery of excitability shortehs the wave length of the circulating excitation. Since in the leading circle concept the length of the circular pathway equals the wave length of the impulse, a shortening of the refractory period will lead to a shortening of the circuit. The decrease in cycle length of tachycardias in intact pieces of atrial myocardium as observed after application of Carbamylcholine (see fig. 5) is therefore probably associated with a shortening of the circular pathway. Such a reduction of the dimensions for circus movement can also explain why Acetylcholine and its derivatives hiohly favour the induction and perpetuation of tachycardia (13) and why these drugs frequently convert tachycardia into fibrillation (14). Regarding fibrillation as a state in which more than one wavelet is circulating through the myocardium (15), the chance for the development of this situation is high, either in large hearts or in tissue in which small 
circuits are possible.

Finally we want to emphasize that the two different types of circulating excitation, as opposed in this paper, should be considered as extremes. In such a complex organ as the heart there is a good chance of intermingling of these forms of circus motement. If, instead of the presence, of a gross anatomic abstacle, there are pathways of preferential conduction, circus movement tachycardia may arise, which properties are somewhere in between the qualities of the leading circle model and cixcus movement in a large loop of cardiac tissue.

\section{ACKNOWLEDGEMENTS}

We gratefully acknowledge Prof. Dr. L.N. Bouman and Dr. T. Blange for the long hours of inspiring discussion during this study and Bebby van der Mars for secretarti help.

\section{REFERENCES}

1. Allessie, M.A., Bonke, F.I.M. and Schopman, F.J.G.: Circus movement in rabbit atrial muscle as a mechanism of tachycardia. Circ. Res. 33: 54-62, 1973.

2. Allessie, M.A., Bonke, F.I.M. and Schopman, F.J.G.: Circus movement in rabbit atrial muscle as a mechanism of tachycardia. II. The role of nonuniform recovery of excitability in the occurrence of unidirectional block, as studied with multiple microejectrodes. Circ. Res. 39: 168-177, 1976.

3. Mines, G.R.: on dynamic equilibrium in the heart. I. Physiol. (Lond). 46: $349-383,1913$.

4. Schreurs, A.W., Selij, A.P.I., Allessie, M.A. and Bonke, F.I.M.: A concentrically and radially adjustable holder for ten microelectrodes. Pfluegers Arch. 346: $167-179,1974$.

5. Yamagishi, S. and Sano, T.: Effect of temperature on pacemaker activity of rabbit sinus node. Am. J. Physiol. 212: 829-834, 1967.

6. Allessie, M.A., Van den Bergh, F.A., Bouman, I.N.: Temperature and frequency dependency of the atrial depolarisation. Pfluegers Arch. 318: 260, 1970.

7. Lewis, T.: The mechanism and graphic registration of the heart beat. London: Shaw and sons Ltd., $3^{\text {rd }}$ edition, 1925. 
8. Moe, G.K. and Abildskov, J.A.: Antiarrhythmic drugs. In: The Pharmacological Basis of Therapeutics, pp. 709-727. (Goodman, L.S. and Gilman, A. eds.). The MacMillan Company, New York, 1970.

9. Viersma, J.W., Bouman, L.N. and Matex. M.: Frequency, conduction velocity and rate of depolarization in rabbit auricle. Nature, 217: 1176-1177, 1968.

10. Pasmooij, J.H., van Enst, G.C., Bouman, L.N., Allessie, M.A. and Bonke, F.I.M.: The effect of heart rate on the membrane responsiveness of rabbit atrial muscle. Pfluegers Arch. 366: 223-231, 1976."

11. Janse, M.J., van der Steen, A.B.M., van Dam, R.rh., Durrer, D.: Refractory period of the dog's ventricular myocardium following sudden changes in frequency. Cixc. Res. 24: 251-261, 1969.

12. West, T.C. and Landa, J.F.: Minimal mass required for induction of a sustained arrhythmia in isolated atrial segments. Am. J. Physiol. 202: 232-236, 1962.

13. Winterberg, H.: Studien über Herzfimmern. I. Mitteilung. Über die Wirkung des $N$. vagus und accelerans auf das Flimmern des Herzens. PfJuegers Arch. 117: $223-256,1907$.

14. Lewis, T., Drury, A.N. and Bulger, H.A.: Observations upon flutter and fibrillation. Part VII. The effects of vagal stimulation. Heart, 8: 141-170, 1921.

15. Moe, G.K.: On the multiple wavelet hypothesis of atrial fibrillation. Arch. Intern. Pharmacodyn. Thes. 140: 183-188, 1962. 